\title{
\#USGS
}

Prepared in cooperation with Gwinnett County Department of Water Resources

\section{Hydrology and Water Quality in 13 Watersheds in Gwinnett County, Georgia, 2001-15}

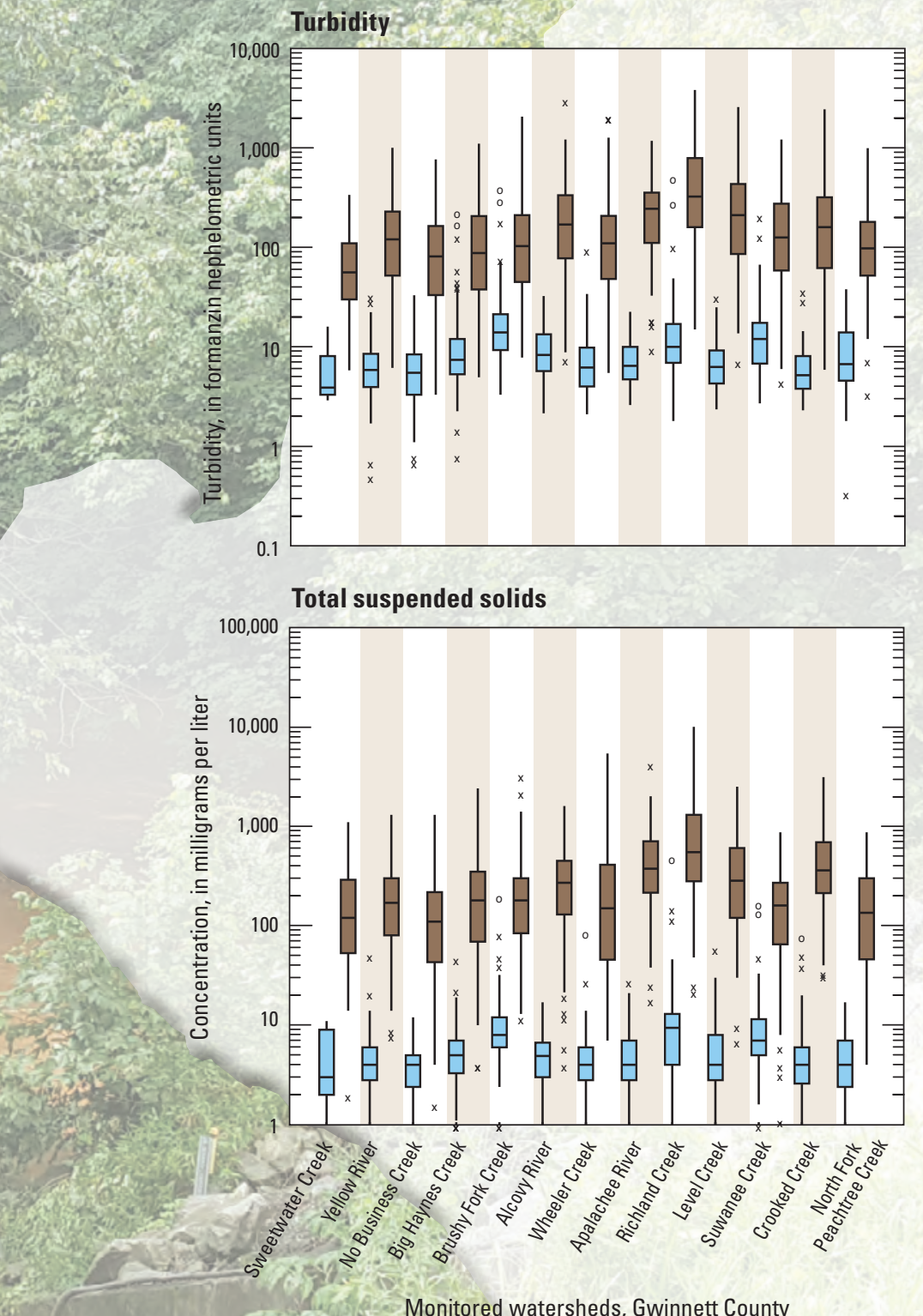

Scientific Investigations Report 2017-5012

U.S. Department of the Interior

U.S. Geological Survey 
Cover. Background image shows multiparameter monitoring station at Richland Creek at Suwanee Dam Road, near Buford, Georgia, looking upstream. Photograph by Kerry Caslow, USGS. See figure 26 of this report for details about turbidity and total suspended solids boxplots. 


\section{Hydrology and Water Quality in 13 Watersheds in Gwinnett County, Georgia, 2001-15}

By Brent T. Aulenbach, John K. Joiner, and Jaime A. Painter

Prepared in cooperation with Gwinnett County Department of Water Resources

Scientific Investigations Report 2017-5012 


\title{
U.S. Geological Survey William H. Werkheiser, Acting Director
}

\author{
U.S. Geological Survey, Reston, Virginia: 2017
}

For more information on the USGS - the Federal source for science about the Earth, its natural and living resources, natural hazards, and the environment—visit http://www.usgs.gov or call 1-888-ASK-USGS.

For an overview of USGS information products, including maps, imagery, and publications, visit http://store.usgs.gov/.

Any use of trade, firm, or product names is for descriptive purposes only and does not imply endorsement by the U.S. Government.

Although this information product, for the most part, is in the public domain, it also may contain copyrighted materials as noted in the text. Permission to reproduce copyrighted items must be secured from the copyright owner.

Suggested citation:

Aulenbach, B.T., Joiner, J.K., and Painter, J.A., 2017, Hydrology and water quality in 13 watersheds in Gwinnett County, Georgia, 2001-15: U.S. Geological Survey Scientific Investigations Report 2017-5012, 82 p., https://doi.org/10.3133/ sir20175012.

ISSN 2328-031X (print)

ISSN 2328-0328 (online)

ISBN 978-1-4113-4128-9 


\section{Contents}

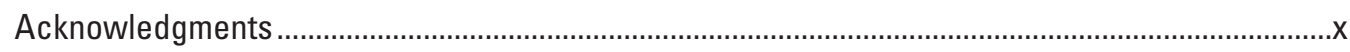

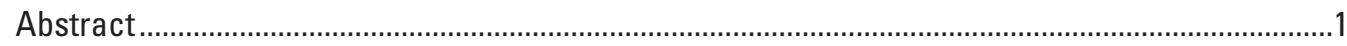

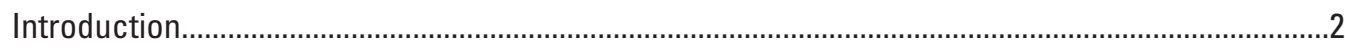

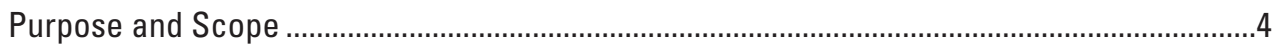

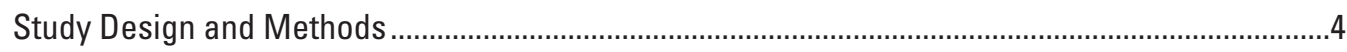

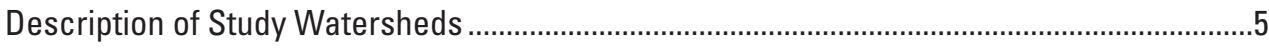

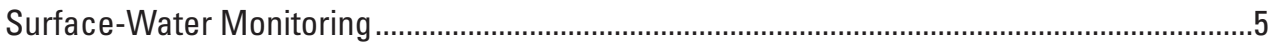

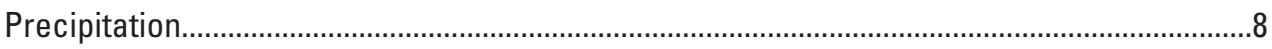

Identification of Surface-Water Constituent Concentration Long-Term Trends ......................8

Constituent Load Estimation .................................................................................................. 10

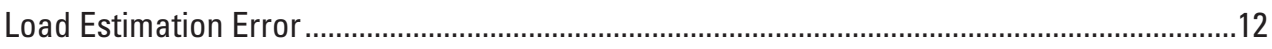

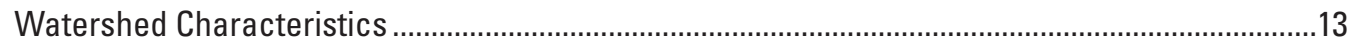

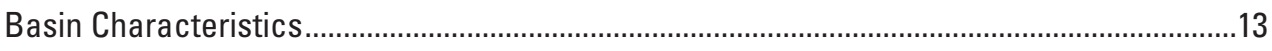

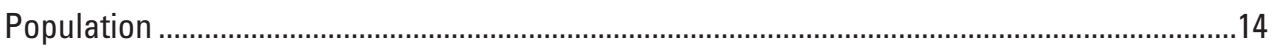

Land Use and Changes in Impervious Area ......................................................................20

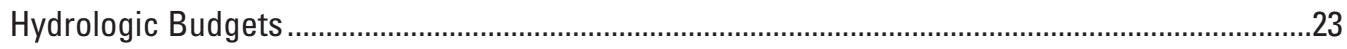

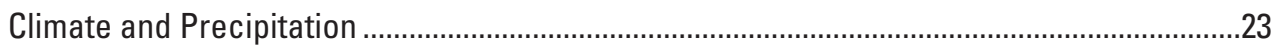

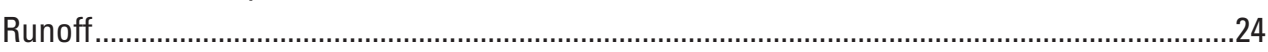

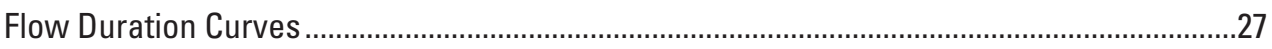

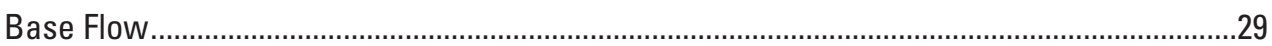

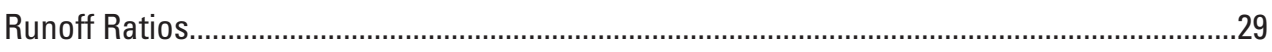

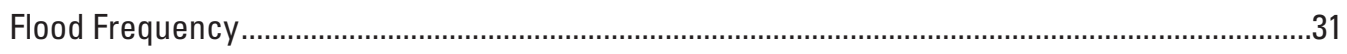

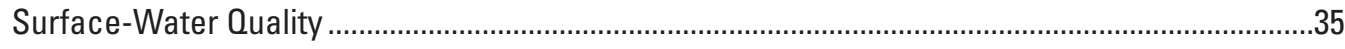

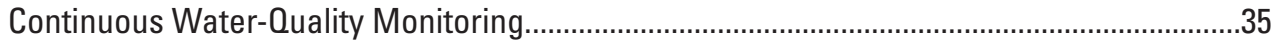

Base-Flow and Stormflow Water Quality ......................................................................................35

Water-Quality Seasonality and Long-Term Trends ........................................................................... 41

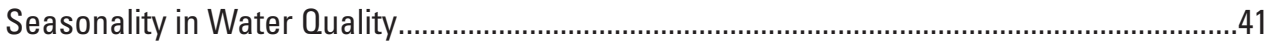

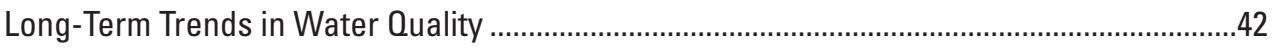

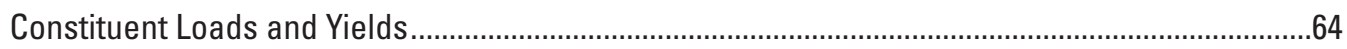

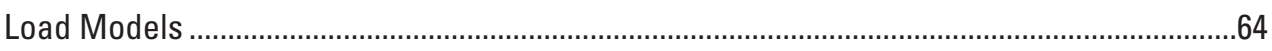

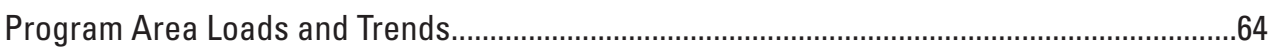

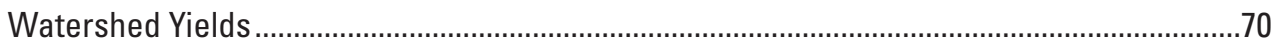

Differences with Previous Load Estimates..............................................................................74

Uncertainty in Load Estimates ................................................................................................... 74

Interpreting Aggregate Effects on Water Quality...........................................................................75

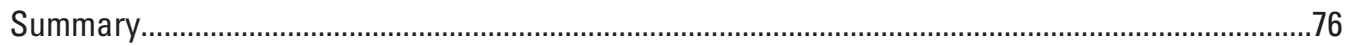

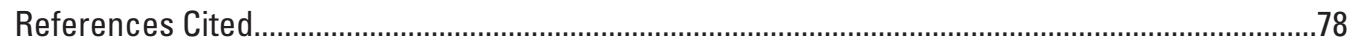




\section{Figures}

1. Map showing location of the study area and the 13 monitored watersheds and water-quality and precipitation monitoring stations, Gwinnett County, Georgia..

2. Photograph showing multiparameter monitoring station at Richland Creek at Suwanee Dam Road, near Buford, Georgia, looking upstream

3. Map showing land-surface altitude for Gwinnett County, Georgia ..

4. Graph showing average basin slope of the 13 monitored watersheds in Gwinnett County, Georgia.

5. Map showing land-surface slope for Gwinnett County, Georgia

6. Graphs showing total population by year and population growth for Gwinnett County, Georgia, 2001-15

7. Graph showing annual change in population for Gwinnett County, Georgia, from 2001 to 2015.

8. Map showing population density for Gwinnett County, Georgia, 2013.

9. Graph showing population density for the 13 monitored watersheds in Gwinnett County, Georgia, in 2009 and 2013.

10. Graph showing percentage of watershed impervious area from transportation and building land use for 13 monitored watersheds in Gwinnett County, Georgia, 2012

11. Graphs showing watershed impervious area as related to high-density land use and population density for 13 monitored watersheds in Gwinnett County, Georgia, 2013

12. Graph showing percentage of impervious area in 13 monitored watersheds in Gwinnett County, Georgia

13. Graph showing annual precipitation totals for each of the 13 monitored watersheds in Gwinnett County, Georgia, for water years 2002-15

14. Graph showing monthly average precipitation for each of the 13 monitored watersheds in Gwinnett County, Georgia, for water years 2002-15

15. Graph showing annual runoff for each of the 13 monitored watersheds in Gwinnett County, Georgia, for water years 2002-15.

16. Graph showing weekly drought severity in Gwinnett County, Georgia, for years 2001-15 as a portion of county area.

17. Graph showing average monthly runoff for each of the 13 monitored watersheds in Gwinnett County, Georgia, for water years 2002-15

18. Graph showing streamflow duration curves for each of the 13 monitored watersheds in Gwinnett County, Georgia, for water years 2002-15

19. Graph showing streamflow duration curves for the Yellow River watershed for wet, average, and dry years.

20. Graphs showing average base-flow runoff versus percentage of impervious area in 2008, and base-flow index versus percentage of impervious area in 2008 for 13 watersheds in Gwinnett County, Georgia, for water years 2002-15.

21. Graph showing annual runoff ratios for each of the 13 monitored watersheds in Gwinnett County, Georgia, for water years 2002-15.

22. Graph showing runoff ratios for water years $2002-15$ versus percentage of impervious areas in 2008 for each of the 13 monitored watersheds in Gwinnett County, Georgia..

23. Graph showing example of PeakFO probability graph of annual peaks, fitted frequency curve, and confidence limits for USGS station 02208050, Alcovy River near Lawrenceville, Georgia . 
24. Plot of stormflow response of specific conductance to streamflow for USGS station 02205865, Sweetwater Creek at Club Drive near Lilburn, Georgia, December 22-27, 2013

25. Plots of total suspended solids, suspended sediment, total lead, and total zinc sample concentrations versus turbidity for USGS station 02205865, Sweetwater Creek at Club Drive near Lilburn, Georgia

26. Boxplots of base-flow and stormflow sample concentrations for specific conductance, turbidity, total nitrogen, total ammonia plus organic nitrogen, total nitrate plus nitrite, total phosphorus, dissolved phosphorus, total organic carbon, total suspended solids, suspended sediment, total lead, total zinc, and total dissolved solids at 13 monitored watersheds in Gwinnett County.....

27. Graphs showing total nitrogen residuals to flow-only load estimation model versus time for 13 monitored watersheds in Gwinnett County, Georgia.

28. Graphs showing total nitrate plus nitrite residuals to flow-only load estimation model versus time for 13 monitored watersheds in Gwinnett County, Georgia

29. Graphs showing total phosphorus residuals to flow-only load estimation model versus time for 13 monitored watersheds in Gwinnett County, Georgia.

30. Graphs showing dissolved phosphorus residuals to flow-only load estimation model versus time for 13 monitored watersheds in Gwinnett County, Georgia

31. Graphs showing total organic carbon residuals to flow-only load estimation model versus time for 13 monitored watersheds in Gwinnett County, Georgia

32. Graphs showing total suspended-solid residuals to flow-only load estimation model versus time for 13 monitored watersheds in Gwinnett County, Georgia

33. Graphs showing suspended-sediment residuals to flow-only load estimation model versus time for 13 monitored watersheds in Gwinnett County, Georgia

34. Graphs showing total lead residuals to flow-only load estimation model versus time for 13 monitored watersheds in Gwinnett County, Georgia.

35. Graphs showing total zinc residuals to flow-only load estimation model versus time for 13 monitored watersheds in Gwinnett County, Georgia

36. Graphs showing total dissolved solids residuals to flow-only load estimation model versus time for 13 monitored watersheds in Gwinnett County, Georgia

37. Graphs showing annual loads and annual runoff for water years 2003-15 for the LTTM program study area in Gwinnett County, Georgia

38. Graphs showing annual average concentrations and annual runoff for water years 2003-15 for the LTTM program study area in Gwinnett County, Georgia

39. Graph showing average suspended-sediment loads and average annual runoff for years with dry, average, and wet climatic conditions for water years 2003-15 for the LTTM program study area in Gwinnett County, Georgia

40. Graph showing average total nitrogen and total nitrate plus nitrite yields for 13 monitored watersheds in Gwinnett County, Georgia, for water years 2003-15.

41. Graph showing average total and dissolved phosphorus yields for 13 monitored watersheds in Gwinnett County, Georgia, for water years 2003-15.

42. Graph showing average total organic carbon yields for 13 monitored watersheds in Gwinnett County, Georgia, for water years 2003-15

43. Graph showing average total suspended solids and suspended-sediment yields for 13 monitored watersheds in Gwinnett County, Georgia, for water years 2003-15.

44. Graph showing average total lead and total zinc yields for 13 monitored watersheds in Gwinnett County, Georgia, for water years 2003-15.

45. Graph showing average total dissolved solids yields for 13 monitored watersheds in Gwinnett County, Georgia, for water years 2003-15. 


\section{Tables}

1. Thirteen U.S. Geological Survey water-quantity and water-quality monitoring stations included in the watershed characteristics and water-quality trends study in Gwinnett County, Georgia, including dates established and drainage areas for each station

2. Water-quality constituents measured and analyzed for samples collected in streams in Gwinnett County, Georgia, units of measures, and predominant laboratory reporting limit

3. Summary of analytical methods used to quantify water-quality constituent concentrations of samples in streams in Gwinnett County, Georgia

4. Precipitation gages included in the study, including dates established and decommissioned, Gwinnett County, Georgia

5. Watershed characteristics for 13 watersheds in Gwinnett County, Georgia

6. Land use and watershed impervious area for 13 watersheds in Gwinnett County, Georgia, 2012

7. Average base-flow runoff and base-flow index for 13 watersheds in Gwinnett County, Georgia, for water years 2002-15.

8. Historical terminology associated with flood-frequency estimates and corresponding annual exceedance probability and P-percent chance exceedance

9. Annual exceedance probability discharges estimated from 13 stations in the LTTM program study area, Gwinnett County, Georgia ....

10. Summary of seasonal variability in 10 water-quality constituents at the 13 LTTM program watersheds in Gwinnett County, Georgia, based on the seasonality terms in the flow-only load estimation models

11. Water-quality constituent trends and statistical significance for sample concentrations in 13 monitored watersheds in Gwinnett County, Georgia, for water years 2001-15

12. Runoff and water-quality constituent load averages, annual minimum, annual maximum, trends, and trend statistical significance for water years 2003-15 for the LTTM program study area, Gwinnett County, Georgia. 


\section{Conversion Factors}

U.S. customary units to International System of Units

\begin{tabular}{|c|c|c|}
\hline Multiply & By & To obtain \\
\hline \multicolumn{3}{|c|}{ Length } \\
\hline inch (in.) & 2.54 & centimeter $(\mathrm{cm})$ \\
\hline inch (in.) & 25.4 & millimeter $(\mathrm{mm})$ \\
\hline foot $(\mathrm{ft})$ & 0.3048 & meter $(\mathrm{m})$ \\
\hline mile (mi) & 1.609 & kilometer (km) \\
\hline \multicolumn{3}{|c|}{ Area } \\
\hline acre & 0.4047 & hectare (ha) \\
\hline acre & 0.004047 & square kilometer $\left(\mathrm{km}^{2}\right)$ \\
\hline square mile $\left(\mathrm{mi}^{2}\right)$ & 259.0 & hectare (ha) \\
\hline square mile $\left(\mathrm{mi}^{2}\right)$ & 2.590 & square kilometer $\left(\mathrm{km}^{2}\right)$ \\
\hline \multicolumn{3}{|c|}{ Volume } \\
\hline million gallons (Mgal) & 3,785 & cubic meter $\left(\mathrm{m}^{3}\right)$ \\
\hline \multicolumn{3}{|c|}{ Flow rate } \\
\hline cubic foot per second $\left(\mathrm{ft}^{3} / \mathrm{s}\right)$ & 0.02832 & cubic meter per second $\left(\mathrm{m}^{3} / \mathrm{s}\right)$ \\
\hline million gallons per day $(\mathrm{Mgal} / \mathrm{d})$ & 0.04381 & cubic meter per second $\left(\mathrm{m}^{3} / \mathrm{s}\right)$ \\
\hline \multicolumn{3}{|c|}{ Mass } \\
\hline pound, avoirdupois (lb) & 0.4536 & kilogram (kg) \\
\hline
\end{tabular}

Temperature in degrees Celsius $\left({ }^{\circ} \mathrm{C}\right)$ may be converted to degrees Fahrenheit $\left({ }^{\circ} \mathrm{F}\right)$ as follows:

$$
{ }^{\circ} \mathrm{F}=\left(1.8 \times{ }^{\circ} \mathrm{C}\right)+32 \text {. }
$$

Temperature in degrees Fahrenheit $\left({ }^{\circ} \mathrm{F}\right)$ may be converted to degrees Celsius $\left({ }^{\circ} \mathrm{C}\right)$ as follows:

$$
{ }^{\circ} \mathrm{C}=\left({ }^{\circ} \mathrm{F}-32\right) / 1.8 \text {. }
$$

\section{Datum}

Vertical coordinate information is referenced to the North American Vertical Datum of 1988 (NAVD 88).

Altitude, as used in this report, refers to distance above the vertical datum.

\section{Supplemental Information}

Specific conductance (SC) is given in microsiemens per centimeter at 25 degrees Celsius $\left(\mu \mathrm{S} / \mathrm{cm}\right.$ at $\left.25^{\circ} \mathrm{C}\right)$.

Concentrations of chemical constituents in water are given either in milligrams per liter (mg/L) or micrograms per liter $(\mu \mathrm{g} / \mathrm{L})$.

A water year is the period from 0ctober 1 to September 30 and is designated by the year in which the period ends. 


\section{Abbreviations}

\begin{tabular}{|c|c|}
\hline${ }^{\circ} \mathrm{F}$ & degree Fahrenheit \\
\hline AEP & Annual Exceedance Probability \\
\hline AMLE & adjusted maximum likelihood estimate \\
\hline $\mathrm{BFI}$ & base-flow index \\
\hline BMP & best management practice \\
\hline C & constituent concentration \\
\hline $\mathrm{Cl}$ & confidence interval \\
\hline DP & dissolved phosphorus \\
\hline dtime & decimal time \\
\hline EMA & Expected Moments Algorithm \\
\hline ET & evapotranspiration \\
\hline EWI & equal-width increment \\
\hline FNU & Formazin Nephelometric Unit \\
\hline in/yr & inch per year \\
\hline LAD & least absolute deviation \\
\hline lb/acre/yr & pound per acre per year \\
\hline $\mathrm{lb} / \mathrm{d} / \mathrm{yr}$ & pound per day per year \\
\hline lidar & light detection and ranging \\
\hline LRL & laboratory reporting limit \\
\hline LT-MDL & long-term method detection level \\
\hline LTTM & Long-Term Trend Monitoring \\
\hline MNGWPD & Metropolitan North Georgia Water Planning District \\
\hline NAVD 88 & North American Vertical Datum of 1988 \\
\hline $\mathrm{NO}_{3}+\mathrm{NO}_{2}$ & total nitrate plus nitrite \\
\hline NPDES & National Pollutant Discharge Elimination System \\
\hline NWIS & National Water Information System \\
\hline $\mathrm{Pb}$ & total lead \\
\hline PET & potential evapotranspiration \\
\hline $\mathrm{R}^{2}$ & coefficient of multiple determination \\
\hline SC & specific conductance \\
\hline SE & standard error \\
\hline SEP & standard error of the prediction \\
\hline SSC & suspended-sediment concentration \\
\hline TDS & total dissolved solids \\
\hline
\end{tabular}


TKN total ammonia plus organic nitrogen (total Kjeldahl nitrogen)

TMDL total maximum daily load

TN total nitrogen

TOC total organic carbon

TP total phosphorus

TSS total suspended solids

USGS U.S. Geological Survey

WRTDS weighted regression on time, discharge, and season

WY water year

Zn total zinc 


\section{Acknowledgments}

The authors wish to thank personnel of Gwinnett County Department of Water Resources for their long-term commitment to improved data and understanding of water quality in the watersheds in their area.

This report is possible because of the field data-collection efforts and analysis expertise of the U.S. Geological Survey, Gwinnett Project personnel Kerry Caslow, Jonathan Evans, and numerous other USGS employees in the data section. Thanks are also extended to U.S. Geological Survey employees Jonathan Musser for GIS support, Anthony Gotvald, Celeste Journey, and Jimmy Webber for technical reviews. 


\title{
Hydrology and Water Quality in 13 Watersheds in Gwinnett County, Georgia, 2001-15
}

\author{
By Brent T. Aulenbach, John K. Joiner, and Jaime A. Painter
}

\section{Abstract}

The U.S. Geological Survey (USGS), in cooperation with Gwinnett County Department of Water Resources, established a Long-Term Trend Monitoring (LTTM) program in 1996. The LTTM program is a comprehensive, long-term, water-quantity and water-quality monitoring program designed to document and analyze the hydrologic and water-quality conditions of selected watersheds in Gwinnett County, Georgia. Water-quality monitoring initially began in six watersheds and currently [2016] includes 13 watersheds.

As part of the LTTM program, streamflow, precipitation, water temperature, specific conductance, and turbidity were measured every 15 minutes for water years $2001-15$ at 12 of the 13 watershed monitoring stations and for water years 2010-15 at the other watershed. In addition, discrete waterquality samples were collected seasonally from May through October (summer) and November through April (winter), including one base-flow and three stormflow event composite samples, during the study period. Samples were analyzed for nutrients (nitrogen and phosphorus), total organic carbon, trace elements (total lead and total zinc), total dissolved solids, and total suspended sediment (total suspended solids and suspended-sediment concentrations). The sampling scheme was designed to identify variations in water quality both hydrologically and seasonally.

The 13 watersheds were characterized for basin slope, population density, land use for 2012, and the percentage of impervious area from 2000 to 2014. Several droughts occurred during the study period-water years 2002, 2007-08, and 2011-12. Watersheds with the highest percentage of impervious areas had the highest runoff ratios, which is the portion of precipitation that occurs as runoff. Watershed base-flow indexes, the ratio of base-flow runoff to total runoff, were inversely correlated with watershed impervious area.

Flood-frequency estimates were computed for 13 streamgages in the study area that have 10 or more years of annual peak flow data through water year 2015, using the expected moments algorithm to fit a Pearson
Type III distribution to logarithms of annual peak flows. Kendall's tau nonparametric test was used to determine the statistical significance of trends in the annual peak flows, with none of the 13 streamgages exhibiting significant trends.

A comparison of base-flow and stormflow water-quality samples indicates that turbidity and concentrations of total ammonia plus organic nitrogen, total nitrogen, total phosphorus, total organic carbon, total lead, total zinc, total suspended solids, and suspended-sediment concentrations increased with increasing discharge at all watersheds. Specific conductance decreased during stormflow at all watersheds, and total dissolved solids concentrations decreased during stormflow at a few of the watersheds. Total suspended solids and suspended-sediment concentrations typically were two orders of magnitude higher in stormflow samples, turbidities were about 1.5 orders of magnitude higher, total phosphorus and total zinc were about one order of magnitude higher, and total ammonia plus organic nitrogen, total nitrogen, total organic carbon, and total lead were about twofold higher than in base-flow samples.

Seasonality and long-term trends were identified for the period water years 2001-15 for 10 constituents - total nitrogen, total nitrate plus nitrite, total phosphorus, dissolved phosphorus, total organic carbon, total suspended solids, suspended-sediment concentration, total lead, total zinc, and total dissolved solids. Seasonal patterns were present in most watersheds for all constituents except total dissolved solids, and the watersheds had fairly similar patterns of higher concentrations in the summer and lower concentrations in the winter. A linear long-term trend analysis of residual concentrations from the flow-only load estimation model (without time-trend terms) identified significant trends in 67 of the 130 constituent-watershed combinations. Seventy percent of the significant trends were negative. Total organic carbon and total dissolved solids had predominantly positive trends. Total phosphorus, total suspended solids, suspendedsediment concentration, total lead, and total zinc had only negative trends. The other three constituents exhibited fewer trends, both positive and negative. 
Streamwater loads were estimated annually for the 13-year period water years $2003-15$ for the same 10 constituents in the trend analysis. Loads were estimated using a regression-model-based approach developed by the USGS for the Gwinnett County LTTM program that accommodates the use of storm-event composited samples. Concentrations were modeled as a function of discharge, base flow, time, season, and turbidity to improve model predictions and reduce errors in load estimates. Total suspended solids annual loads have been identified in Gwinnett County's Watershed Protection Plan for target performance criterion.

Although the amount of annual runoff was the primary factor in variations in annual loads, climatic conditions (classified as dry, average, or wet) affected annual loads beyond what was attributed to climatic-related variations in annual runoff. Significant negative trends in loads were estimated for the combined area of the watersheds for all constituents except dissolved phosphorus, total organic carbon, and total dissolved solids. The trend analysis indicated that total suspended solids and suspended-sediment concentration loads in the study area were decreasing by 57,000 and 87,000 pounds per day per year, respectively.

Variations in constituent yields between watersheds appeared to be related to various watershed characteristics. Suspended sediment (as either total suspended solids or suspended-sediment concentrations), along with constituents transported predominately in solid phase (total phosphorus, total organic carbon, total lead, and total zinc), and total dissolved solids typically had higher yields from watersheds that had high percentages of impervious areas or high basin slope. High total nitrogen yields were also associated with watersheds with high percentages of impervious areas. Low total nitrogen, total suspended solids, total lead, and total zinc yields appeared to be associated with watersheds that had a low percentage of high-density development.

\section{Introduction}

Surface-water quantity and quality reflect and integrate the effects of watershed characteristics, inputs from point and nonpoint source pollutants, and climatic variability. Changes in land use alter complex interactions that affect many processes within a watershed (MacDonald, 2000). Urbanization, with its associated increases in impervious area, has been determined to be an important factor affecting the rainfall-runoff relations in many studies (for example, Hollis, 1975; Ogden and others, 2011), including studies of areas in Gwinnett County (Landers and others, 2007). Impervious areas affect hydrologic response by (1) decreasing rainfall infiltration and groundwater recharge rates, resulting in lower stream base flow, and (2) increasing storm runoff, peak discharges, and flood flows (Leopold, 1968). High peak storm streamflows can affect surface-water quality by increasing surface erosion, sediment transport, and pollutant loadings and by altering stream-channel stability. Groundwater storage and stream base-flow levels can be critically important during droughts in providing water for human activities and promoting healthy ecosystems (for example, Poff and others, 1997; Swirepik and others, 2016). Many studies have also shown that the effects of urbanization on the flow regime may decrease stream biological richness (for example, DeGasperi and others, 2009) and that native stream biota is best adapted to natural, unimpacted streamflows (Richter and others, 1996, 1997). Stormwater best management practices and other erosion controls are frequently implemented to mitigate the effects of urbanization on stream hydrology and minimize sediment transport in urbanized areas. Long-term monitoring of specific water-quality constituents allows for the identification of trends and the computation of loads and yields. Variations and trends in water quality can then be attributed to climatic variability, changes in land use and contaminant inputs, and potentially lead to implementation of watershed management strategies.

Gwinnett County has undergone rapid population growth since 1980, and land use has changed from what was once predominantly agriculture and forest to a highly developed area. The U.S. Geological Survey (USGS), in cooperation with Gwinnett County Department of Water Resources, established a comprehensive Long-Term Trend Monitoring (LTTM) program in 1996 to monitor, analyze, and quantify the magnitudes of pollutants and the effects of urbanization on six watersheds. Six additional watersheds were added to the LTTM program in 2001, and a 13th watershed was added in 2010 (fig. 1). These 13 watersheds were continuously monitored for water level (stage), precipitation, water temperature, specific conductance (SC), and turbidity at 15-minute intervals. Three stormflow-composited samples and one base-flow sample were collected in summer (May-October) and winter (November-April) of each year for a total of eight samples a year; samples were analyzed for nutrients, total recoverable trace metals, total dissolved solids, and total suspended sediment (total suspended solids and suspended-sediment concentration). The sampling scheme was designed to identify variations in water quality both hydrologically and seasonally.

The primary purpose of the monitoring program is to collect consistent, high-quality water-quantity and waterquality data and determine the status and trends in both stream runoff and water quality. Watershed managers can use these data to make informed management decisions in order to maintain the designated uses of streams, protect aquatic habitats, and optimize the effectiveness of best management practices (BMPs). Gwinnett County has adopted a stormwater management plan (Gwinnett County Department of Planning and Development, 2006) to mitigate the effects of increased impervious area on storm runoff and water quality. This plan has resulted in the widespread implementation of structural BMPs consisting mostly of wet, dry, and dry-extended detention ponds and constructed wetlands (Gwinnett County Department of Planning and Development, unpub. database, 2010). Intensive, long-term monitoring of watershed characteristics, streamflow, and stream quality are essential 

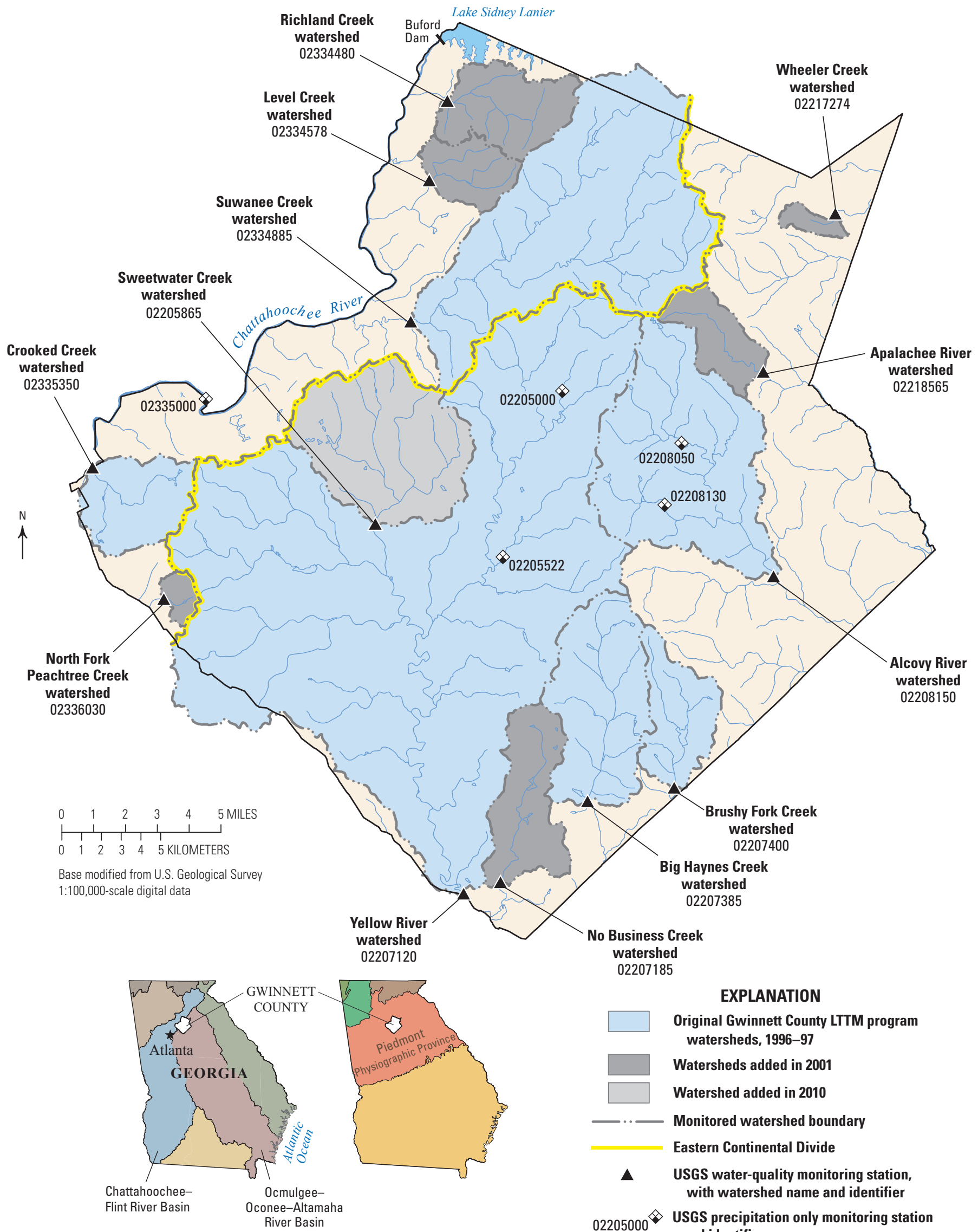

EXPLANATION

Original Gwinnett County LTTM program watersheds, 1996-97

Watersheds added in 2001

Watershed added in 2010

Monitored watershed boundary

Eastern Continental Divide

USGS water-quality monitoring station, with watershed name and identifier

02205000 USGS precipitation only monitoring station and identifier

Figure 1. Location of the study area and the 13 monitored watersheds and water-quality and precipitation monitoring stations, Gwinnett County, Georgia. 
to quantifying the effects of specific land uses, point-source and nonpoint-source discharges, and management practices on surface water (water quantity, flow characteristics, and water quality). The LTTM program also fulfills requirements outlined in the Gwinnett County Watershed Protection Plan (Gwinnett County Department of Public Utilities, 2000) as well as requirements for the National Pollutant Discharge Elimination System (NPDES) permit and the Metropolitan North Georgia Water Planning District (MNGWPD).

\section{Purpose and Scope}

The purpose of this report is to summarize and analyze the land-use, hydrologic, and water-quality data collected as part of Gwinnett County's LTTM program for 13 watersheds for the period water years (WYs) 2001-15. This report is an update to, and continuation of, the reports by Landers and others (2007), in which data for the original 6 watersheds were presented and analyzed for WYs 1996-2003, and by Joiner and others (2014), in which data for 12 watersheds were presented and analyzed for WYs 2004-09. The specific goals of this report are to

- Present watershed characteristics for the 13 watersheds and discuss changes and trends in population and impervious area;

- Report and discuss annual and monthly hydrologic inputs and outputs (precipitation and runoff) for WYs 2002-15;

- Calculate selected flood-frequency statistics for 13 streamgages in the study area that have 10 or more years of annual peak flow data through WY 2015;
- Summarize water-quality data for WYs 2001-15;

- Determine trends for 10 water-quality constituents (total nitrate plus nitrite, total nitrogen, total phosphorus, dissolved phosphorus, total organic carbon, total suspended solids, suspended sediment, total lead, total zinc, and total dissolved solids) for the period WYs 2001-15; and

- Provide annual load and yield estimates for 10 constituents (total nitrate plus nitrite, total nitrogen, total phosphorus, dissolved phosphorus, total organic carbon, total suspended solids, suspended sediment, total lead, total zinc, and total dissolved solids) for WYs 2003-15.

\section{Study Design and Methods}

Thirteen watersheds were monitored at their outlets for stage (water level), discharge, precipitation, and continuous water-quality constituents as part of the Gwinnett County LTTM program. A typical multiparameter stream monitoring station is shown in figure 2 . Water-quality samples were collected seasonally during base-flow and stormflow events and were measured or analyzed for 12 water-quality constituents, including field properties, nutrients, trace metals, suspended sediment, and total dissolved solids. Long-term trends were examined in sample concentrations for 10 waterquality constituents. Annual streamwater loads and yields, and their confidence intervals, were estimated for the 10 waterquality constituents.

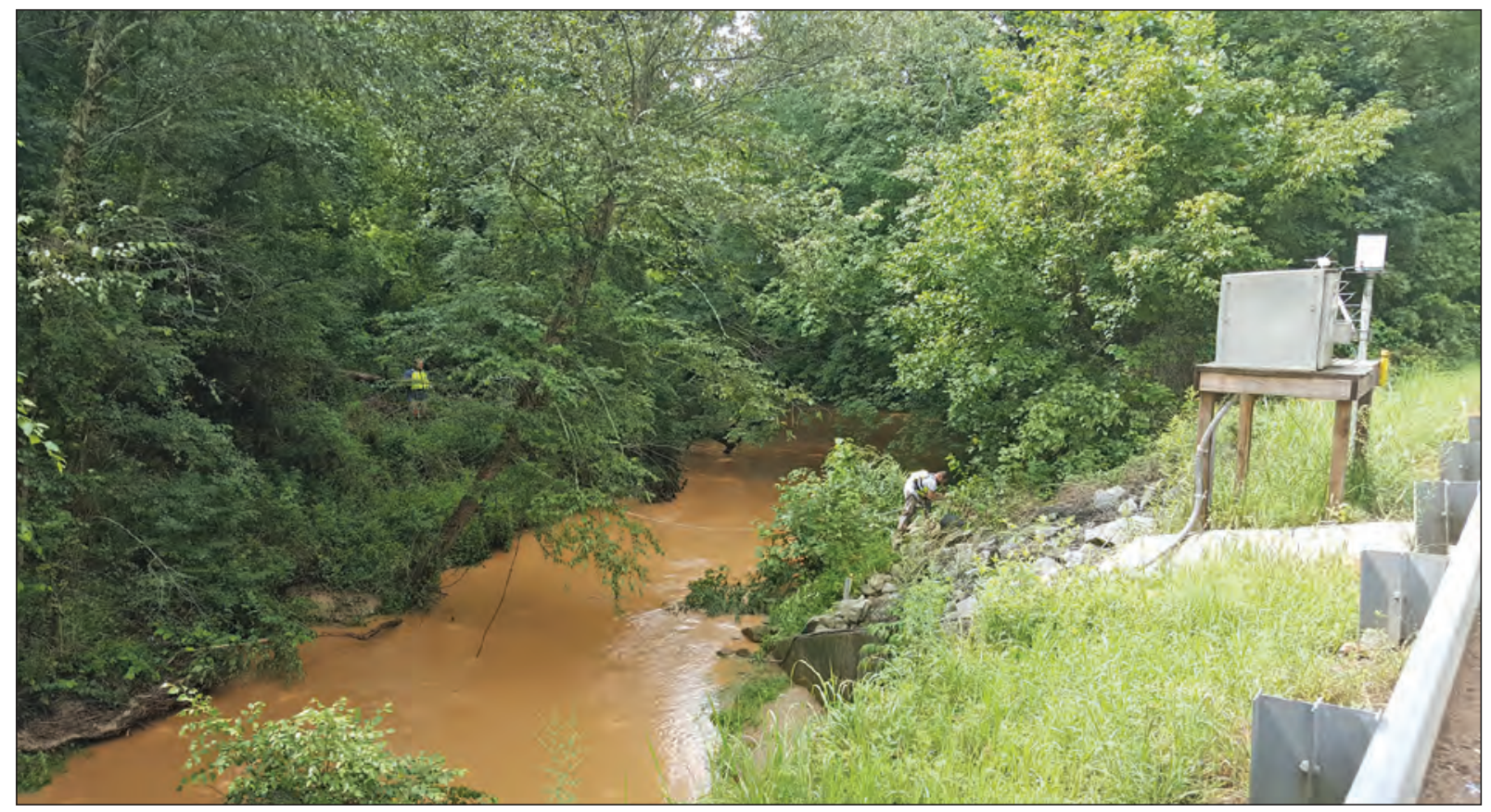

Figure 2. Multiparameter monitoring station at Richland Creek at Suwanee Dam Road, near Buford, Georgia (USGS station 02334480), looking upstream. USGS hydrologic technicians prepare to conduct a discharge measurement. Photograph by Kerry Caslow, USGS. 


\section{Description of Study Watersheds}

The 13 watersheds monitored as part of the Gwinnett County LTTM program are listed in table 1. Initially, six watersheds were monitored when the LTTM program started in 1996: (1) Brushy Fork Creek, (2) Alcovy River, (3) Big Haynes Creek, (4) Suwanee Creek, (5) Yellow River, and (6) Crooked Creek. In 2001, six additional watersheds were added to the LTTM program: (7) No Business Creek, (8) Wheeler Creek, (9) Apalachee River, (10) Richland Creek, (11) Level Creek, and (12) North Fork Peachtree Creek. In 2010, the (13) Sweetwater Creek watershed was added to the LTTM program. The Sweetwater Creek watershed lies within the monitored area of the Yellow River watershed and is the only "nested" watershed in the study (fig. 1). Program watersheds were selected to ensure diverse basin characteristics and land use for evaluating streamflow quantity and quality characteristics, while ensuring an appropriate spatial coverage of the county. The selected watersheds have variable waterquality attainment statuses (whether or not water-quality standards are met) and contain a diversity of point-source discharges. The specific monitoring station locations were determined on the basis of the suitability for hydrologic instrumentation and personnel safety. All stage, discharge, precipitation, and continuous and sample water-quality data used in this analysis are available from the USGS National Water Information System (NWIS) web interface at https://doi.org/10.5066/F7P55KJN using the USGS station numbers listed in tables 1 and 4 (U.S. Geological Survey, 2016).

\section{Surface-Water Monitoring}

The LTTM program follows standard USGS protocols for measuring stage, making streamflow measurements, and computing discharge (Rantz and others, 1982a, 1982b). Stage is recorded every 15 minutes to the nearest 0.01 foot and is routinely verified to an outside reference gage. This reference gage is periodically checked with surveying levels and other established reference marks to verify the gage vertical datum. Discharge measurements are made over a wide range of hydrologic conditions to develop a stage-discharge relation (rating curve) at each monitoring station used to compute discharge from the stage measurements. Discharge measurements were regularly made in order to continually refine the stage-discharge relation and to account for any temporal changes in the relation due to changes in the shape of the streambed. Streamflow for periods of missing stage data was estimated from relations in hydrograph data between the station with the missing data and nearby basins having similar characteristics (Rantz and others, 1982b).

Daily average streamflow data were not available for 33 high flow days in WYs 2002-03. High flow discharge measurements for the North Fork Peachtree Creek watershed were insufficient during that period to develop the rating curve to relate stage to discharge for high flows. In order to report annual and monthly runoff for these two WYs, streamflows for these days were estimated using rating curve 2.1 developed for WY 2004 that covered the range of stages observed in WYs 2002-03.

Table 1. Thirteen U.S. Geological Survey (USGS) water-quantity and water-quality monitoring stations included in the watershed characteristics and water-quality trends study in Gwinnett County, Georgia, including dates established and drainage areas for each station.

\begin{tabular}{lllc}
\hline $\begin{array}{c}\text { USGS station } \\
\text { number }\end{array}$ & \multicolumn{1}{c}{ Station name } & \multicolumn{1}{c}{ Date established } & $\begin{array}{c}\text { Drainage area } \\
\text { (square miles) }\end{array}$ \\
\hline 02205865 & Sweetwater Creek at Club Drive near Lilburn, Ga. & March 2010 & 21.0 \\
\hline 02207120 & Yellow River at Ga. Hwy 124 near Lithonia, Ga. & April 1996 & 161.4 \\
\hline 02207185 & No Business Creek at Lee Road, below Snellville, Ga. & March 2001 & 10.1 \\
\hline 02207385 & Big Haynes Creek at Lenora Road, near Snellville, Ga. & June 1996 & 17.3 \\
\hline 02207400 & Brushy Fork Creek at Beaver Road near Loganville, Ga. & June 1996 & 8.18 \\
\hline 02208150 & Alcovy River at New Hope Road, near Grayson, Ga. & June 1997 & 30.8 \\
\hline 02217274 & Wheeler Creek at Bill Cheek Road, near Auburn, Ga. & June 2001 & 1.31 \\
\hline 02218565 & Apalachee River at Fence Road, near Dacula, Ga. & July 2001 & 5.65 \\
\hline 02334480 & Richland Creek at Suwanee Dam Road, near Buford, Ga. & May 2001 & 9.37 \\
02334578 & Level Creek at Suwanee Dam Road, near Suwanee, Ga. & May 2001 & 5.06 \\
\hline 02334885 & Suwanee Creek at Suwanee, Ga. & September 1996 & 47.1 \\
\hline 02335350 & Crooked Creek near Norcross, Ga. & March 1996 & 8.87 \\
\hline 02336030 & North Fork Peachtree Creek at Graves Road, near Doraville, Ga. & June 2001 & 1.53 \\
\hline
\end{tabular}


Daily average streamflow was separated into base-flow and stormflow components for each watershed by hydrograph separation. This was done for the purposes of calculating the base-flow index of each watershed and for using base flow as a predictor variable of constituent concentrations. Hydrograph separations were done using the web-based Hydrograph Analysis Tool (https://engineering.purdue.edu/ what/, accessed May 18, 2016; Lim and others, 2005). The simple local minimum method was used, which required no parameters to be fit.

Continuous water-quality monitors were deployed in 2001 at each monitoring station to measure water temperature, $\mathrm{SC}$, and turbidity at 15 -minute intervals. These water-quality monitors typically are cleaned and their calibration checked every 2 weeks and more frequently following hydrologic events or after observing abnormal readings, which could be associated with fouling, instrument failure, or point sources or nonpoint sources of pollution. These water-quality monitors are maintained, and their corresponding sensor records are checked using the quality-assurance and quality-control procedures outlined in Wagner and others (2006).

All continuously monitored data (stage, precipitation, and water quality) are transmitted hourly by way of satellite communication and are available to the public from the USGS NWIS web interface (https://doi.org/10.5066/F7P55KJN) as values and time-series plots, which also can be accessed at http://waterdata.usgs.gov/ga/nwis/current/?type=flow\&group key=basin_cd (accessed January 17, 2017). Due to public interest in receiving the data in near real time during periods of extreme runoff, each station is designed to send emergency transmissions every 15 minutes during these periods. These transmissions occur when rainfall intensities exceed 2 inches per hour or when there are large rates of change in stage, as determined from thresholds defined for each station. The real-time data combined with the USGS WaterAlert tool (http://maps.waterdata.usgs.gov/mapper/wateralert/, accessed January 17, 2017), can be used as a flood warning system for emergency managers and the public.

Two discrete base-flow samples and six stormflow samples were collected each year at each of the 13 stations for water-quality analyses. The year is divided into two seasons, summer (May through October) and winter (November through April), with one base-flow sample and three stormflow samples collected during each season. Base-flow samples were collected using a USGS DH-81 manual sampler, using depth integrated, equal-width-increment (EWI) integrating techniques to ensure a representative sample as outlined in the National Field Manual for the Collection of Water-Quality Data (U.S. Geological Survey, 2006). When streamflow velocities fell below 1.5 feet per second (ft/s) during these baseflow conditions, these samples were considered multivertical grab samples; but at streamflow velocities above $1.5 \mathrm{ft} / \mathrm{s}$, these samples were considered true isokinetic samples. Base-flow samples were collected after no more than 0.1 inch of precipitation had fallen during the previous 72 hours. During base-flow sampling, a calibrated water-quality multiparameter sonde was used to concurrently measure the field properties of $\mathrm{SC}, \mathrm{pH}$, water temperature, dissolved oxygen, and turbidity in accordance with the Watershed Protection Plan for Gwinnett County (Gwinnett County Department of Public Utilities, 2000).

Stormflow sampling protocols required event precipitation to be a minimum of 0.3 inch. Additionally, a minimum of 72 hours is required between each event to ensure that the events are discrete and that the measured water-quality properties are associated with the sampled event. Stormflow samples were collected using automatic samplers that pump water from a designated point in the stream. The sampler is programmed to begin sampling when specified precipitation and (or) stage thresholds are reached. A single discharge-weighted composite sample is collected for each storm for water-quality analysis; samples are assumed to be representative of the constituent concentration variations that occur during an event. The composite sample is collected using the constant volume, time proportional to flow volume increment protocol (U.S. Environmental Protection Agency, 1992), in which a sample of equal volume is collected each time a specified volume of water flows by the station. Before each storm event, samplers are programmed for the volume of water to flow by the station between each sample aliquot, with the intent of sampling throughout the duration of the storm. This volume of water is determined from the storm's expected runoff response, which is estimated from previous storm responses to the predicted amount, duration, and intensity of the precipitation event during similar antecedent wetness conditions. The samplers were programed to collect either 14 one-liter or 25 half-liter aliquots during each storm. The average streamflow of the aliquots that make up the composite sample are stored for each sample record in the USGS NWIS database.

The automatic sampler tubing and intake are cleaned and prepared prior to each sampling event. The samples are refrigerated in the automatic sampler at about 4 degrees Celsius and are retrieved from the sampler within 24 hours of the end of an event. Sampler cleaning and maintenance procedures are further documented in the USGS field methods protocol (Wilde, 2004). Because automatic samplers collect samples from a single point in the stream cross section, periodic concurrent EWI and automatic samples are collected. These samples are independently analyzed and compared to ensure that the automatic point sample is representative of the entire stream cross section.

Base-flow and stormflow samples were processed and preserved following USGS field methods (Wilde and others, 2004). Samples were measured for specific conductance (SC) and turbidity and were analyzed for 10 constituents: nutrients (total nitrate plus nitrite $\left[\mathrm{NO}_{3}+\mathrm{NO}_{2}\right]$, total ammonia plus organic nitrogen [total Kjeldahl nitrogen, TKN], total phosphorus [TP], dissolved phosphorus [DP], and total organic carbon $[\mathrm{TOC}]$ ); suspended sediment (total suspended solids [TSS] and suspended-sediment concentrations [SSC]); 
trace metals (total lead $[\mathrm{Pb}]$ and total zinc $[\mathrm{Zn}]$ ); and total dissolved solids (TDS) in USGS laboratories in Denver, Colorado; Atlanta, Georgia; Louisville, Kentucky; and other USGS-approved laboratories (RTI Laboratories, Livonia, Michigan, and TestAmerica Laboratories, Inc., Arvada, Colorado). Total nitrogen (TN) was calculated as the sum of $\mathrm{NO}_{3}+\mathrm{NO}_{2}$ and TKN. Units of measurement and laboratory reporting limits (LRLs) for each constituent are listed in table 2. A censored value occurs when a concentration is below its long-term method detection level (LT-MDL) and is indicated by a remark code of " $<$ " with its concentration set to the LRL. For inorganic analyses, the LRL is set equal to its LT-MDL. For organic analyses, the LRL is set to twice the LT-MDL, with concentrations less than the LT-MDL indicated as censored values $(<)$, and values between the LT-MDL and the LRL indicated as an estimated concentration with a remark code of "e" (Childress and others, 1999). The LRLs for some constituents have changed over time due to changes in approved laboratory methods. The LRLs listed in table 2 are the predominant reporting limits observed and reflect the analytical methods used during WYs 2001-15. The percentages of censored concentrations are summarized by constituent in table 2. Analytical methods are listed in table 3. Several constituents that were included in the 1996-2003 period of LTTM program have been discontinued as of 2004: total cadmium, total chromium, total copper, biological oxygen demand, and chemical oxygen demand. Field waterquality blank and replicate samples were collected in compliance with USGS protocols (U.S. Geological Survey, 2006); laboratory analyses include an extensive quality-control and quality-assurance program.

Concentrations of suspended organic and inorganic particles in surface waters were quantified in this study using two different laboratory analytical methods - suspendedsediment concentrations (SSC) and total suspended solids (TSS; Gray and others, 2000). The SSC analytical method involves measuring the dry weight of the sediment in an entire sample of a known volume, and the TSS method involves measuring the dry weight of the sediment in a subsample of the available sample volume, rather than the entire sample (Landers, 2013). Whole-water samples were analyzed for SSC at the USGS Georgia Sediment Laboratory, in Atlanta, Georgia, and the USGS Kentucky Sediment Laboratory, in Louisville, Kentucky. Methods for processing SSC are described in Knott and others (1993) and Shreve and Downs (2005). The SSC analytical method is considered to produce more consistent results than the TSS method; however, the TSS method is often the method adopted for regulatory monitoring. Annual yield of TSS is the primary performance criterion for suspended sediment in Gwinnett County's Watershed Protection Plan (Gwinnett County Department of Public Utilities, 2000). Generally, a bias in relation to SSC and TSS is observed when sand-sized material are greater than 25 percent of the sediment dry weight, such that the SSC values tend to exceed their paired TSS values (Gray and others, 2000). This bias indicated TSS was a poor measure of suspended particles in stormwater when the dominant fraction was sand size or coarser.

Table 2. Water-quality constituents measured and analyzed for samples collected in streams in Gwinnett County, Georgia, units of measures, and predominant laboratory reporting limit.

[USGS, U.S. Geological Survey; na, not applicable. Units: ${ }^{\circ} \mathrm{C}$, degrees Celsius; FNU, Formazin Nephelometric Units; mg/L, milligram per liter; $\mu \mathrm{g} / \mathrm{L}$, microgram per liter; $\mu \mathrm{S} / \mathrm{cm}$, microsiemen per centimeter; C, carbon; $\mathrm{N}$, nitrogen; $\mathrm{P}$, phosphorus]

\begin{tabular}{|c|c|c|c|c|c|}
\hline $\begin{array}{c}\text { USGS } \\
\text { parameter } \\
\text { code }\end{array}$ & Constituent & $\begin{array}{l}\text { Constituent } \\
\text { abbreviation }\end{array}$ & Units & $\begin{array}{l}\text { Laboratory } \\
\text { reporting } \\
\text { limit }\end{array}$ & $\begin{array}{l}\text { Percentage } \\
\text { of censored } \\
\text { samples }\end{array}$ \\
\hline 00095 & Specific conductance & $\mathrm{SC}$ & $\mu \mathrm{S} / \mathrm{cm}$ at $25^{\circ} \mathrm{C}$ & na & na \\
\hline 63680 & Turbidity & na & FNU & na & na \\
\hline 00630 & Total nitrate plus nitrite & $\mathrm{NO}_{3}+\mathrm{NO}_{2}$ & $\mathrm{mg} / \mathrm{L}$ as $\mathrm{N}$ & 0.019 & 0.1 \\
\hline 00625 & Total ammonia plus organic nitrogen & TKN & $\mathrm{mg} / \mathrm{L}$ as $\mathrm{N}$ & 0.20 & 14.3 \\
\hline 00600 & Total nitrogen & $\mathrm{TN}$ & $\mathrm{mg} / \mathrm{L}$ as $\mathrm{N}$ & 0.22 & 14.3 \\
\hline 00665 & Total phosphorus & $\mathrm{TP}$ & $\mathrm{mg} / \mathrm{L}$ as $\mathrm{P}$ & ${ }^{1} 0.02$ & 13.4 \\
\hline 00666 & Dissolved phosphorus & $\mathrm{DP}$ & $\mathrm{mg} / \mathrm{L}$ as $\mathrm{P}$ & ${ }^{1} 0.02$ & 34.7 \\
\hline 00680 & Total organic carbon & TOC & $\mathrm{mg} / \mathrm{L}$ & 1.0 & 0.3 \\
\hline 00530 & Total suspended solids & TSS & $\mathrm{mg} / \mathrm{L}$ & 1.0 & 4.2 \\
\hline 80154 & Suspended sediment & $\mathrm{SSC}$ & $\mathrm{mg} / \mathrm{L}$ & 1.0 & 0.0 \\
\hline 01051 & Total lead & $\mathrm{Pb}$ & $\mu \mathrm{g} / \mathrm{L}$ & 1.0 & 26.4 \\
\hline 01092 & Total zinc & $\mathrm{Zn}$ & $\mu \mathrm{g} / \mathrm{L}$ & 2.0 & 3.1 \\
\hline 70300 & Total dissolved solids & TDS & $\mathrm{mg} / \mathrm{L}$ & 5.0 & 0.0 \\
\hline
\end{tabular}

${ }^{1} 0.02 \mathrm{mg} / \mathrm{L}$ as P prior to and including July 2004 ; typically $<0.05 \mathrm{mg} / \mathrm{L}$ as P August 2004-December 2006; typically $<0.005 \mathrm{mg} / \mathrm{L}$ as $\mathrm{P}$ after December 2006. 
Table 3. Summary of analytical methods used to quantify water-quality constituent concentrations of samples in streams in Gwinnett County, Georgia.

[EPA, U.S. Environmental Protection Agency; ${ }^{\circ} \mathrm{C}$, degree Celsius]

\begin{tabular}{|c|c|c|}
\hline Constituent & Method & Reference \\
\hline Total nitrate plus nitrite & $\begin{array}{l}\text { EPA Method 353.2: Determination of nitrate-nitrite } \\
\text { nitrogen by automated colorimetry }\end{array}$ & $\begin{array}{l}\text { U.S. Environmental Protection Agency } \\
\text { (1993a) }\end{array}$ \\
\hline $\begin{array}{l}\text { Total ammonia plus } \\
\text { organic nitrogen }\end{array}$ & $\begin{array}{l}\text { EPA Method 351.2: Determination of total Kejeldahl } \\
\text { nitrogen by semi-automated colorimetry }\end{array}$ & $\begin{array}{l}\text { U.S. Environmental Protection Agency } \\
\text { (1993b) }\end{array}$ \\
\hline $\begin{array}{l}\text { Total phosphorus } \\
\text { Dissolved phosphorus }\end{array}$ & $\begin{array}{l}\text { EPA Method 365.2: Determination of phosphorus } \\
\text { by manual colorimetry }\end{array}$ & $\begin{array}{l}\text { U.S. Environmental Protection Agency } \\
\text { (1971) }\end{array}$ \\
\hline Total organic carbon & $\begin{array}{l}\text { Standard Method }{ }^{1} \text { SM5310B: High-temperature } \\
\text { combustion method }\end{array}$ & $\begin{array}{l}\text { American Public Health Association, } \\
\text { American Water Works Association, } \\
\text { and Water Pollution Control Federation } \\
\text { (1995) }\end{array}$ \\
\hline $\begin{array}{l}\text { Total lead } \\
\text { Total zinc }\end{array}$ & $\begin{array}{l}\text { EPA Method 200.8: Trace elements in waters } \\
\text { and wastes by inductively coupled plasma-mass } \\
\text { spectrometry }\end{array}$ & $\begin{array}{l}\text { U.S. Environmental Protection Agency } \\
\text { (1994) }\end{array}$ \\
\hline Total dissolved solids & $\begin{array}{l}{ }^{1} \text { Standard Method } 2540 \mathrm{C}: \text { Gravimetric total } \\
\text { dissolved solids dried at } 180{ }^{\circ} \mathrm{C}\end{array}$ & $\begin{array}{l}\text { American Public Health Association, } \\
\text { American Water Works Association, } \\
\text { and Water Pollution Control Federation } \\
\text { (1995) }\end{array}$ \\
\hline Total suspended solids & $\begin{array}{l}{ }^{1} \text { Standard Method } 2540 \mathrm{D} \text { : Gravimetric total } \\
\text { suspended solids dried at } 103-105^{\circ} \mathrm{C}\end{array}$ & $\begin{array}{l}\text { American Public Health Association, } \\
\text { American Water Works Association, } \\
\text { and Water Pollution Control Federation } \\
\text { (1995) }\end{array}$ \\
\hline Suspended sediment & ${ }^{2}$ Standard Test Method D3977-97 (2002) & $\begin{array}{l}\text { American Society for Testing and } \\
\text { Materials (2000) }\end{array}$ \\
\hline
\end{tabular}

${ }^{1}$ Standard methods for the examination of water and wastewater.

${ }^{2}$ Standard test methods for determing sediment concentration in water samples.

\section{Precipitation}

Precipitation was measured at each station and was recorded at 15-minute intervals, using self-calibrating tipping bucket rain gages that measure precipitation in 0.01 -inch increments. The rain gages were routinely cleaned and calibrated as outlined in the Surface-Water QualityAssurance Plan for the USGS Georgia Water Science Center (Gotvald, 2010).

Watershed precipitation estimates are based on the 13 USGS rain gages that are co-located with the stream gages at the watershed outlets and the 5 additional USGS gages within the study area (fig. 1; table 4). These precipitation gages are fairly well distributed across and along the margins of the study area and should reasonably represent the rainfall within the 13 watersheds. Daily precipitation within each watershed was approximated by averaging all available daily precipitation values, each weighted by the inverse distance squared between centroid of the watershed and the precipitation gage. Precipitation data were not available at all 18 gages for every day of the study period; some precipitation stations were added later in the study period and occasional equipment malfunction or poor data required that some data had to be discarded. Data coverage was generally good, with 99.2 percent of the days having data for 11 or more precipitation gages.

\section{Identification of Surface-Water Constituent Concentration Long-Term Trends}

Assessing whether water quality is improving, degrading, or unchanging is an important objective of this monitoring study, because the assessment provides Gwinnett County with information that allows them to be more proactive in managing their water resources and assessing the effectiveness of their implementation of best management practices for improving water quality. Identification of long-term temporal trends in water quality often requires a decade or more of monitoring because (1) natural climatic and seasonal variability can obscure or mimic trends in water quality, (2) degradation or improvement in water-quality conditions 
Table 4. Precipitation gages included in the study, including dates established and decommissioned, Gwinnett County, Georgia.

\begin{tabular}{|clll}
\hline $\begin{array}{c}\text { Station } \\
\text { number }\end{array}$ & \multicolumn{1}{c}{ Station name } & Start date & End date \\
\hline 02205000 & Wildcat Creek near Lawrenceville, Ga. & $10 / 4 / 2001$ & Active \\
\hline 02205522 & Pew Creek at Patterson Rd, near Lawrenceville, Ga. & $3 / 28 / 2003$ & $7 / 28 / 2014$ \\
\hline 02205865 & Sweetwater Creek at Club Drive near Lilburn, Ga. & $2 / 26 / 2010$ & Active \\
\hline 02207120 & Yellow River at Ga. 124, near Lithonia, Ga. & $4 / 26 / 1996$ & Active \\
\hline 02207185 & No Business Creek at Lee Road, below Snellville, Ga. & $3 / 1 / 2001$ & Active \\
\hline 02207385 & Big Haynes Creek at Lenora Road, nr Snellville, Ga. & $10 / 5 / 1998$ & Active \\
\hline 02207400 & Brushy Fork Creek at Beaver Road, nr Loganville, Ga. & $11 / 11 / 1998$ & Active \\
\hline 02208050 & Alcovy River near Lawrenceville, Ga. & $8 / 6 / 2003$ & Active \\
\hline 02208130 & Shoal Creek at Paper Mill Rd, nr Lawrenceville, Ga. & $10 / 1 / 2005$ & $7 / 28 / 2014$ \\
\hline 02208150 & Alcovy River at New Hope Road, near Grayson, Ga. & $1 / 1 / 1999$ & $9 / 15 / 2015$ \\
\hline 02217274 & Wheeler Creek at Bill Cheek Road, near Auburn, Ga. & $6 / 30 / 2001$ & Active \\
\hline 02218565 & Apalachee River at Fence Road, near Dacula, Ga. & $8 / 22 / 2001$ & Active \\
\hline 02334480 & Richland Creek at Suwanee Dam Road, near Buford, Ga. & $5 / 17 / 2001$ & Active \\
\hline 02334578 & Level Creek at Suwanee Dam Road, near Suwanee, Ga. & $5 / 10 / 2001$ & $5 / 16 / 2015$ \\
\hline 02334885 & Suwanee Creek at Suwanee, Ga. & $10 / 1 / 1996$ & Active \\
\hline 02335000 & Chattahoochee River near Norcross, Ga. & $6 / 29 / 2002$ & Active \\
\hline 02335350 & Crooked Creek near Norcross, Ga. & $3 / 23 / 2001$ & Active \\
\hline 02336030 & N.F. Peachtree Creek at Graves Rd, nr Doraville, Ga. & $6 / 9 / 2001$ & Active \\
\hline
\end{tabular}

can be delayed after watershed changes, and (3) effects on water-quality condition from multiple activities within a watershed can offset each other (Landers and others, 2007). Water quality varies in response to many natural processes that can be dominant factors on different or multiple time scales, for example, event-driven and seasonal hydrologic changes in sources and flow paths, seasonal changes in terrestrial and in-stream biogeochemical processes, and year-to-year climatic variations. These natural processes make it difficult to attribute the effects of human activity to changes in water quality. It is therefore imperative to remove as much of the effects of natural variation from water-quality data as possible. For water-quality constituents that vary strongly with discharge, streamflow can be the most influential effect on water quality to remove due to variations in discharge with climate. For long-term temporal trends, the natural effects of seasonal variability on water quality are less of an issue because of its relatively short-term, recurring nature.

Long-term trends in concentrations were evaluated for 12 watersheds for the 15-year period WYs 2001-15, and for the Sweetwater Creek watershed for the 6-year period WYs 2010-15, where monitoring was initiated later (table 1). To remove the effects of discharge and other natural processes on water-quality concentrations, trends were evaluated from residual concentrations of a flow-only regression model plotted versus time for 10 constituents: $\mathrm{TN}, \mathrm{NO}_{3}+\mathrm{NO}_{2}$, TP, DP, TOC, TSS, SSC, Pb, Zn, and TDS. This follows the approach presented in Hirsch and others (1991) and Helsel and Hirsch (1992). Residuals are defined as the observed concentration minus the model predicted concentration. The flow-only regression models used to estimate loads (described later) were used for the trend evaluations, because the additional explanatory variables used in the flow-turbidity models can capture human-induced changes in water quality that we seek to evaluate in the trend analysis. Similarly, any significant time and time-squared trend variables were excluded from the regression model, as the trend evaluations need to be independent of any trends fitted by the regression models. The long-term trend analysis was performed on the waterquality concentration data rather than load estimates because it is more straightforward to remove the effects of climatic variability related to discharge.

Base-flow and stormflow samples were evaluated together. Residuals were plotted and trends were evaluated in logarithmic space, because the regression models were based on log-transformed concentration. This also made it easier to compare the magnitudes of the slope of the trend of different water-quality constituents. A linear trend line was fitted to the residual concentrations in logarithmic space to help illustrate any underlying trends and to evaluate its significance. A trend was considered significant if the fitted trend line had a $p$-value of $\leq 0.05$. The trends did not necessarily vary linearly, and more detailed temporal variations in trends can be discerned from the temporal pattern in the residual plots. 


\section{Constituent Load Estimation}

Constituent load, often referred to as mass flux, is the mass of chemical constituent or sediment transported at a point in a stream during a specific period. Load serves as an integrated measure of all processes within the watershed that affect water quality (Semkin and others, 1994). With increased emphasis on watershed-based strategies for the control of nonpoint-source pollutants, reliable, temporal measures of loads are needed to address whether water quality is improving or degrading within a reasonably short period of time. In the United States, stream reaches that do not meet U.S. Environmental Protection Agency water-quality standards (U.S. Environmental Protection Agency, 2000a) are subject to waste-load allocation schemes that are based on the total maximum daily load (TMDL). A TMDL is defined as the maximum amount of a pollutant that a water body can receive and still meet water-quality standards (U.S. Environmental Protection Agency, 2000b).

Constituent load $(L)$ is the product of constituent concentration $(C)$ and discharge $(Q)$ integrated over time $(t)$ :

$$
L=\int C(t) Q(t) d t
$$

Load estimation using the integral in equation 1 requires a continuous record of both concentration and discharge. Although discharge can readily be measured in a nearly continuous manner, constituent concentration typically is measured less frequently because of the effort and expense of collecting and analyzing samples for water quality. Various techniques have been developed to estimate loads using discrete concentration observations. These techniques can be categorized into four classes: (1) averaging methods, (2) period-weighted approaches (for example, Likens and others, 1977; Larson and others, 1995), (3) regression-model (or rating-curve) methods, and (4) ratio estimators (for example, Dann and others, 1986; Preston and others, 1989). The moderate to strong concentration-discharge relations for most of the constituents used herein along with the relatively infrequent sampling in this study indicate that a regression-model method is most appropriate (Aulenbach and others, 2016) and is used herein to estimate loads. In this approach, $C(t)$ is estimated continuously using a regression model that relates concentration to continuously measured variables, such as discharge and day of year (Johnson, 1979; Crawford, 1991; Cohn and others, 1992), thus enabling a direct calculation of equation 1 . The regression model predicts the average concentration response for the set conditions, such as discharge and season.

Loads were estimated for WYs 2003-15 for 12 watersheds and for WYs 2011-15 for the Sweetwater Creek watershed. Loads were estimated for 10 constituents: TN, $\mathrm{NO}_{3}+\mathrm{NO}_{2}$, TP, DP, TOC, TSS, SSC, Pb, Zn, and TDS. Loads were reported on an annual basis. The load estimation methods used herein are similar to those used in the previous two reports, Landers and others (2007; WYs 1996-2003) and Joiner and others (2014; WYs 2004-09). The only change in approach from the second report was the addition of several regression model terms to model climatic variability and improve model fit. These terms were daily base flow, streamflow during base-flow conditions, and allowing the use of both the turbidity during all flow conditions and turbidity during stormflow conditions terms within the same model.

The regression models were developed and load estimates were estimated using the USGS LOAD ESTimator software (LOADEST; Runkel and others, 2004), using the adjusted maximum likelihood estimates (AMLE) algorithm (Cohn and others, 1989, 1992). This algorithm applies a correction factor to account for retransformation bias of a logarithmic model transformed back to linear space (Ferguson, 1986) and can appropriately handle censored water-quality data - concentrations that are below the analytical detection limit. The TIBCO Spotfire S+ statistical software (version 8.1) computing platform version of LOADEST software was used in this analysis.

The typical regression-model load estimation method required modification to handle the use of storm composite samples. When estimating the loads, it is inappropriate to apply the concentration-discharge relation developed from the storm composite samples to the instantaneous discharges, because the average storm concentration versus average storm-discharge relation differs from the instantaneous concentration-discharge relation. Thus, this study used the approach developed by Landers and others (2007) in which loads were estimated from average discharge on the basis of a predetermined time step instead of from instantaneous discharge. This time step is related to the average duration of storms sampled for each watershed. Each watershed was analyzed to determine the optimal time step to use for stormflow load estimation based on the median duration of sampled storms and ranged from 4 to 24 hours. LOADEST can estimate loads at time intervals as short as 1 hour. The time step is longer for larger watersheds because of the integration of runoff over a larger area with varied and longer travel times to the watershed outlet as well as the attenuation of the storm hydrograph as the runoff travels downstream, which reduces peak flows and spreads out the hydrograph over time. This average-discharge load estimation approach can likewise be reasonably applied to the instantaneous concentrationdischarge relation developed from base-flow samples as well, because during base-flow conditions, discharge does not change rapidly, and instantaneous and average discharges would not be significantly different.

A 12-parameter regression model was developed for estimating loads in LOADEST and has the form of natural logarithm of load as a function of variables including discharge, base flow, season, time, and turbidity (from the continuous water-quality sensors):

$$
\begin{aligned}
\ln (L)= & a_{0}+a_{1} S+a_{2} \ln Q+a_{3} \ln Q^{2}+a_{4}(1-S) \ln Q+a_{5} \ln Q_{\mathrm{b}} \\
& +a_{6} \ln T+a_{7} S \ln T+a_{8} \sin (2 \pi d t i m e) \\
& +a_{9} \cos (2 \pi \text { dtime })+a_{10} \text { dtime }+a_{11} \text { dtime }
\end{aligned}
$$


where:

$L \quad$ is load, the product of concentration and discharge, in pounds per day;

$S \quad$ is an indicator variable that indicates the flow condition, 0 for base flow and 1 for stormflow;

$Q$ is streamflow, centered, in cubic feet per second;

$Q_{\mathrm{b}} \quad$ is daily base flow, in cubic feet per second;

$T$ is turbidity, in Formazin Nephelometric Units;

dtime is decimal time, centered, in years; and

$a_{0} \ldots a_{11}$ are regression model coefficients.

Although equation 2 is a function of load, to make the details given below more understandable, we refer to the relations as a function of concentration. This is just a matter of semantics, as equation 2 could be written as a function of concentration, and predicted concentrations could then be multiplied by streamflow resulting in the same load estimates as if it were a function of load.

The daily base-flow variable, $Q_{\mathrm{b}}$, was included to capture the climatic status of the watershed. Although base flow generally varies seasonally, it should better reflect the observed climatic condition than the seasonal terms that fit a set pattern for all years. The variable $Q_{\mathrm{b}}$ was calculated by hydrograph separation of daily average streamflow as previously described.

Turbidity, $T$, is a surrogate variable in which predicted concentrations are modeled as a function of this chemically related, continuously available optical variable. Surrogate variables are powerful for capturing variations in concentrations and in the resulting loads, because the predicted concentrations can better reflect variations through time based on the relation with observed changes in the continuous surrogate. The turbidity surrogate typically is useful for constituents that have a substantial particulate component, as increases in turbidity are related to less light transmission due to solid particles in the water column blocking light. Most of the other variables in equation 2 are static throughout the model calibration time period, such that they always predict the average response for the period. The exception to this is the time and time-squared terms, which can adjust the model intercept over time in a fixed second-order polynomial pattern. Other approaches and methods allow for variations in variable relations over time, such as concentration-discharge relations, to improve incorporation of variability in estimated loads. These methods include using a shorter moving-window calibration time period (Yochum, 2000; Aulenbach and others, 2007) or using weighted regression on time, discharge, and season (WRTDS; Hirsch and others, 2010), but these methods generally require more frequent sampling to adequately define the changes over time.

The model form was designed with the flexibility to fit base-flow and composite storm samples simultaneously in order to expedite the model fitting process by reducing the number of models to be fit in half. The samples not only differ in whether the samples represent instantaneous or average concentrations, they also represent two distinct flow regimes that may have distinct concentration relations. In some cases these two types of samples follow a single concentration relation, while in other cases they have separate relations. The model terms were formulated to allow for differences in the relations for an offset, streamflow and turbidity while fitting a single relation for season and long-term trends. The "indicator variable" $S$ was used in the regression model equation to indicate whether hydrologic conditions of the sample were during base flow $(S=0)$ or stormflow $(S=1)$. The indicator variable controls the absence (multiplied by zero) or presence (multiplied by one) of the use of a variable within the model equation. The variable $S$ was used to adjust for any offset in load of the stormflow samples relative to the overall model intercept $a_{0}$. The load-streamflow relation was fit for both flow conditions with a second-order polynomial, $\ln Q$ and $\ln Q^{2}$, while any differences in this relation during base-flow conditions were adjusted using the $(S-1) \ln Q$ term. The loadturbidity relation was fit using the terms $\ln T$ and $S \ln T$, where inclusion of $\ln T$ indicated a single turbidity relation for all flow conditions, $S \ln T$ indicated a turbidity relation only during stormflow conditions, and both terms indicated different turbidity relations for base-flow and stormflow conditions.

Two load models were fitted for each constituentwatershed combination, a flow-turbidity model that included at least one of the two turbidity terms and a flow-only model that was fit excluding the turbidity terms. The flow-only model was used as a fallback to the flow-turbidity model, to estimate loads when there were missing data in the continuous turbidity record. Gaps are to be expected in data from continuous waterquality sensors due to their high maintenance requirements and penchant for malfunctions. The flow-turbidity model typically outperformed the flow-only model. Flow-turbidity models were not created for all constituent-watershed combinations because model turbidity terms were sometimes not significant, as was often the case for dissolved constituents.

During the model parameter fitting process, if a parameter was not significant ( $p$-value $>0.05$ ), the term was excluded from the regression model to avoid overparameterization, which is when models include variables that do not explain much variation in the concentrations. Initially, all model terms were included. Model terms were then removed in a backward-stepwise fashion by incrementally removing the term with the highest $p$-values until all remaining terms had $p$-values $<0.05$. The seasonal sine and cosine model terms worked as a single variable and were both included in the model as long as one term had a $p$-value $<0.05$. In the rare case where the linear time term had a $p$-value $>0.05$ and the time-squared term had a $p$-value $<0.05$, both terms were included in the model. Occasionally the backward-stepwise fashion approach was exempted when a better model was found to explain more variance and exhibited better model residual behavior. Model variables $Q$ and dtime were 
"centered"- had their central value subtracted from themto remove correlation between their linear and squared terms such that the terms were independent of each other. Correlation between model terms can affect tests of significance of model terms.

To ensure that regression models fit the observed relations well, outliers that could affect model predictions were removed from the model, and model residuals were inspected to ensure that model predictions would not be biased. Outliers can have an undue influence on the model fit due to the minimization of the squared errors fitting process that gives outliers greater weights. Before fitting the regression models, concentration data were checked for outliers by plotting concentrations versus variables used in the regression models: date, day-of-year, streamflow, and turbidity. Concentrations were also plotted versus other constituents where relations might be expected to exist: dissolved constituents were plotted versus the other dissolved constituents and specific conductance, total constituents were plotted versus the other total constituents, and nutrients were plotted versus the other nutrients. When a concentration was observed well outside any relation between concentration and variables used in the regression models and would affect the model fit, the concentration was identified as an outlier. Consideration for outlier identification was also given to concentrations that did not fit overall patterns with other constituents, but this required multiple observations of evidence to ensure that the concentration was the outlier and not the constituent concentration it was plotted against. Identified outliers were not necessarily in error, but may represent some condition that occurs so rarely that it would be inappropriate to adjust the model toward such an ephemeral condition; such as from a transient point-source pollutant. All 245 outliers are listed in Aulenbach and Joiner (2017; table 1, water-quality outliers excluded from load model calibrations) and represent 1.5 percent of the total number of concentrations considered for the load calculations.

Model residuals also were examined to ensure that they were identically (randomly) distributed. In some cases, small patterns were observed but were not great enough to have considerable effect on biasing the load estimates. More often, the residuals did not follow a normal distribution. In this case, the AMLE approach may not provide optimal load estimates for censored data (Runkel and others, 2004). An alternative load estimation approach that does not require residuals to be distributed normally is available in LOADEST. Unfortunately, this alternative was not applicable, because the cases where residuals were not normal typically had censored values, and the least absolute deviation (LAD) approach implementation in LOADEST does not allow censored data. Models that did not have normally distributed residuals can be identified as having a Turnbull-Weiss normality test statistic $p$-value of $<0.05$. This test statistic is reported for all models in Aulenbach and Joiner (2017; table 3, load estimation regression models). For models where residuals were not distributed normally, load estimates may be less accurate than their confidence intervals indicate.
Although load estimates are reported beginning in WY 2003, the calibration datasets used to fit the regression models extend back to WY 2001 when data were available. During model prediction, time periods in the estimation file are set to zero during base-flow conditions and one during stormflow conditions. Hydrologic conditions were based on levels of turbidity or discharge instead of determined from the dynamics of the hydrograph, which requires a hydrograph separation. For the streams in this study, turbidities greater than 20 Formazin Nephelometric Units (FNU) were determined to be indicative of stormflow, because only about 6.7 percent of base-flow samples had turbidities $\leq 20$ FNU and only about 11.2 percent of stormflow samples had turbidities $\geq 20$ FNU. Therefore, conditions were determined as stormflow when turbidity from the continuous water-quality sensor was greater than or equal to this $20 \mathrm{FNU}$ threshold. If turbidity data were missing, then discharge was used to determine stormflow conditions - stormflow was defined to have occurred when discharge was greater than the average of the 50th and 75th percentiles of discharge for that watershed.

Load is highly dependent on the amount of runoff; hence, large watersheds typically will transport high loads. To better compare load from different sized watersheds, load was divided by the watershed area to determine yield, which is the load per unit area.

\section{Load Estimation Error}

Quantifying the errors in the load estimates is important in order to understand whether a difference in load represents a significant difference or change in load, or whether the difference is within the errors of the estimates. The error bounds are also a guide to the magnitude of change that is required for a trend to be detected. There are many sources of errors, including streamflow measurements, water-quality sample representativeness, laboratory analytical measurements, and load estimation calculations. Horowitz (2003) indicated that suspended-sediment load errors of less than or equal to $\pm 15-20$ percent should be considered relatively accurate for small to large rivers and for load estimates reported for quarterly to greater time frames.

Error estimates were calculated using the LOADEST software and reported for all the annual loads and yields. For three watersheds (No Business Creek, Apalachee River, and Crooked Creek), annual error estimates could not be calculated for $\mathrm{Pb}$ because of technical issues with the software. LOADEST calculates both the standard error (SE) and the standard error of the prediction (SEP) of the mean load estimate. The SE represents the variability attributed to parameter uncertainty of the model calibration, while the SEP also includes the effects of random error. Therefore, SEP tends to be larger than SE, but SEP provides a better estimate of the errors between the load estimates and the actual loads. SEP calculations assume that the errors are independent in time (no serial correlation), because underlying serial correlation can result in SEPs underestimating the actual uncertainty in 


\section{Load estimation error conventions}

In this report, errors are based on the SEP and are expressed as 95 percent lower and upper confidence intervals. Errors are reported in a probabilistic manner, meaning that the range of values should be reliably within the range of the errors a defined percentage of the time. Two standards are commonly reported and users should be careful to note which standard is being used because the 95 percent confidence interval standard has error bounds almost twice as large as the plus or minus one standard error standard even though both represent the same amount of error. The 95 percent confidence interval standard represents the range of values that should likely be expected about 95 percent of the time and can be thought of as error bounds that are "rarely exceeded." The plus or minus one standard error method represents the range of values that should be within about 68.3 percent of the time and can be thought of as error bounds that are "likely to be within more often than not." The errors reported are assumed to follow a normal probability distribution, and as load models were created in logarithmic space, the upper 95 percent confidence interval will be larger than the lower 95 percent confidence interval. Landers and others (2007) previously reported LTTM program watershed load errors using the plus or minus one standard error method.

the load estimates (Aulenbach, 2013). The size of error for any given year depends on the actual streamflow and turbidity observed for that year.

Error estimates are complicated by the fact that some loads estimates are combined from one model that includes turbidity and one that does not. The annual error in loads of the combined models was estimated by weighting the annual errors of the two models by the fraction of annual runoff each of the models contributed to the annual load. The lower $\left(C I_{95 \% \text { Lower }}\right)$ and upper $\left(C I_{95 \% \text { Upper }}\right) 95$ percent confidence intervals are estimated using equations 3 and 4 , respectively.

$$
\begin{aligned}
C I_{95 \% \text { Lower }} & =L_{\text {Total }}-\left[\left(L_{Q T}-C I_{95 \% \text { Lower }(Q T)}\right) * R F_{Q T}\right. \\
& \left.+\left(L_{Q}-C I_{95 \% \text { Lower }(Q)}\right) * R F_{Q}\right] \\
C I_{95 \% \text { Upper }} & =L_{\text {Total }}+\left(C I_{95 \% \text { Upper }(Q T)}-L_{Q T}\right) * R F_{Q T} \\
& +\left(C I_{Q 95 \% \text { Upper }(Q)}-L_{Q}\right) * R F_{Q}
\end{aligned}
$$

where

$$
\begin{aligned}
L_{\text {Total }} & \text { is the total annual load; } \\
L & \text { is annual load; } \\
R F & \text { is the annual runoff fraction for that model's } \\
& \text { load; and }
\end{aligned}
$$

$Q T$ and $Q \quad$ represent the flow-turbidity and flow-only models, respectively.

Confidence intervals for yields were then calculated from the load estimate confidence intervals.

Errors for plots showing annual loads for the combined LTTM program study area and for individual watersheds for the entire study period were calculated by combining the errors from the annual loads. These errors were combined by adding them in quadrature (that is, squared, added, and then square rooted), which is a common approach for combining error when summing multiple values (Kirchner, 2001).

\section{Watershed Characteristics}

Watershed characteristics were determined for the 13 watersheds in the LTTM program, including basin characteristics, population, land use, and percentage of impervious area. Basin characteristics, such as geology, drainage systems, altitudes, and basin slopes can all affect surface-water quantity and quality. Population growth and the resulting land-use changes can make watershed management more challenging, because increases in impervious areas typically are associated with increased storm runoff and decreased base flow, and population growth increases the demands on the water supply and for wastewater treatment.

\section{Basin Characteristics}

Gwinnett County is located in north-central Georgia, about 15 miles northeast of Atlanta (fig. 1). The county, which encompasses 436.8 square miles $\left(\mathrm{mi}^{2}\right)$, is located in the Piedmont physiographic province. The geology of the county is a mixture of complex and varied metamorphic rocks (U.S. Geological Survey, 2014). Gwinnett County is composed predominantly of headwater streams that drain into one of three major rivers: the Chattahoochee, the Ocmulgee, and the Oconee. The Eastern Continental Divide, which separates drainages that flow into the Gulf of Mexico from those that flow into the Atlantic Ocean, runs approximately northeastsouthwest across the northwestern portion of the county. Five study watersheds (Richland Creek, Level Creek, Suwanee Creek, Crooked Creek, and North Fork Peachtree Creek) are northwest of the divide and lie within the ApalachicolaChattahoochee-Flint River Basin, which flows into the Gulf of Mexico. The remaining eight study watersheds (Sweetwater Creek, Yellow River, Alcovy River, Big Haynes Creek, Brushy Fork Creek, No Business Creek, Wheeler Creek, and Apalachee River) lie within the Ocmulgee-Oconee-Altamaha 
River Basin, which flows into the Atlantic Ocean (fig. 1). The watersheds cover an area of $306.6 \mathrm{mi}^{2}, 300.2$ of which lie within Gwinnett County and compose 68.7 percent of the county (table 5). The watershed sizes range across two orders of magnitude, from the smallest at $1.31 \mathrm{mi}^{2}$ (Wheeler Creek) to the largest at $161.4 \mathrm{mi}^{2}$ (Yellow River; covering 52.65 percent of the study area).

Land-surface altitudes in Gwinnett County range from 297 to 1,293 feet above North American Vertical Datum of 1988 (NAVD 88; fig. 3; table 5). Altitudes generally are highest in the northern portion of the county and lowest in the southern and eastern portions of the county. Note that the Yellow River watershed contains a deep quarry in the eastern portion of the watershed, resulting in artificially low altitudes within the basin, although the watershed outlet is at an altitude of about 730 feet.

The mean land-surface slope within the area of the LTTM program watersheds is 11.4 percent, with mean basin slopes ranging from 7.4 percent (Brushy Fork Creek watershed) to 16.7 percent (Richland Creek; table 5; fig. 4). Higher landsurface slopes are observed more commonly in the northern portion of the county within the Apalachicola-ChattahoocheeFlint River Basin (fig. 5). Landers and others (2007) showed that higher basin slopes in Gwinnett County were significantly correlated to lower base-flow yield and higher annual TP yields. Note that mean basin slopes in this study differ slightly from those published in Landers and others (2007) and Joiner and others (2014), because the slopes provided herein are derived from more recent, higher quality altitude data from Gwinnett County Department of Public Utilities (unpub. data, 2014).

\section{Population}

Gwinnett County is a densely populated, primarily suburban to urban county of the Atlanta metropolitan area. The population in Gwinnett County in 2015 was about 919,000 (fig. 6), about 2,100 people per square mile; whereas, the national average in 2010 was 87.4 people per square mile (U.S. Census Bureau, 2011). Gwinnett County has undergone rapid population growth from about 1980 through 2015, and land use has changed from what was once predominantly agriculture and forest to a highly developed area. Population in Gwinnett County increased by about 269,000 people from 2001 to 2015 , an average of about 21,100 people per year and a 47 percent increase since 2001 (figs. 6 and 7). Population growth was fairly steady during this period except from 2008 to 2011, when growth was slower and even declined in one year. This downturn appears to be associated with the "Great Recession" economic downturn that occurred between December 2007 and June 2009.

The population density is greater in the western portion of the county and along the major roadways (fig. 8). Average watershed population densities ranged from about 880 (2009) and 940 (2013) people per square mile in the Wheeler Creek watershed to about 4,200 (2009) and 4,300 (2013) people per square mile in the North Fork Peachtree Creek watershed (fig. 9). Population densities increased in all watersheds between 2009 and 2013, but increases varied greatly between watersheds, ranging in annual rates from a low of 0.3 people per square mile per year (Richland Creek) to a high of 44 people per square mile per year (Big Haynes Creek).

Table 5. Watershed characteristics for 13 watersheds in Gwinnett County, Georgia.

[NAVD 88, North American Vertical Datum of 1988]

\begin{tabular}{|c|c|c|c|c|c|c|c|c|}
\hline \multirow[b]{2}{*}{$\begin{array}{l}\text { Station } \\
\text { number }\end{array}$} & \multirow[b]{2}{*}{ Watershed name } & \multicolumn{2}{|c|}{ Drainage area } & \multicolumn{4}{|c|}{ Altitude (feet above NAVD 88) } & \multirow[b]{2}{*}{$\begin{array}{c}\text { Mean } \\
\text { basin slope } \\
\text { (percent) }\end{array}$} \\
\hline & & $\begin{array}{l}\text { (square } \\
\text { miles) }\end{array}$ & $\begin{array}{c}\text { Percentage } \\
\text { of study } \\
\text { area }\end{array}$ & Minimum & Maximum & Range & Mean & \\
\hline 02205865 & Sweetwater Creek & 21.0 & 6.84 & 854 & 1,177 & 323 & 985 & 11.3 \\
\hline 02207120 & Yellow River & 161.4 & 52.65 & 297 & 1,215 & 918 & 968 & 11.1 \\
\hline 02207185 & No Business Creek & 10.1 & 3.28 & 738 & 1,202 & 464 & 930 & 10.5 \\
\hline 02207400 & Brushy Fork Creek & 8.18 & 2.67 & 885 & 1,101 & 216 & 985 & 7.4 \\
\hline 02208150 & Alcovy River & 30.8 & 10.05 & 787 & 1,213 & 426 & 1,014 & 11.6 \\
\hline 02217274 & Wheeler Creek & 1.31 & 0.43 & 884 & 1,105 & 221 & 992 & 11.0 \\
\hline 02218565 & Apalachee River & 5.65 & 1.84 & 928 & 1,201 & 273 & 1,064 & 11.3 \\
\hline 02335350 & Crooked Creek & 8.87 & 2.89 & 872 & 1,176 & 304 & 996 & 12.1 \\
\hline 02336030 & North Fork Peachtree Creek & 1.53 & 0.50 & 931 & 1,100 & 169 & 1,020 & 10.2 \\
\hline \multicolumn{2}{|c|}{ LTTM program study area } & 306.6 & 100 & 297 & 1,293 & 996 & 1,000 & 11.4 \\
\hline
\end{tabular}




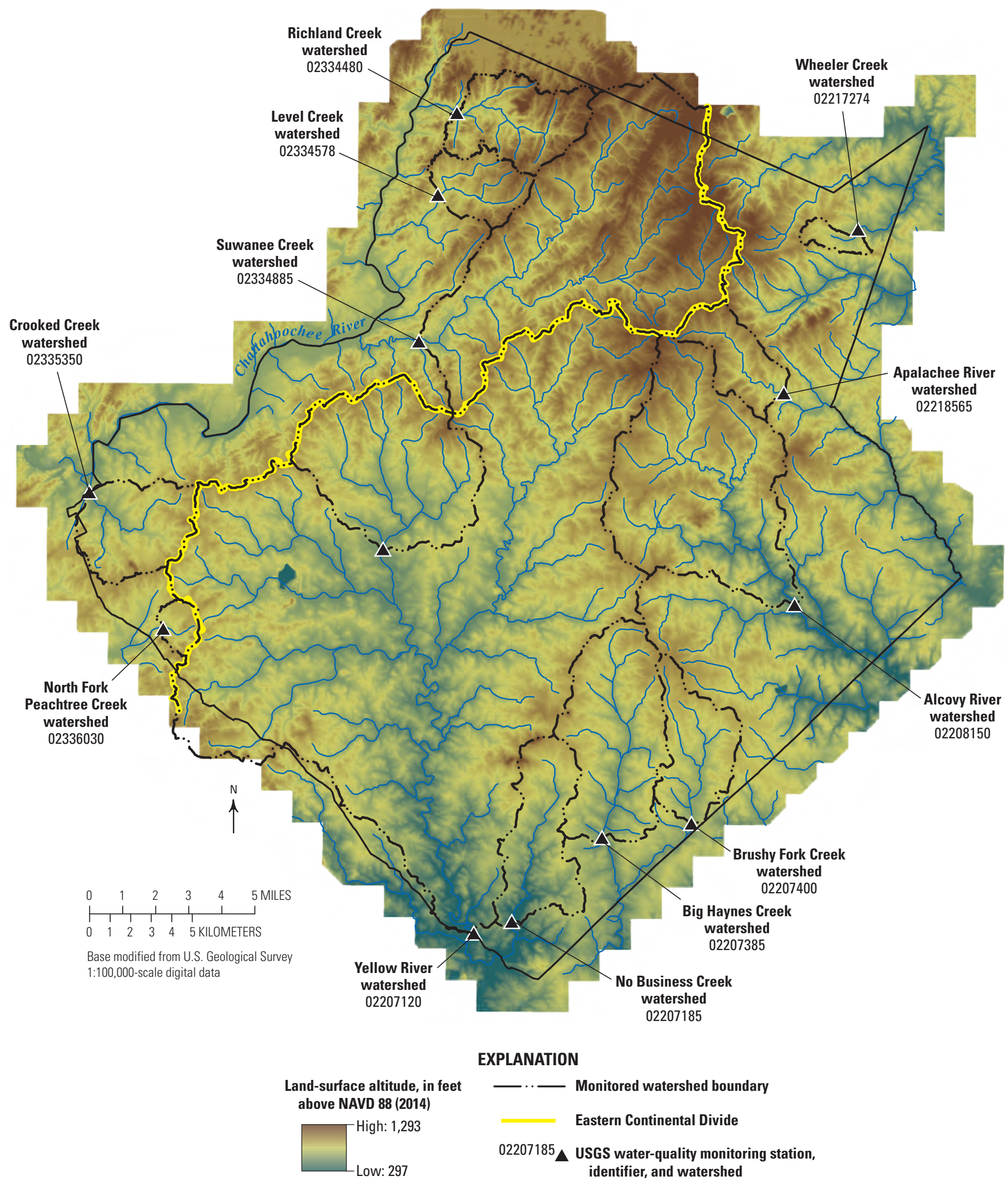

Figure 3. Land-surface altitude for Gwinnett County, Georgia. Altitude data from aerial light detection and ranging (lidar; laser-radar) survey from Gwinnett County Department of Public Utilities, unpub. data, 2014. 


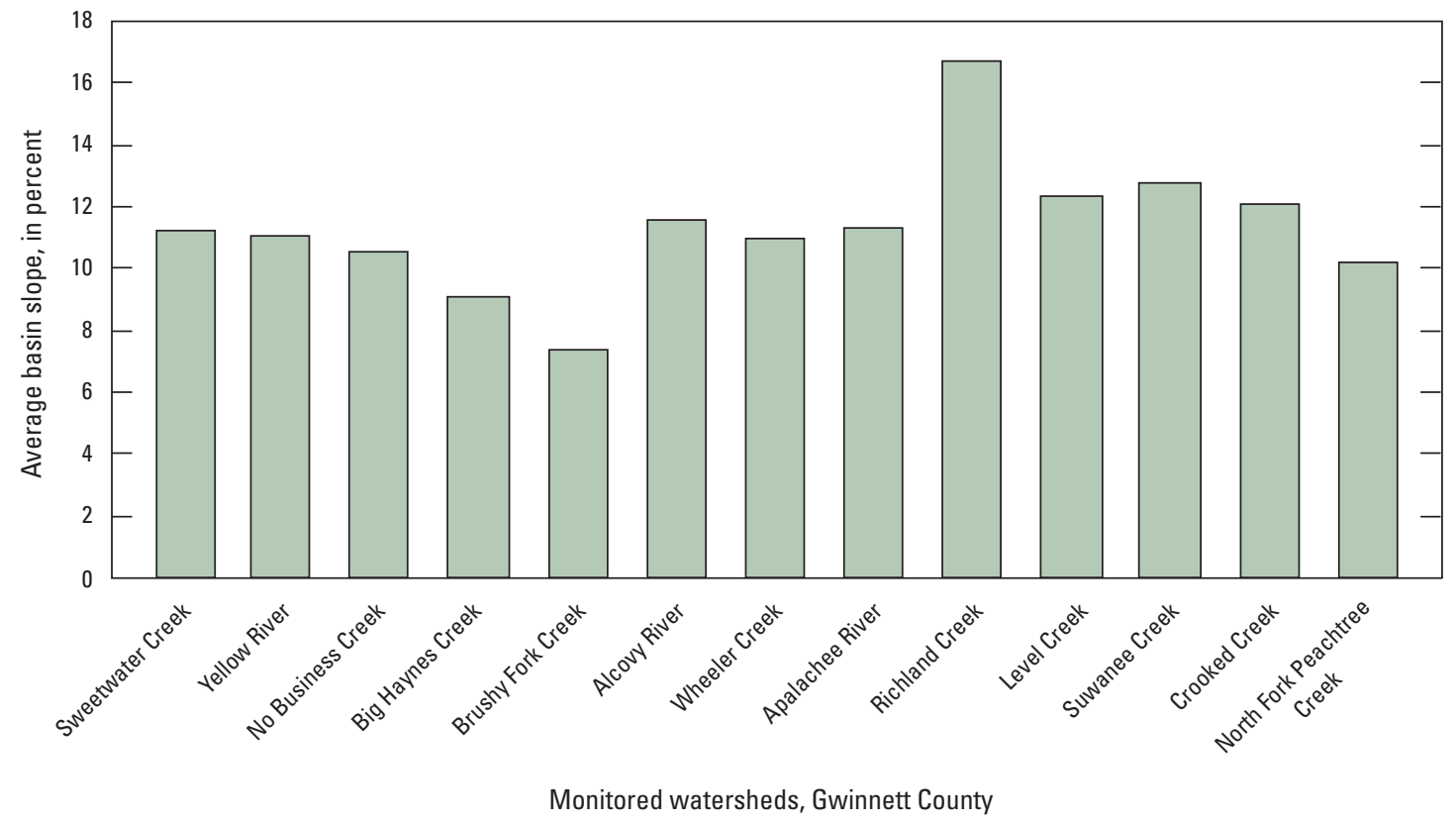

Figure 4. Average basin slope of the 13 monitored watersheds in Gwinnett County, Georgia. Derived from altitude data from Gwinnett County Department of Public Utilities, unpub. data, 2014. 


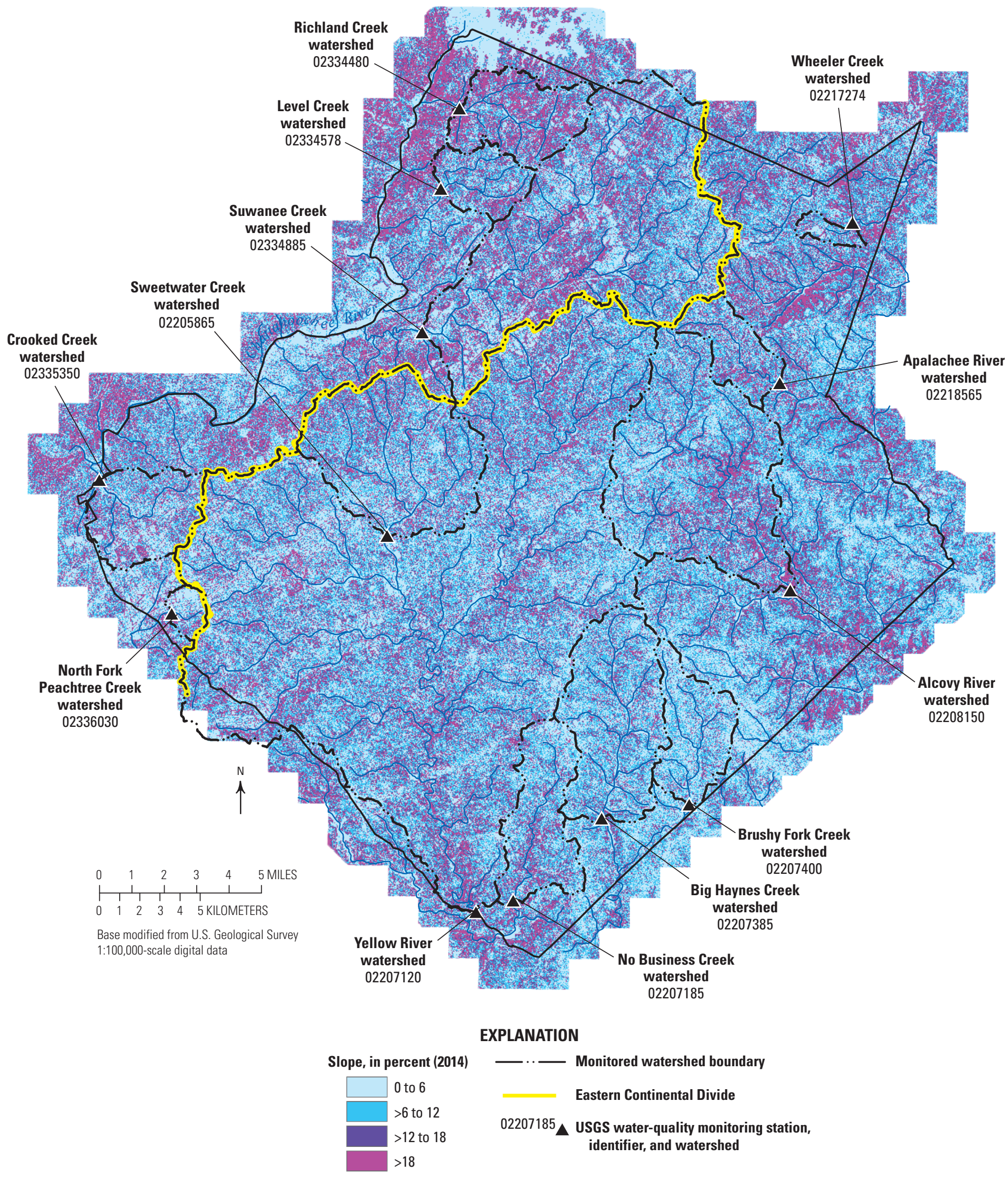

Figure 5. Land-surface slope for Gwinnett County, Georgia. Derived from altitude data from Gwinnett County Department of Public Utilities, unpub. data, 2014. 

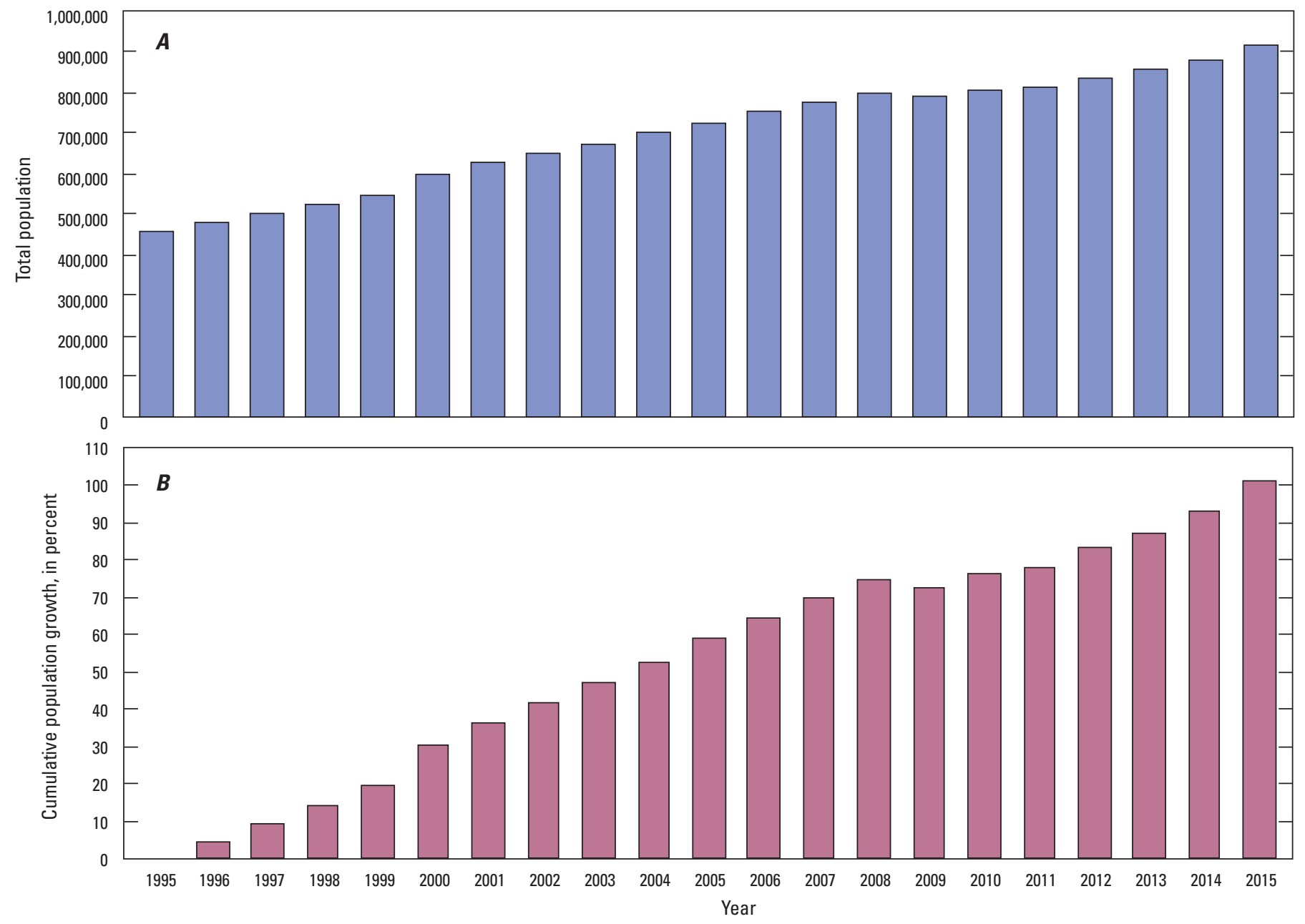

Figure 6. (A) Total population by year and $(B)$ population growth for Gwinnett County, Georgia, 2001-15. Data from U.S. Census Bureau (2004, 2011) and Gwinnett County, Georgia (2004, 2005, 2006, 2007, 2008, 2009, 2010, 2012, 2013, 2014, 2015, 2016).

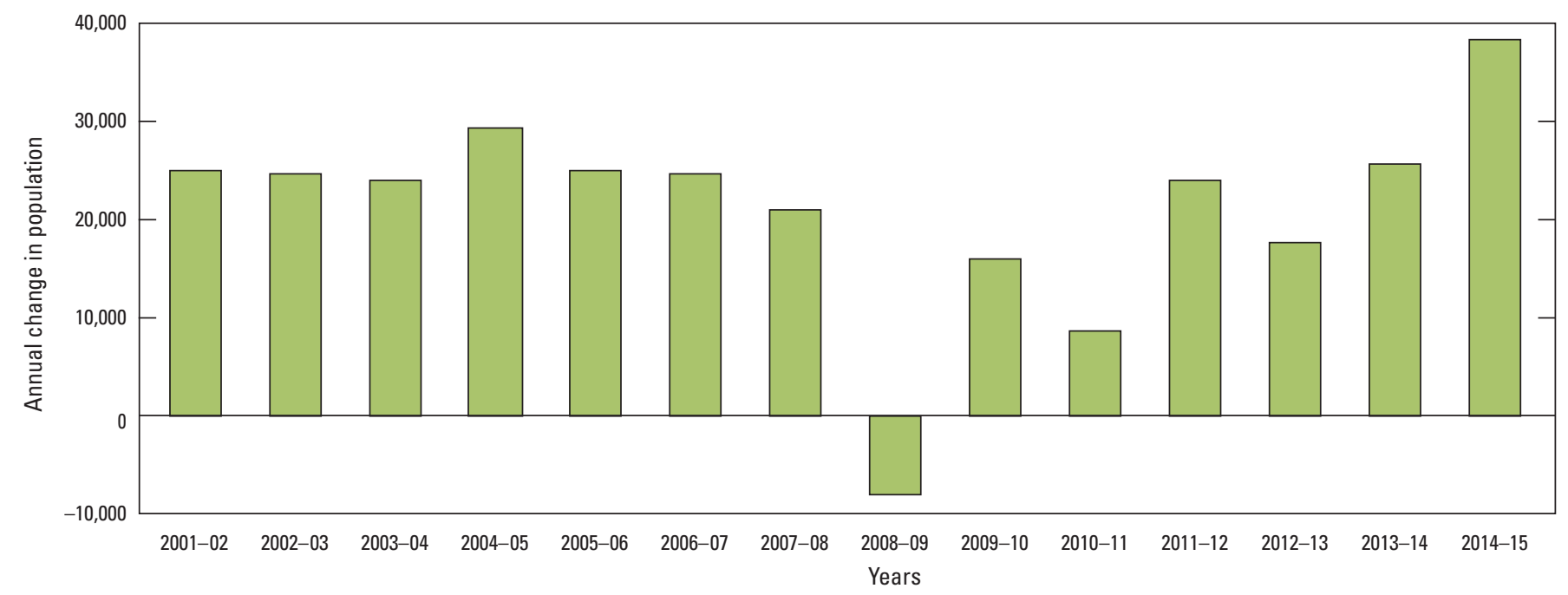

Figure 7. Annual change in population for Gwinnett County, Georgia, from 2001 to 2015. 


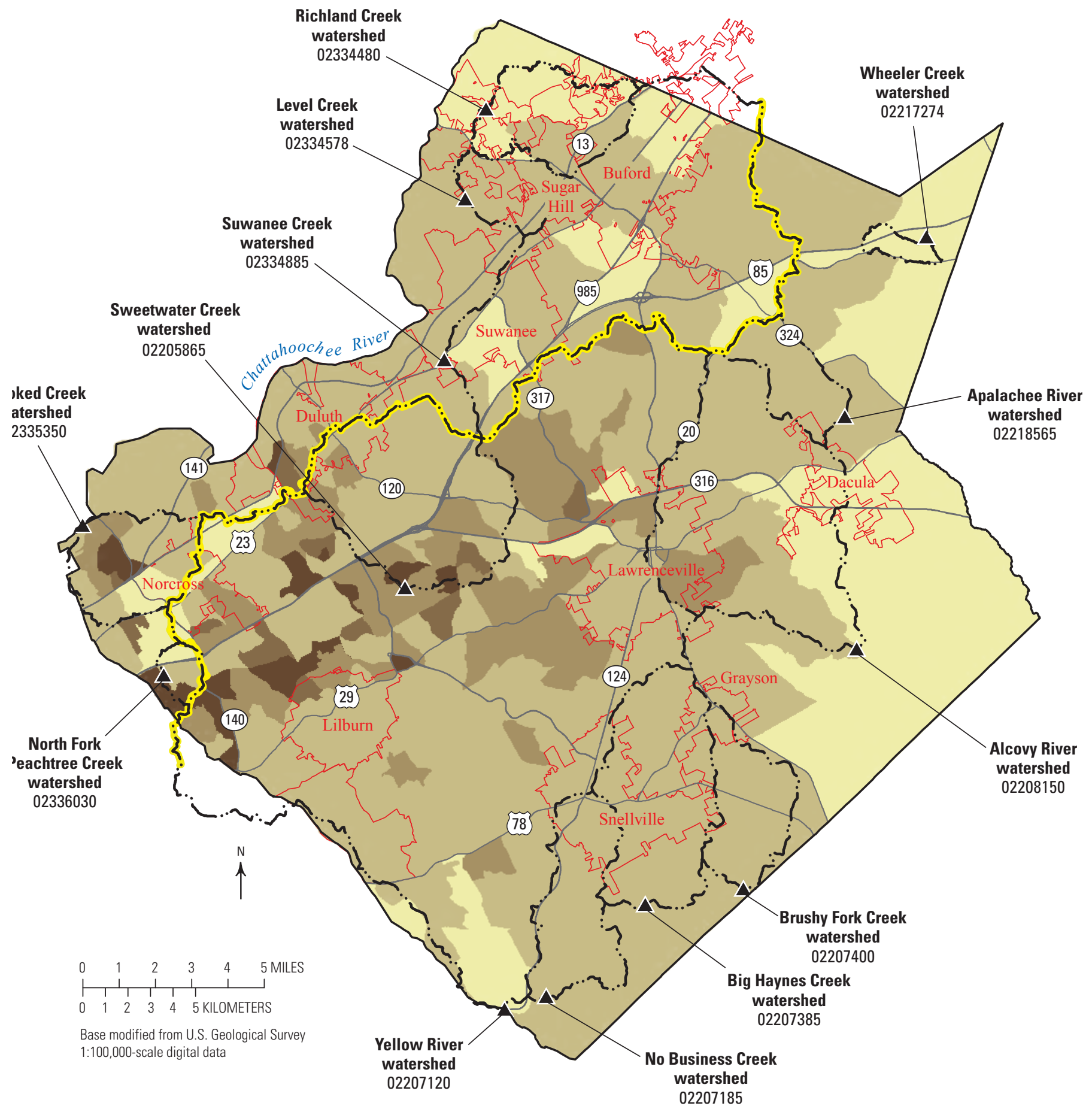

\section{EXPLANATION}
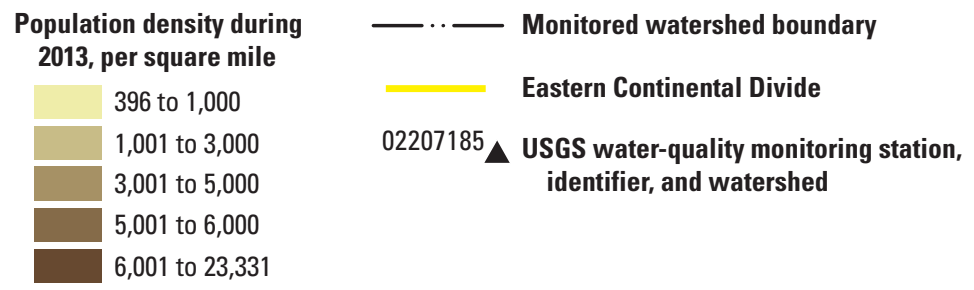

Figure 8. Population density for Gwinnett County, Georgia, 2013. Data from American community survey 5-year estimates of 2009-13 block group data, U.S. Census Bureau, 2014. 


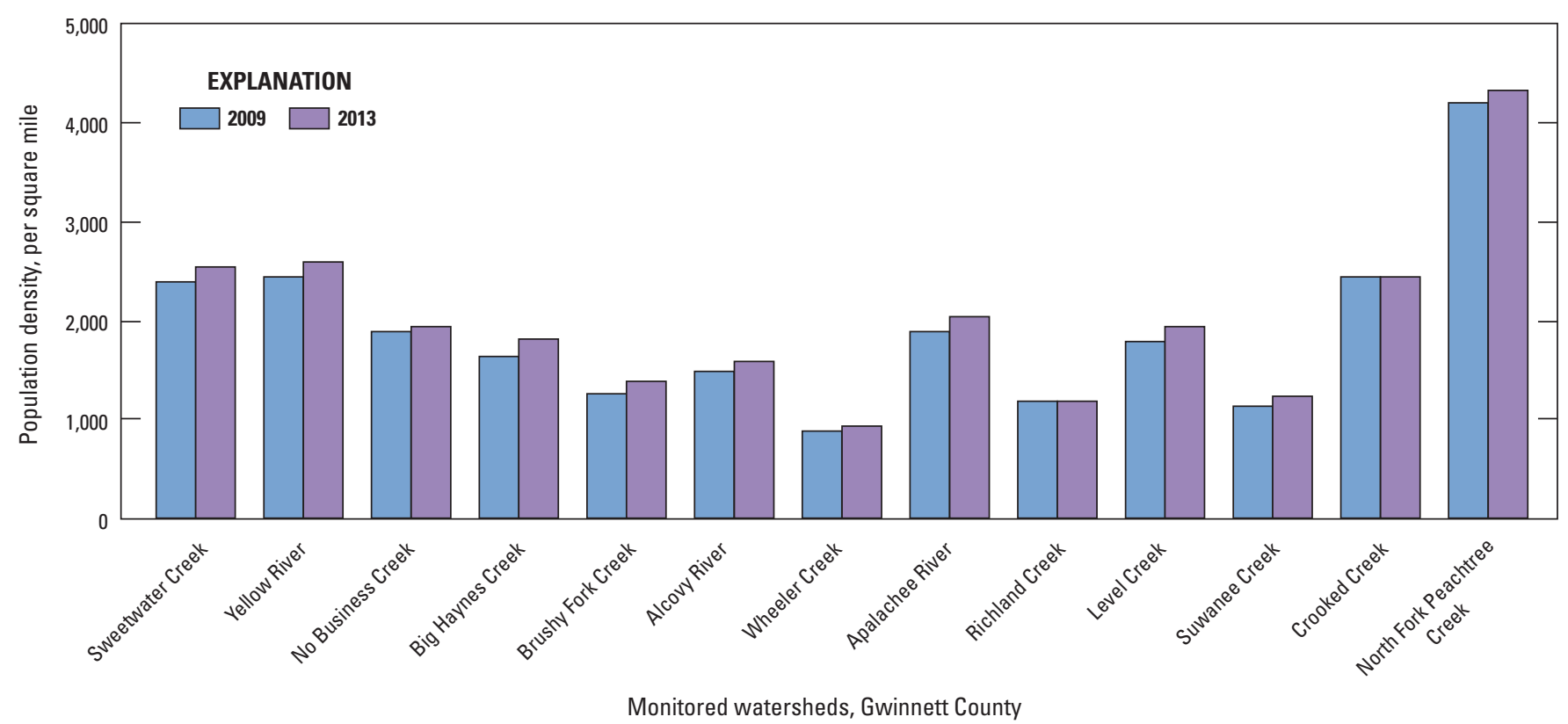

Figure 9. Population density for the 13 monitored watersheds in Gwinnett County, Georgia, in 2009 and 2013. Derived from American community survey 5-year estimates of 2006-10 and 2009-13 block group data, U.S. Census Bureau, 2012 and 2014, respectively.

\section{Land Use and Changes in Impervious Area}

Land use and impervious area are summarized for the 13 LTTM program watersheds in table 6; data are based on the Atlanta Regional Commission 2012 land-use dataset (2012). Individual land-use categories have been grouped into six categories: high density, low density, estate/park, transportation/utilities, undeveloped/water, and other. Land use varies greatly among watersheds. For example, North Fork Peachtree Creek and Crooked Creek watersheds have much higher high-density land use, while No Business Creek, Big Haynes Creek, and Apalachee River watersheds have higher low-density land use, relative to the other watersheds.

Impervious areas have been shown to have substantial effects on rainfall-runoff relations. Impervious areas reduce infiltration and, hence, groundwater recharge, resulting in lower base flows. Impervious areas also increase runoff rates, resulting in a "flashy" hydrologic response where discharge rapidly increases and decreases during a storm, along with higher peak storm discharges that may increase both erosion and transport of land surface, tributary, and stream sediments. The percentage of impervious area in the 13 study watersheds in 2012 ranged from 12.71 percent in the Richland Creek watershed to 52.43 percent in the North Fork Peachtree Creek watershed (table 6; fig. 10). Watershed impervious area is categorized into (1) transportation elements, which include land uses such as roads, parking lots, and driveways, and (2) building elements. On average, about two-thirds of the total impervious area in the watersheds is from transportation elements. High-density land use typically contains a large proportion of impervious area, hence, the strong association between these characteristics. The percentage of impervious area in the watersheds is associated more with high-density land use than with population density (fig. 11).

Figure 12 illustrates how the percentage of impervious area has changed over the time period 2000-14 in the 13 watersheds. Data were available for years 2000, 2005, 2006 and annually for 2008 to 2014 (Gwinnett County Department of Public Utilities, unpub. data, 2000-14). All 13 watersheds show increases in impervious area over the period 2000-14. The increases in impervious area for the LTTM program study area weighted by drainage area were 1.0 percent of the drainage area per year from 2000 to 2005 and 0.31 percent of the drainage area per year from 2005 to 2014. Although these increases are likely related to development within the watersheds associated with population growth (fig. 7), the decrease in the rate observed in the later 9 years did not match the pattern in population growth. The two watersheds with the highest percentage of impervious areas, North Fork Peachtree Creek and Crooked Creek, exhibited the lowest increases in impervious areas over the 14-year period, 0.05 and 0.14 percent per year, respectively. The Wheeler Creek watershed, which had the lowest percentage of impervious area (4.3 percent) of the 13 watersheds in 2000 , exhibited the highest rate of increase over the period ( 0.86 percent per year), indicating rapid development. Sweetwater Creek, Yellow River, Alcovy River, and Apalachee Creek watersheds also exhibited large increases in percentage of impervious areas over this same period, ranging from 0.64 to 0.70 percent per year. 
Table 6. Land use and watershed impervious area for 13 watersheds in Gwinnett County, Georgia, 2012.

[Land-use data from Atlanta Regional Commission, 2012]

\begin{tabular}{|c|c|c|c|c|c|c|c|c|c|c|c|}
\hline \multirow[b]{2}{*}{$\begin{array}{l}\text { Station } \\
\text { number }\end{array}$} & \multirow[b]{2}{*}{ Watershed name } & \multirow[b]{2}{*}{$\begin{array}{c}\text { Drainage } \\
\text { area } \\
\text { (square } \\
\text { miles) }\end{array}$} & \multicolumn{6}{|c|}{ Land use, percent } & \multicolumn{3}{|c|}{$\begin{array}{l}\text { Watershed impervious area } \\
\text { (percent) }\end{array}$} \\
\hline & & & 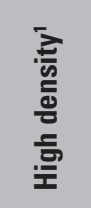 & $\begin{array}{l}\frac{1}{2} \\
\frac{1}{0} \\
\frac{2}{0} \\
3 \\
0 \\
0\end{array}$ & 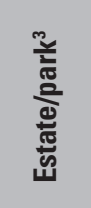 & 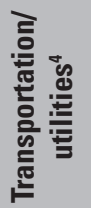 & 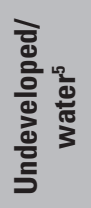 & 高 & 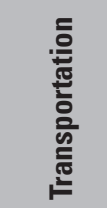 & 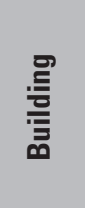 & సٓํㅁ \\
\hline 02205865 & Sweetwater Creek & 21.0 & 35.92 & 40.05 & 16.34 & 3.50 & 3.09 & 1.09 & 10.11 & 21.89 & 31.99 \\
\hline 02207120 & Yellow River & 161.4 & 25.93 & 56.36 & 12.13 & 1.18 & 2.88 & 1.92 & 8.82 & 16.82 & 25.64 \\
\hline 02207185 & No Business Creek & 10.1 & 14.40 & 64.01 & 19.25 & 0.10 & 1.48 & 0.75 & 6.07 & 12.69 & 18.75 \\
\hline 02207385 & Big Haynes Creek & 17.3 & 12.27 & 64.35 & 19.95 & 0.00 & 2.06 & 1.36 & 6.47 & 10.26 & 16.73 \\
\hline 02207400 & Brushy Fork Creek & 8.18 & 17.63 & 41.13 & 30.55 & 0.00 & 6.56 & 4.12 & 5.22 & 9.51 & 14.73 \\
\hline 02208150 & Alcovy River & 30.8 & 17.43 & 40.20 & 28.83 & 4.03 & 8.49 & 1.04 & 5.92 & 11.45 & 17.38 \\
\hline 02217274 & Wheeler Creek & 1.31 & 23.60 & 46.92 & 20.01 & 4.97 & 4.49 & 0.00 & 5.84 & 10.06 & 15.91 \\
\hline 02218565 & Apalachee River & 5.65 & 6.94 & 64.43 & 25.74 & 0.00 & 2.88 & 0.00 & 7.19 & 10.32 & 17.51 \\
\hline 02334480 & Richland Creek & 9.37 & 12.71 & 37.72 & 27.97 & 2.33 & 19.18 & 0.09 & 4.37 & 8.34 & 12.71 \\
\hline 02334578 & Level Creek & 5.06 & 17.96 & 48.00 & 30.66 & 0.00 & 3.38 & 0.00 & 6.36 & 10.36 & 16.72 \\
\hline 02334885 & Suwanee Creek & 47.1 & 22.37 & 35.53 & 30.27 & 3.24 & 7.50 & 1.09 & 6.49 & 12.94 & 19.42 \\
\hline 02335350 & Crooked Creek & 8.87 & 45.00 & 37.98 & 8.23 & 4.67 & 3.88 & 0.23 & 12.73 & 24.41 & 37.14 \\
\hline 02336030 & $\begin{array}{l}\text { North Fork Peachtree } \\
\text { Creek }\end{array}$ & 1.53 & 60.59 & 31.80 & 1.13 & 5.51 & 0.96 & 0.00 & 20.02 & 32.41 & 52.43 \\
\hline \multicolumn{2}{|c|}{ LTTM program study area } & 306.6 & 22.99 & 50.58 & 18.67 & 1.78 & 4.70 & 1.50 & 7.80 & 14.77 & 22.57 \\
\hline
\end{tabular}

${ }^{1}$ High-density land use includes commercial, industrial, schools, religions, quarries, and residential lots with less than 1/4 acre.

${ }^{2}$ Low-density land use includes residential lot sizes greater than or equal to $1 / 4$ acre and less than 5 acres.

${ }^{3}$ Estate/park use includes public and private parks, golf courses, agricultural lands, and forests.

${ }^{4}$ Transportation/utilities land use includes pervious and impervious areas within the right-of-way for roads, railroads, communications, and utilities.

${ }^{5}$ Undeveloped land use includes landfills, waste dumps, water control structures, and recently cleared transitional land. Water land use includes reservoirs and wetlands.

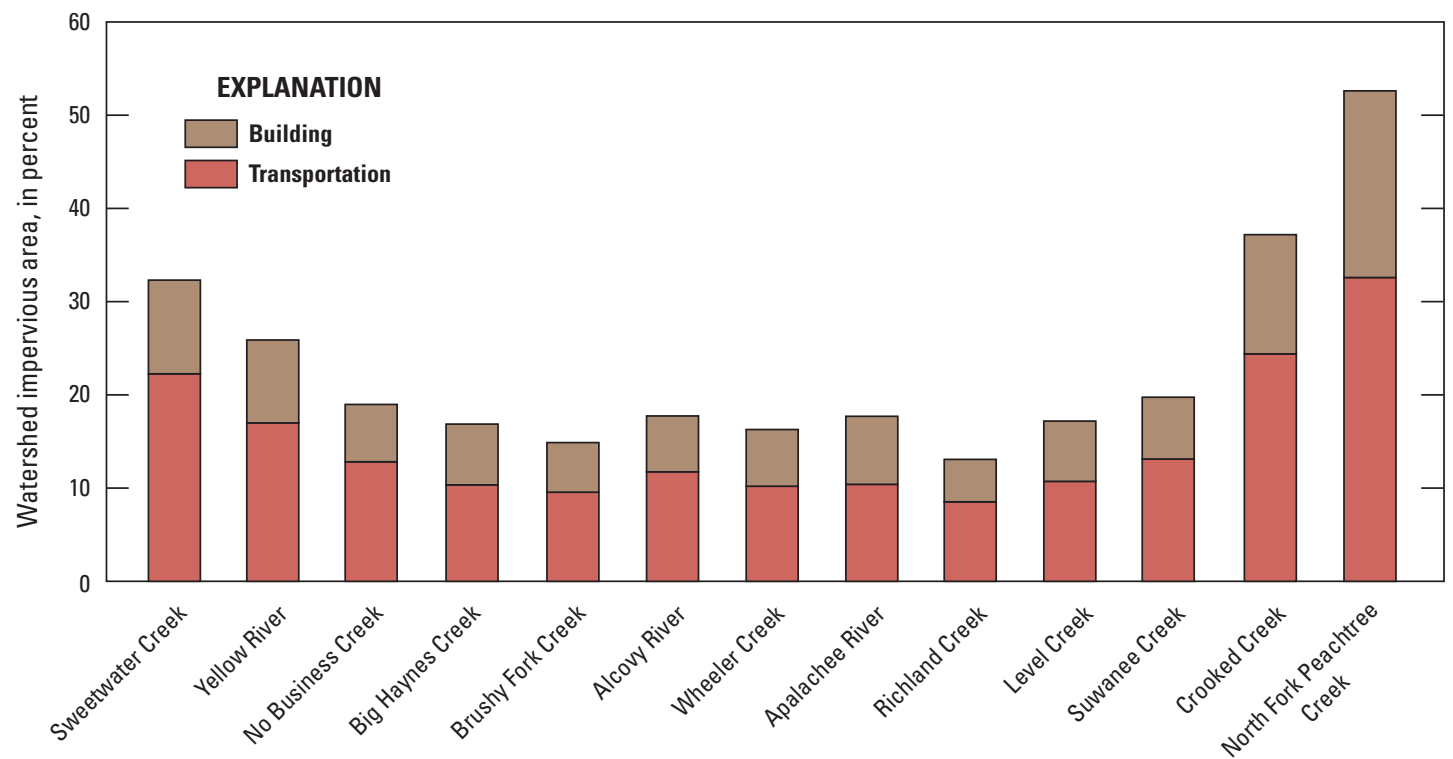

Figure 10. Percentage of watershed impervious area from transportation and building land use for 13 monitored watersheds in Gwinnett County, Georgia, 2012. Data from Gwinnett County land coverage data, Gwinnett County Department of Public Utilities, unpub. data, 2012. 

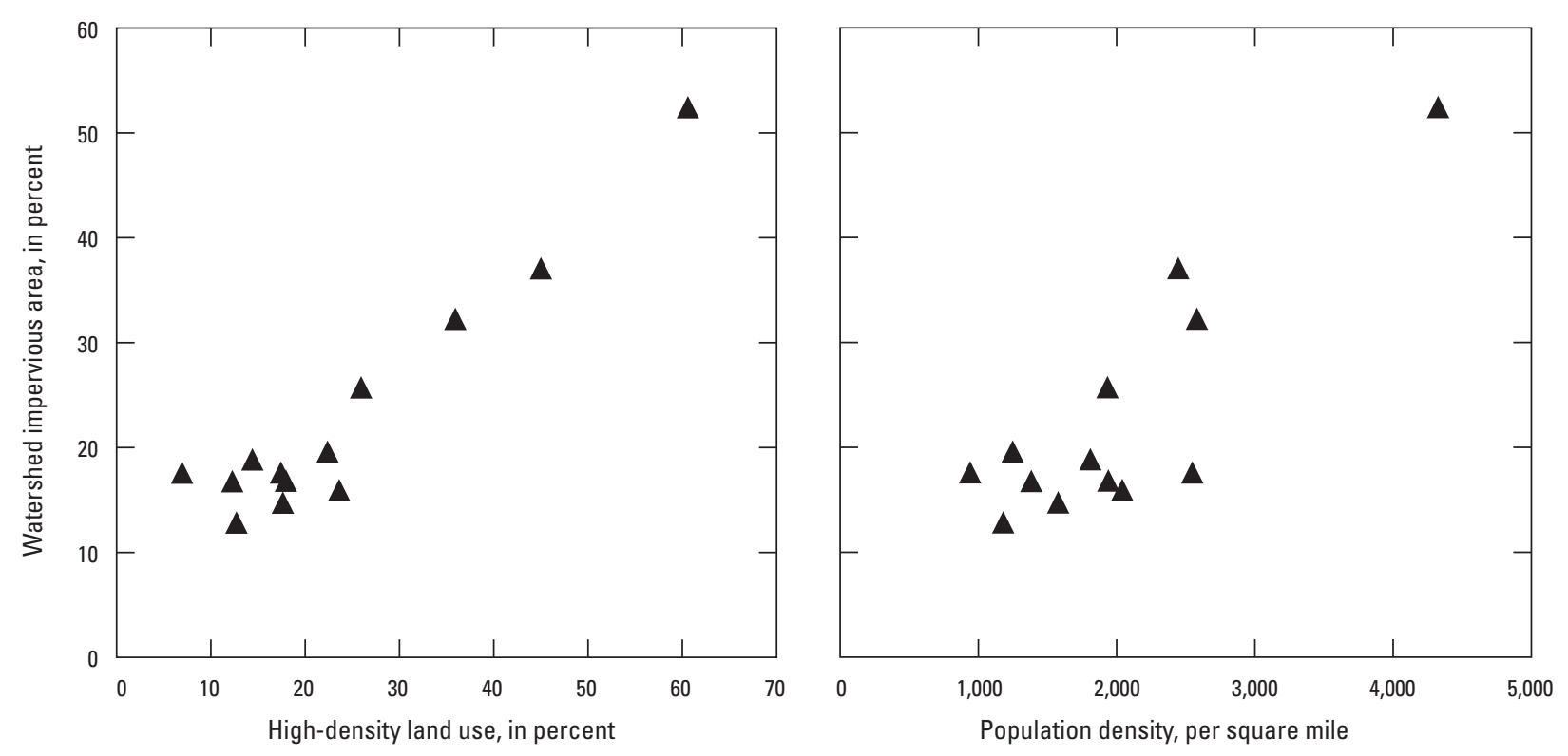

Figure 11. Watershed impervious area as related to $(A)$ high-density land use and $(B)$ population density for 13 monitored watersheds in Gwinnett County, Georgia, 2013. Impervious area from Gwinnett County landcoverage data, Gwinnett County Department of Public Utilities, unpub. data 2013; population data derived from American community survey 5-year estimates of 2009-13 block group data, U.S. Census Bureau, 2014.

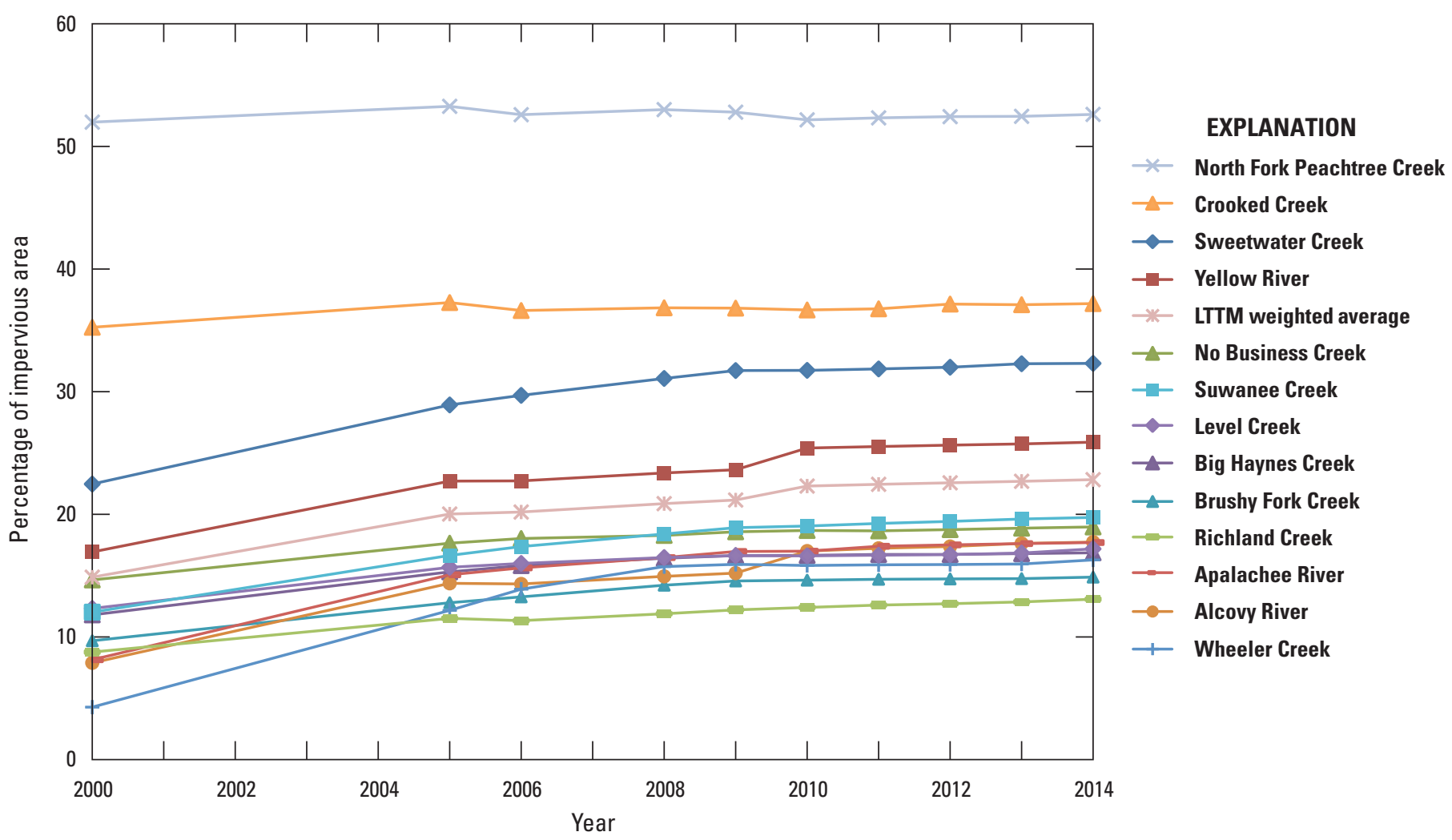

Figure 12. Percentage of impervious area in 13 monitored watersheds in Gwinnett County, Georgia. The LTTM program weighted average represents the spatial average of the area of the monitored watersheds. Data from Gwinnett County land-cover data, Gwinnett County Department of Public Utilities, unpub. data, 2000-14. 


\section{Hydrologic Budgets}

The components of water budgets include precipitation, stream runoff, evapotranspiration (ET), and groundwater inputs, outputs, and storage; of which precipitation and runoff are measured as part of the LTTM program. Annual and monthly average precipitation and runoff were computed for the 13 watersheds in the study area using the measured data. The measured precipitation and runoff data were also used to compute flow duration curves, base flow, and runoff ratios for the 13 watersheds. Variations in runoff between the watersheds can be the result of differences in precipitation and watershed characteristics. Droughts and wet conditions also have large effects on water budgets, and the effects of these conditions on runoff, groundwater storage, and runoff ratios are discussed.

\section{Climate and Precipitation}

Gwinnett County has a humid, subtropical climate characterized by warm, humid summers and cool, wet winters. Monthly average air temperatures range from 42.2 degrees Fahrenheit $\left({ }^{\circ} \mathrm{F}\right)$ in January to $79.8^{\circ} \mathrm{F}$ in July (1981-2010 thirty-year average for Atlanta Dekalb Peachtree Airport station USW00053863, National Oceanic and Atmospheric Administration, 2014; nearest air temperature station, in adjacent Dekalb
County). Mean annual precipitation is 54.7 inches (1981-2010 thirty-year average for Norcross station USC00096407, National Oceanic and Atmospheric Administration, 2014; in western portion of Gwinnett County). Precipitation is fairly evenly distributed throughout the year with the fall having the lowest amount of precipitation. Winter rainstorms are characterized by long duration, evenly distributed, and typically low-intensity frontal systems. In contrast, spring and summer rainstorms are characterized by short duration, unevenly distributed, intense convective thunderstorms. Despite their short duration, the intensity of these rainstorms often result in higher peak streamflows in headwater watersheds than those observed for longer-duration, low-intensity storms. Higher peak streamflows may result in increased erosion and washoff of constituents. Mean annual ET is estimated to account for about 50 to 60 percent of the annual precipitation in the study area (Sanford and Selnick, 2013). Evapotranspiration is highest in the summer as the result of temperature and solar radiation being at their peak. The seasonal pattern of ET results in declining base flows and groundwater storage throughout the growing season (April-September) as well as progressively increasing base flows and groundwater storage from event recharge during the dormant season.

The annual precipitation totals for WYs 2002-15 for the 13 study watersheds are shown in figure 13 . The WYs 2002-15 annual average for the LTTM program

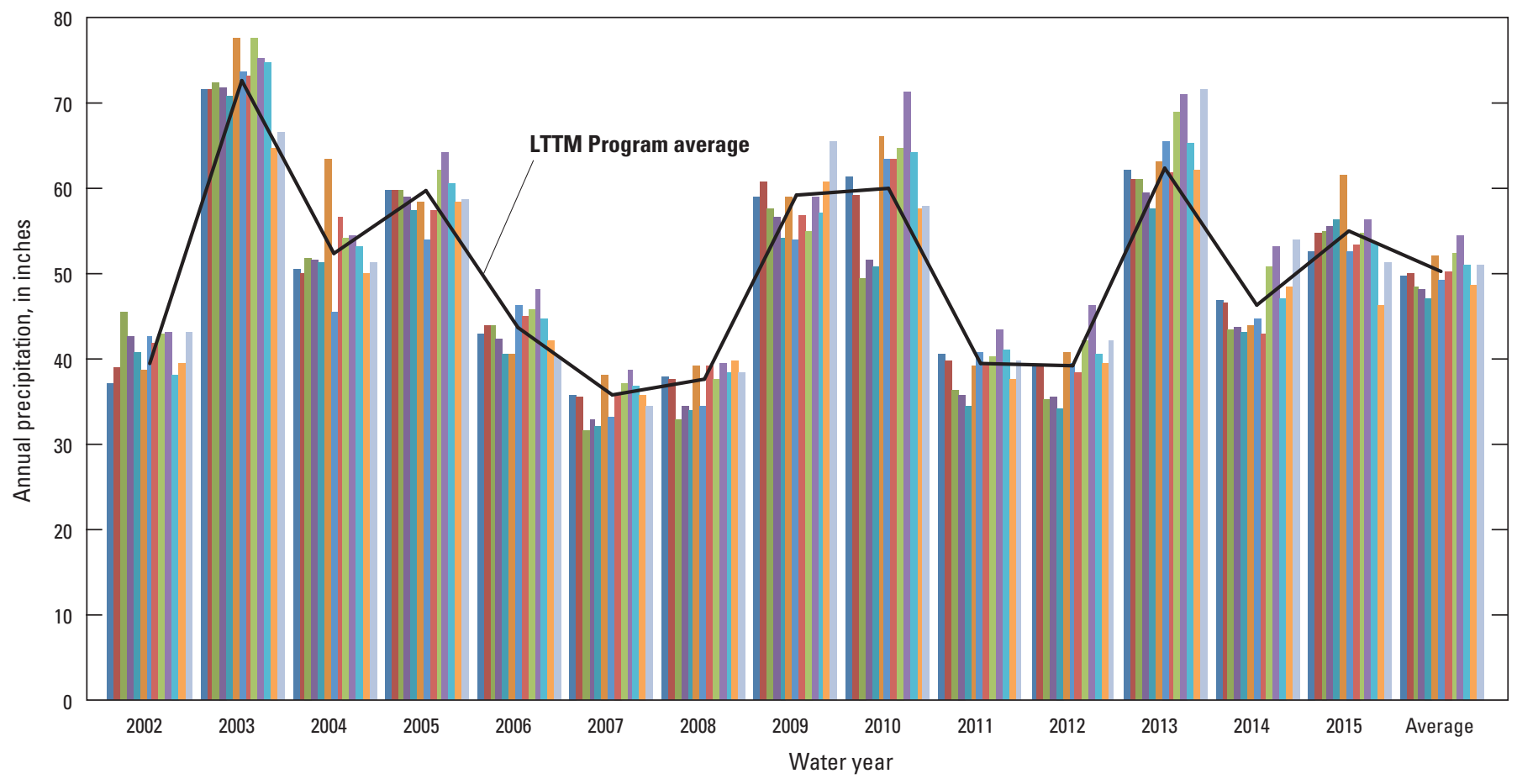

Figure 13. Annual precipitation totals for each of the 13 monitored watersheds in Gwinnett County, Georgia, for water years 2002-15. The LTTM program average represents the spatial average of the area of the monitored watersheds.

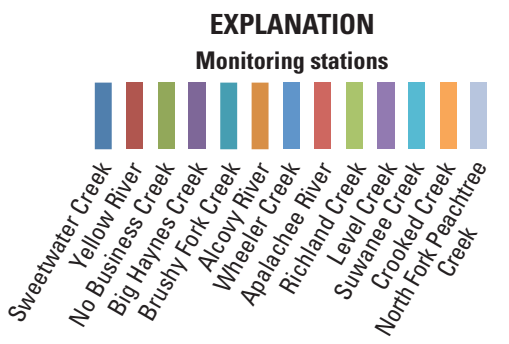


study area was 50.2 inches, which was below the long-term average of 54.7 inches reported at Norcross, Georgia. Annual precipitation ranged from a low of 35.7 inches (WY 2007) to a high of 72.7 inches (WY 2003). Five years were dry, with precipitation $<40$ inches (WYs 2002, 2007, 2008, 2011, and 2012), and 5 years were fairly to very wet, with precipitation $>59$ inches (WYs 2003, 2005, 2009, 2010, and 2013).

Variability in spatial patterns in precipitation can be due to factors such as topography (McCrary, 2011), the variable distribution of precipitation from convective thunderstorms, and proximity and orientation to urban heat islands (Bornstein and Lin, 2000; Dixon and Mote, 2003; Mote and others, 2007; Shem and Shepherd, 2009) such as nearby Atlanta. Precipitation for WYs 2002-15 was highest in watersheds in the northern part of the county where altitudes are the highest (fig. 3; Alcovy River, Richland Creek, and Level Creek watersheds; 52.1, 52.4, and 54.5 inches per year [in/yr], respectively) and was lowest in watersheds in the southern part of the county where altitudes are lower (No Business Creek, Big Haynes Creek, and Brushy Fork Creek watersheds; $48.3,48.1$, and $47.0 \mathrm{in} / \mathrm{yr}$, respectively). It is important to consider the variations in precipitation among the 13 LTTM program watersheds when comparing the resulting stream runoff among watersheds. Nevertheless, spatial variability in precipitation observed between watersheds is much smaller than the temporal variations between years.

Monthly average precipitation for WYs 2002-15 ranged from 3.3 inches (April) to 5.4 inches (July; fig. 14). Precipitation did not vary strongly with seasons. The lowest values were observed in April, October, and November $(3.3,3.5$, and 3.7 inches, respectively), and the highest values were observed in March, July, and December (4.6, 5.4, and 4.7 inches, respectively).

\section{Runoff}

In this report, runoff (the volume of streamflow) was divided by the area of each watershed and was expressed as a depth in units of inches. This convention allows comparison of runoff values between watersheds with different sized drainage areas and accommodates direct comparison with precipitation and is similar to the distinction in use of load versus yield with respect to contaminants. Runoff "depth" herein is referred to as specific discharge. Runoff for the period WYs 2002-15 averaged $21.5 \mathrm{in} / \mathrm{yr}$ for the LTTM program study area (fig. 15). Annual runoff varied greatly, from a low of 11.1 inches (WY 2012) to a high of 38.7 inches

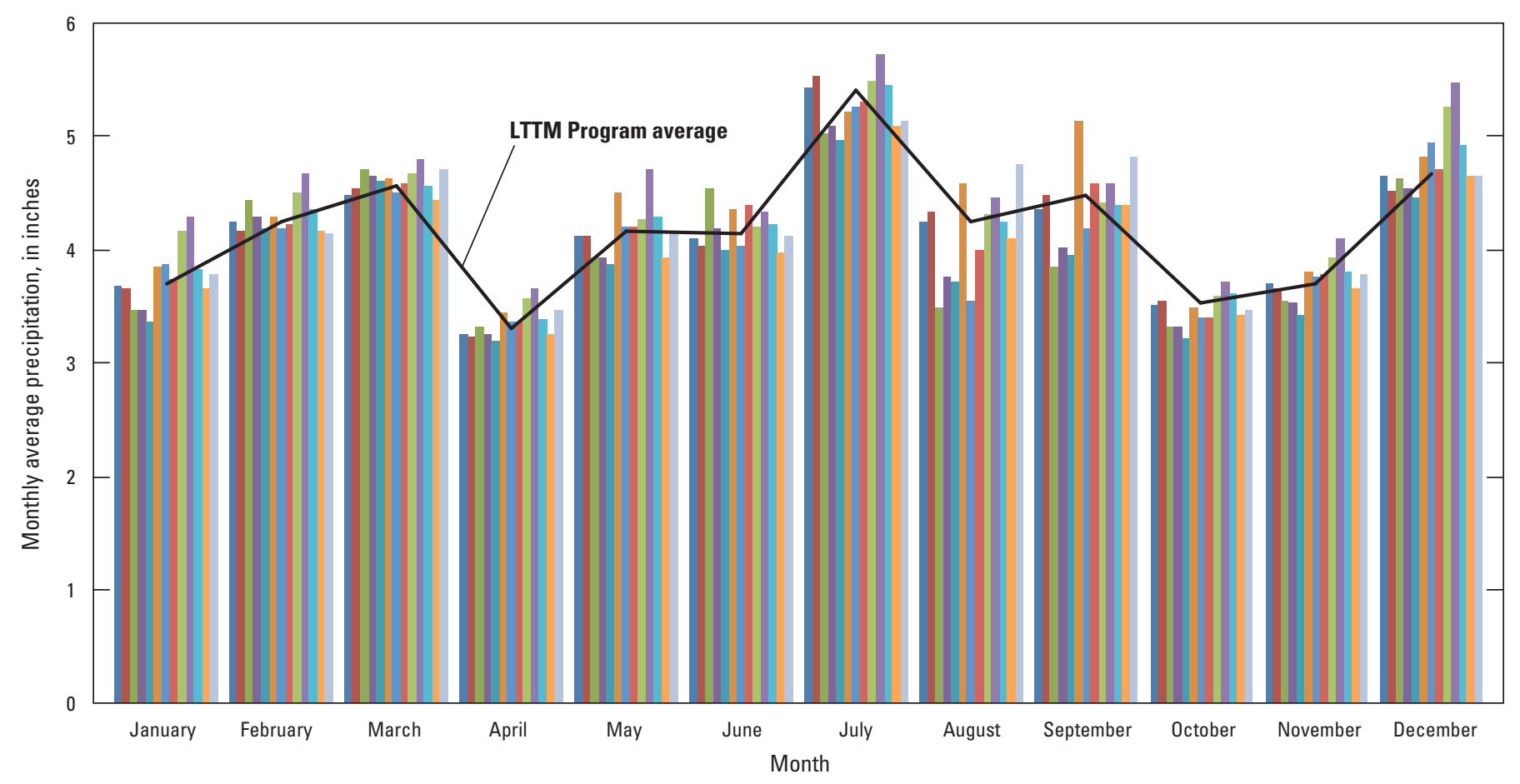

Figure 14. Monthly average precipitation for each of the 13 monitored watersheds in Gwinnett County, Georgia, for water years 2002-15. The LTTM program average represents the spatial average of the area of the monitored watersheds.

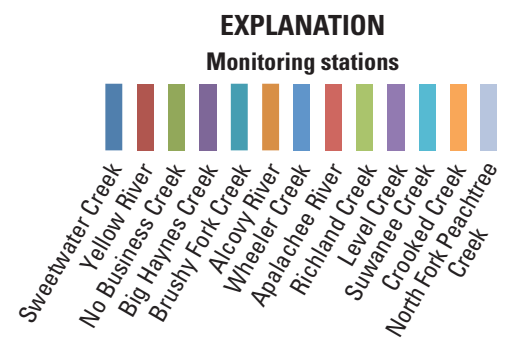


(WY 2003), a range of 27.6 inches. Runoffs during the period were lowest in the No Business Creek, Big Haynes Creek, and Brushy Fork Creek watersheds (19.0, 19.1, and $19.1 \mathrm{in} / \mathrm{yr}$, respectively), which was at least partially due to the lower amounts of precipitation in this part of the county (fig. 13). Runoffs were highest in the Crooked Creek and North Fork Peachtree Creek watersheds (24.8 and $29.3 \mathrm{in} / \mathrm{yr}$, respectively). The variability in annual runoff between years was greater than the variability in annual runoff between individual watersheds for a given year, indicating that the variability in precipitation and possibly other components of the water budget were more important in controlling annual variability in runoff than differences in watershed characteristics. Hence, when determining the relations between runoff and watershed characteristics, it is important to make these comparisons for the same period, and also to take into account any spatial variations in precipitation.

The year-to-year variations in annual runoff (fig. 15) follows the overall pattern for annual precipitation (fig. 13), but the variability in runoff is more pronounced as indicated by a higher relative standard error for runoff $(0.44)$ than for precipitation (0.23). Relative standard error is a statistic that can be used to measure the variability of a variable with respect to its mean value and is calculated as its standard deviation divided by its mean. This higher variability in annual runoff reflects the effects of other components of the water budget, ET and storage.

Although groundwater storage was not quantified in this study, the effects of variations in groundwater storage can be observed in the patterns in annual runoff. The effect of prior groundwater storage level on current runoff is referred to as watershed memory (Nippgen and others, 2016). For example, during the drought of WYs 2011-12, while the LTTM program study area annual precipitation were similar in both years (39.4 and 39.2 inches in WYs 2011 and 2012, respectively), annual runoff declined from 15.1 inches (WY 2011) to 11.1 inches (WY 2012). Much of this difference is likely the result of a smaller contribution of stream base flow from depleted groundwater storage in WY 2012. The effects of storage on runoff can also be observed in WYs 2005 and 2009 for the LTTM program study area. While these years had similar amounts of precipitation, 59.6 (WY 2005) and 59.1 (WY 2009) inches, WY 2009 had much lower runoff than WY 2005, 23.5 versus 32.9 inches, respectively. Much of this apparent discrepancy was likely the result of a larger portion of precipitation recharging (replenishing) groundwater storage in WY 2009, while a larger portion of precipitation resulted in runoff in WY 2005. This occurred because groundwater

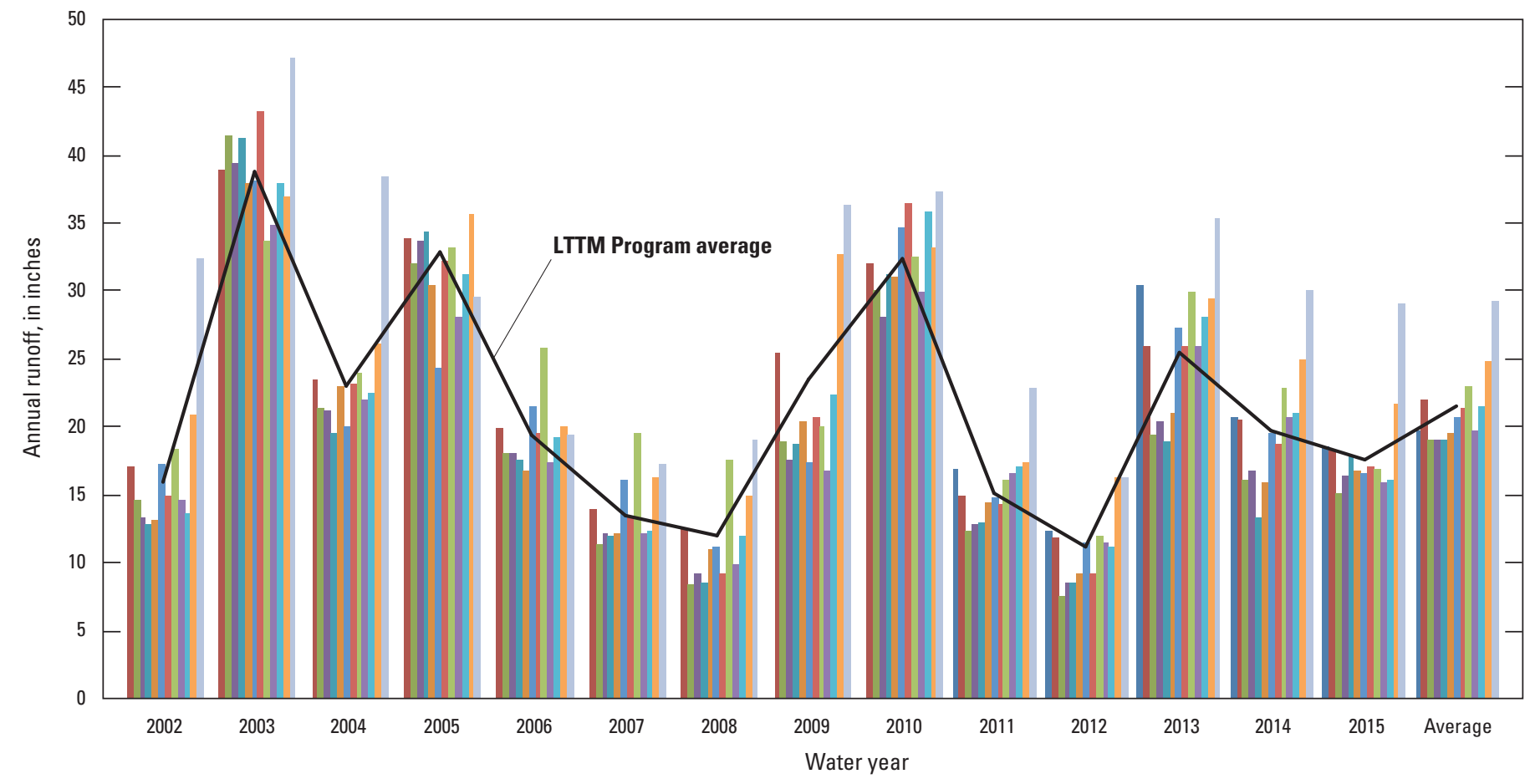

Figure 15. Annual runoff for each of the 13 monitored watersheds in Gwinnett County, Georgia, for water years 2002-15. The LTTM program average represents the spatial average of the area of the monitored watersheds. Sweetwater Creek watershed runoff data are available only for water years 2011-15.

EXPLANATION

Monitoring stations

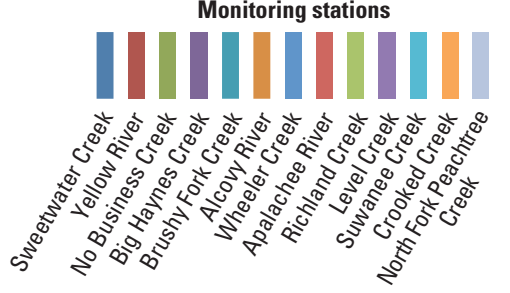


storage started out lower in WY 2009, following a 2-year drought in WYs 2007-08, compared to WY 2005, which followed a year with more average hydrologic conditions.

The LTTM program study area annual runoff was used to categorize annual watershed wetness conditions as dry, average, or wet, which are then related to variations in waterquality loads and yields later in the report. Although annual patterns in both precipitation (fig. 13) and runoff (fig. 15) were related to periods of drought, runoff was selected for analysis because it incorporates the effects of groundwater storage conditions, which is an important aspect of drought. Five WYs were categorized as dry (WYs 2002, 2007-08, and 2011-12; runoff 11.1-15.9 inches), six as average (WYs 2004, 2006, 2009, and 2013-15; runoff 17.6-25.4 inches), and three as wet (WYs 2003, 2005, and 2010; runoff 32.3-38.7 inches). The five WYs categorized as dry corresponded well with weekly estimates of drought severity in Gwinnett County as classified by the U.S. Drought Monitor (2014 and 2016; fig. 16). Droughts were persistent in all five of these WYs, with moderate to extreme drought conditions observed in WYs 2002 and 2011-12 (annual runoff 11.1-15.8 inches) and moderate to exceptional drought conditions observed in WYs 2007-08 (annual runoff 12.0-13.4 inches).

Monthly average runoff for the LTTM program study area for the period of study was lowest in August (1.2 inches) and highest in March (2.6 inches; fig. 17). Patterns in monthly average runoff reflect the effects of seasonal patterns in groundwater storage and ET components of the water budget. Monthly average runoff increased sequentially from October to March, with the exception of a slight decline between December and January. This period corresponds to the dormant season when potential evapotranspiration (PET) is low and precipitation typically exceeds PET, with some of this excess resulting in groundwater recharge. Potential ET represents the theoretical amount of ET that occurs when surface soil conditions are saturated (wet). Actual ET is less than PET when there is not enough water available to evapotranspire. Potential ET varies seasonally and is highest in summer due to higher air temperatures and inputs of solar radiation that provide the energy for evapotranspiration. The progressive increase in runoff observed during the dormant season was the result of a combination of increases in stream base flow and higher storm runoff, in response to increasing groundwater storage and wetter shallow soil moisture conditions.

Monthly average runoff decreased rapidly from March to April and then exhibited a less rapid, but overall decline through the summer and into October. This period represents the growing season, when high rates of PET typically exceed precipitation, resulting in precipitation being evapotranspired from shallow soils and precluding much groundwater recharge. The rapid decline in runoff from March to April is likely due to a combination of (1) low precipitation in April (fig. 14) that limited storm runoff, (2) decreases in storm runoff due to drier soil moisture conditions, and (3) rapid decreases in base flow. The rapid decreases in observed base flow were due to a combination of declines in groundwater storage, attributed to losses from base flow and ET, and the lack of groundwater recharge from the combination of low April precipitation and high PET.

Continued declines in monthly average runoff during the remainder of the growing season were associated with the same processes mentioned above for the March to April runoff decline. Runoff declines were slower because releases of stream base flow from storage become less rapid as groundwater levels decline. Furthermore, as groundwater storage continues to decline, ET can become limited by the availability of shallower groundwater that can be evapotranspired, thereby limiting the amount of losses of groundwater storage from ET and the rate of subsequent base-flow declines later in the season. Some of the variability observed in the overall declines in monthly average runoff was associated with higher amounts of precipitation that likely temporarily exceeded PET

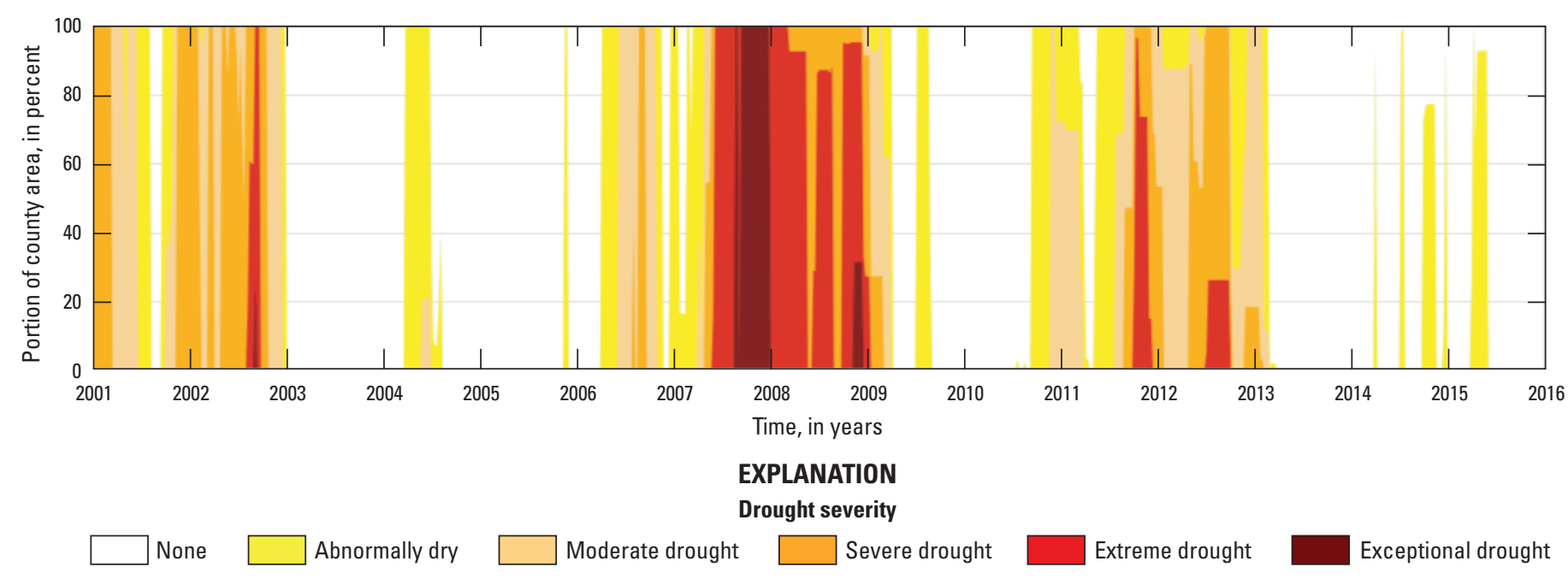

Figure 16. Weekly drought severity in Gwinnett County, Georgia, for years 2001-15 as a portion of county area. Modified from U.S. Drought Monitor, 2016. 


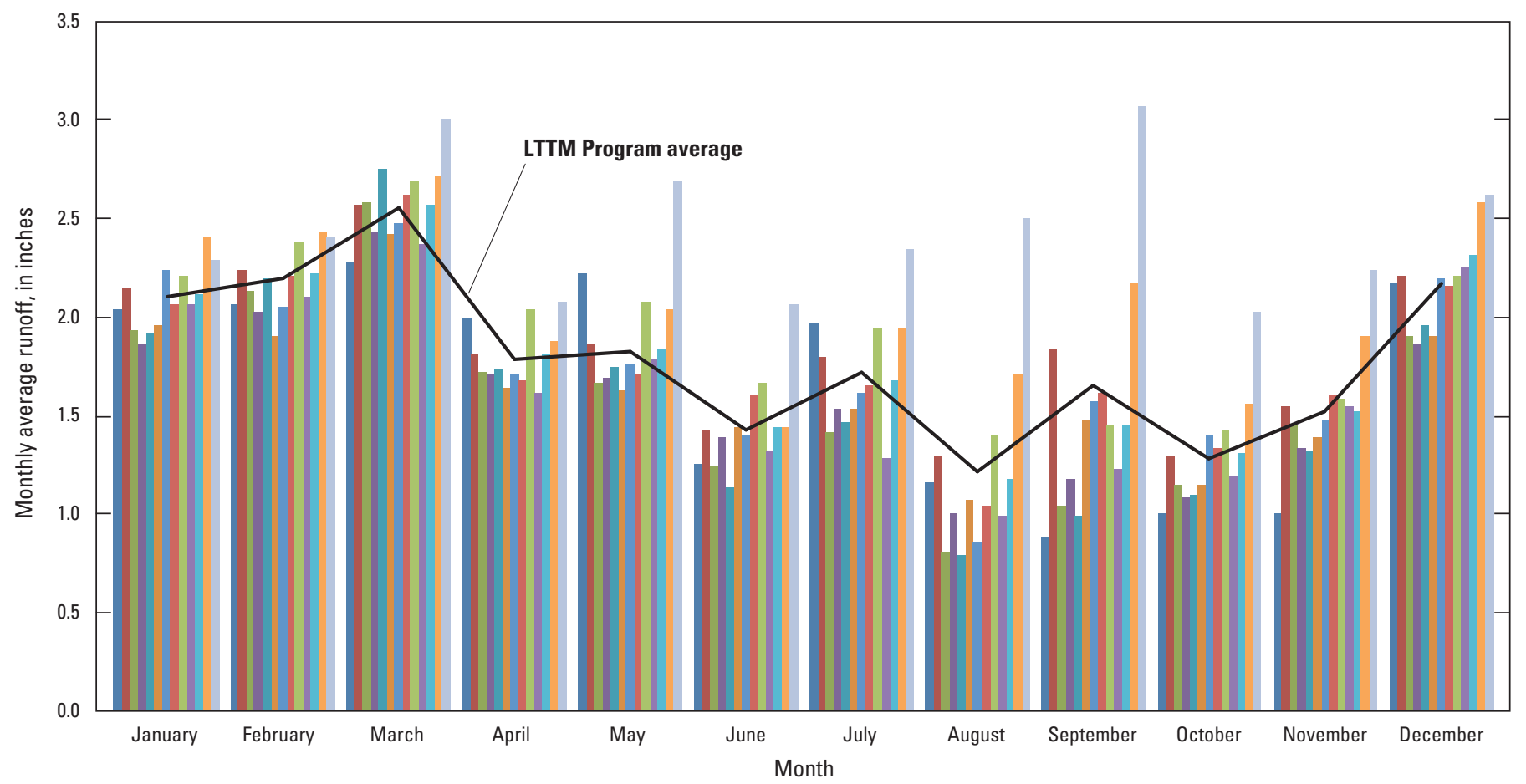

\begin{abstract}
Figure 17. Average monthly runoff for each of the 13 monitored watersheds in Gwinnett County, Georgia, for water years 2002-15. The LTTM program average represents the spatial average of the area of the monitored watersheds. Sweetwater Creek watershed averages are for water years 2011-15.
\end{abstract}

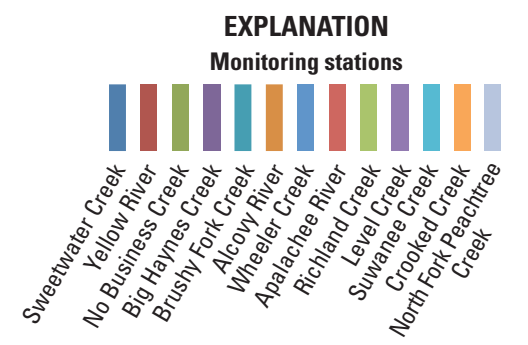

and resulted in groundwater recharge and increased runoff. For example, July had the highest monthly average precipitation observed (5.4 inches; fig. 14) and also had a higher monthly average runoff (1.7 inches) than its adjacent months. A similar increase in monthly average runoff was observed in September, which had both higher monthly average precipitation (4.5 inches) and runoff ( 1.6 inches) than its adjacent months. Although precipitation was less in September than in July, September generated a similar amount of runoff likely because PET was also lower in September than in July. In summary, in the dormant season, precipitation in excess of PET results in recharge of groundwater storage, increased base flow, and more storm runoff, while in the growing season, a larger portion of precipitation results in ET.

\section{Flow Duration Curves}

The streamflow duration curves were compared across watersheds by plotting the cumulative percentile of streamflow for each watershed for WYs 2002-15 (fig. 18). These curves were generated from the daily average streamflows. This graph allows for watershed comparisons of not only the range of streamflows observed, but also the cumulative temporal frequency at which a particular flow occurs. For example, the streamflow with a cumulative frequency of 40 percent indicates that streamflow occurred at this discharge (flow rate) or lower for 40 percent of the period. Streamflows below cumulative percentiles of approximately 80 percent generally represent days with base-flow conditions, while streamflows above 80 percent generally represent days with storm conditions.

The flow duration curves were fairly similar for most watersheds in the 20 to 85 percent cumulative percentile range. Distributions exhibited more variability between watersheds below the 20th percentile than above the 85th percentile. Comparisons with the Sweetwater Creek watershed were not considered because its distribution represents a shorter period (WYs 2011-15) during which the station was monitored that had drier conditions than the longer period (WYs 2002-15) for the other watersheds. No Business Creek, Brushy Fork Creek, and Wheeler Creek watersheds had the lowest base flows. Lower base flows in the No Business Creek and Brushy Fork Creek watersheds may be related to lower amounts of precipitation that were observed in that region of the county (fig. 13) and to lower basin slopes (figs. 4 and 5). Yellow River, Big Haynes Creek, and Richland Creek had the highest base flows. The Richland Creek watershed, which had the highest base 


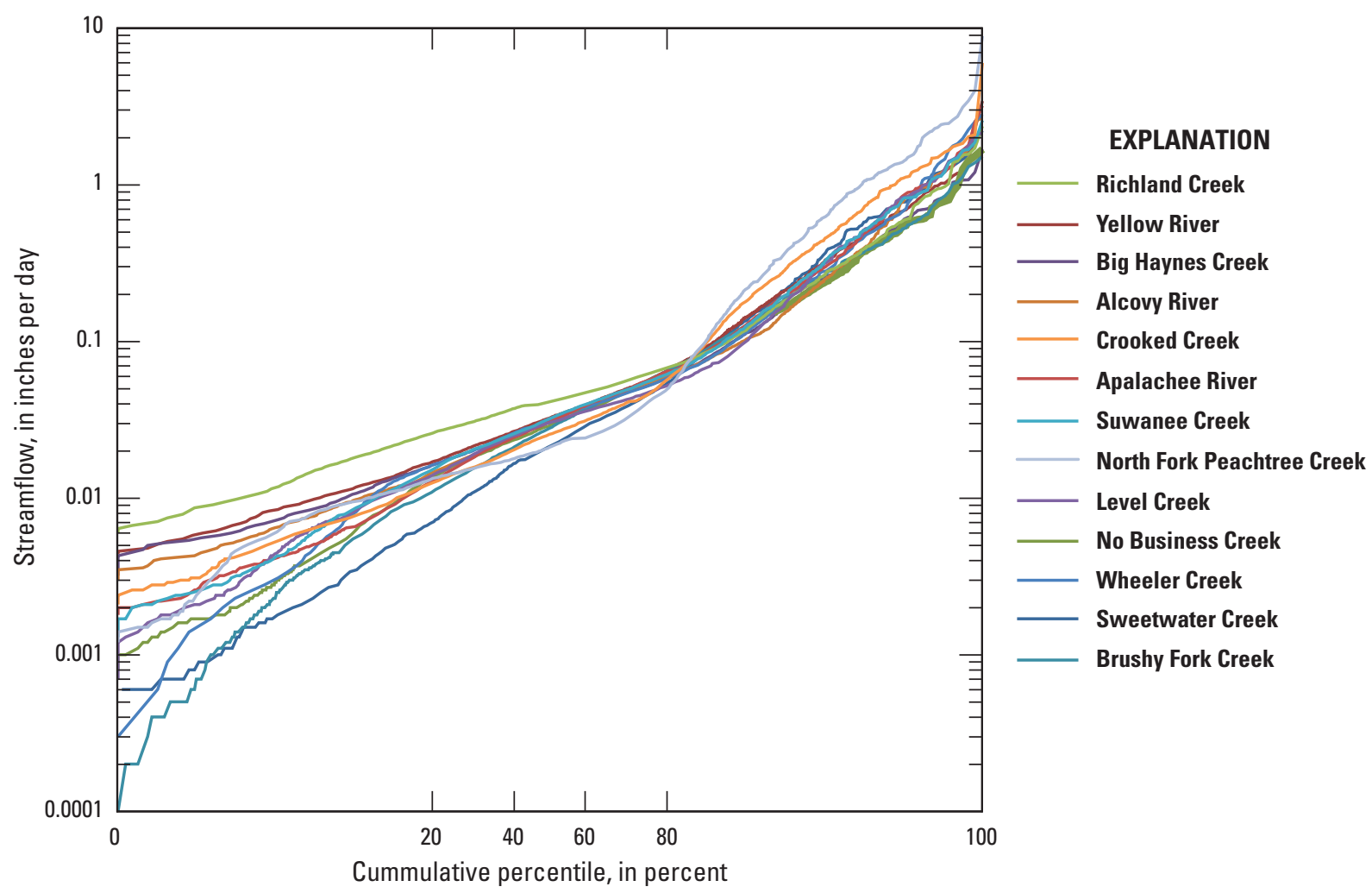

Figure 18. Streamflow duration curves for each of the 13 monitored watersheds in Gwinnett County, Georgia, for water years 2002-15. Cumulative percentiles plotted on a probability scale. Sweetwater Creek watershed runoff data are available only for water years 2011-15.

flows of all the watersheds, also was the watershed with the highest basin slope, the lowest percentage of impervious area (fig. 10), and the second highest amount of precipitation. No Business Creek, Big Haynes Creek, and Brushy Fork Creek watersheds had the three lowest stormflows. These watersheds were in the region of the county with the lowest precipitation and also had three of the four lowest basin slopes. The Brushy Fork watershed also had the second lowest percentage of impervious area. Apalachee River and North Fork Peachtree Creek watersheds had the highest stormflows; North Fork Peachtree Creek watershed had the highest percentage of watershed impervious area.

Flow duration curves are affected by hydrologic conditions, as illustrated in figure 19 for the Yellow River watershed. The three curves represent various years with the three hydrologic conditions (wet, average, and dry) as previously defined from annual runoff. The three curves generally parallel each other, with higher flows for the same cumulative percentiles as hydrologic conditions become wetter. Similar patterns with hydrologic conditions are observed seasonally. This illustrates the importance of comparing distributions for periods that experience the same climatic conditions.

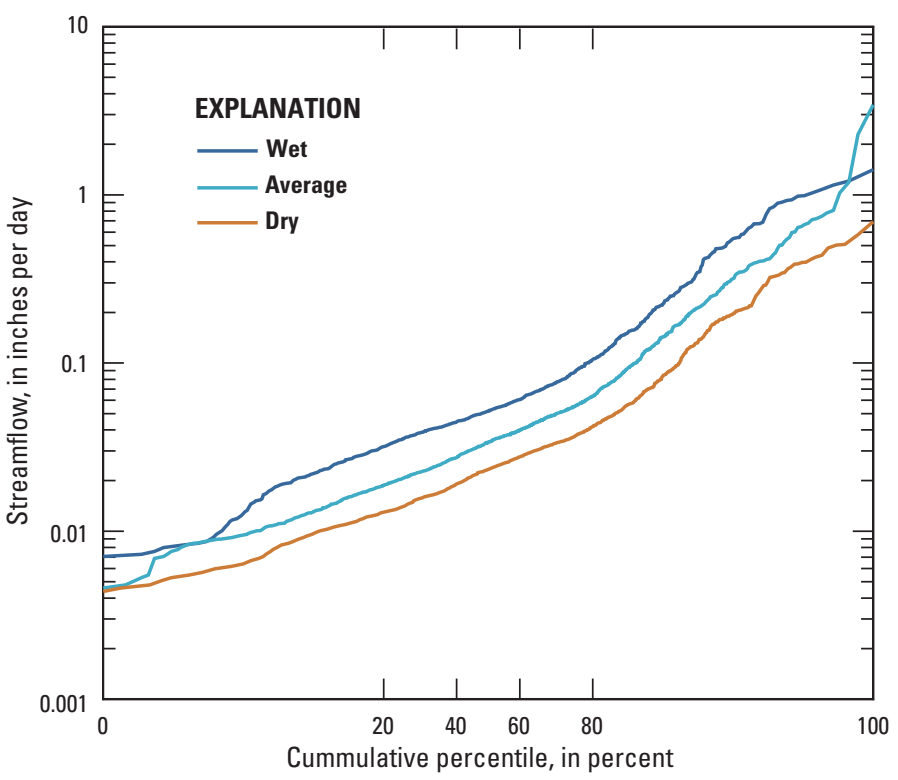

Figure 19. Streamflow duration curves for the Yellow River watershed for wet (water years 2003, 2005, and 2010), average (water years 2004, 2006, 2009, and 2013-15), and dry (water years 2002, 2007-08, and 2011-12) years. Cumulative percentiles are plotted on a probability scale. 


\section{Base Flow}

The results of the hydrograph separation into base-flow and stormflow components tell a somewhat different story than the flow duration curve plots (table 7). Sweetwater Creek, Crooked Creek, and North Fork Peachtree Creek watersheds had the lowest base-flow runoff of the 13 watersheds. Note that Sweetwater Creek was reported for a shorter drier period, WYs 2011-15. Base-flow runoff was highest at Richland Creek, the watershed with the steepest basin slope. Base-flow index (BFI), calculated as base-flow runoff divided by total runoff, was lowest for the North Fork Peachtree Creek watershed (0.257), which had the highest stormflows as indicated by the flow duration curves plot (fig. 18) and also had the highest percentage of watershed impervious area (table 6). The highest BFI was for the Richland Creek watershed. There is a strong relation of base-flow runoff and BFI with the percentage of impervious area in a watershed $\left(\mathrm{R}^{2} \mathrm{~s}\right.$ of 0.62 and 0.89 , respectively; fig. 20), with a stronger relation for BFI, which indicates that impervious area not only affects the amount of base flow but also the amount of base flow relative to stormflow. Increases in impervious area are known to decrease base flows while also increasing stormflows and this has been shown to occur in urbanized areas in the nearby Atlanta, Ga. area (Rose and Peters, 2001; Calhoun and others, 2003). Increases in base-flow concentrations can result from reductions in base-flow runoff while stream point-source and waste-load allocation contributions remain steady due to the reductions in runoff volume diluting these inputs.

\section{Runoff Ratios}

Runoff ratios (also known as water yields) represent the portion of precipitation that results in runoff as opposed to being evapotranspired. The runoff ratios were calculated as the percentage of runoff relative to precipitation (fig. 21). The runoff ratio removes much of the variability in runoff due to variations in the amount of precipitation among years, months, and watersheds. Variability in the runoff ratio can be the result of differences in the amounts of stream base flow and storm runoff, groundwater storage, and ET and can reflect differences in both hydrologic conditions and watershed characteristics. The runoff ratio for WYs 2002-15 was 42.8 percent for the LTTM program study area. Assuming that the effects of changes in groundwater storage on the water budget become negligible over longer periods of time, this runoff ratio indicates that ET represents 57.2 percent of the long-term water budget. Annual runoff ratios varied from a minimum of 28.4 percent (WY 2012) to a maximum of 55.1 percent (WY 2005). Annual runoff ratios were low in 6 years ( $\leq 40.0$ percent; WYs 2002, 2007-08, 2011-12, and 2015) and high in 3 years (53.2-55.1 percent; WYs 2003, 2005, and 2010). These low and high years generally correspond with the dry and wet year hydrologic conditions previously categorized using annual runoff.
Table 7. Average base-flow runoff and base-flow index (baseflow runoff divided by total runoff) for 13 watersheds in Gwinnett County, Georgia, for water years 2002-15.

\begin{tabular}{|c|c|c|c|}
\hline $\begin{array}{l}\text { Station } \\
\text { number }\end{array}$ & Watershed & $\begin{array}{l}\text { Base-flow runoff } \\
\text { (inches per day) }\end{array}$ & $\begin{array}{l}\text { Base-flow } \\
\text { index }\end{array}$ \\
\hline 02205865 & Sweetwater Creek ${ }^{1}$ & 0.019 & 0.356 \\
\hline 02207120 & Yellow River & 0.030 & 0.503 \\
\hline 02207185 & No Business Creek & 0.030 & 0.571 \\
\hline 02207385 & Big Haynes Creek & 0.032 & 0.608 \\
\hline 02207400 & Brushy Fork Creek & 0.029 & 0.563 \\
\hline 02208150 & Alcovy River & 0.030 & 0.553 \\
\hline 02217274 & Wheeler Creek & 0.030 & 0.536 \\
\hline 02218565 & Apalachee River & 0.029 & 0.505 \\
\hline 02334480 & Richland Creek & 0.039 & 0.624 \\
\hline 02334578 & Level Creek & 0.028 & 0.513 \\
\hline 02334885 & Suwanee Creek & 0.029 & 0.501 \\
\hline 02335350 & Crooked Creek & 0.023 & 0.338 \\
\hline 02336030 & $\begin{array}{l}\text { North Fork Peachtree } \\
\text { Creek }\end{array}$ & 0.021 & 0.257 \\
\hline
\end{tabular}

${ }^{1}$ Sweetwater Creek watershed for water years 2011-15.
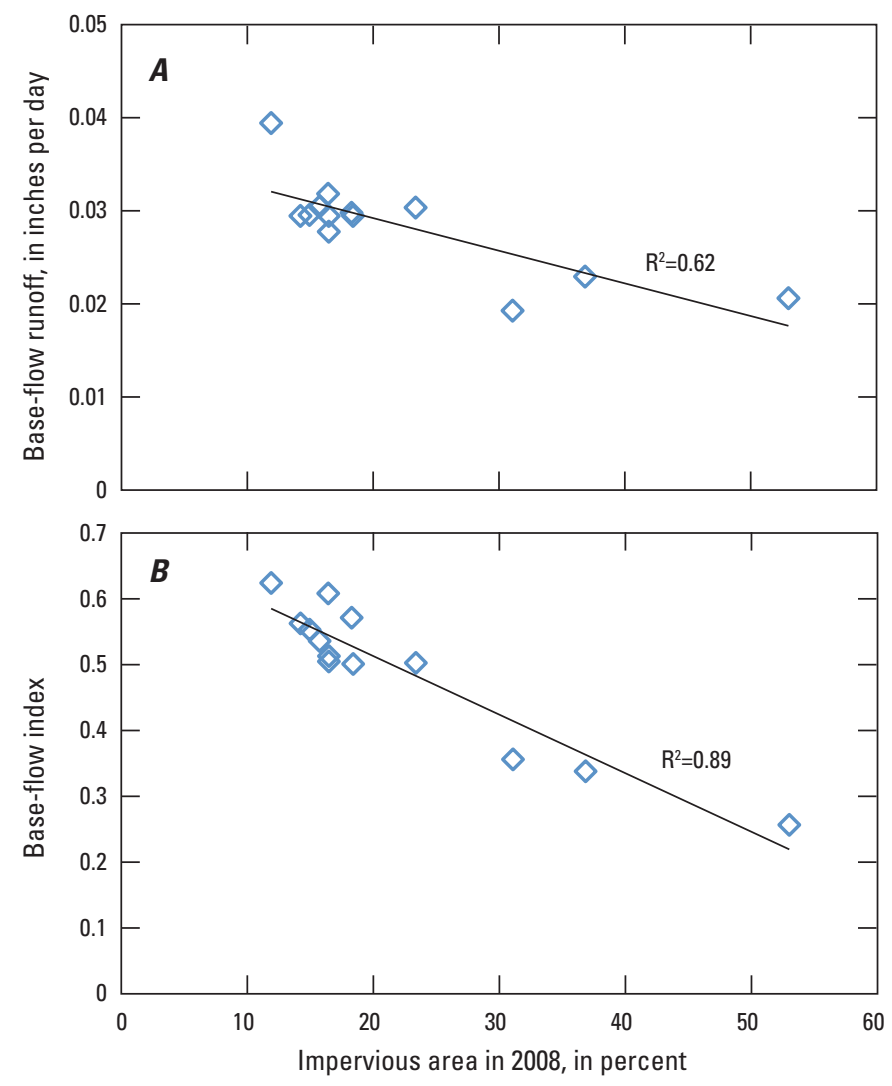

Figure 20. (A) Average base-flow runoff versus percentage of impervious area in 2008, and $(B)$ base-flow index (base-flow runoff divided by total runoff) versus percentage of impervious area in $\mathbf{2 0 0 8}$ for 13 watersheds in Gwinnett County, Georgia, for the period water years 2002-15. Sweetwater Creek watershed data are for water years 2011-15. 


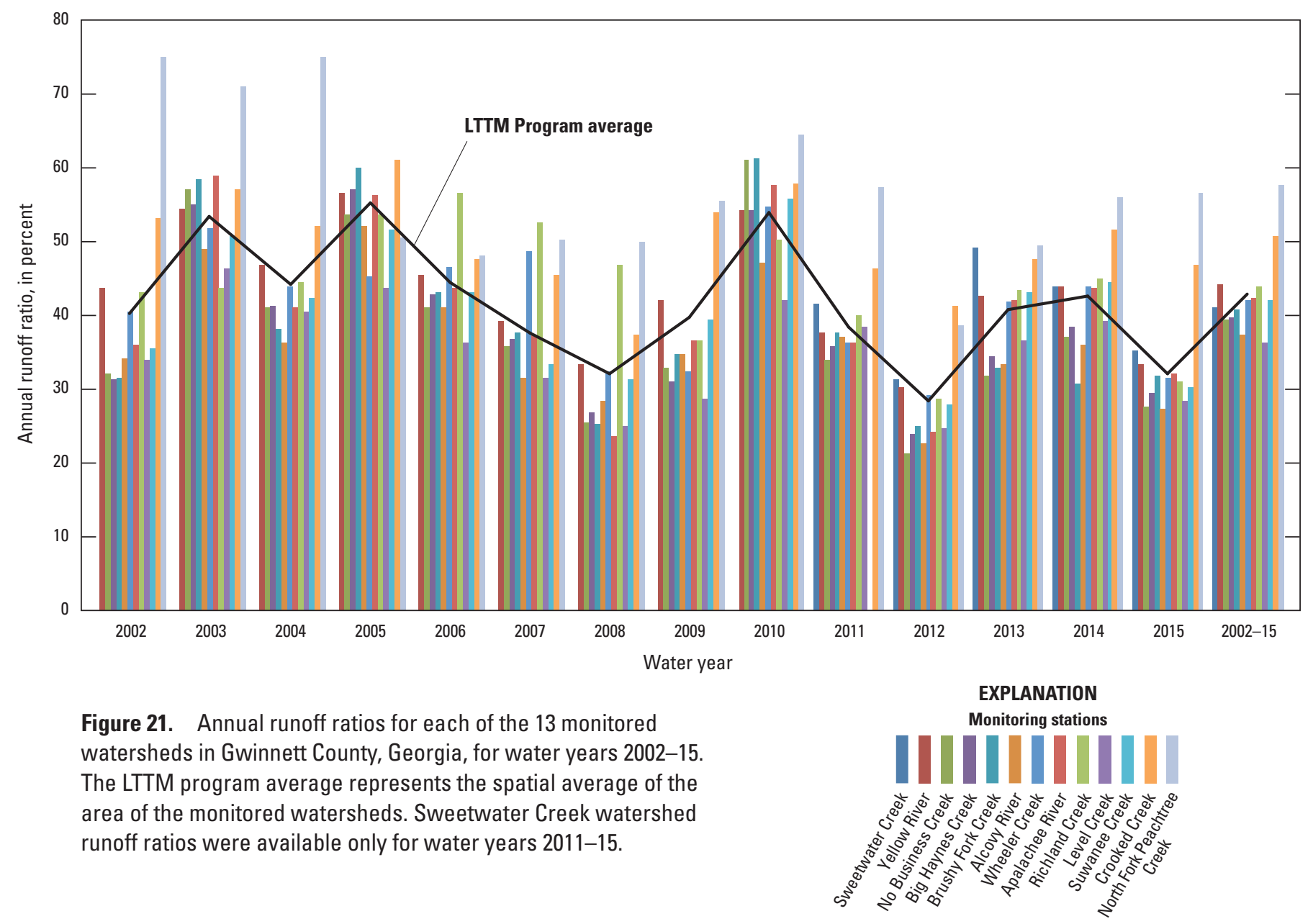

Runoff ratios for WYs 2002-15 were highest for the North Fork Peachtree Creek (57.5 percent), Crooked Creek (50.8 percent), Yellow River (44.2 percent), and Richland Creek (44.0 percent) watersheds and were lowest in the Level Creek (36.2 percent) and Alcovy River watersheds (37.5 percent; fig. 21). High runoff ratios in the North Fork Peachtree Creek, Crooked Creek, and Yellow River watersheds can likely be attributed to impervious areas (fig. 10; table 6), because these three watersheds had three of the four highest percentages of impervious areas of the 13 watersheds; $53.00,36.84$, and 23.37 percent of their watershed areas in 2008 (middle of study period), respectively. The high runoff ratio for the Richland Creek watershed is likely to be at least partially related to having the highest basin slope of any of the 13 watersheds (16.7 percent; fig. 5; table 5). Interestingly, annual runoff ratios for the Richland Creek watershed tended to be more above average with respect to the other watersheds in years when conditions became drier and less notably different in years when conditions became wetter. This pattern suggests that the Richland Creek watershed may have a larger dynamic groundwater storage component that provides more base flow during droughts compared to the other watersheds.

Watershed runoff ratios for the period WYs 2002-15 were positively related to the percentage of impervious areas within each watershed $\left(\mathrm{R}^{2}=0.73\right.$; fig. 22). The runoff ratios for the entire period were used to average the effects of climatic variations. The impervious areas were plotted for 2008, which represents the middle of the study period. This relation was evident despite implementation of BMPs to mitigate the effects of impervious areas on runoff within the watersheds. The relation would presumably be stronger, and runoff ratios would be higher, if it were not for the extensive implementation of BMPs. 


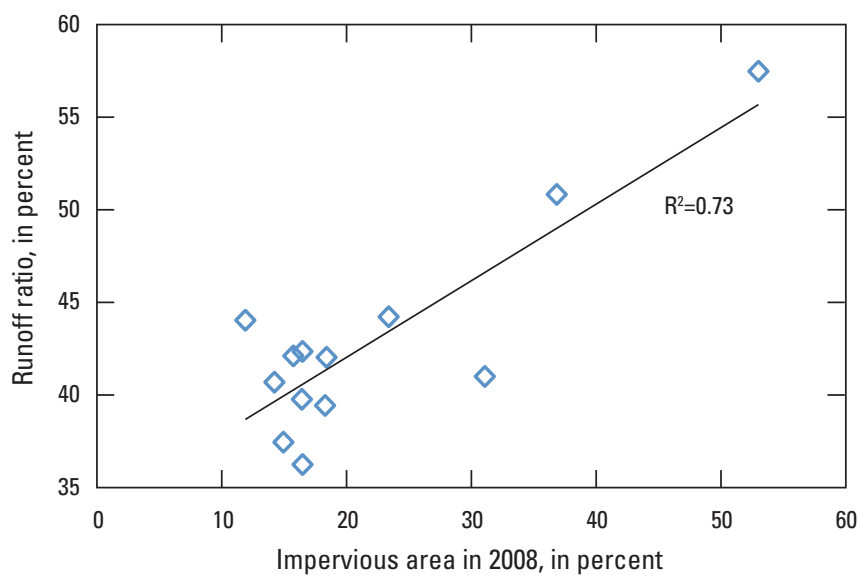

Figure 22. Runoff ratios for water years 2002-15 versus percentage of impervious areas in 2008 for each of the 13 monitored watersheds in Gwinnett County, Georgia. Sweetwater Creek watershed runoff ratio was calculated for water years 2011-15.

\section{Flood Frequency}

Reliable flood-frequency estimates are particularly important in densely populated urban areas. Urbanization changes a basin's response to precipitation. The most common effects are reduced infiltration and decreased lag time, which substantially increase peak flows (U.S. Department of Agriculture, 1986). Engineers and planners often need to consider the potential effects on peak flow of urban development scenarios in their design and planning efforts. Because urbanization can produce substantial changes in flood-frequency characteristics of streams, rural basin flood-frequency relations are not always applicable to urban streams. Historically, flood-frequency terminology was associated with a potentially misleading recurrence interval. To help alleviate any potential confusion with nomenclature and to further educate users, the recurrence interval terminology for flood events was adapted to further reflect the statistical meaning of the flood event, Annual Exceedance Probability (AEP; table 8).

The AEPs, 0.6667, 0.5, 0.2, 0.1, 0.04, 0.02, and 0.01, were computed using the long-term annual peak flow data from 13 streamgages in Gwinnett County, Ga., with 10 or more water years of annual peak flow record. Twelve of the 13 streamgages are part of the LTTM program. The other streamgage (USGS station 02208050) is a crest-stage gage, which records only peak flows. The annual peak flow data for these 13 streamgages ranged from 11 to 30 years. The annual peak flows for each station are fitted using a log-Pearson Type III distribution and Expected Moments Algorithm
Table 8. Historical terminology associated with flood-frequency estimates and corresponding annual exceedance probability and P-percent chance exceedance.

[From Feaster and others, 2014]

\begin{tabular}{ccc}
\hline $\begin{array}{c}\text { Recurrence } \\
\text { interval (yr) }\end{array}$ & $\begin{array}{c}\text { Annual exceedance } \\
\text { probability (AEP) }\end{array}$ & P-percent AEP \\
\hline 1.5 & 0.6667 & 67 \\
2 & 0.5 & 50 \\
5 & 0.2 & 20 \\
10 & 0.1 & 10 \\
25 & 0.04 & 4 \\
50 & 0.02 & 2 \\
100 & 0.01 & 1 \\
\hline
\end{tabular}

(EMA; Cohn and others, 1997) with a multiple Gubbs-Beck test (Cohn and others, 2013), which identifies potentially influential low flow outliers.

The estimated AEPs were computed using the USGS computer program PEAKFQ, which automates many of the procedures listed in Bulletin 17B, Guidelines for the Interagency Advisory Committee on Water Data (Veilleux and others, 2014). The PeakFQ results provided estimates of flood magnitudes, fitted frequency curves with 95 percent confidence intervals, and the mean square error (fig. 23) based on the annual peaks for each of the 13 streamgages. In comparing the results of the flood-frequency magnitudes in each watershed, having a longer length of record and more annual peaks improved the range of the 95 percent confidence interval. Table 9 provides the AEPs, corresponding estimates for discharge, and confidence intervals for each station. Model settings used to estimate AEP using PEAKFQ are listed in Aulenbach and Joiner (2017; table 2, flood frequency PEAKFQ input parameters).

Kendall's tau nonparametric test (Kendall, 1938) was used to determine statistical significance of monotonic trends in annual peak flows with time (Helsel and Hirsch, 1992). A trend was considered statistically significant if the Kendall's tau value significantly differed from zero using a probability value ( $p$-value) of $\leq 0.05$. None of the 13 streamgages showed a significant trend in the annual peak flow data. Increasing trends in annual peak flows would indiciate the likelihood of more frequent, higher magnitude flooding along with associated increases in bank erosion and sediment transport. 
Table 9. Annual exceedance probability (AEP) discharges estimated from 13 stations in the LTTM program study area, Gwinnett County, Georgia.

[AEP discharges estimated using Expected Moments Algorithm (EMA). $\mathrm{ft}^{3} / \mathrm{s}$, cubic foot per second; \%, percent]

\begin{tabular}{|c|c|c|c|c|}
\hline \multirow{2}{*}{$\begin{array}{l}\text { P-percent } \\
\text { AEP }\end{array}$} & \multirow{2}{*}{ AEP } & \multirow{2}{*}{$\begin{array}{l}\text { Discharge } \\
\left(\mathrm{ft}^{3} / \mathrm{s}\right)\end{array}$} & \multicolumn{2}{|c|}{ 95\% confidence intervals } \\
\hline & & & Lower & Upper \\
\hline \multicolumn{5}{|c|}{$\begin{array}{l}02207120 \text { Yellow River at GA 124, near Lithonia, GA } \\
\text { Period of record: } 2002-14 \\
\text { Number of years analyzed: } 13 \text { years }\end{array}$} \\
\hline 67 & 0.667 & 3,190 & 2,320 & 4,750 \\
\hline 50 & 0.5 & 4,040 & 2,780 & 6,250 \\
\hline 20 & 0.2 & 6,920 & 4,520 & 14,200 \\
\hline 10 & 0.1 & 9,580 & 6,160 & 28,100 \\
\hline 4 & 0.04 & 14,060 & 8,430 & 69,100 \\
\hline 2 & 0.02 & 18,400 & 10,200 & 124,000 \\
\hline 1 & 0.01 & 23,690 & 12,100 & 230,000 \\
\hline \multicolumn{5}{|c|}{$\begin{array}{c}02207185 \text { No Business Creek at Lee Road, below Snellville, GA } \\
\text { Period of record: } 2001-14 \\
\text { Number of years analyzed: } 14 \text { years }\end{array}$} \\
\hline 67 & 0.667 & 420 & 270 & 620 \\
\hline 50 & 0.5 & 560 & 380 & 820 \\
\hline 20 & 0.2 & 950 & 660 & 1,540 \\
\hline 10 & 0.1 & 1,250 & 860 & 2,460 \\
\hline 4 & 0.04 & 1,650 & 1,110 & 4,530 \\
\hline 2 & 0.02 & 1,960 & 1,270 & 6,870 \\
\hline 1 & 0.01 & 2,300 & 1,400 & 10,100 \\
\hline
\end{tabular}

\begin{tabular}{rlrrr}
02207385 Big Haynes Creek at Lenora Road, near Snellville, GA \\
Period of record: \\
Number of years analyzed: 14 years \\
\hline 67 & 0.6667 & 630 & 560 & 800 \\
50 & 0.5 & 700 & 890 & 920 \\
20 & 0.2 & 940 & 740 & 1,460 \\
10 & 0.1 & 1,160 & 900 & 2,180 \\
4 & 0.04 & 1,520 & 1,100 & 4,020 \\
2 & 0.02 & 1,850 & 1,250 & 6,270 \\
1 & 0.01 & 2,260 & 1,400 & 10,100 \\
\hline
\end{tabular}

02207400 Brushy Fork Creek at Beaver Road, near Loganville, GA Period of record: 1997-2014

Number of years analyzed: 17 years

\begin{tabular}{rlrrr}
67 & 0.6667 & 270 & 210 & 360 \\
50 & 0.5 & 330 & 260 & 440 \\
20 & 0.2 & 510 & 390 & 740 \\
10 & 0.1 & 640 & 480 & 1,110 \\
4 & 0.04 & 830 & 600 & 2,200 \\
2 & 0.02 & 990 & 690 & 3,200 \\
1 & 0.01 & 1,160 & 770 & 4,670 \\
\hline
\end{tabular}

\begin{tabular}{|c|c|c|c|c|}
\hline \multirow{2}{*}{$\begin{array}{c}\text { P-percent } \\
\text { AEP }\end{array}$} & \multirow{2}{*}{ AEP } & \multirow{2}{*}{$\begin{array}{c}\text { Discharge } \\
\left(\mathrm{ft}^{3} / \mathrm{s}\right)\end{array}$} & \multicolumn{2}{|c|}{ 95\% confidence intervals } \\
\hline & & & Lower & Upper \\
\hline \multicolumn{5}{|c|}{$\begin{array}{l}02208050 \text { Alcovy River near Lawrenceville, GA } \\
\text { Period of record: } 1965-2014 \\
\text { Number of years analyzed: } 29 \text { years }\end{array}$} \\
\hline 67 & 0.6667 & 560 & 440 & 700 \\
\hline 50 & 0.5 & 710 & 570 & 890 \\
\hline 20 & 0.2 & 1,140 & 910 & 1,510 \\
\hline 10 & 0.1 & 1,480 & 1,150 & 2,110 \\
\hline 4 & 0.04 & 1,950 & 1,450 & 3,240 \\
\hline 2 & 0.02 & 2,350 & 1,670 & 4,520 \\
\hline 1 & 0.01 & 2,780 & 1,890 & 6,320 \\
\hline \multicolumn{5}{|c|}{$\begin{array}{l}02208150 \text { Alcovy River at New Hope Road, near Grayson, GA } \\
\text { Period of record: } 2001-14 \\
\text { Number of years analyzed: } 14 \text { years }\end{array}$} \\
\hline 67 & 0.6667 & 1,500 & 980 & 2,350 \\
\hline 50 & 0.5 & 2,040 & 1,300 & 3,320 \\
\hline 20 & 0.2 & 3,960 & 2,450 & 8,520 \\
\hline 10 & 0.1 & 5,780 & 3,500 & 17,900 \\
\hline 4 & 0.04 & 8,910 & 5,020 & 52,100 \\
\hline 2 & 0.02 & 12,000 & 6,280 & 97,200 \\
\hline 1 & 0.01 & 15,700 & 7,650 & 183,000 \\
\hline
\end{tabular}

02217274 Wheeler Creek at Bill Cheek Road, near Auburn, Ga Period of record: 1997-2014

Number of years analyzed: 18 years

\begin{tabular}{rlrrr}
\multicolumn{5}{c}{ Number of years analyzed: 18 years } \\
\hline 67 & 0.6667 & 140 & 80 & 240 \\
50 & 0.5 & 220 & 130 & 380 \\
20 & 0.2 & 520 & 310 & 1,050 \\
10 & 0.1 & 810 & 470 & 2,160 \\
4 & 0.04 & 1,310 & 720 & 5,920 \\
2 & 0.02 & 1,790 & 920 & 12,900 \\
1 & 0.01 & 2,370 & 1,120 & 23,800 \\
\hline
\end{tabular}

02218565 Apalachee River at Fence Road, near Dacula, GA Period of record: 1994-2014

Number of years analyzed: 21 years

\begin{tabular}{rlrrr}
\hline 67 & 0.6667 & 350 & 230 & 500 \\
50 & 0.5 & 480 & 340 & 680 \\
20 & 0.2 & 860 & 620 & 1,270 \\
10 & 0.1 & 1,150 & 820 & 1,960 \\
4 & 0.04 & 1,530 & 1,070 & 3,320 \\
2 & 0.02 & 1,830 & 1,220 & 4,660 \\
1 & 0.01 & 2,040 & 1,340 & 6,390 \\
\hline
\end{tabular}


Table 9. Annual exceedance probability (AEP) discharges estimated from 13 stations in the LTTM program study area, Gwinnett County, Georgia.-Continued

[AEP discharges estimated using Expected Moments Algorithm (EMA). $\mathrm{ft}^{3} / \mathrm{s}$, cubic foot per second; \%, percent]

\begin{tabular}{|c|c|c|c|c|}
\hline \multirow{2}{*}{$\begin{array}{l}\text { P-percent } \\
\text { AEP }\end{array}$} & \multirow{2}{*}{ AEP } & \multirow{2}{*}{$\begin{array}{l}\text { Discharge } \\
\left(\mathrm{ft}^{3} / \mathrm{s}\right)\end{array}$} & \multicolumn{2}{|c|}{$95 \%$ confidence intervals } \\
\hline & & & Lower & Upper \\
\hline \multicolumn{5}{|c|}{$\begin{array}{l}02334480 \text { Richland Creek at Suwanee Dam Road, near Buford, GA } \\
\text { Period of record: } 1995-2014 \\
\text { Number of years analyzed: } 20 \text { years }\end{array}$} \\
\hline 67 & 0.667 & 770 & 500 & 1,120 \\
\hline 50 & 0.5 & 1,070 & 730 & 1,540 \\
\hline 20 & 0.2 & 1,950 & 1,370 & 2,950 \\
\hline 10 & 0.1 & 2,620 & 1,830 & 4,650 \\
\hline 4 & 0.04 & 3,540 & 2,430 & 8,520 \\
\hline 2 & 0.02 & 4,260 & 2,810 & 13,000 \\
\hline 1 & 0.01 & 5,020 & 3,130 & 19,400 \\
\hline \multicolumn{5}{|c|}{$\begin{array}{l}02334578 \text { Level Creek at Suwanee Dam Road, near Suwanee, GA } \\
\text { Period of record: } 2003-14 \\
\text { Number of years analyzed: } 12 \text { years }\end{array}$} \\
\hline 67 & 0.6667 & 510 & 290 & 880 \\
\hline 50 & 0.5 & 730 & 420 & 1,310 \\
\hline 20 & 0.2 & 1,530 & 870 & 3,620 \\
\hline 10 & 0.1 & 2,290 & 1,280 & 7,810 \\
\hline 4 & 0.04 & 3,580 & 1,880 & 24,700 \\
\hline 2 & 0.02 & 4,820 & 2,370 & 45,300 \\
\hline 1 & 0.01 & 6,330 & 2,890 & 83,000 \\
\hline \multicolumn{5}{|c|}{$\begin{array}{l}02334885 \text { Suwanee Creek at Suwanee, GA } \\
\text { Period of record: } 1985-2014 \\
\text { Number of years analyzed: } 30 \text { years }\end{array}$} \\
\hline 67 & 0.667 & 1,350 & 1,010 & 1,760 \\
\hline 50 & 0.5 & 1,810 & 1,380 & 2,360 \\
\hline 20 & 0.2 & 3,150 & 2,420 & 4,350 \\
\hline 10 & 0.1 & 4,200 & 3,180 & 6,470 \\
\hline 4 & 0.04 & 5,680 & 4,150 & 10,800 \\
\hline 2 & 0.02 & 6,890 & 4,840 & 15,600 \\
\hline 1 & 0.01 & 8,090 & 5,460 & 22,100 \\
\hline
\end{tabular}

\begin{tabular}{|c|c|c|c|c|}
\hline \multirow{2}{*}{$\begin{array}{c}\text { P-percent } \\
\text { AEP }\end{array}$} & \multirow{2}{*}{ AEP } & \multirow{2}{*}{$\begin{array}{c}\text { Discharge } \\
\left(\mathrm{ft}^{3} / \mathrm{s}\right)\end{array}$} & \multicolumn{2}{|c|}{$95 \%$ confidence intervals } \\
\hline & & & Lower & Upper \\
\hline \multicolumn{5}{|c|}{$\begin{array}{c}02335350 \text { Crooked Creek near Norcross, GA } \\
\text { Period of record: } 2001-14 \\
\text { Number of years analyzed: } 14 \text { years }\end{array}$} \\
\hline 67 & 0.6667 & 960 & 810 & 1,230 \\
\hline 50 & 0.5 & 1,090 & 880 & 1,460 \\
\hline 20 & 0.2 & 1,540 & 1,180 & 2,490 \\
\hline 10 & 0.1 & 1,910 & 1,440 & 3,890 \\
\hline 4 & 0.04 & 2,500 & 1,770 & 7,210 \\
\hline 2 & 0.02 & 3,040 & 2,010 & 11,200 \\
\hline 1 & 0.01 & 3,660 & 2,250 & 18,000 \\
\hline
\end{tabular}

02336030 N.F. Peachtree Creek at Graves Road, near Doraville, GA Period of record: 2004-14 Number of years analyzed: 11 years

\begin{tabular}{rlrrr}
\hline 67 & 0.6667 & 850 & 560 & 1,203 \\
50 & 0.5 & 1,075 & 730 & 1,590 \\
20 & 0.2 & 1,730 & 1,190 & 3,000 \\
10 & 0.1 & 2,220 & 1,520 & 4,850 \\
4 & 0.04 & 2,920 & 1,930 & 9,560 \\
2 & 0.02 & 3,480 & 2,220 & 14,100 \\
1 & 0.01 & 4,090 & 2,490 & 20,000 \\
\hline
\end{tabular}




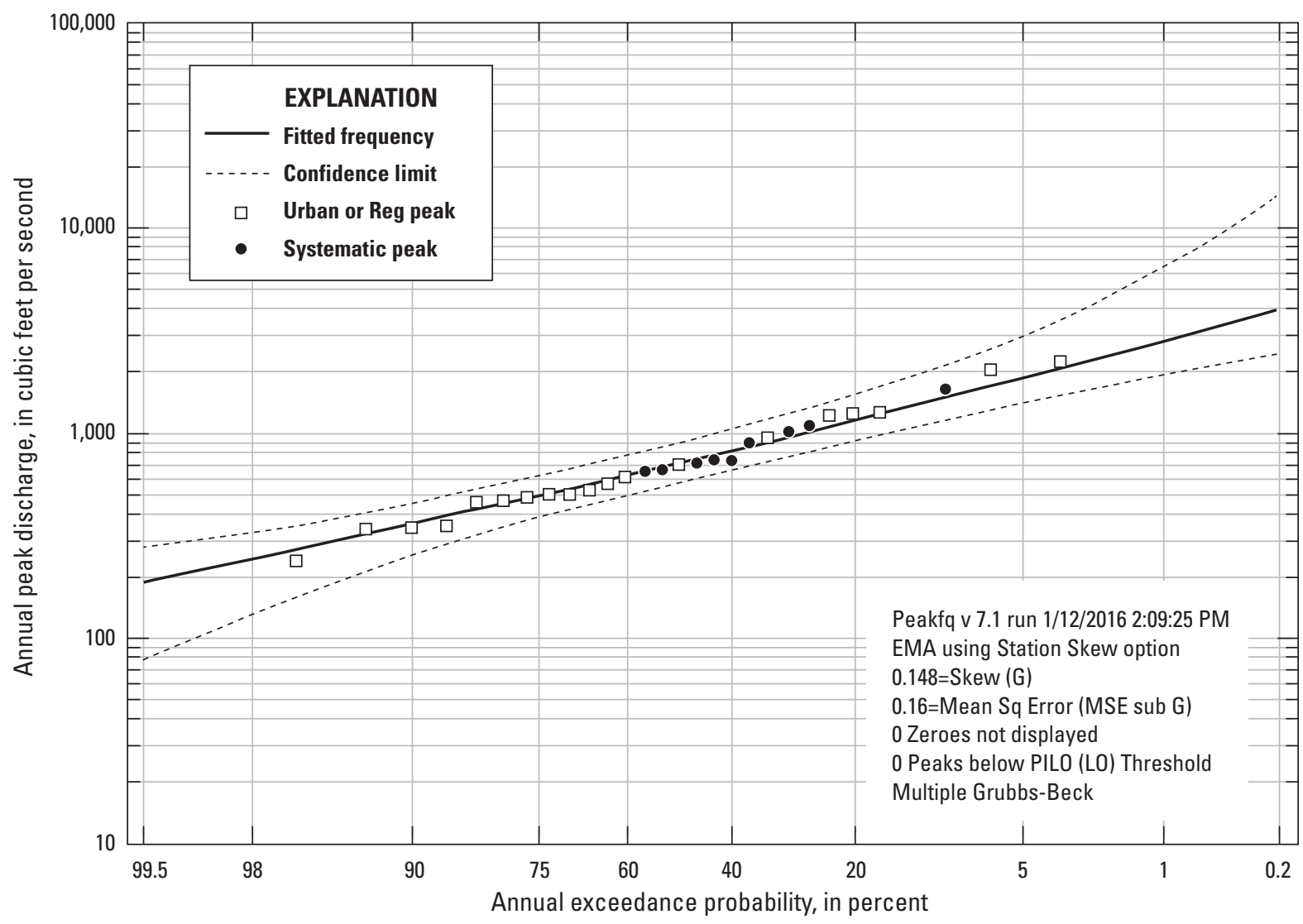

Figure 23. Example of PeakFO probability graph of annual peaks, fitted frequency curve, and confidence limits for USGS station 02208050, Alcovy River near Lawrenceville, Georgia. [Reg, regulated] 


\section{Surface-Water Quality}

Patterns in continuous water-quality monitoring data for specific conductance (SC) and turbidity and their relation to other water-quality constituents were assessed. Statistical summaries of 13 measured or calculated constituents are provided for each of the 13 watersheds. Comparisons are made between base-flow and storm-composited concentrations.

\section{Continuous Water-Quality Monitoring}

Water-quality monitors were installed at all gages to continuously measure water temperature, SC, and turbidity. These continuous water-quality data are used to assess relations with constituents analyzed from base-flow and stormflow samples. For example, SC is related to the type and concentration of dissolved constituents in water and, thus, is a useful surrogate for total dissolved solids or other dissolved constituents. Specific conductance typically varies inversely with discharge - a process referred to as dilution - at the 13 LTTM program stations (fig. 24). Dilution is a commonly observed relation that occurs for many dissolved constituents when, during stormflow, there is a larger proportion of dilute water from precipitation runoff and shallow flow paths, compared to base-flow concentrations, contributing to streamflow. This is not always the case, because some dissolved constituents are mobilized and transported during higher discharges.

Turbidity is an optical water-quality property related to the amount of light scattered or absorbed by suspended and dissolved matter and often is a good surrogate for suspended sediment. Turbidity can also be a surrogate for a wide range of other constituents, because certain pollutants, such as heavy metals, pesticides, and fecal coliform, adhere to suspendedsediment particles. The U.S. Environmental Protection Agency (2010) lists sediment and other solid-phase constituents as some of the most common sources of impairment in Georgia streams. Strong relations were observed during this study between turbidity and many of the water-quality constituents measured during base-flow and stormflow sampling. For example, relations for TSS, SSC, $\mathrm{Pb}$, and $\mathrm{Zn}$ are shown for the Sweetwater Creek watershed (fig. 25). Because turbidity is continuously monitored and is highly related to many of the water-quality constituents analyzed as part of this program, turbidity was included as a possible explanatory variable for the concentration models used to estimate loads.

\section{Base-Flow and Stormflow Water Quality}

Statistical summaries of the water-quality sample concentrations for 13 field and laboratory constituents (table 2) are provided in Aulenbach and Joiner (2017; table 4, water-quality constituent statistics). Graphical summaries for the 13 constituents in table 2 for both base-flow and stormflow conditions are shown in figure 26.

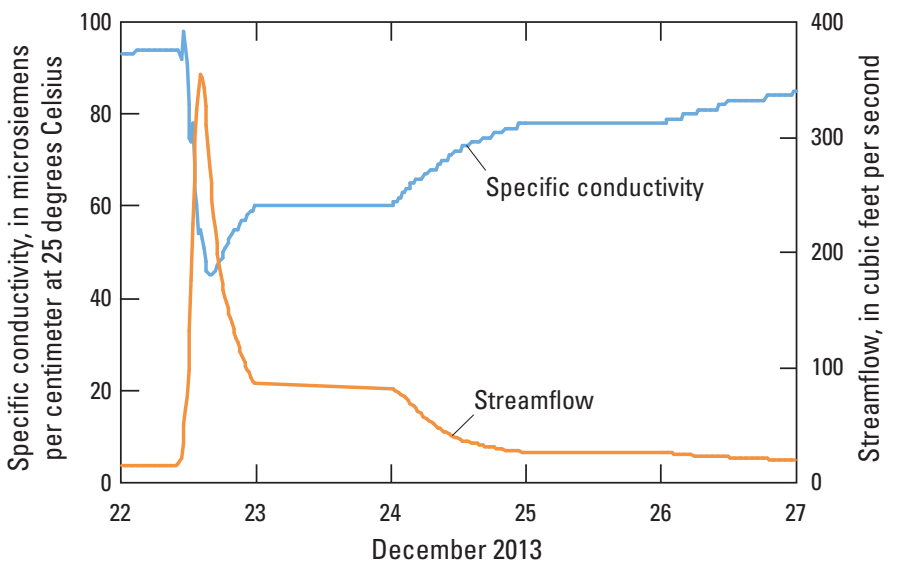

Figure 24. Stormflow response of specific conductance to streamflow for USGS station 02205865, Sweetwater Creek at Club Drive near Lilburn, Georgia, December 22-27, 2013.

Specific conductance typically varied between about 50 and 200 microsiemens per centimeter $(\mu \mathrm{S} / \mathrm{cm})$ at 25 degrees Celsius (fig. 26A). The term "typical" used in this discussion refers to the approximate range of values observed in concentrations within the box-and-whisker plots and not the range of values of the outside and detached concentrations. Specific conductance was significantly lower during stormflow than base flow at 12 of the 13 watersheds, indicating that dissolved constituents generally were diluted during stormflow conditions. Specific conductance typically was highest for Yellow River and Suwannee Creek watersheds. Turbidity typically varied between about 2 and 20 FNU for base-flow samples and between about 20 and 2,000 FNU for stormflow samples (fig. 26B). Turbidity values were significantly higher in stormflow samples, with stormflow turbidities generally 1 to 2 orders of magnitude higher than base-flow turbidities, reflecting the transport of sediment during these conditions.

Nitrogen concentrations typically varied between about 0.2 and 5 milligrams per liter as nitrogen $(\mathrm{mg} / \mathrm{L}$ as $\mathrm{N})$ for total nitrogen (TN; fig. $26 C$ ), between about $<0.25$ and $5 \mathrm{mg} / \mathrm{L}$ as $\mathrm{N}$ for total ammonia plus organic nitrogen (TKN; fig. 26D), and between about $<0.27$ and $5 \mathrm{mg} / \mathrm{L}$ as $\mathrm{N}$ for total nitrate plus nitrite $\left(\mathrm{NO}_{3}+\mathrm{NO}_{2} ;\right.$ fig. 26E). Differences between base-flow and stormflow $\mathrm{NO}_{3}+\mathrm{NO}_{2}$ concentrations varied across the watersheds, with significantly lower concentrations observed during stormflow at Yellow River, No Business Creek, Big Haynes Creek, Alcovy River, Wheeler Creek, Richland Creek, and Suwanee Creek watersheds, significantly higher concentrations observed during stormflow at Apalachee Creek and Level Creek watersheds, and similar ranges in concentrations observed at the other four watersheds. Total ammonia plus organic nitrogen concentrations in stormflow samples were significantly higher than concentrations in base-flow samples at all the watersheds, and TN concentrations in stormflow samples were significantly higher than concentrations in base-flow samples at all but two watersheds. Stormflow sample concentrations typically were about twice as high 

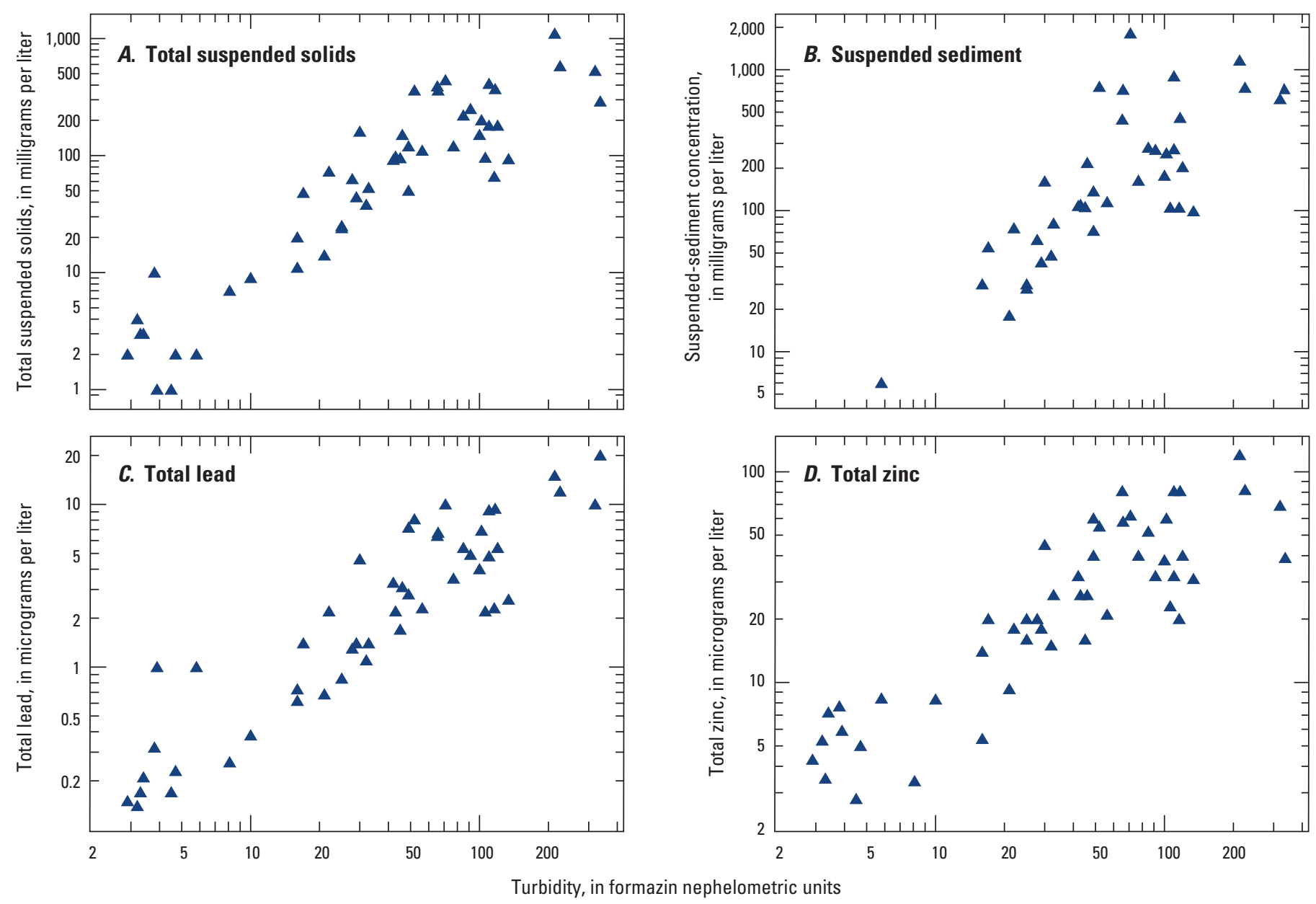

Figure 25. (A) Total suspended solids, $(B)$ suspended sediment, $(C)$ total lead, and $(D)$ total zinc sample concentrations versus turbidity for USGS station 02205865, Sweetwater Creek at Club Drive near Lilburn, Georgia.

as base-flow sample concentrations. Both Yellow River and No Business Creek watersheds have similar TN concentrations for base-flow and stormflow samples, and the increase in TN concentrations during stormflow observed for Suwannee Creek watershed was less than observed at the other watersheds that had significant increases.

Total phosphorus concentrations typically varied between about $<0.005$ and $1 \mathrm{mg} / \mathrm{L}$ as phosphorus (P) (fig. 26F). Stormflow TP concentrations were significantly higher than base-flow concentrations by about an order of magnitude, indicating that the majority of transport occurred during storm events. Total phosphorus concentrations were often $>0.1 \mathrm{mg} / \mathrm{L}$ in stormflow samples, which is the threshold at which TP concentrations are considered to be able to support nuisance levels of algal production in flowing waters (U.S. Environmental Protection Agency, 2000a). Dissolved phosphorus concentrations typically were less than $0.1 \mathrm{mg} / \mathrm{L}$ as $\mathrm{P}$ and exhibited no particular pattern of differences between base-flow and stormflow conditions, though a few differences were significant (fig. 26G). A comparison of mean DP and TP concentrations indicates that about two-thirds to three-quarters of the phosphorus exists in solid form; therefore, it is not unexpected that TP concentrations would be higher when discharge and suspended-sediment concentrations are higher. Richland Creek watershed had the highest mean stormflow TP concentration, $0.235 \mathrm{mg} / \mathrm{L}$ as $\mathrm{P}$, which may be the result of high runoffs (fig. 15) and runoff ratios (fig. 21) associated with the watershed having the highest basin slope of the 13 watersheds (fig. 5; table 5). Sweetwater Creek had the lowest mean stormflow TP concentration of $0.059 \mathrm{mg} / \mathrm{L}$ as $\mathrm{P}$.

Total organic carbon (TOC) typically varied between about 0.5 and $4 \mathrm{mg} / \mathrm{L}$ as carbon in base-flow samples and between about 2 and $20 \mathrm{mg} / \mathrm{L}$ as carbon in stormflow samples (fig. 26H). Stormflow TOC concentrations were significantly higher than during base flow by about half an order of magnitude, but comparisons varied by watershed. Stormflow TOC concentrations were fairly similar among all 13 watersheds, whereas individual watersheds had more distinct base-flow concentrations.

Total suspended solids (TSS) and suspended-sediment concentrations (SSC) typically varied between about $<1$ and 5,000 mg/L (figs. 26I and 26J). Total suspended solids and SSC concentrations are similar, with the same pattern 


\section{Interpreting box-and-whisker plots}

The box-and-whisker plots in figure 26 illustrate the range and distribution of sample concentrations for each watershed and sampling flow condition (Helsel and Hirsch, 1992). The top and bottom of the "box" (rectangle) represents the 75th and 25th quartiles of sample concentrations, respectively, and the line within the box represents the 50th percentile (median concentration). The "whiskers" (lines extending above and below the box) represent the range of sample concentrations within one step above or below the interquartile range represented by the box and are referred to as "adjacent" values. A step is defined as 1.5 times the interquartile range (the height of the box). Concentrations between one and two steps from the box in either direction are referred to as "outside" values and are expected to occur fewer than one in 100 times for data that follow a normal distribution. Concentrations greater than two steps from the box are referred to as either "detached" or "far-out" values. Outside values are plotted as X symbols, and detached values are plotted as circles. Concentrations were plotted on a log scale because they exhibited a normal distribution in log space. The magnitude of a censored value (its laboratory reporting limit [LRL]; table 2) or an estimated value (a concentration above its long-term method detection level [LT-MDL] but below its LRL) was used to plot its concentration in the box-and-whisker plots. All sample concentrations were plotted, including values that were excluded as outliers for the development of the load estimation models. Significant differences between individual watershed base-flow and stormflow sample concentration distributions were determined using the Mann-Whitney $\mathrm{U}$ test (also called the Wilcox rank-sum test) with a significance level of $p$-value $\leq 0.05$.

of relative difference between watersheds observed for both constituents that is especially apparent in the stormflow concentrations. Suspended-sediment concentrations typically were slightly higher than TSS concentrations during both base-flow and stormflow conditions. Stormflow TSS and SSC concentrations are significantly higher than base-flow concentrations by about two orders of magnitude, emphasizing the relation between discharge and sediment mobilization and transport. Richland Creek watershed, which had the highest basin slope of any of the 13 watersheds (fig. 5; table 5), had the highest median TSS concentration, $194 \mathrm{mg} / \mathrm{L}$ (Aulenbach and Joiner, 2017; table 4, water-quality constituent statistics). The two orders of magnitude increase of TSS concentrations from base flow to stormflow compared to the one order of magnitude increase for TP concentrations suggests that the suspended sediment transported during storm events has a disproportionately smaller ratio of TP compared to base-flow conditions. Total suspended solids concentrations are about three orders of magnitude greater than TP in storm event samples, indicating that TP is only a small portion of TSS.

In a previous analysis of the Gwinnett County LTTM program watersheds for the period 1998-2003, Landers and others (2007) found concentrations (and loads) of TSS typically were less than concentrations (and loads) of SSC for six watersheds. The comparison of TSS to SSC was reevaluated using data from 12 watersheds for the period 2005-09 (Joiner and others, 2014), and measured TSS concentrations continued to be less than SSC concentrations. This difference is more pronounced for samples in which the sediment contains more than 25 percent sand (the coarser portion of the sediment).
Total lead $(\mathrm{Pb})$ concentrations typically varied between $<1$ and 10 micrograms per liter $(\mu \mathrm{g} / \mathrm{L})$ in base-flow samples and between $<1$ and $120 \mu \mathrm{g} / \mathrm{L}$ in stormflow samples (fig. 26K). Total lead concentrations sometimes exceeded the national recommended freshwater aquatic life critera for particulate lead of $65 \mu \mathrm{g} / \mathrm{L}$ for acute conditions and $2.5 \mu \mathrm{g} / \mathrm{L}$ for chronic conditions (U.S. Environmental Protection Agency, 2017). Base-flow $\mathrm{Pb}$ concentrations had a large range at 6 of the 13 watersheds, with about one-and-a-half orders of magnitude range between the 25th and 75th percentiles of concentrations. Stormflow $\mathrm{Pb}$ concentrations were about half an order of magnitude higher than base-flow concentrations.

Total zinc $(\mathrm{Zn})$ concentrations typically varied between $<2$ and $850 \mu \mathrm{g} / \mathrm{L}$ (fig. 26L). Total zinc concentrations sometimes exceeded the national recommended freshwater aquatic life critera for particulate zinc of $120 \mu \mathrm{g} / \mathrm{L}$ for both acute and chronic conditions (U.S. Environmental Protection Agency, 2017). Stormflow $\mathrm{Zn}$ concentrations were about one order of magnitude higher than base-flow concentrations, but comparisons varied by watershed. Apalachee River, Richland Creek, Suwanee Creek, and Crooked Creek watersheds exhibited the largest order of magnitude increases between base-flow and stormflow Zn concentrations. Alcovy River, Apalachee River, Richland Creek, Suwanee Creek, Crooked Creek, and North Fork Peachtree Creek watersheds had the highest stormflow $\mathrm{Zn}$ and $\mathrm{Pb}$ concentrations. Some of these high concentrations may be related to the high basin slope at Richland Creek (fig. 5; table 5) and the high percentage of impervious areas for Crooked Creek and North Fork Peachtree Creek (fig. 10; table 6). 

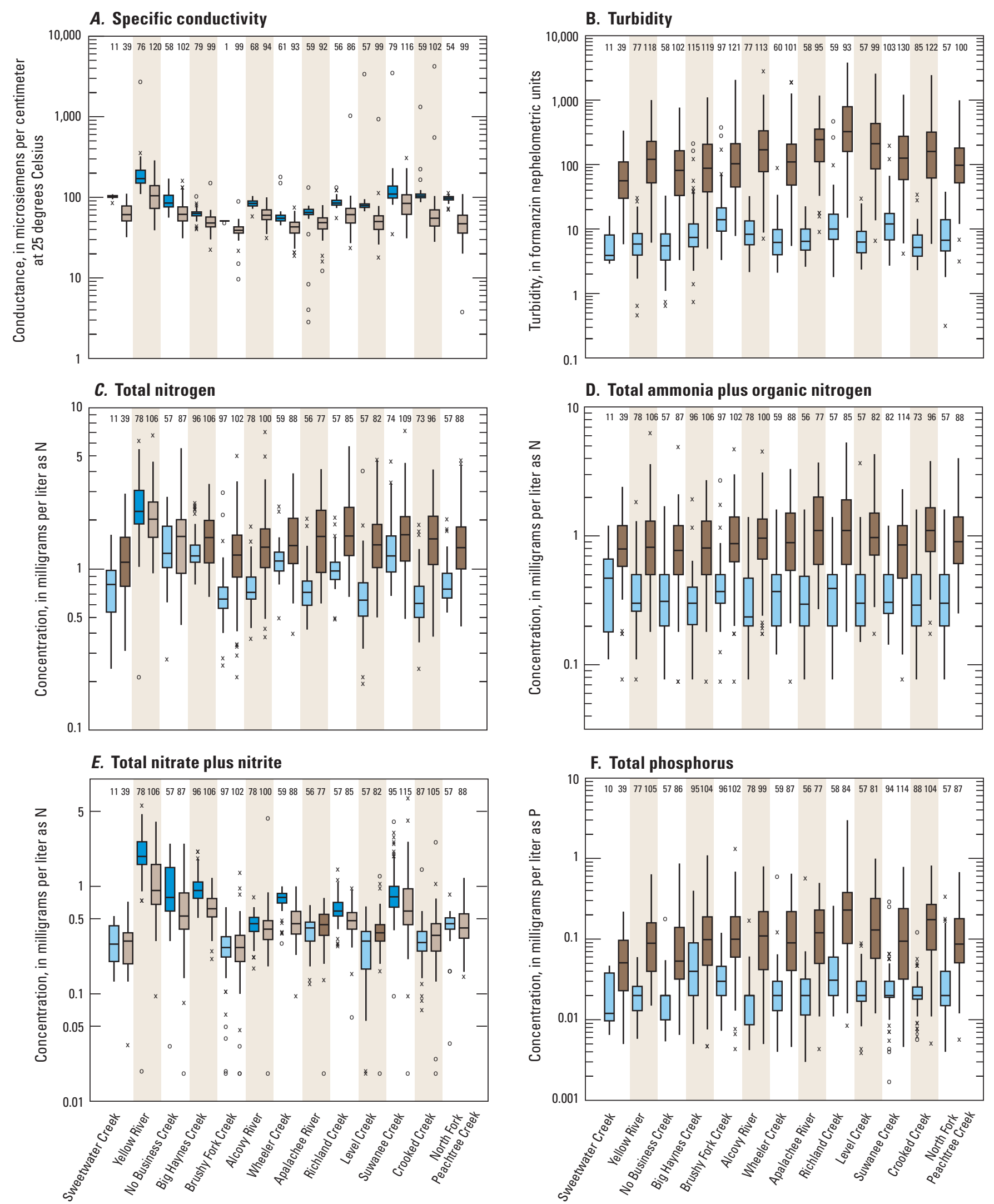

Monitored watersheds, Gwinnett County

Figure 26. Base-flow and stormflow sample concentrations for $(A)$ specific conductance, $(B)$ turbidity, $(C)$ total nitrogen, $(D)$ total ammonia plus organic nitrogen, $(E)$ total nitrate plus nitrite, and $(F)$ total phosphorus at 13 monitored watersheds in Gwinnett County, Georgia. Significant difference between base-flow and stormflow sample concentration distributions determined from Mann-Whitney $U$ test with a $p$-value of $\leq 0.05$. Data-collection period ranges from 2001 to 2015. 


\section{G. Dissolved phosphorus}

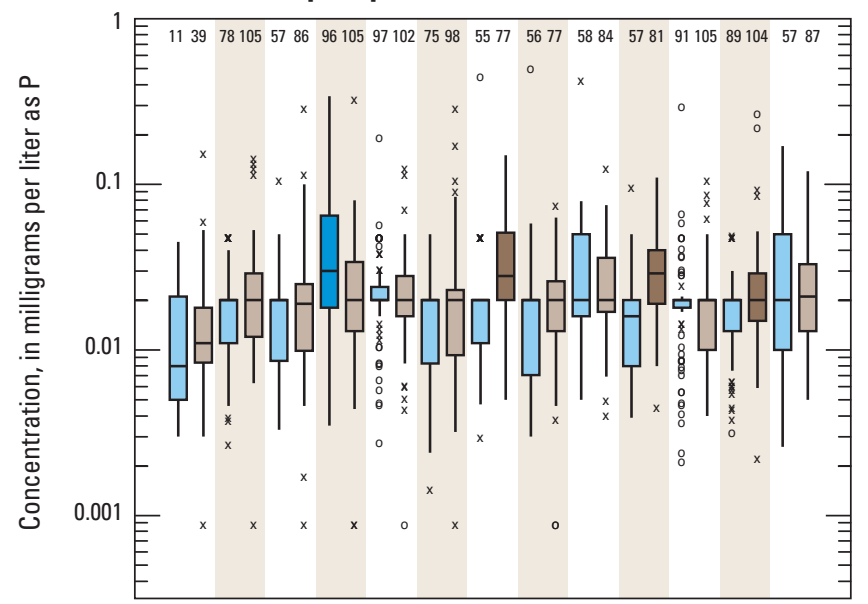

I. Total suspended solids

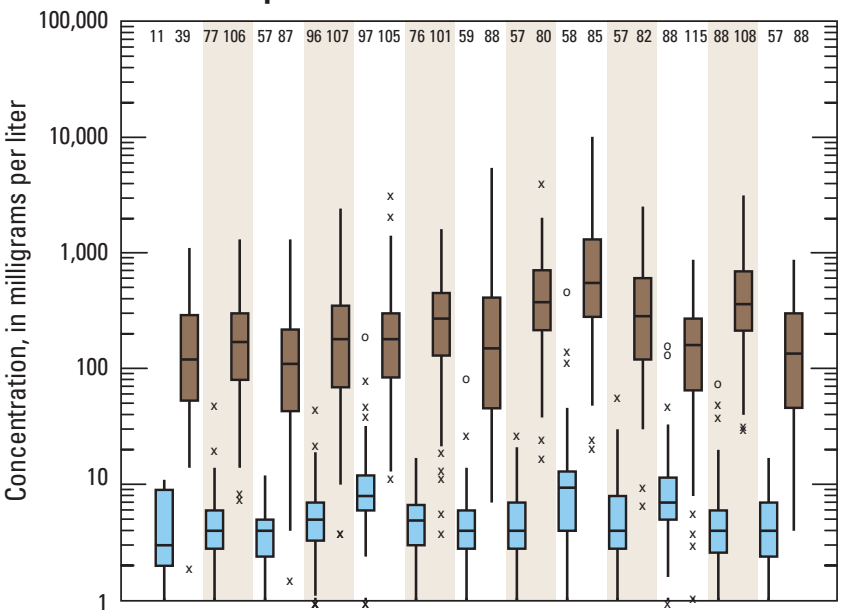

\section{K. Total lead}

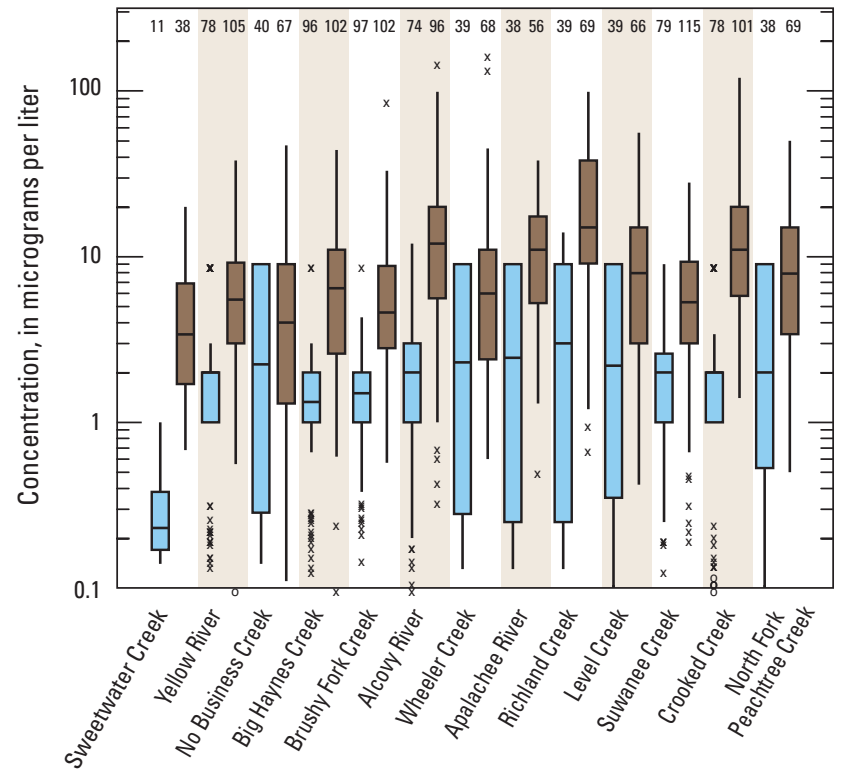

\section{H. Total organic carbon}

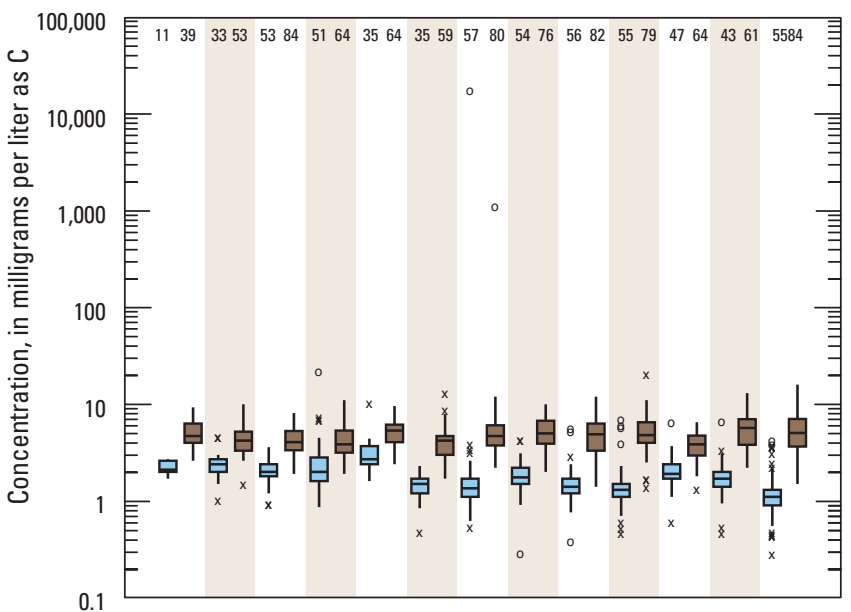

\section{J. Suspended sediment}
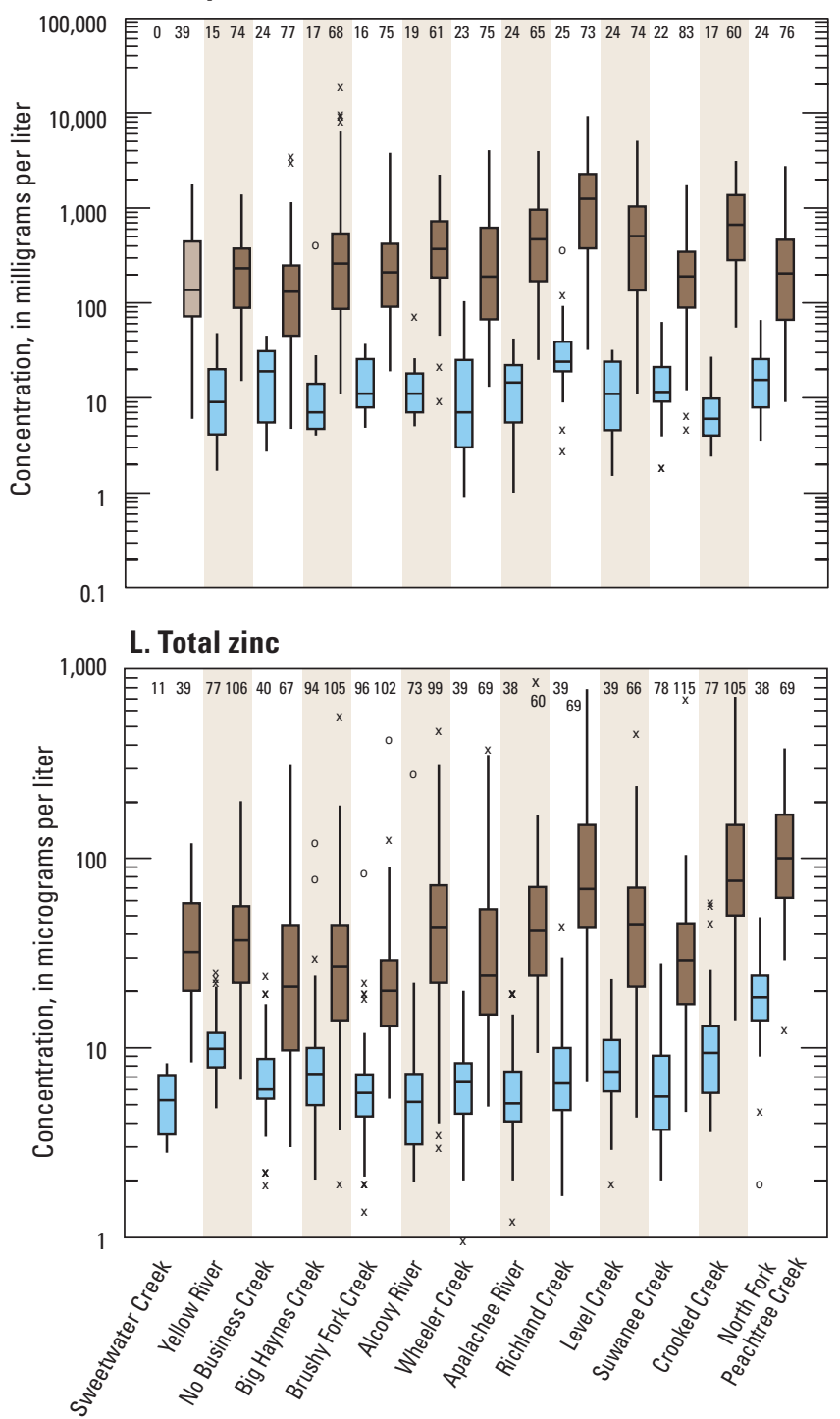

Monitored watersheds, Gwinnett County

Figure 26. Base-flow and stormflow sample concentrations for $(G)$ dissolved phosphorus, $(H)$ total organic carbon, $(/)$ total suspended solids, $(J)$ suspended sediment, $(K)$ total lead, and $(L)$ total zinc at 13 monitored watersheds in Gwinnett County. Significant difference between base-flow and stormflow sample concentration distributions determined from Mann-Whitney $U$ test with a $p$-value of $\leq 0.05$. Data-collection period ranges from 2001 to 2015 . - Continued 


\section{Total dissolved solids}

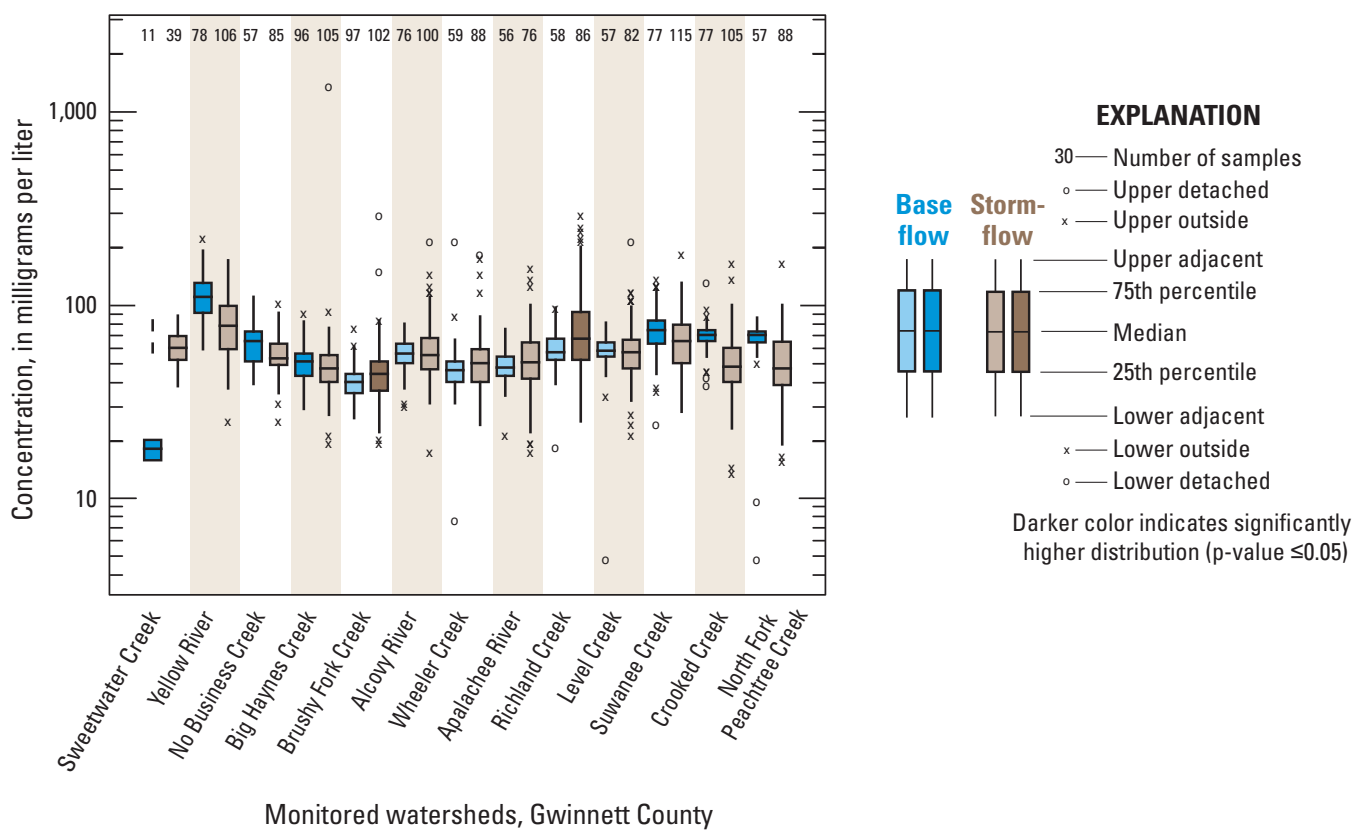

Figure 26. Base-flow and stormflow sample concentrations for $(M)$ total dissolved solids at 13 monitored watersheds in Gwinnett County. Significant difference between base-flow and stormflow sample concentration distributions determined from Mann-Whitney $\mathrm{U}$ test with a $p$-value of $\leq 0.05$. Data-collection period ranges from 2001 to 2015.-Continued

Total dissolved solids (TDS) concentrations represent the amount of inorganic and organic constituents that are dissolved in water; concentrations in the LTTM program watersheds typically varied between 20 and $200 \mathrm{mg} / \mathrm{L}$

(fig. 26M). The U.S. Environmental Protection Agency has established TDS as a secondary drinking water standard with a maximum contaminant level of $500 \mathrm{mg} / \mathrm{L}$, because high concentrations of TDS can be an indicator of elevated levels of other pollutants (U.S. Environmental Protection Agency, 2011). Seven of the watersheds-Sweetwater Creek, Yellow River, No Business Creek, Big Haynes Creek, Suwanee Creek, Crooked Creek, and North Fork Peachtree Creek-exhibited dilution in TDS concentrations during storm events. Four of these watersheds-Yellow River, Suwanee Creek, Crooked
Creek, and North Fork Peachtree Creek-had the four highest percentages of impervious area (fig. 10; table 6). The Yellow River watershed had the highest median TDS concentrations of $91 \mathrm{mg} / \mathrm{L}$ (Aulenbach and Joiner, 2017; table 4, water-quality constituent statistics) of the 13 watersheds. Two of the watersheds-Brushy Fork Creek and Richland Creek - had significantly higher stormflow TDS. Richland Creek watershed also had the highest basin slope of any of the 13 watersheds (fig. 5; table 5). For the remaining three watersheds, base-flow and stormflow TDS concentrations varied in similar, insignificantly different overlapping ranges. Variations in TDS are difficult to interpret because TDS comprises all the dissolved constituents, each with their own particular relations, into a single measure. 


\section{Water-Quality Seasonality and Long-Term Trends}

Seasonal patterns and long-term trends for 10 waterquality constituents were examined in the streamwater samples. These patterns and trends can be the result of both natural variability and human activity. The effects of variations in discharge, for which a strong relation was observed for most of the water-quality constituents in this study, have been removed by performing the trend analyses on residuals to flow-only load estimation models such that the data are flow adjusted.

\section{Seasonality in Water Quality}

Seasonality was determined from the sine and cosine model terms (eq. 2) in the flow-only load estimation models (Aulenbach and Joiner, 2017; table 3, load estimation regression models). Seasonality terms were significant for 92 of the 130 models ( 71 percent; table 10$)$. Seasonality terms were included in almost all the models for TOC, TSS, SSC, Pb, and $\mathrm{Zn}$. Seasonality terms were significant in slightly more than half of the models (7 to 9 of 13 models) for $\mathrm{TN}, \mathrm{NO}_{3}+\mathrm{NO}_{2}$, TP, and DP. Only three models had seasonality terms for TDS, which also had the lowest average seasonal range of any of the constituents. The largest seasonal ranges observed were for TP, $\mathrm{DP}$, TSS, SSC, and $\mathrm{Pb}$, though the relative importance of the seasonality on total load was less for TSS and SSC because of their much greater loads. The No Business Creek watershed exhibited the highest amount of seasonality for TSS, SSC, and $\mathrm{Pb}$. The timing of seasonality varied somewhat by constituent. All constituents, except TDS, exhibited minimums in the winter and maximums in the summer. Although the approach for assessing seasonality herein differed from that in Joiner and others (2014), these results are consistent in both magnitude and timing for the five constituents (TN, TP, TSS, Zn, and TDS) and 12 of the watersheds assessed in that report. Joiner and others (2014) found seasonality terms to be significant for all regression models fit to stormflow concentration. In the current study, seasonality terms were not included for many models. Some of these differences are likely due to (1) fitting both base-flow and stormflow samples to a single seasonality model, (2) the use of a higher $p$-value of $<0.10$ in the previous study, and (3) including additional variables in this study, such as base flow, which may have more effectively modeled seasonality.

Seasonal variations in nutrients - nitrogen, phosphorus, and carbon - can be the result of seasonal variations in biogeochemical cycling in both the terrestrial and aquatic environments as well as the result of seasonal human practices such as agriculture and fertilizer application. Seasonal patterns in suspended sediment and related particulate constituents can be the result of seasonal differences in the types of weather systems (storms) and seasonal variability in human practices. Higher suspended-sediment loads observed in the summer in this study might be related to intense summer convective thunderstorms that can result in greater storm-related erosion due to higher peak streamflows and increased transport of surficial sediments. Increased summer suspended-sediment loads may also be related to seasonal land-disturbing activities, which can result in increased washoff of sediments.

Table 10. Summary of seasonal variability in 10 water-quality constituents at the 13 LTTM program watersheds in Gwinnett County, Georgia, based on the seasonality terms in the flow-only load estimation models.

\begin{tabular}{|lccll|}
\hline \multicolumn{1}{c}{ Constituent } & $\begin{array}{c}\text { Number of } \\
\text { models with } \\
\text { seasonal terms }\end{array}$ & $\begin{array}{c}\text { Average } \\
\text { seasonal range } \\
\text { ( } \begin{array}{l}\text { natural log } \\
\text { pounds per day) }\end{array}\end{array}$ & $\begin{array}{c}\text { Typical } \\
\text { minimum month(s) }\end{array}$ & $\begin{array}{c}\text { Typical } \\
\text { maximum month(s) }\end{array}$ \\
\hline Total nitrogen & 9 & 0.16 & November-December & June \\
\hline Total nitrate plus nitrite & 9 & 0.15 & October-December & May-July \\
\hline Total phosphorus & 7 & 0.38 & January-February & July-September \\
\hline Dissolved phosphorus & 7 & 0.34 & February-April & August-September \\
\hline Total organic carbon & 12 & 0.17 & January-February & July-August \\
\hline Total suspended solids & 12 & 0.39 & December-January & June-July \\
\hline Suspended sediments & 11 & 0.41 & December-January & June-July \\
\hline Total lead & 11 & 0.45 & January-February & July-August \\
\hline Total zinc & 11 & 0.25 & November-February & May-August \\
\hline Total dissolved solids & 3 & 0.09 & Variable & Variable \\
\hline
\end{tabular}




\section{Long-Term Trends in Water Quality}

Long-term trends were determined from a linear fit of the relation of residuals of the flow-only load estimation models (with time terms excluded) versus time. These trends were determined from the same water-quality datasets used for estimating loads, with outliers removed. Significant trends in concentrations ( $p$-value $<0.05$ ) were identified in 67 of the 130 constituent-watershed combinations (52 percent of combinations; table 11) for WYs 2001-15 (15 years). There were 20 postitive trends ( 30 percent) and 47 negative trends (70 percent). Constituents exhibiting predominantly positive trends included TOC (5 watersheds) and TDS ( 9 of the 10 trends were positive). Constituents exhibiting

Table 11. Water-quality constituent trends and statistical significance for sample concentrations in 13 monitored watersheds in Gwinnett County, Georgia, for water years 2001-15.

[Bold values are significant ( $p$-value $\leq 0.05$ )]

\begin{tabular}{|c|c|c|c|c|c|c|c|c|c|c|c|}
\hline \multirow{2}{*}{$\begin{array}{c}\text { Site } \\
\text { number }\end{array}$} & \multirow{2}{*}{ Watershed } & \multicolumn{2}{|c|}{ Total nitrogen } & \multicolumn{2}{|c|}{ Total nitrate plus nitrite } & \multicolumn{2}{|c|}{ Total phosphorus } & \multicolumn{2}{|c|}{ Dissolved phosphorus } & \multicolumn{2}{|c|}{ Total organic carbon } \\
\hline & & Slope & $p$-value & Slope & $p$-value & Slope & $p$-value & Slope & $p$-value & Slope & $p$-value \\
\hline 02205865 & Sweetwater Creek $^{1}$ & 0.012 & 0.774 & -0.026 & 0.391 & -0.17 & 0.015 & 0.040 & 0.496 & -0.026 & 0.261 \\
\hline 02207185 & No Business Creek & -0.042 & 0.000 & -0.083 & 0.000 & -0.020 & 0.161 & 0.009 & 0.475 & 0.018 & 0.001 \\
\hline 02207385 & Big Haynes Creek & -0.017 & 0.003 & -0.018 & 0.001 & -0.098 & 0.000 & -0.047 & 0.001 & 0.022 & 0.022 \\
\hline 02208150 & Alcovy River & 0.009 & 0.211 & -0.007 & 0.150 & -0.047 & 0.004 & 0.020 & 0.162 & 0.028 & 0.004 \\
\hline 02217274 & Wheeler Creek & 0.010 & 0.205 & 0.008 & 0.155 & -0.058 & 0.001 & 0.004 & 0.778 & 0.013 & 0.483 \\
\hline 02218565 & Apalachee River & 0.006 & 0.451 & -0.007 & 0.210 & -0.010 & 0.555 & 0.038 & 0.006 & 0.013 & 0.066 \\
\hline 02334480 & Richland Creek & 0.005 & 0.589 & 0.013 & 0.019 & -0.067 & 0.002 & 0.028 & 0.011 & 0.007 & 0.391 \\
\hline 02336030 & $\begin{array}{l}\text { North Fork Peachtree } \\
\text { Creek }\end{array}$ & 0.005 & 0.541 & -0.019 & 0.005 & -0.053 & 0.006 & -0.005 & 0.779 & -0.013 & 0.249 \\
\hline
\end{tabular}

\begin{tabular}{|c|c|c|c|c|c|c|c|c|c|c|c|}
\hline \multirow{2}{*}{$\begin{array}{c}\text { Site } \\
\text { number }\end{array}$} & \multirow{2}{*}{ Watershed } & \multicolumn{2}{|c|}{$\begin{array}{c}\text { Total } \\
\text { suspended solids }\end{array}$} & \multicolumn{2}{|c|}{ Suspended sediment } & \multicolumn{2}{|c|}{ Total lead } & \multicolumn{2}{|c|}{ Total zinc } & \multicolumn{2}{|c|}{$\begin{array}{c}\text { Total } \\
\text { dissolved solids }\end{array}$} \\
\hline & & Slope & $p$-value & Slope & $p$-value & Slope & $p$-value & Slope & $p$-value & Slope & $p$-value \\
\hline 02207120 & Yellow River & -0.017 & 0.038 & 0.022 & 0.185 & -0.029 & 0.007 & -0.021 & 0.009 & -0.001 & 0.881 \\
\hline 02207185 & No Business Creek & -0.037 & 0.013 & -0.063 & 0.002 & -0.070 & 0.003 & -0.028 & 0.145 & -0.019 & 0.000 \\
\hline 02207400 & Brushy Fork Creek & -0.031 & 0.009 & -0.028 & 0.086 & -0.031 & 0.002 & 0.007 & 0.466 & 0.028 & 0.000 \\
\hline 02208150 & Alcovy River & -0.042 & 0.000 & -0.041 & 0.028 & -0.024 & 0.083 & 0.020 & 0.180 & 0.021 & 0.000 \\
\hline 02217274 & Wheeler Creek & -0.093 & 0.000 & -0.102 & 0.000 & -0.100 & 0.000 & -0.042 & 0.007 & 0.023 & 0.000 \\
\hline 02218565 & Apalachee River & -0.022 & 0.174 & -0.013 & 0.500 & -0.036 & 0.239 & -0.024 & 0.145 & 0.025 & 0.000 \\
\hline 02335350 & Crooked Creek & -0.026 & 0.052 & -0.041 & 0.025 & -0.042 & 0.000 & -0.011 & 0.148 & 0.018 & 0.001 \\
\hline 02336030 & $\begin{array}{l}\text { North Fork Peachtree } \\
\text { Creek }\end{array}$ & -0.050 & 0.002 & -0.068 & 0.001 & -0.067 & 0.001 & -0.056 & 0.001 & 0.018 & 0.001 \\
\hline
\end{tabular}

\footnotetext{
${ }^{1}$ Sweetwater Creek trends for period water years 2011-15.
} 
only negative trends included TP (10 watersheds), TSS (9 watersheds), SSC (7 watersheds), $\mathrm{Pb}$ (8 watersheds), and $\mathrm{Zn}$ ( 5 watersheds). The other constituents exhibited both positive and negative trends: TN ( 1 positive, 2 negative), $\mathrm{NO}_{3}+\mathrm{NO}_{2}$ ( 2 positive, 4 negative), and DP (3 positive, 1 negative).

Seven of the watersheds had four or more negative trends (Yellow River, No Business Creek, Big Haynes Creek, Wheeler Creek, Richland Creek, Suwanee Creek, and North Fork Peachtree Creek). Sweetwater Creek, Apalachee River, and Level Creek watersheds had the fewest trends, one, two, and three trends, respectively. Sweetwater Creek watershed trends were based only on $51 / 2$ years of monitoring, which makes it more difficult to detect long-term trends. Suwanee Creek and Crooked Creek watersheds had the most positive trends, three each. Trends observed herein were fairly consistent with trends identified for the period beginning as early as WY 1997 (for watersheds with monitoring data available) through WY 2011 in Joiner and others (2014) for the five constituents (TN, TP, TSS, Zn, and TDS) and 12 of the watersheds assessed in that report. Of the 60 constituent-watershed combinations evaluated in that report, 45 of the trends were the same ( 75 percent), and only one trend changed to the opposite direction (the TSS trend at North Fork Peachtree Creek watershed changed from positive to negative). Some differences in trends are to be expected when evaluating different time periods. Some differences were also likely because the earlier report used a higher $p$-value of $<0.1$ in determining the significance of the trends.

The Suwanee Creek watershed had the largest positive trends in TN (fig. 27; table 11) and $\mathrm{NO}_{3}+\mathrm{NO}_{2}$ (fig. 28) while the No Business Creek watershed had the largest negative trends of the 13 study watersheds. These trends did not appear linear, with the trends at Suwanee Creek watershed increasing more in the later part of the time period and most of the declines at No Business Creek watershed occurring before 2007 when trends began leveling off. Yellow River, Big Haynes Creek, and North Fork Peachtree Creek watersheds also exhibited a larger negative trend in $\mathrm{NO}_{3}+\mathrm{NO}_{2}$.

Trends in TP were consistently negative across the county, with the largest rates of decline observed in the Sweetwater Creek, Big Haynes Creek, and Suwanee Creek watersheds (fig. 29; table 11). Dissolved phosphorus had fewer trends, with positive trends observed for Apalachee River, Richland Creek, and Crooked Creek watersheds (fig. 30). Only the Big Haynes Creek watershed exhibited a negative trend in DP. The lack of consistency in trends between TP and DP indicates that the declines observed in TP are from the particulate portion of the constituent.

Five of the 13 watersheds exhibited positive trends in TOC (fig. 31; table 11). The largest increases were observed for the Brushy Fork Creek, Alcovy River, and Crooked Creek watersheds.
Both TSS (fig. 32; table 11) and SSC (fig. 33) were consistent in having only negative trends. The negative trends in suspended sediment were consistent with overall negative trends in several of the other predominantly particulate constituents - $\mathrm{TP}, \mathrm{Pb}$, and $\mathrm{Zn}$. The negative trends in TSS were largest for Wheeler Creek, Richland Creek, Suwanee Creek, and North Fork Peachtree Creek watersheds. The negative trends in SSC were largest for No Business Creek, Wheeler Creek, and North Fork Peachtree Creek watersheds. The trends between TSS and SSC were somewhat inconsistent. For example, Suwanee Creek had one of the larger negative trends for TSS but had no significant trend for SSC (table 11).

The large negative trends in TSS and SSC at Wheeler Creek are in contrast with the highest increases in impervious areas observed at any of these watersheds during the timeframe of the trend analysis (fig. 12). Of the other four watersheds that exhibited large increases in impervious areas (Sweetwater Creek, Yellow River, Alcovy Creek, and Apalachee River), Yellow River had a negative trend in TSS, and Alcovy Creek had negative trends in TSS and SSC. Gwinnett County has long implemented detention pond BMP requirements to reduce and mitigate the effects of impervious areas on sediment transport. The fact that suspended sediment is either staying the same or declining at the watersheds that are experiencing the highest increases in impervious areas suggests that the BMP implementation within these watersheds during this period is maintaining (within the ability to detect trends) and, in some cases, improving water quality. It is also still possible that climatic patterns may be playing a role in the TSS trends, even though no corresponding significant trends were found for annual runoff. Suspended-sediment concentrations and transport are controlled particularly by the magnitude of storm runoff rather than the amount of annual runoff. Any trends in the variations of the frequency, magnitude, and duration of storm runoff have not been assessed in this study.

Eight of the watersheds exhibited negative trends in $\mathrm{Pb}$ (fig. 34; table 11), and five of the watersheds exhibited negative trends in $\mathrm{Zn}$ (fig. 35). The largest decreases in $\mathrm{Pb}$ and $\mathrm{Zn}$ were observed for the Wheeler Creek and North Fork Peachtree Creek watersheds, respectively. Other larger decreases in $\mathrm{Pb}$ were observed for No Business Creek, Richland Creek, Suwanee Creek and North Fork Peachtree Creek watersheds. Other larger decreases in $\mathrm{Zn}$ were observed for Wheeler Creek and Richland Creek watersheds.

Nine of the 13 watersheds exhibited positive trends in TDS, whereas one watershed (No Business Creek) had a negative trend (fig. 36; table 11). The Brushy Fork Creek watershed had the highest positive trend, while the other watersheds with positive trends had similar increases. Trends in TDS were not detected for the Sweetwater Creek, Yellow River, and Richland Creek watersheds. 


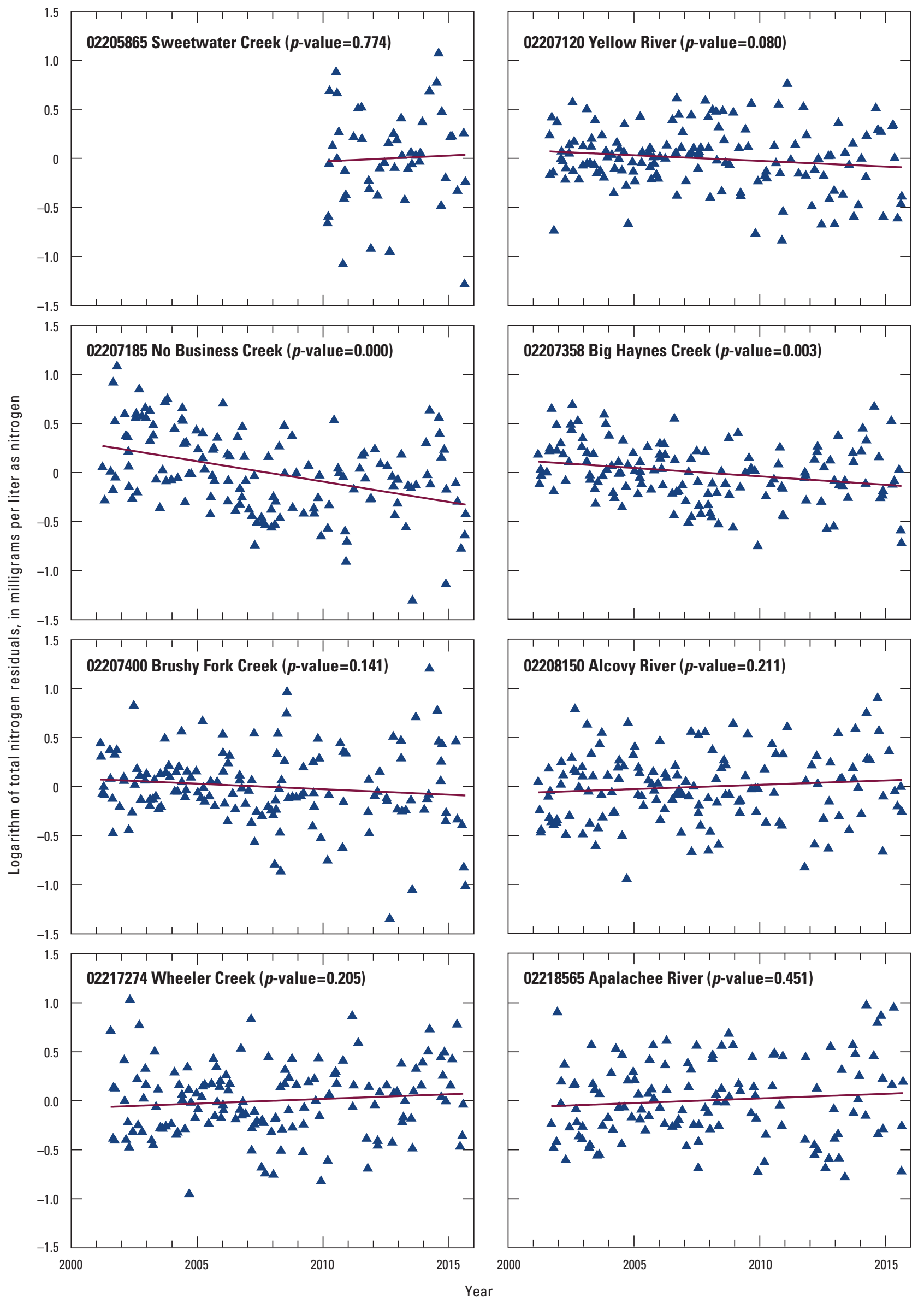




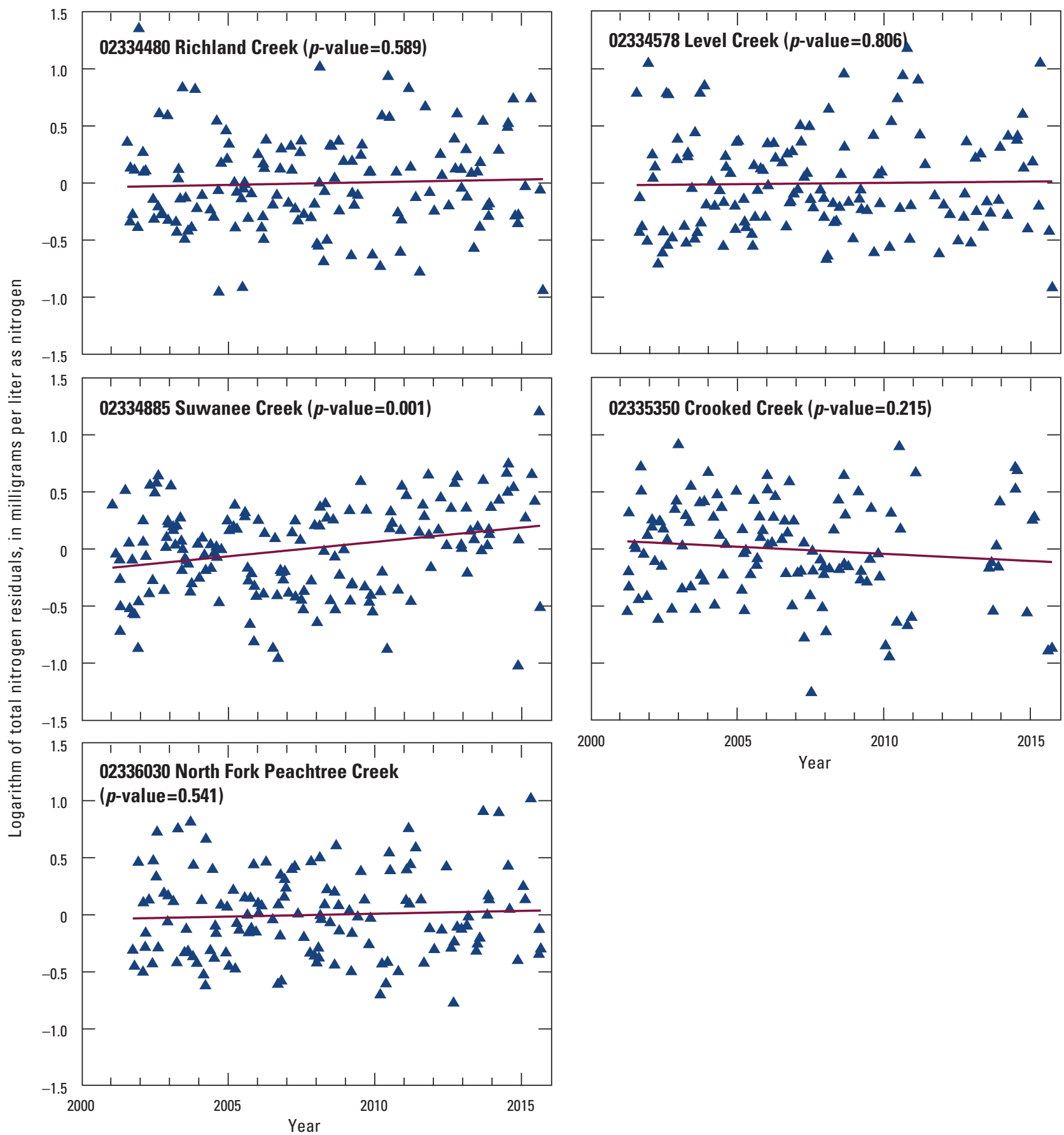

Figure 27 (pages 44 and 45). Total nitrogen residuals to flow-only load estimation model (excluding time terms) versus time for 13 monitored watersheds in Gwinnett County, Georgia. Line represents linear fit of relation between residuals and time. 


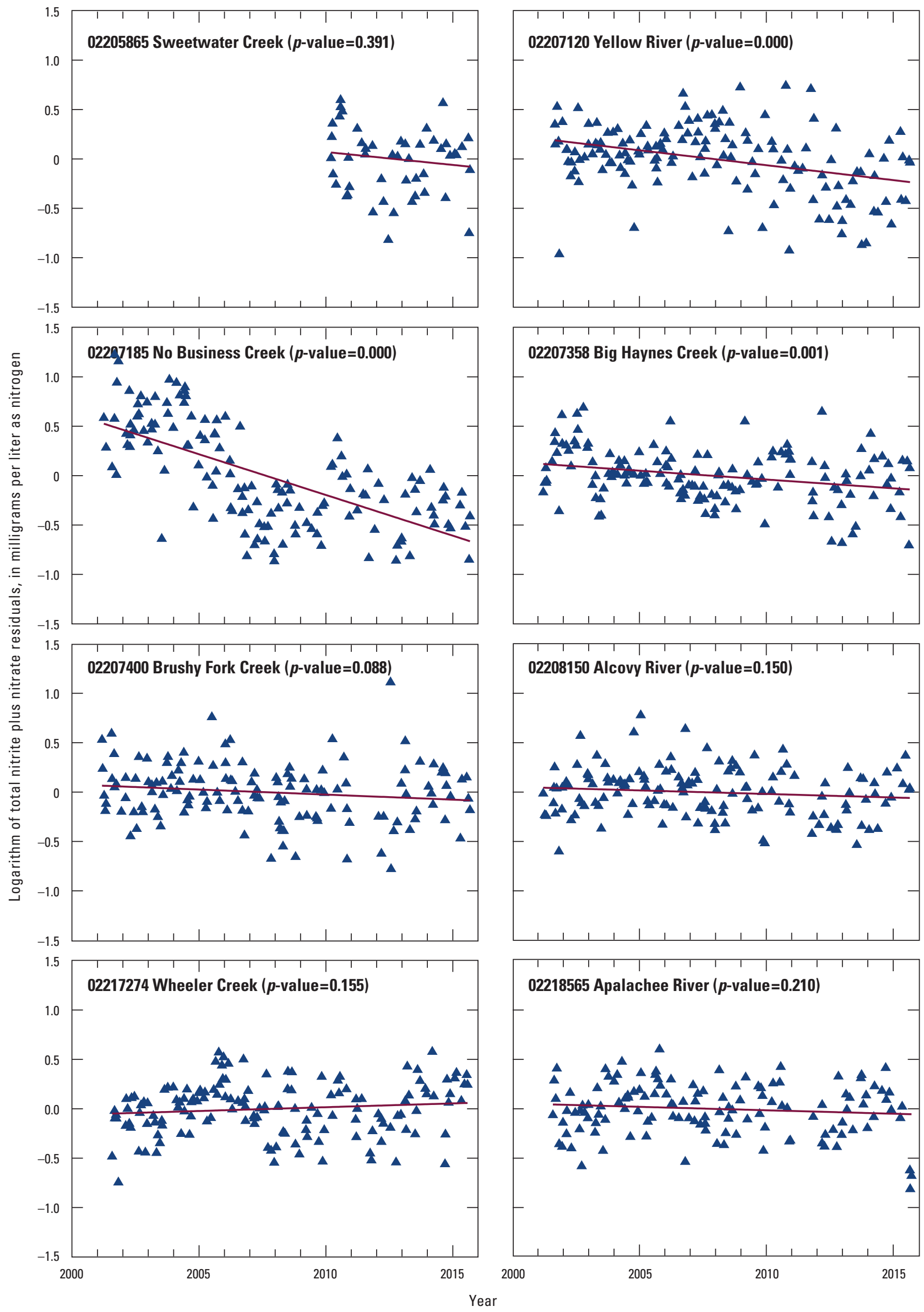




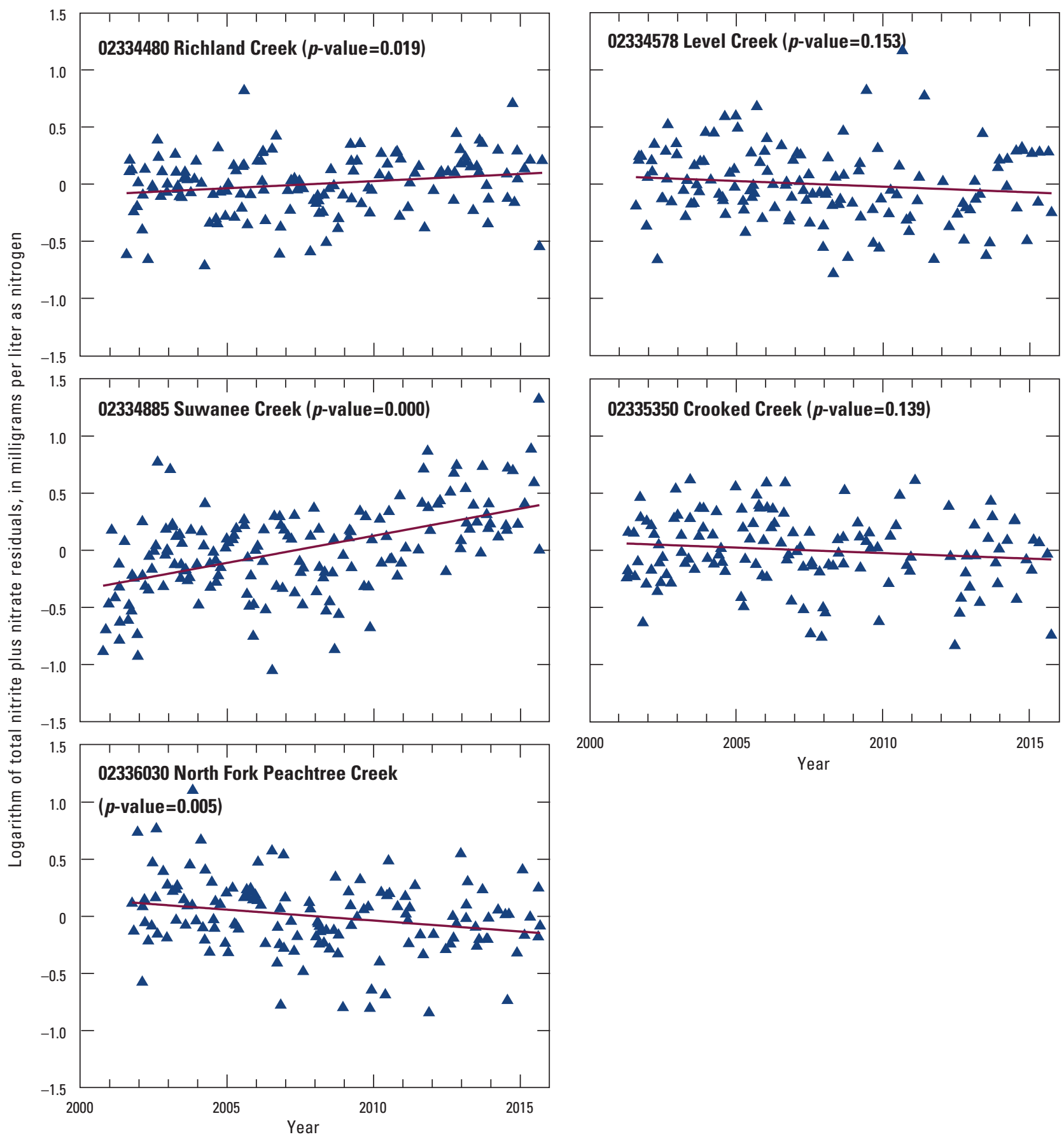

Figure 28 (pages 46 and 47). Total nitrate plus nitrite residuals to flow-only load estimation model (excluding time terms) versus time for 13 monitored watersheds in Gwinnett County, Georgia. Line represents linear fit of relation between residuals and time. 


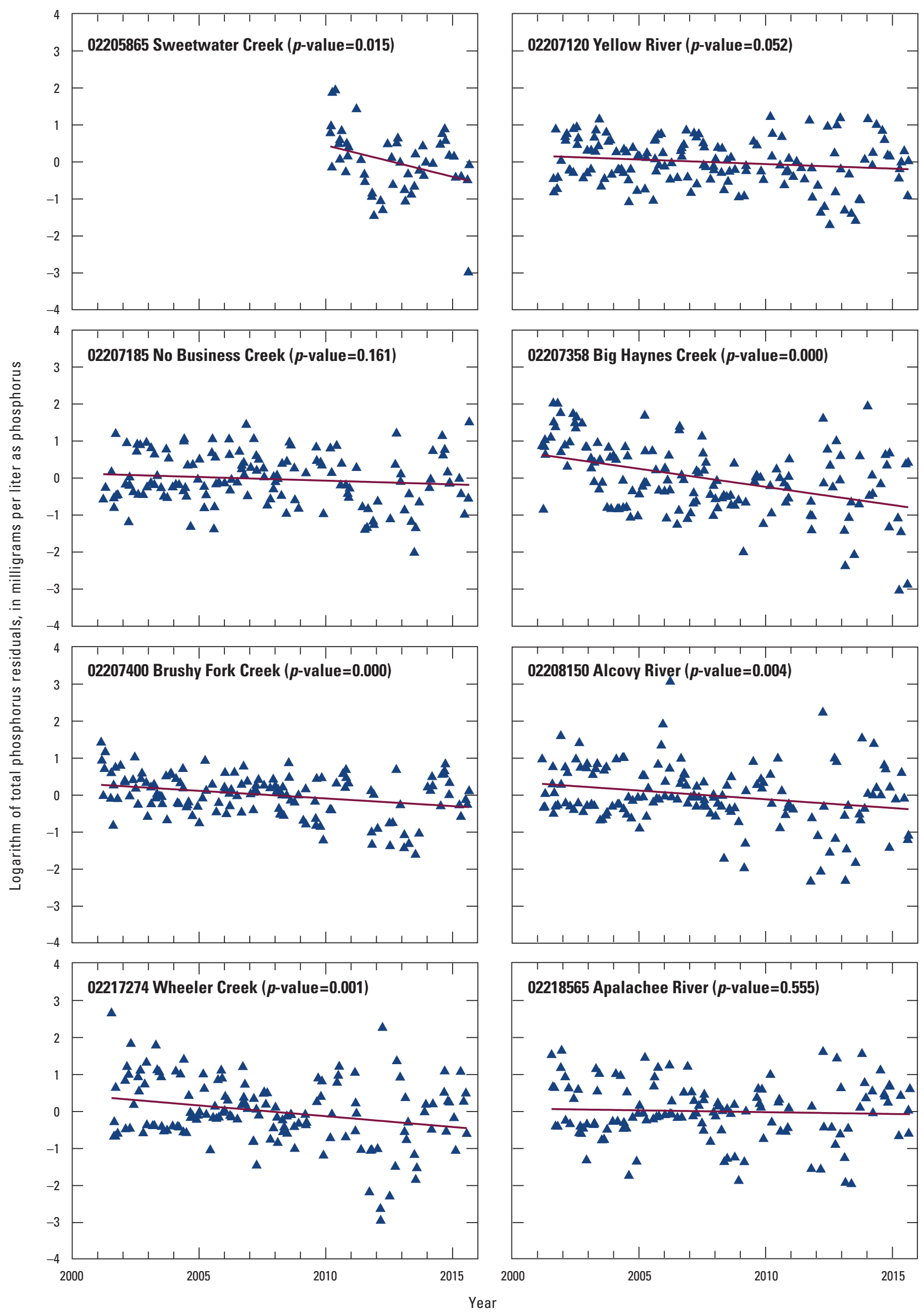




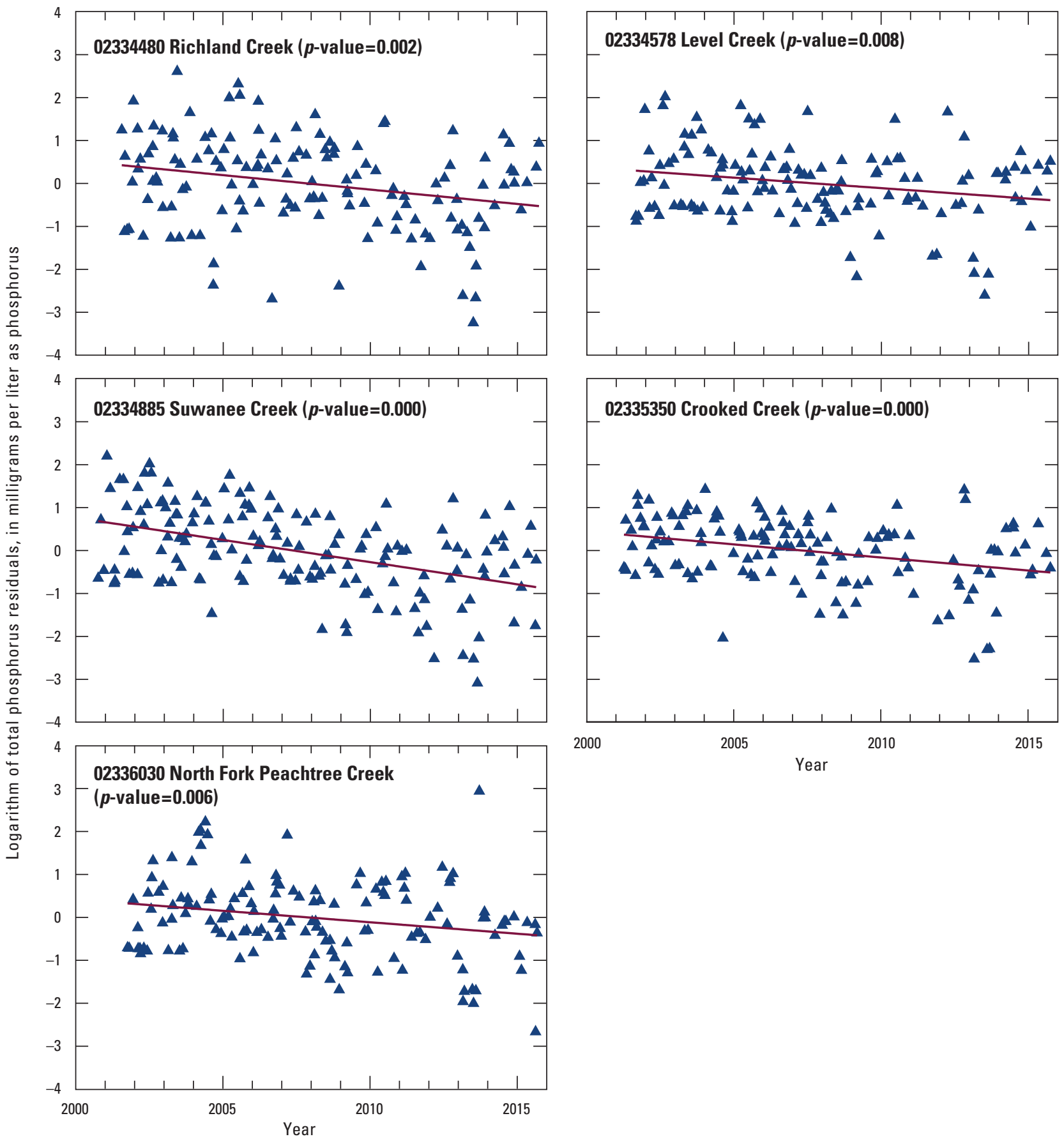

Figure 29 (pages 48 and 49). Total phosphorus residuals to flow-only load estimation model (excluding time terms) versus time for 13 monitored watersheds in Gwinnett County, Georgia. Line represents linear fit of relation between residuals and time. 


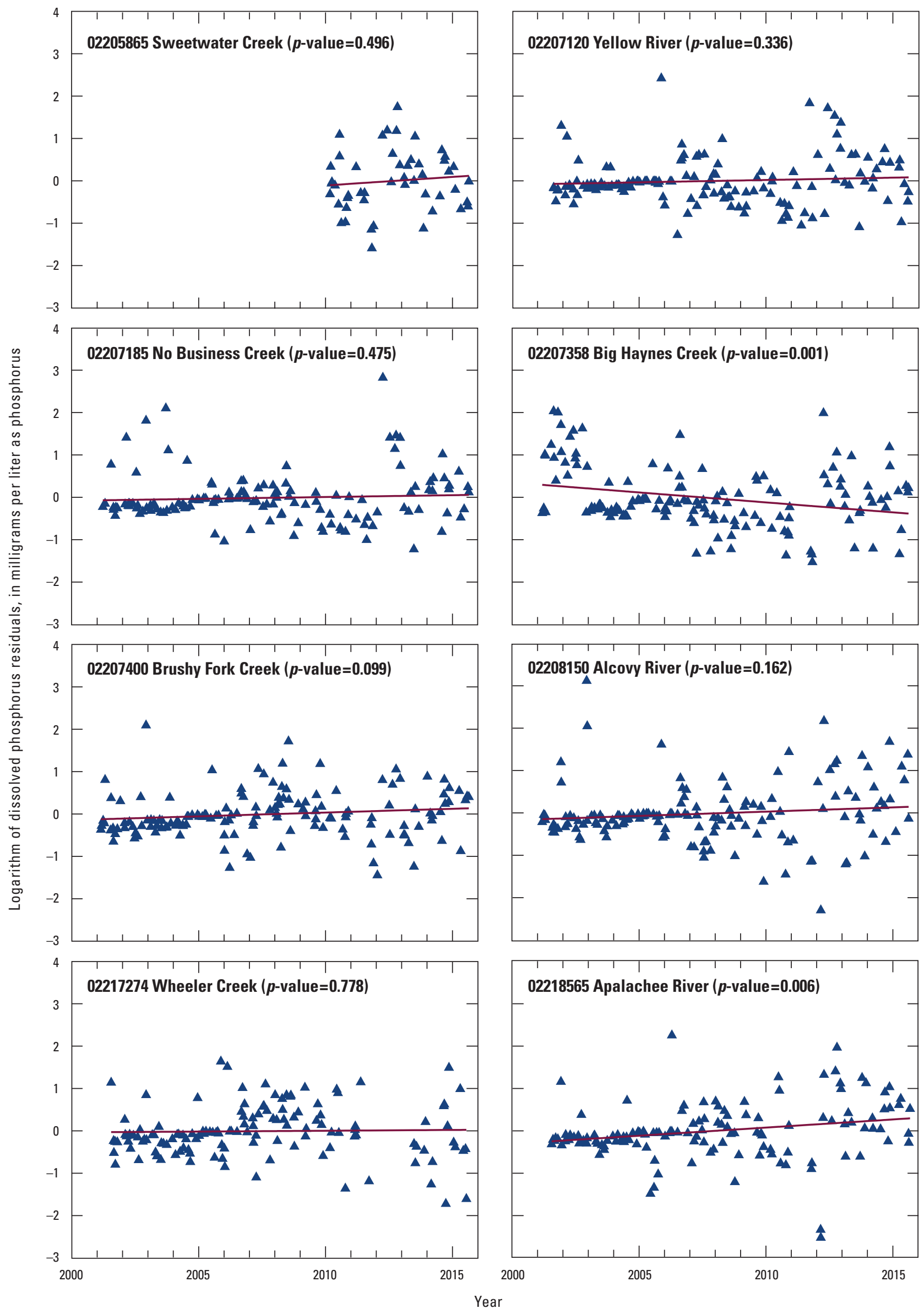




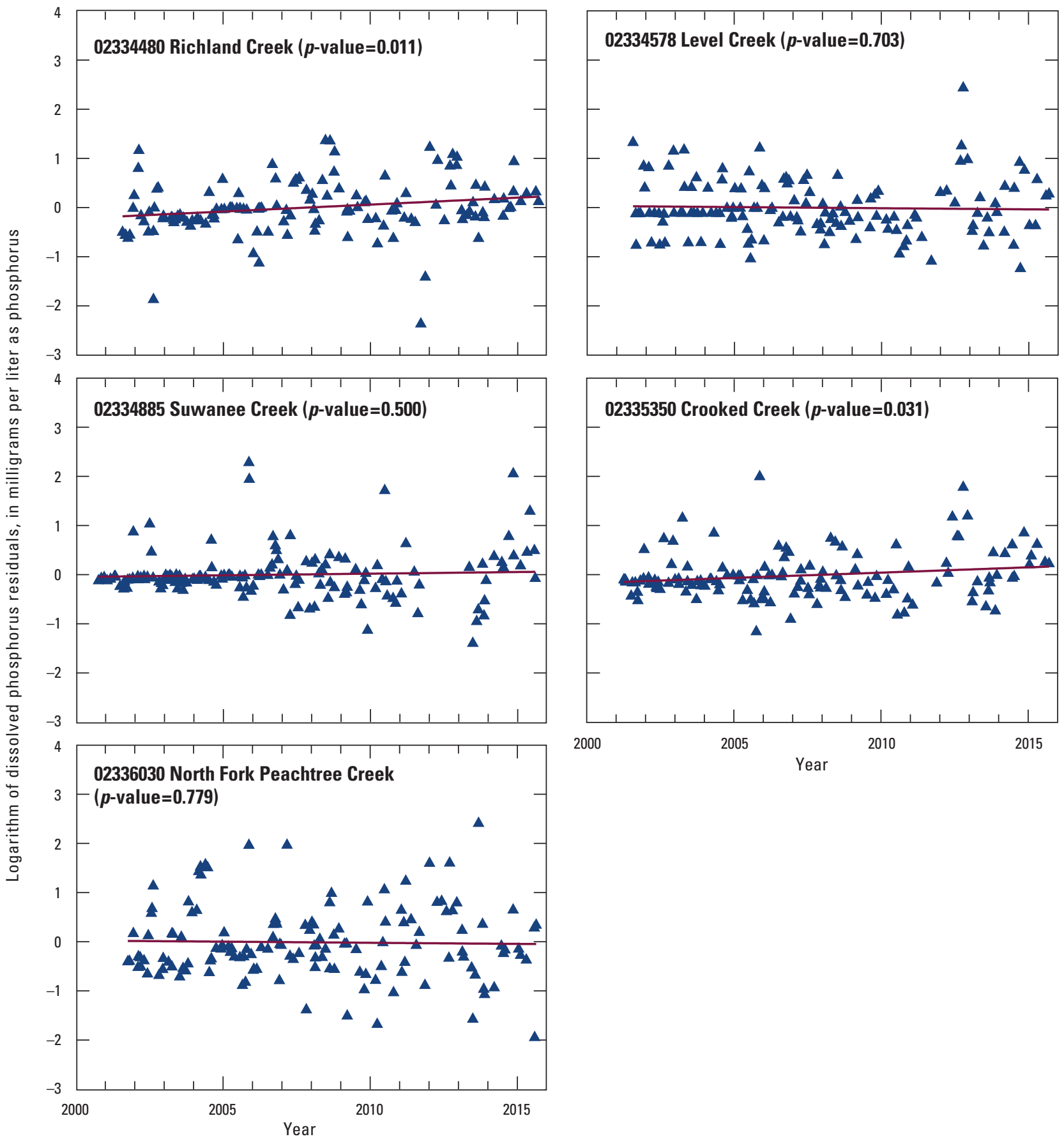

Figure 30 (pages 50 and 51). Dissolved phosphorus residuals to flow-only load estimation model (excluding time terms) versus time for 13 monitored watersheds in Gwinnett County, Georgia. Line represents linear fit of relation between residuals and time. 


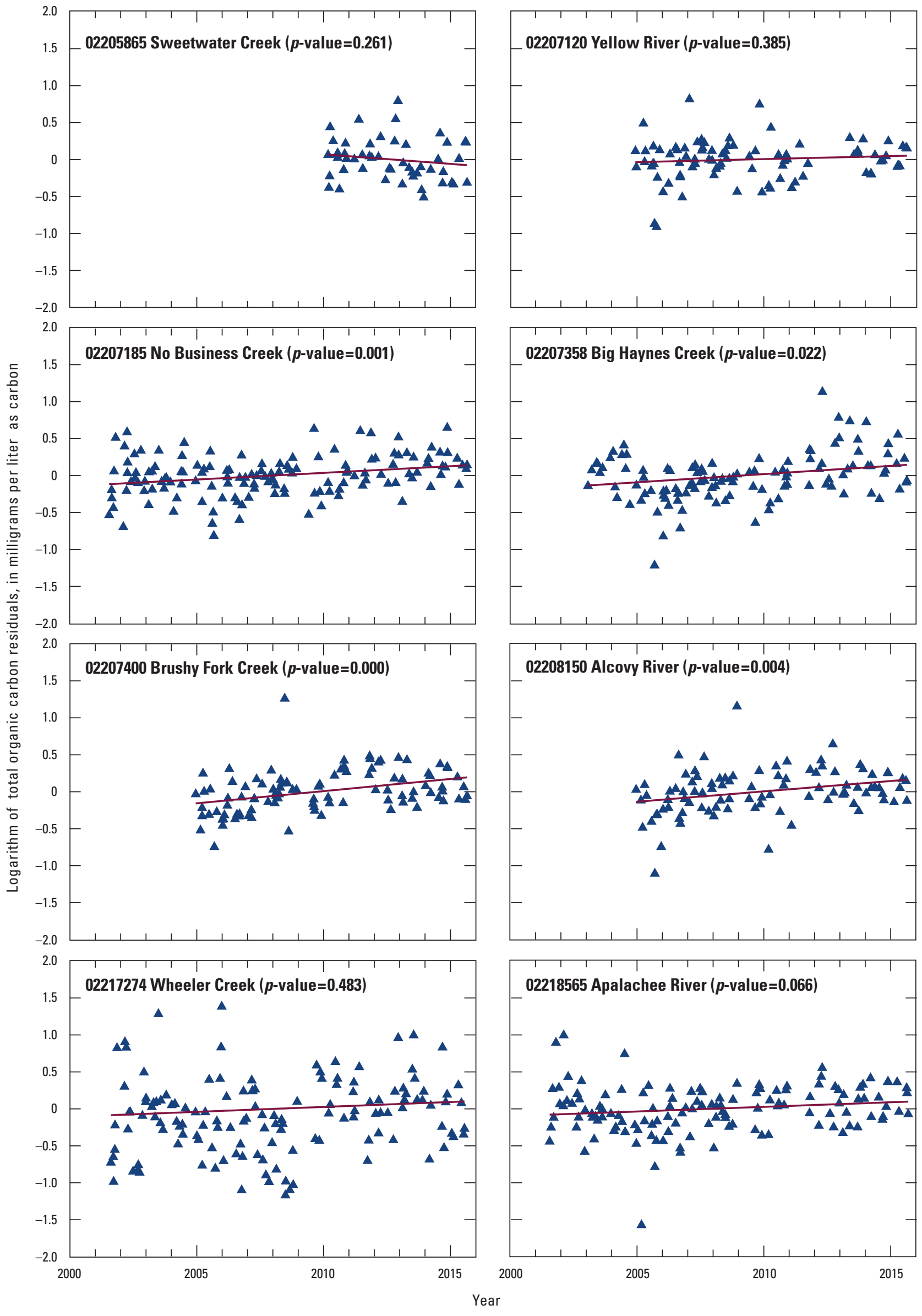




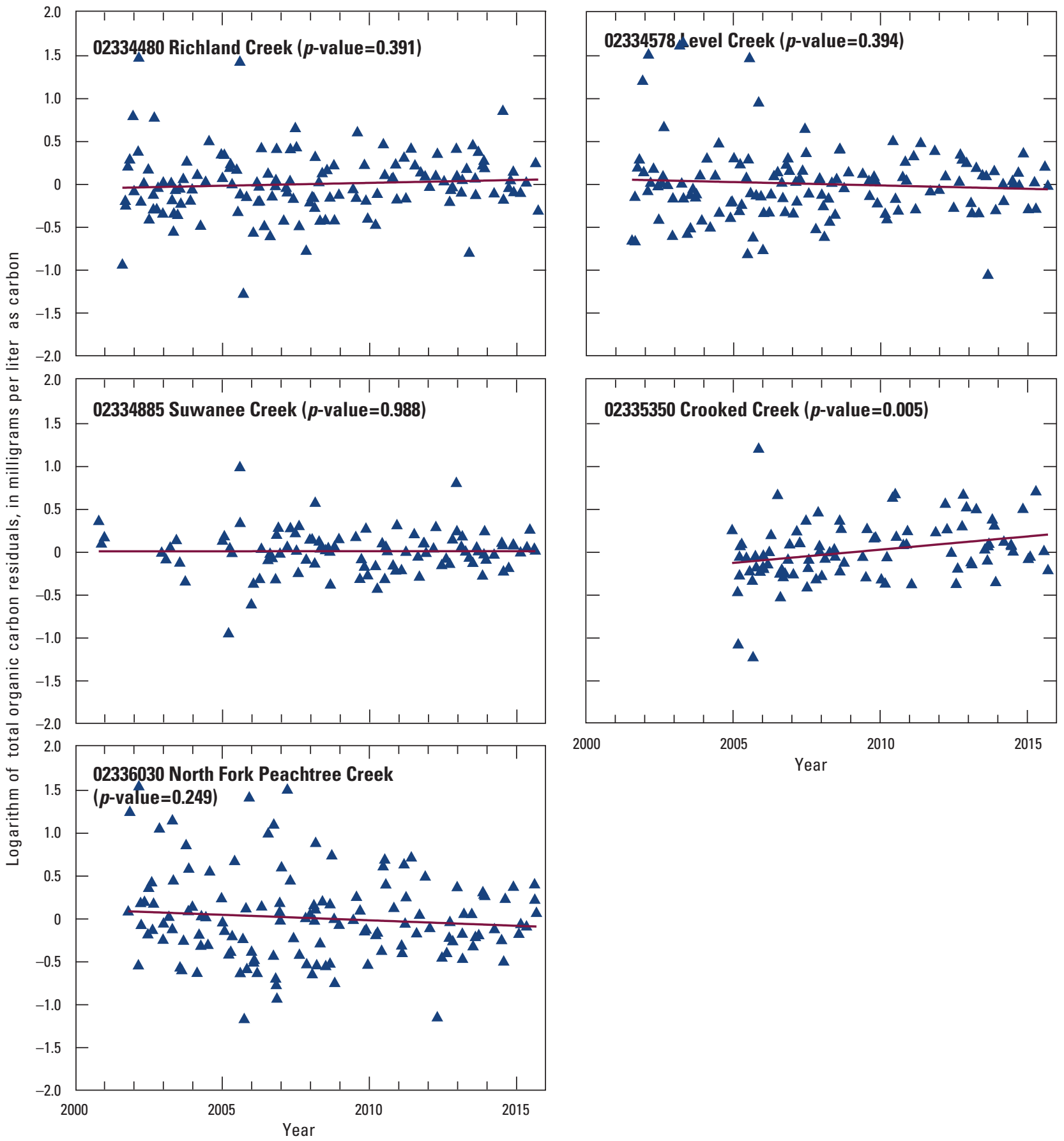

Figure 31 (pages 52 and 53). Total organic carbon residuals to flow-only load estimation model (excluding time terms) versus time for 13 monitored watersheds in Gwinnett County, Georgia. Line represents linear fit of relation between residuals and time. 


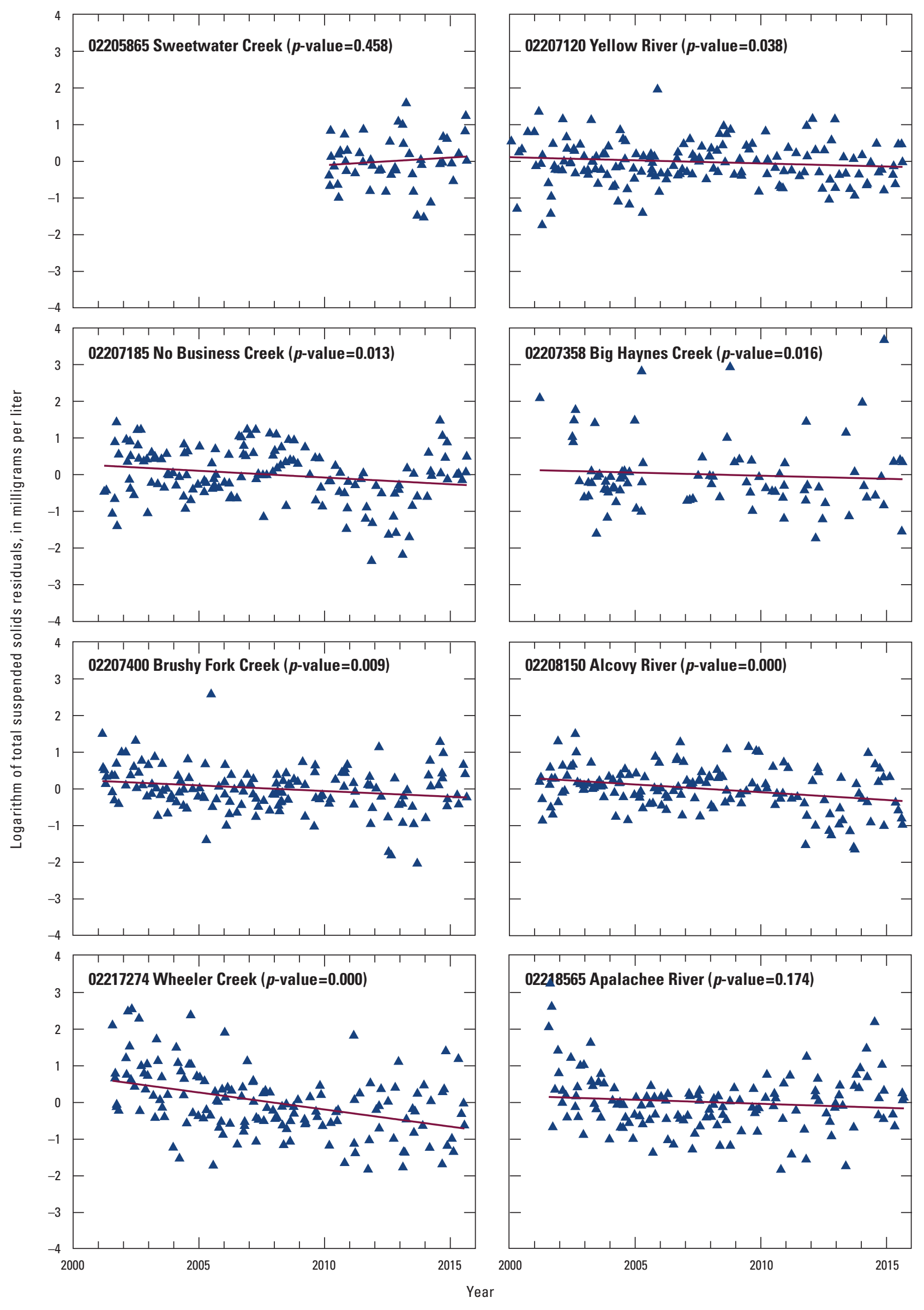




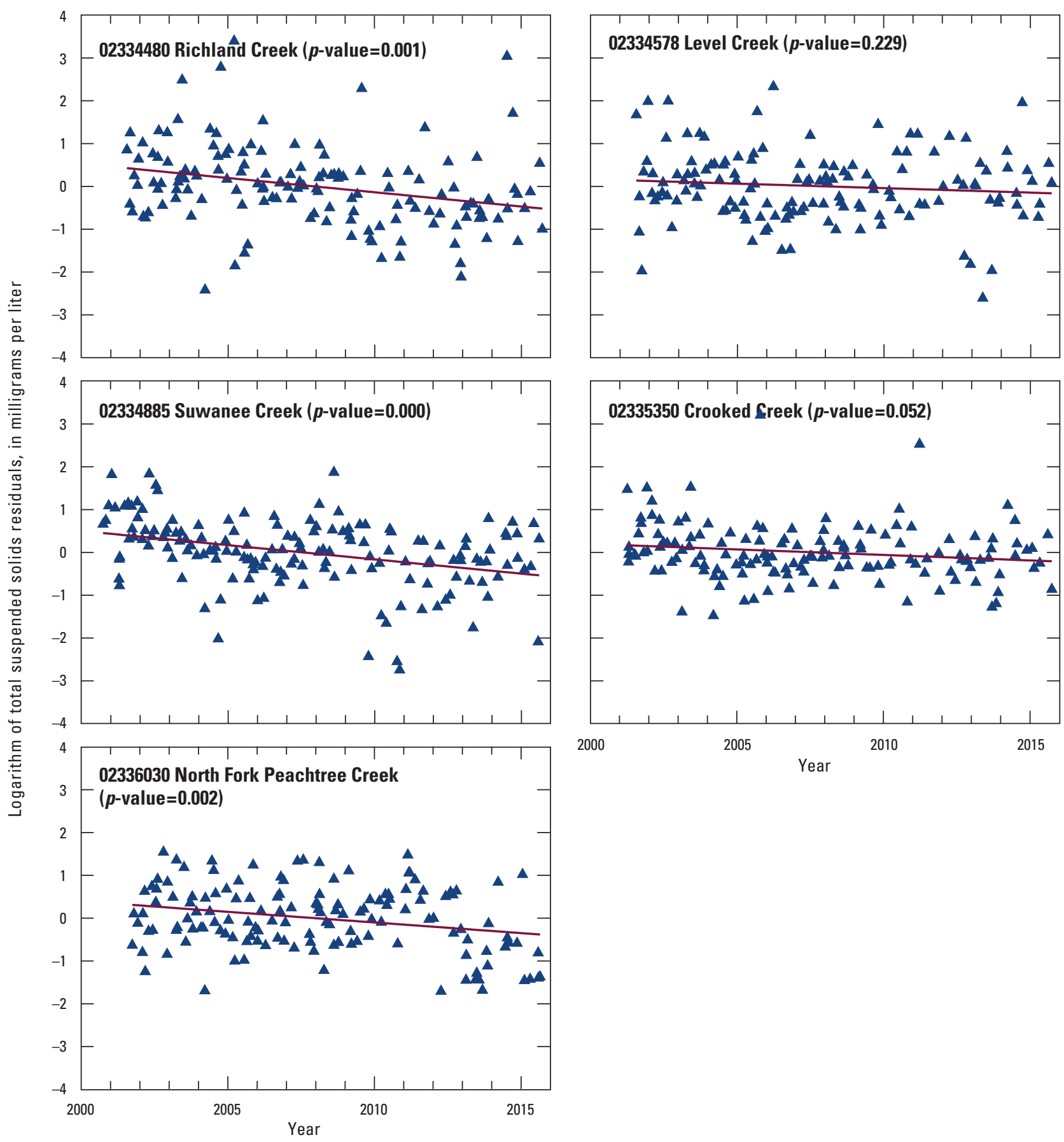

Figure 32 (pages 54 and 55). Total suspended-solid residuals to flow-only load estimation model (excluding time terms) versus time for 13 monitored watersheds in Gwinnett County, Georgia. Line represents linear fit of relation between residuals and time. 


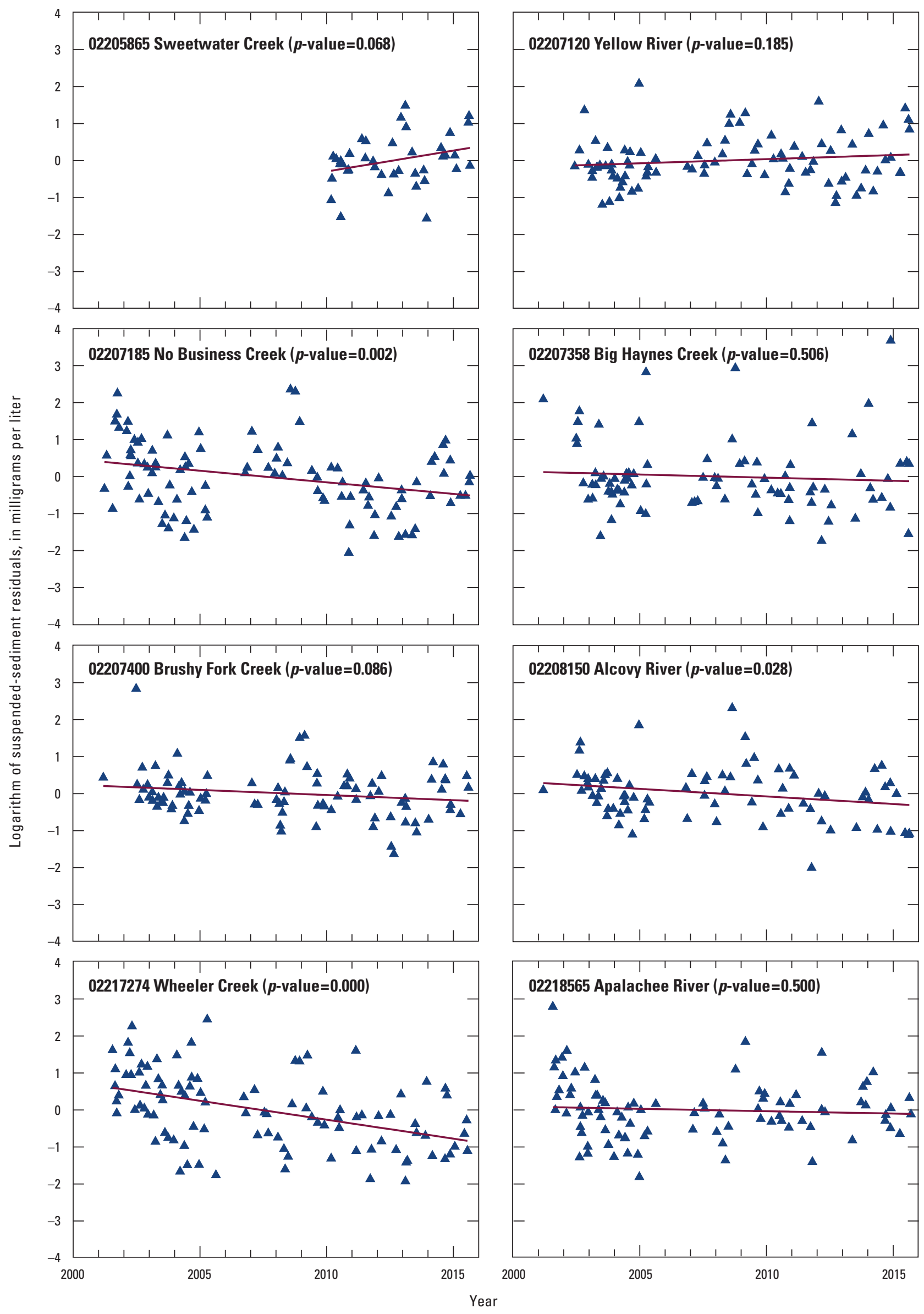




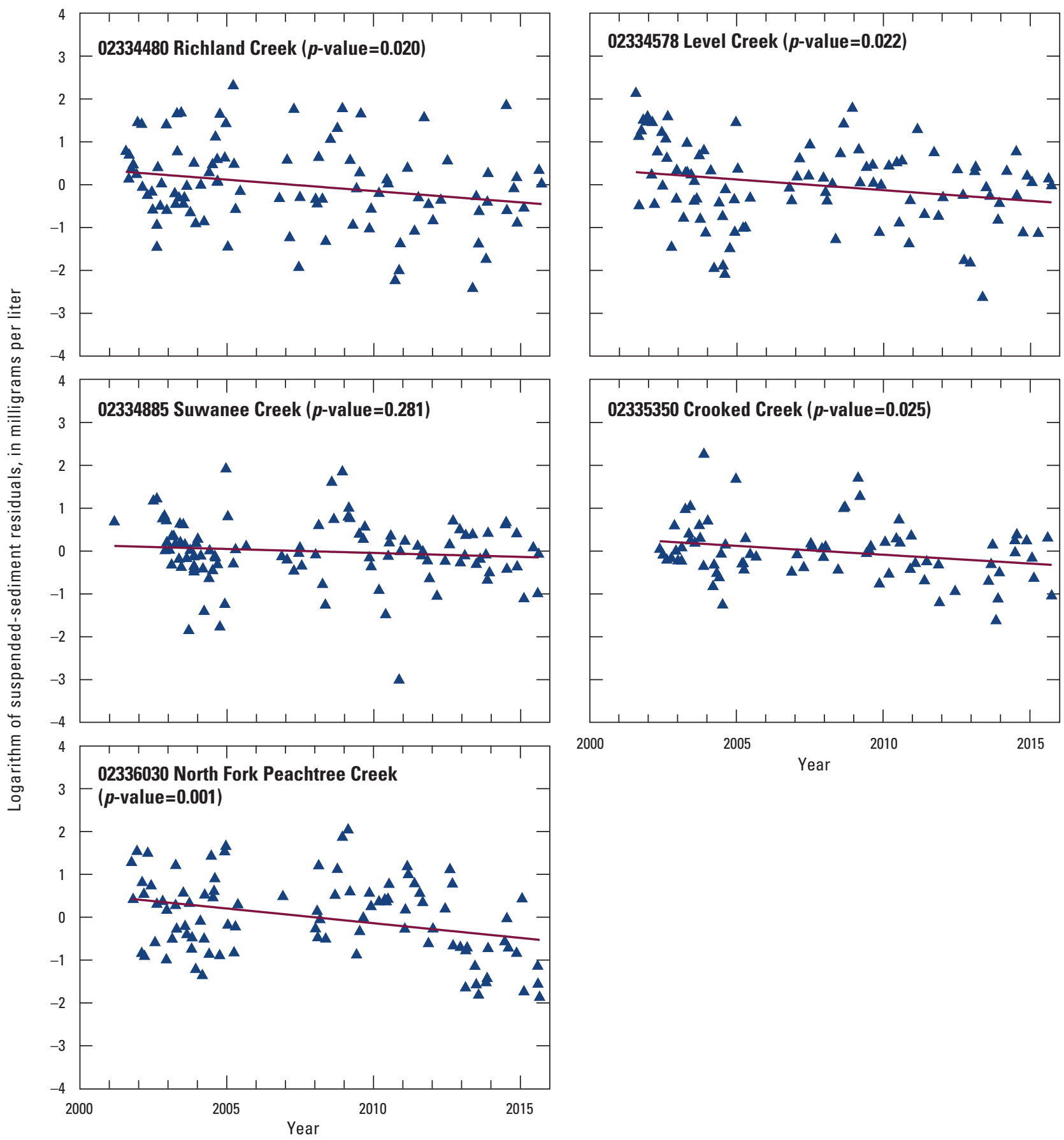

Figure 33 (pages 56 and 57). Suspended-sediment residuals to flow-only load estimation model (excluding time terms) versus time for 13 monitored watersheds in Gwinnett County, Georgia. Line represents linear fit of relation between residuals and time. 


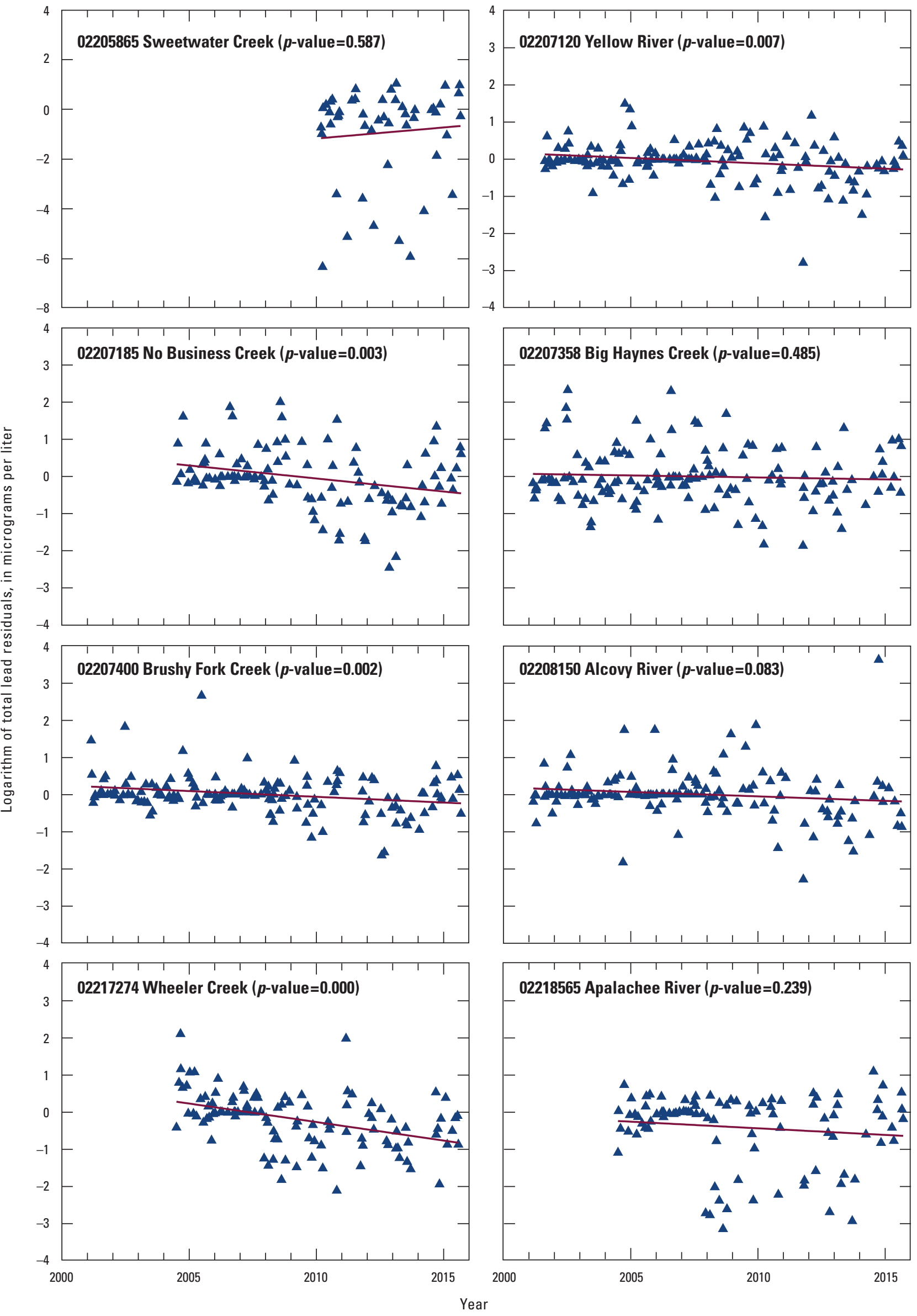




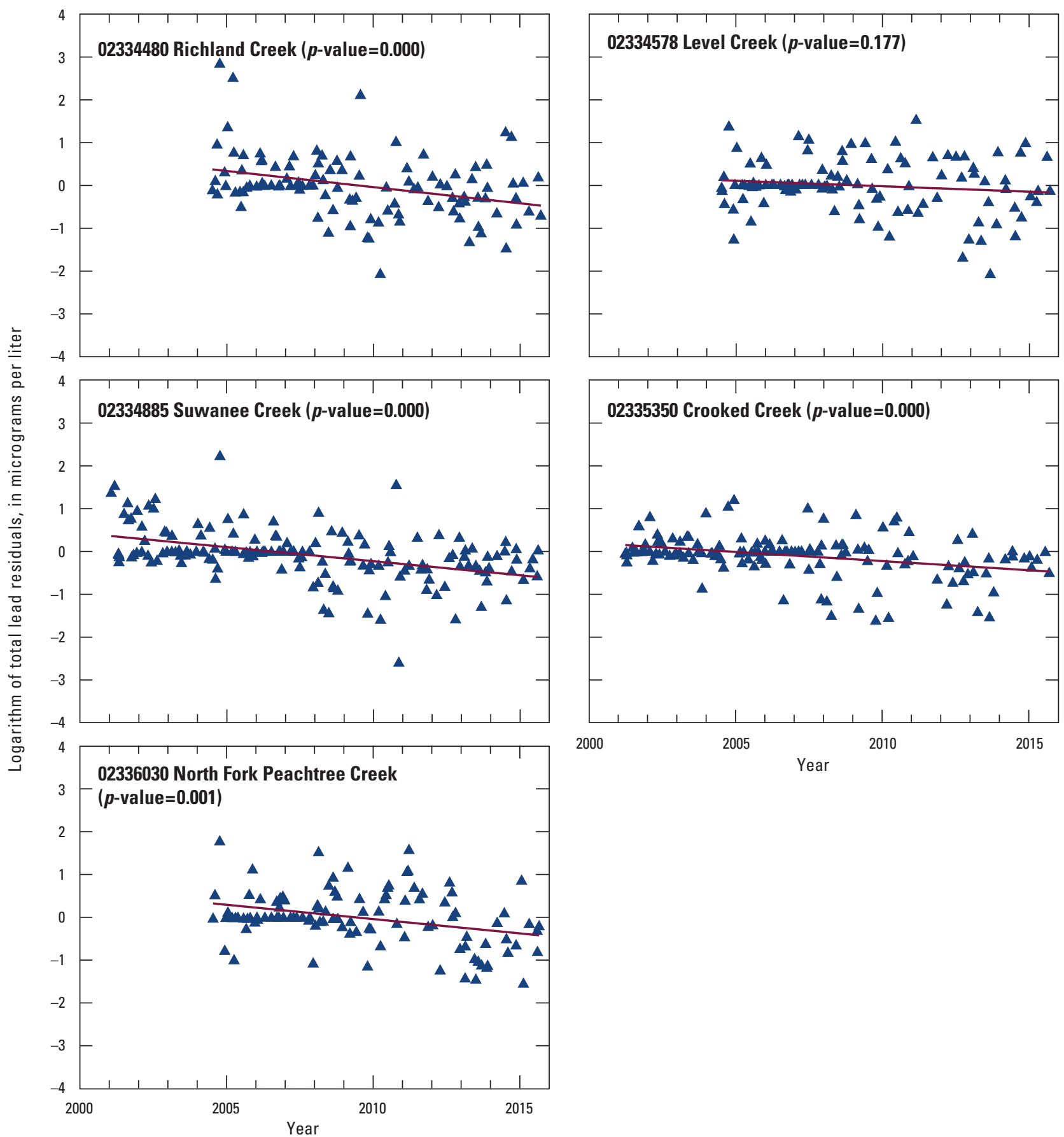

Figure 34 (pages 58 and 59). Total lead residuals to flow-only load estimation model (excluding time terms) versus time for 13 monitored watersheds in Gwinnett County, Georgia. Line represents linear fit of relation between residuals and time. 


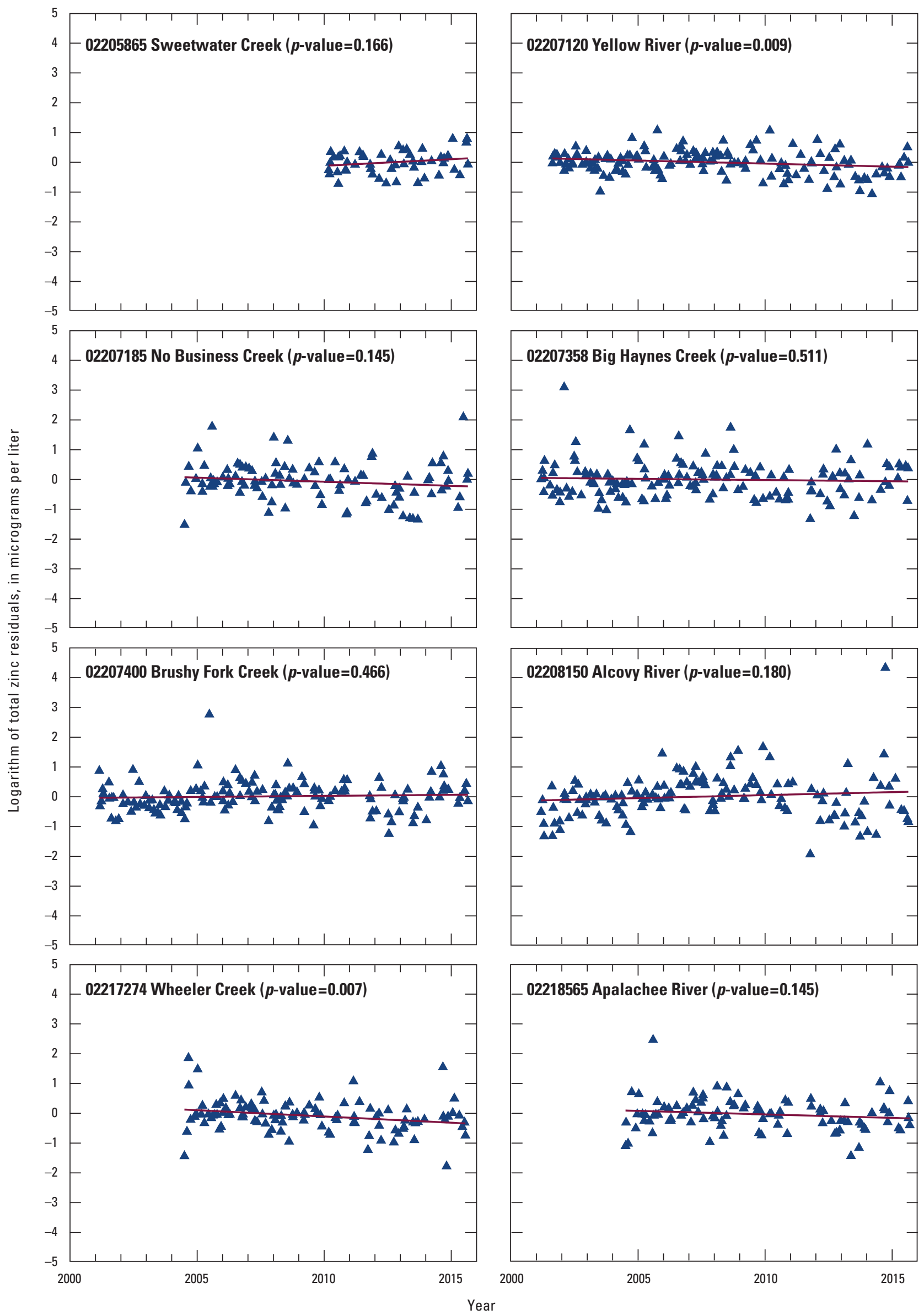



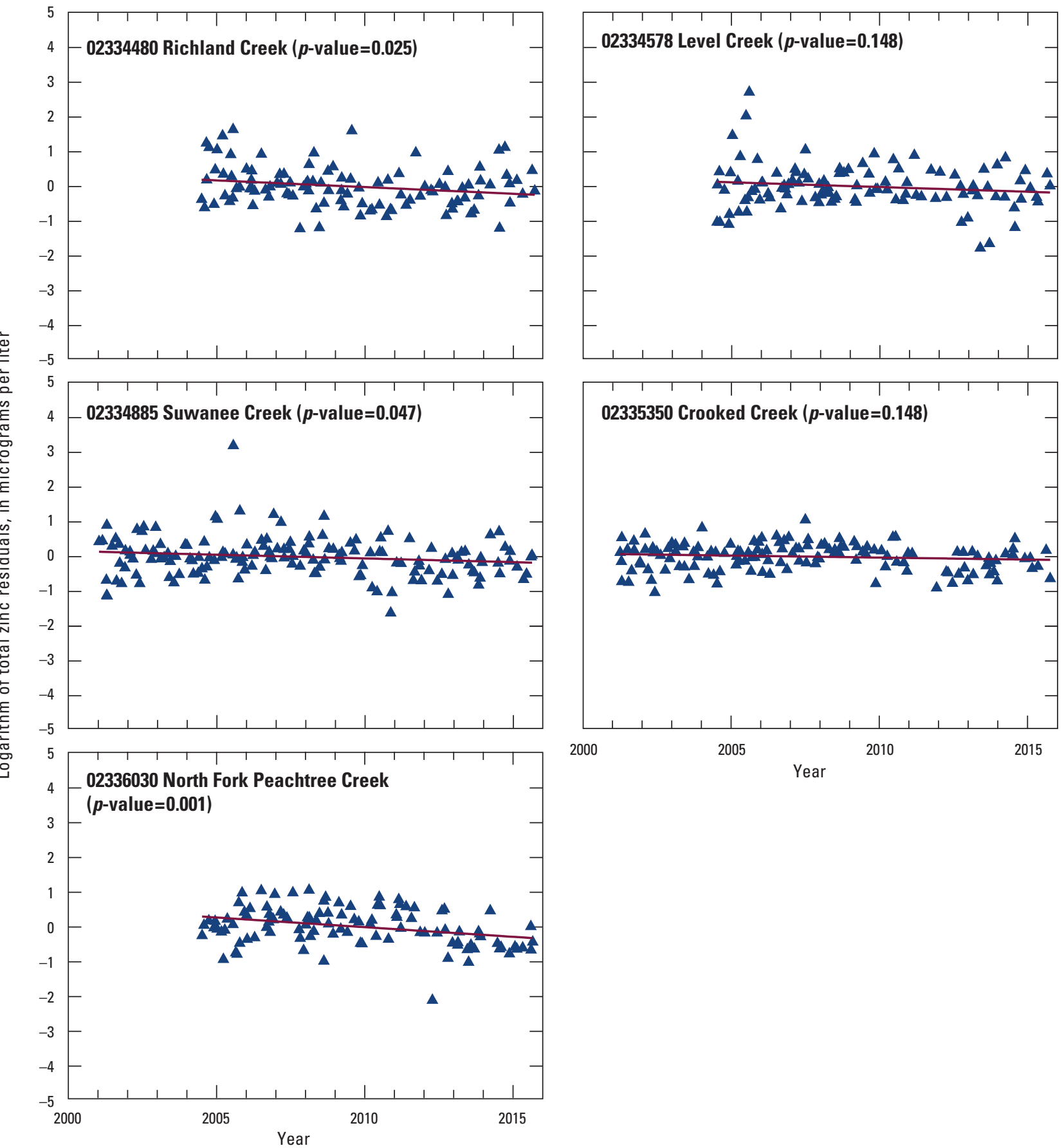

Figure 35 (pages 60 and 61). Total zinc residuals to flow-only load estimation model (excluding time terms) versus time for 13 monitored watersheds in Gwinnett County, Georgia. Line represents linear fit of relation between residuals and time. 


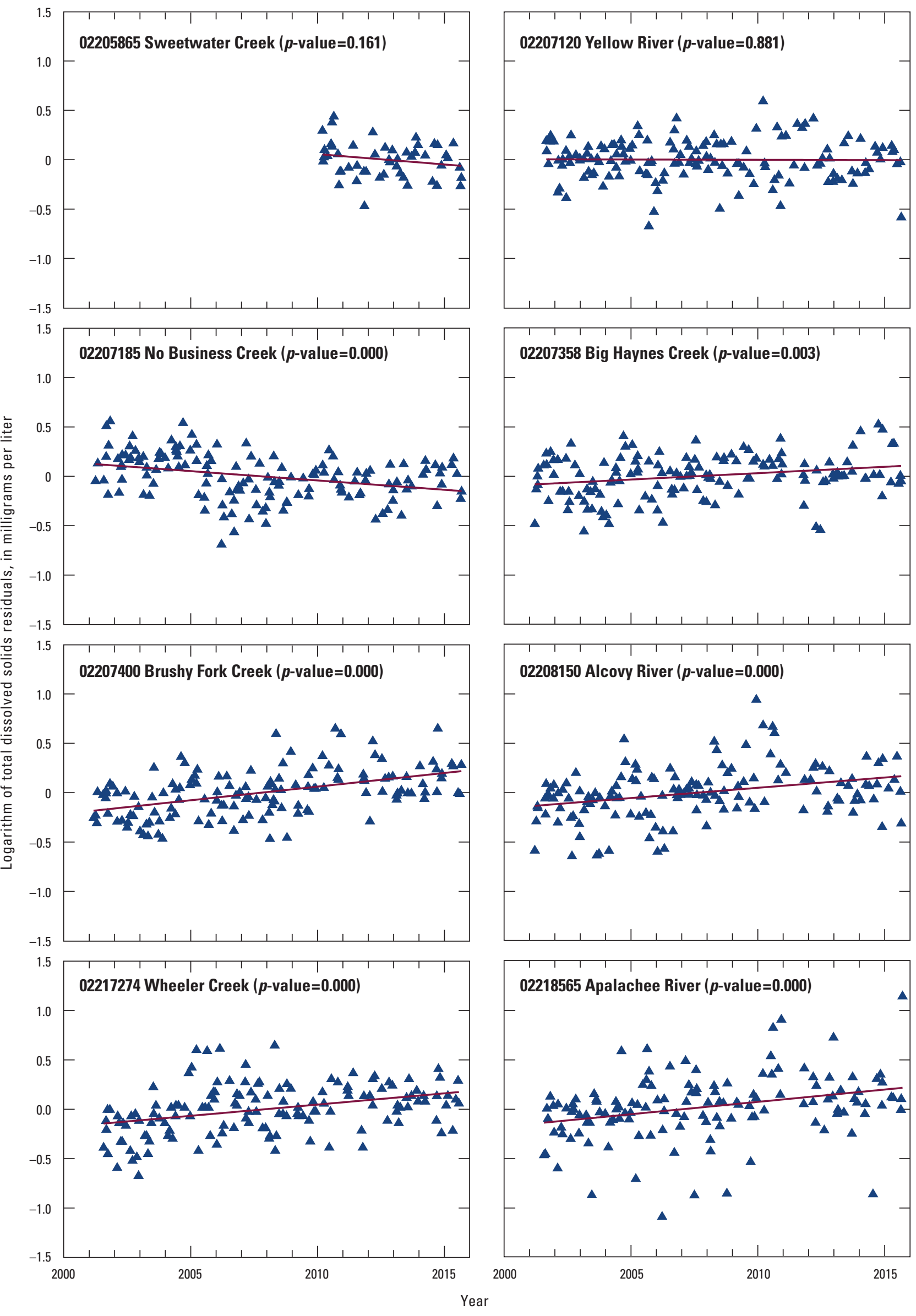




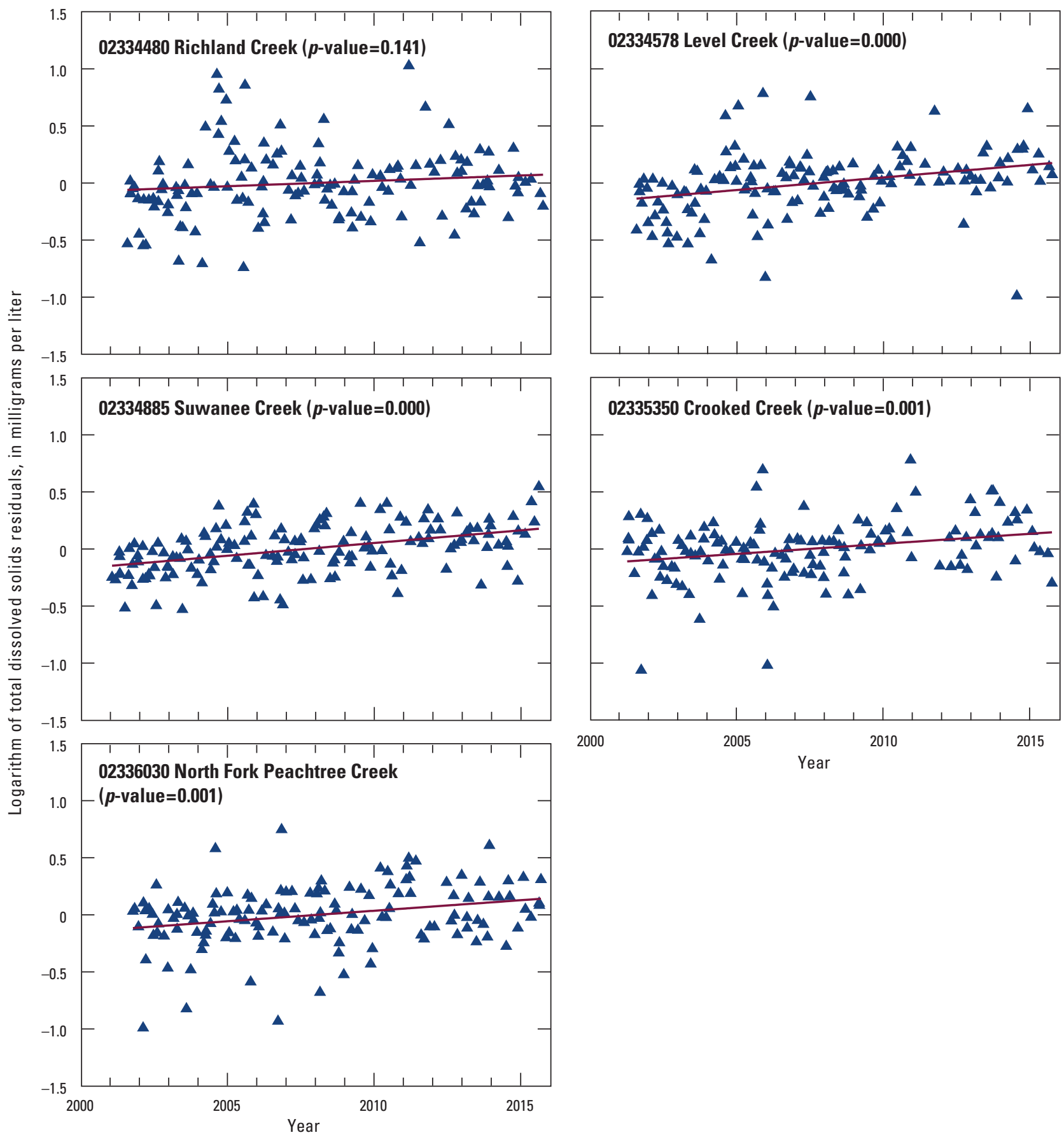

Figure 36 (pages 62 and 63). Total dissolved solids residuals to flow-only load estimation model (excluding time terms) versus time for 13 monitored watersheds in Gwinnett County, Georgia. Line represents linear fit of relation between residuals and time. 


\section{Constituent Loads and Yields}

Streamwater constituent load is the mass of chemical solutes or sediment transported at a point in a stream during a set period of time. The load estimation procedure essentially flow weights variations in concentrations during the estimation period, thereby integrating the effects of all processes within the watershed that temporally affect water quality. Yields are defined as loads per unit area and are used to allow easier comparison of the magnitude of loads among watersheds with different drainage areas.

\section{Load Models}

A total of 240 regression models were fit for estimating loads. A summary of each model is contained in Aulenbach and Joiner (2017; table 3, load estimation regression models) and includes information about the calibration dataset used, model statistics, and model parameter estimates. The coefficient of determination, $\mathrm{R}^{2}$, model statistic can be used to assess the amount of variance in the data that the model explains, with the $\mathrm{R}^{2}$ indicating the fractional amount of variance explained. Note that the $\mathrm{R}^{2} \mathrm{~s}$ are reported for models fit to loads and are inflated relative to models that are fit to concentrations, because stream discharge is contained in both sides of load equations resulting in an increase in variance explained. There were 20 constituent-watershed combinations where turbidity terms were not significant and no flow-turbidity model was fit. This was typically the situation for the dissolved constituents DP and TDS because turbidity is a surrogate for particulates. The model calibration datasets averaged about 124 samples. About 10 percent of the sample concentrations were censored, indicating that the concentrations were below the analytical detection limits. Overall, 246 outliers were removed from the calibration datasets, 1.5 percent of the total number of concentrations.

The terms included in the models can be informative in understanding which variables were useful in explaining the variations in the sample concentrations. The storm intercept term was significant in 43 percent of the models, indicating that there was often a different intercept between base-flow and stormflow concentrations. The discharge-squared, discharge during base-flow conditions, and base-flow terms were each significant in about one-third of the models. The turbidity terms in the flow-turbidity models were about equally split between fitting the model for all flow conditions or just the stormflow condition. Generally only one of the turbidity terms was significant with the exception of five models. Seasonal terms were included in 68 percent of the models. Long-term time terms were included in 60 percent of the models for the linear term and in 33 percent of the models for the squared term. The time trend terms were reasonably consistent in significance and in direction as the long-term trends identified in the model residuals presented above.

\section{Program Area Loads and Trends}

Constituent loads were summarized for the entire monitoring study area for the period WYs 2003-15 (table 12). These loads are dominated by the three largest watersheds in the study area (table 5), Yellow River, Alcovy River, and Suwanee Creek, which made up 78.1 percent of the drainage area. The annual loads had a large range in magnitudes. The most important factor related to the variability in annual loads for all 10 constituents is the amount of annual runoff (fig. 37). Annual runoff and all loads were lowest in WY 2012 and highest in WY 2003. Annual average concentrations were calculated in order to normalize the loads for the amount of annual runoff and determine how concentrations change temporally. These concentrations were calculated by dividing the annual load by the annual runoff (fig. 38). For constituents where concentrations become more dilute at higher streamflow- $\mathrm{TN}, \mathrm{NO}_{3}+\mathrm{NO}_{2}$, and TDS-higher annual average concentrations were observed for years with lower annual runoff. Total phosphorus, TOC, TSS, SSC, Pb, and $\mathrm{Zn}$ concentrations increased with higher streamflow, and annual average concentrations were higher for years with higher annual runoff. Annual average DP concentrations did not show any pattern associated with annual runoff. 
Table 12. Runoff and water-quality constituent load averages, annual minimum, annual maximum, trends, and trend statistical significance for water years 2003-15 for the LTTM program study area, Gwinnett County, Georgia.

[Bold values are significant $(p$-value $\leq 0.05)]$

\begin{tabular}{|c|c|c|c|c|c|c|}
\hline \multirow{2}{*}{ Variable } & \multirow{2}{*}{ Units } & \multirow{2}{*}{ Average } & \multirow{2}{*}{$\begin{array}{c}\text { Annual } \\
\text { minimum }\end{array}$} & \multirow{2}{*}{$\begin{array}{c}\text { Annual } \\
\text { maximum }\end{array}$} & \multicolumn{2}{|c|}{ Trend } \\
\hline & & & & & (per year) & $p$-value \\
\hline Runoff & Inches & 21.9 & 11.1 & 38.7 & -0.96 & 0.139 \\
\hline Total nitrogen & Pounds per day nitrogen & 4,240 & 2,340 & 7,760 & -220 & 0.049 \\
\hline Total nitrate plus nitrite & Pounds per day nitrogen & 2,550 & 1,700 & 3,950 & -120 & 0.005 \\
\hline Total phosphorus & Pounds per day phosphorus & 187 & 55.1 & 552 & -24 & 0.016 \\
\hline Dissolved phosphorus & Pounds per day phosphorus & 35.3 & 19.9 & 56.7 & -0.87 & 0.369 \\
\hline Total organic carbon & Pounds per day carbon & 9,370 & 4,270 & 18,700 & -490 & 0.149 \\
\hline Total suspended solids & Pounds per day & 420,000 & 95,100 & $1,320,000$ & $-57,000$ & 0.028 \\
\hline Suspended sediment & Pounds per day & 742,000 & 185,000 & $2,000,000$ & $-87,000$ & 0.040 \\
\hline Total lead & Pounds per day & 15.7 & 3.34 & 55.0 & -2.1 & 0.024 \\
\hline Total zinc & Pounds per day & 81.2 & 26.8 & 197 & -8.3 & 0.030 \\
\hline Total dissolved solids & Pounds per day & 200,000 & 123,000 & 303,000 & $-4,900$ & 0.289 \\
\hline
\end{tabular}



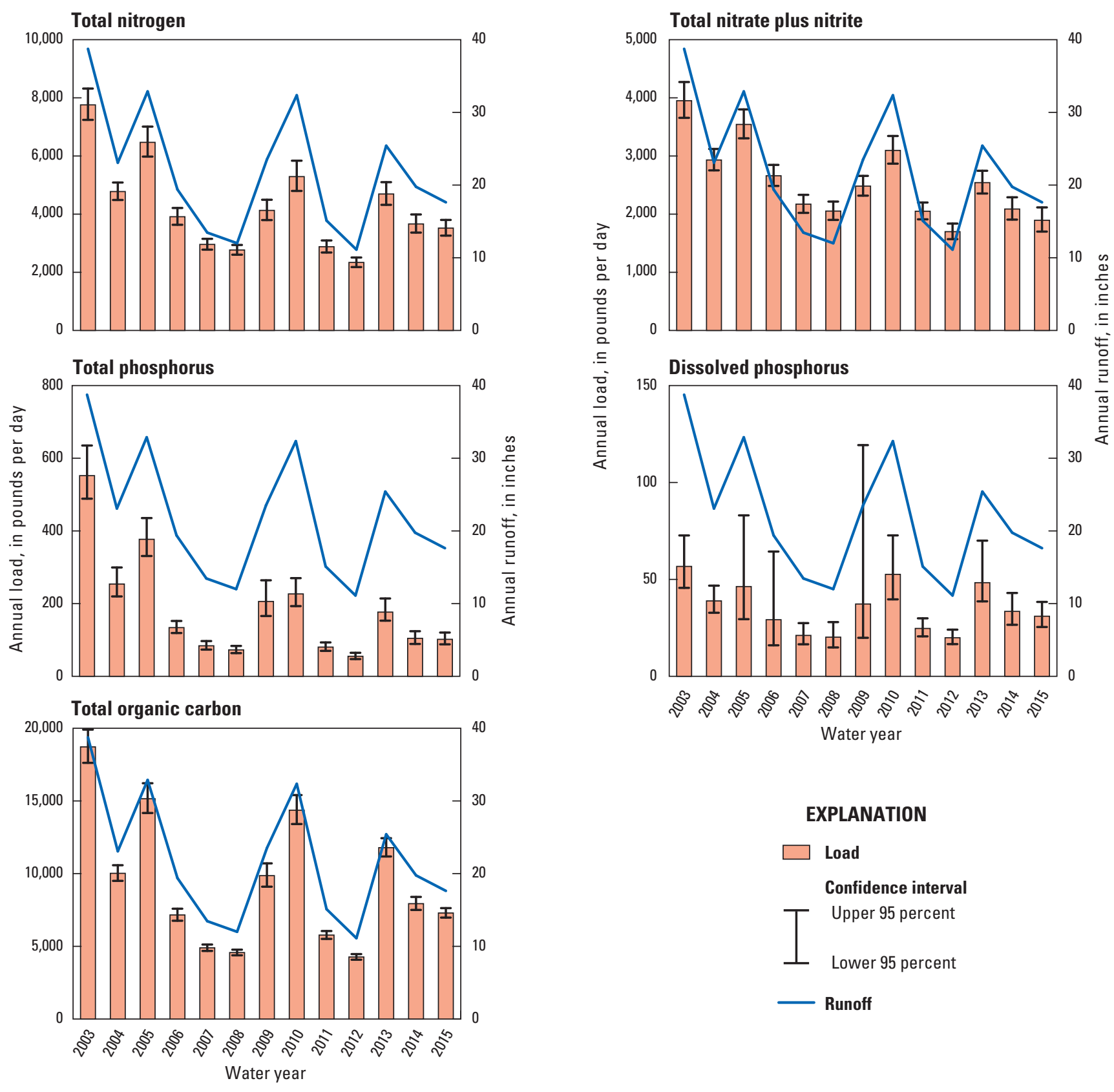

Figure 37. Annual loads and annual runoff for water years 2003-15 for the LTTM program study area in Gwinnett County, Georgia. 
Total suspended solids
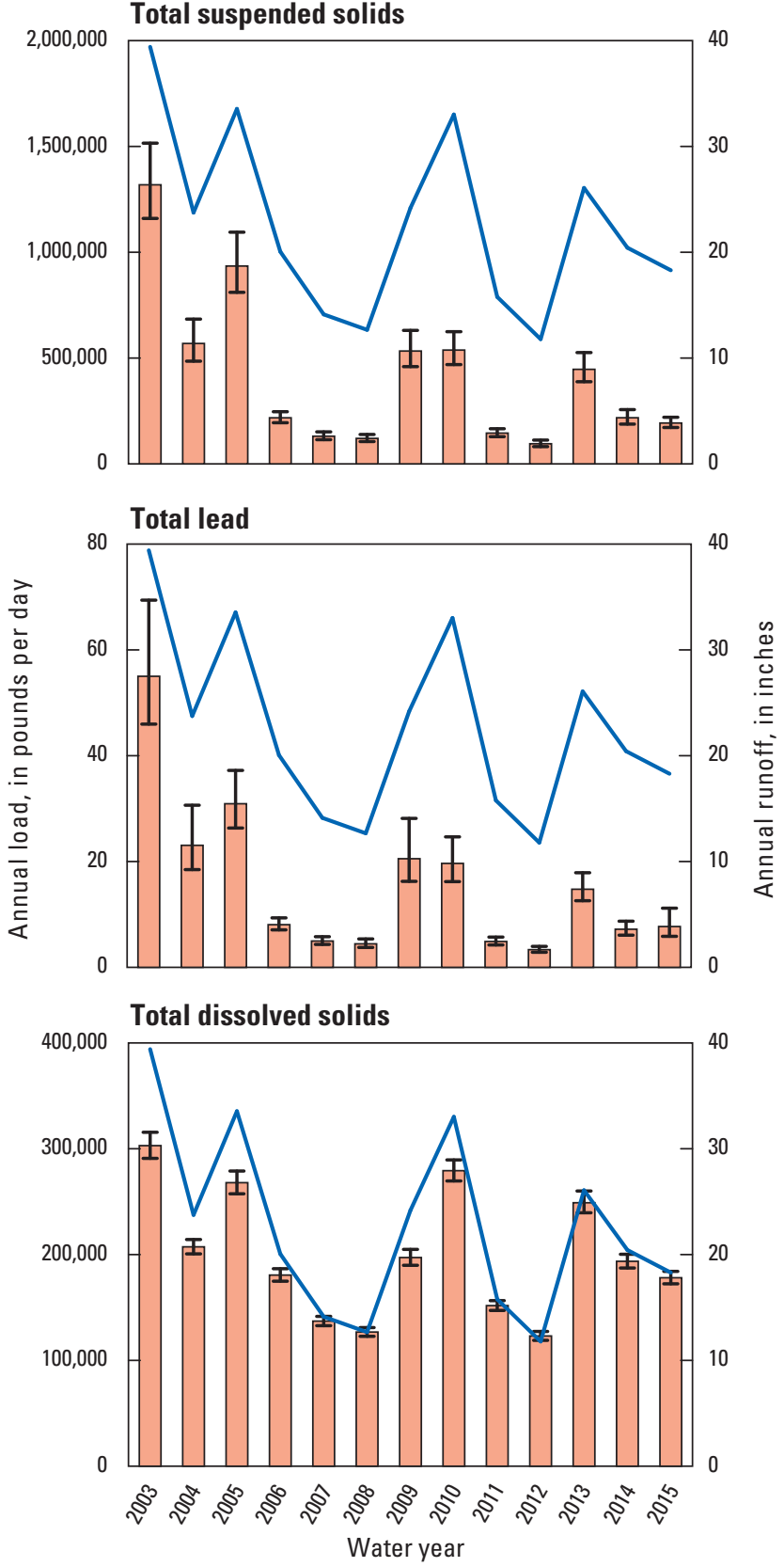

Suspended sediment

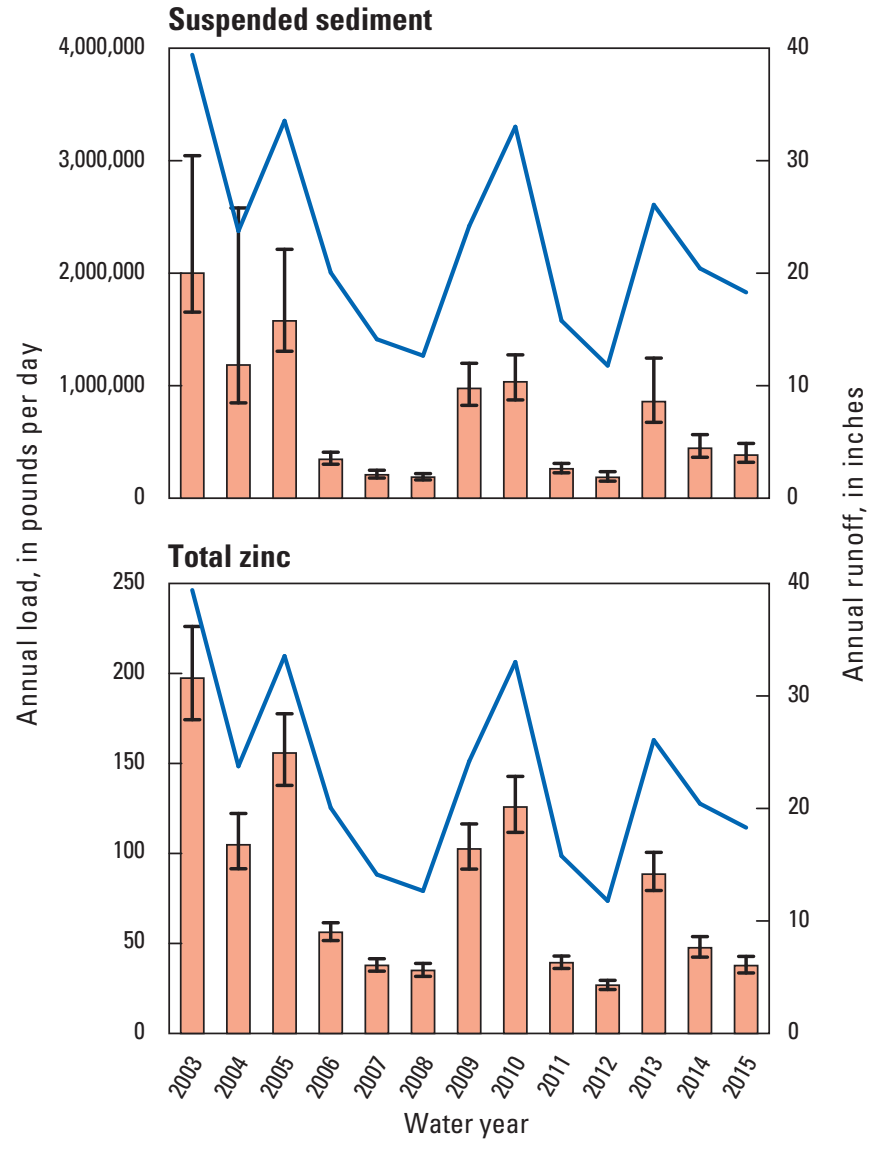

EXPLANATION

$\square$ Load

Confidence interval

工 Upper 95 percent

- Runoff

Figure 37. Annual loads and annual runoff for water years 2003-15 for the LTTM program study area in Gwinnett County, Georgia.-Continued 

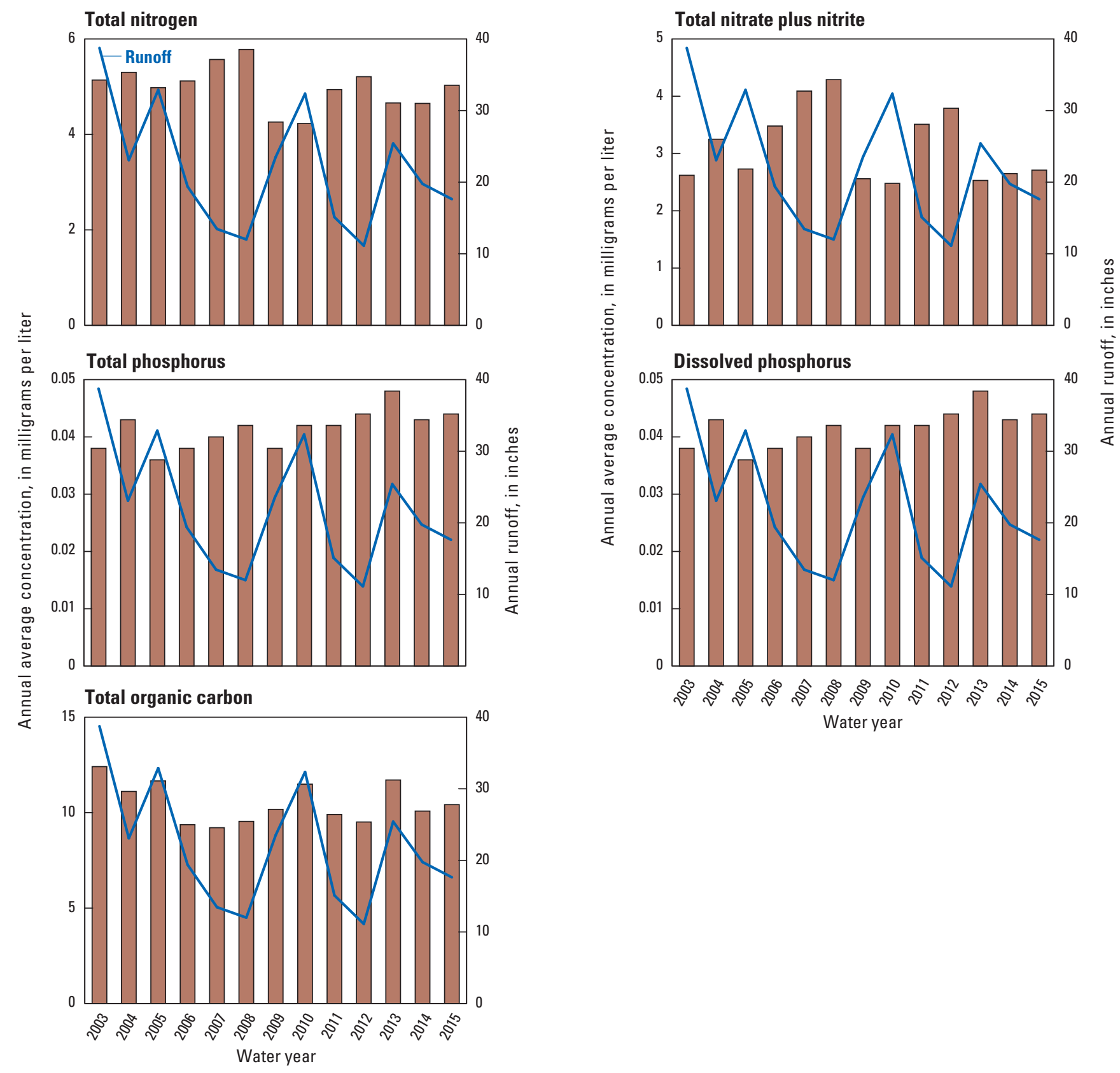

Figure 38. Annual average concentrations and annual runoff for water years 2003-15 for the LTTM program study area in Gwinnett County, Georgia. 

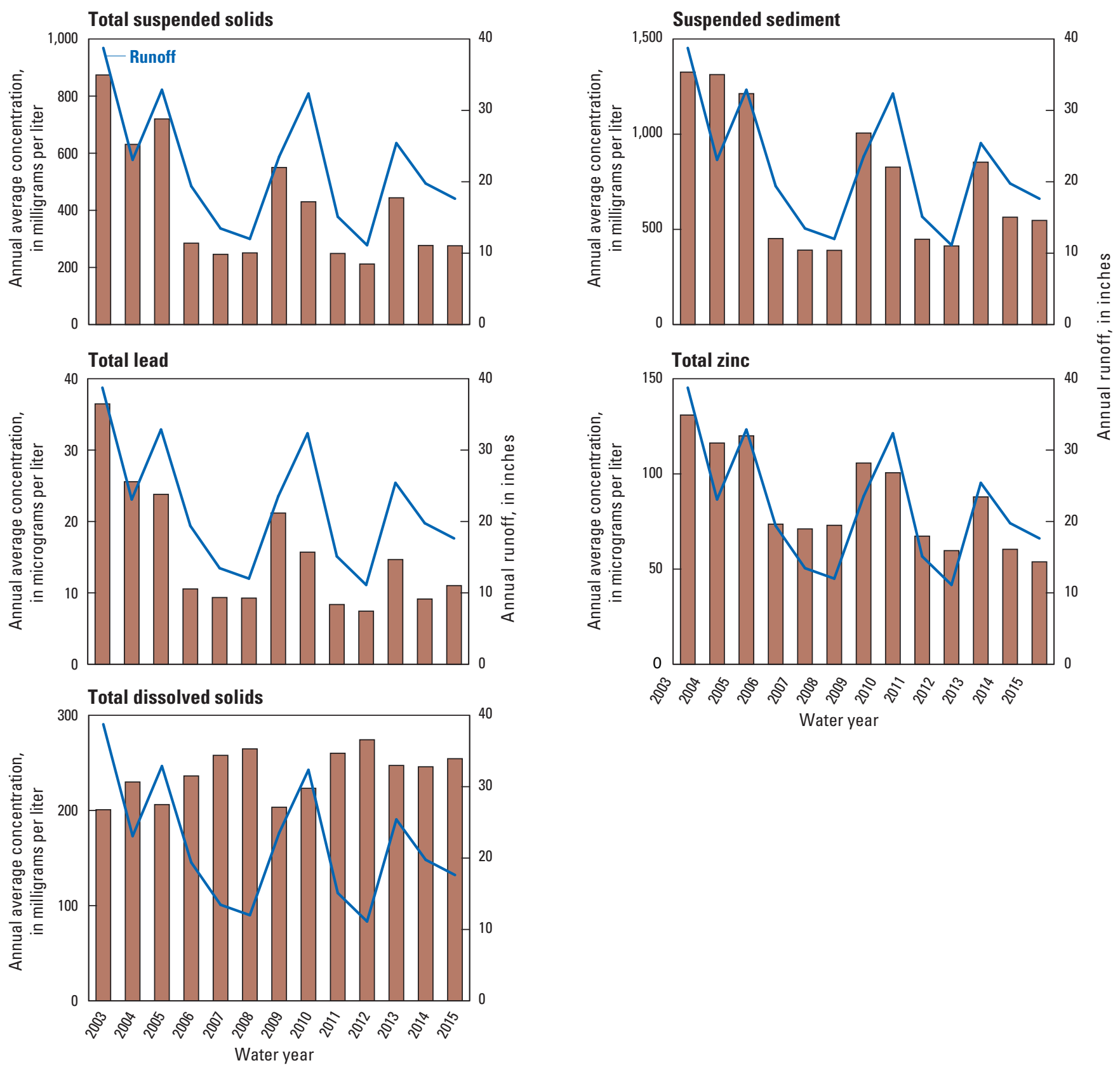

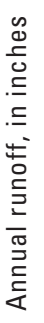

Figure 38. Annual average concentrations and annual runoff for water years 2003-15 for the LTTM program study area in Gwinnett County, Georgia.-Continued 
It is not unusual for a few of the largest storms in a year to transport the majority of the annual sediment load and is the result of the nearly two orders of magnitude increase in sediment concentrations between base flow and average stormflow observed at the 13 watersheds (fig. $26 I$ and $26 J$ ). During years with wet climatic conditions, runoff within the LTTM program study area was 61.5 percent higher than during years with an average climatic condition, while average TSS and SSC loads were 156 and 120 percent higher than average, respectively (fig. 39). Conversely, during drier years, little sediment may be transported. During years with dry climatic conditions, average annual runoff was 39.8 percent below average, while average TSS and SSC loads were 66.1 and 69.9 percent below average, respectively. There are fewer storms during drier years, and the storms tend to have low peak flows because base-flow discharges are also low, which then results in less sediment transported than might be expected on the basis of annual runoff alone.

Due to the strong relation between loads and runoff, trends in runoff can easily result in trends in loads, hence the reason for adopting the approach of identifying trends in concentrations herein where it is easy to remove the effect of variations in streamflow. Still, it is informative to examine trends in load to illustrate how these trends affect constituent transport. Annual runoff exhibited an overall decline during WYs 2003-15, the period for which loads were estimated, but the trend of this decline was not significant $(p$-value $=0.139$; table 12). Significant negative trends in loads were detected from linear trend lines fit between annual loads and time for 7 of the 10 constituents, all but DP, TOC, and TDS. These trends are readily discernable in the average annual concentration plots for TP, TSS, SSC, Pb, and Zn (figs. 29 and 32-35) because concentrations were lower later in the years with similar annual runoff. These trends in loads were fairly consistent with the trends identified in the load model residual concentrations for the larger watersheds. The insignificant decrease in runoff may still be having some effect on the load trends. Possible evidence of this effect includes many watersheds that had significantly positive trends in TOC and TDS residuals, while having negative, albeit insignificant, trends in loads.

The trend analysis indicated that TSS loads were decreasing by 57,000 pounds per day per year $(\mathrm{lb} / \mathrm{d} / \mathrm{yr})$ and SSC loads were decreasing by $87,000 \mathrm{lb} / \mathrm{d} / \mathrm{yr}$ over the 13 -year period. This decrease is substantial when considering that TSS loads averaged 420,000 lb/d and SSC loads 742,000 lb/d during this period.

\section{Watershed Yields}

Annual yields and confidence intervals for all 13 watersheds are compiled in Aulenbach and Joiner (2017; table 5, streamwater constituent yields). Average annual TN yields for WYs 2003-15 were highest for the North Fork Peachtree Creek and Yellow River watersheds (11.0 and 10.2 pounds per

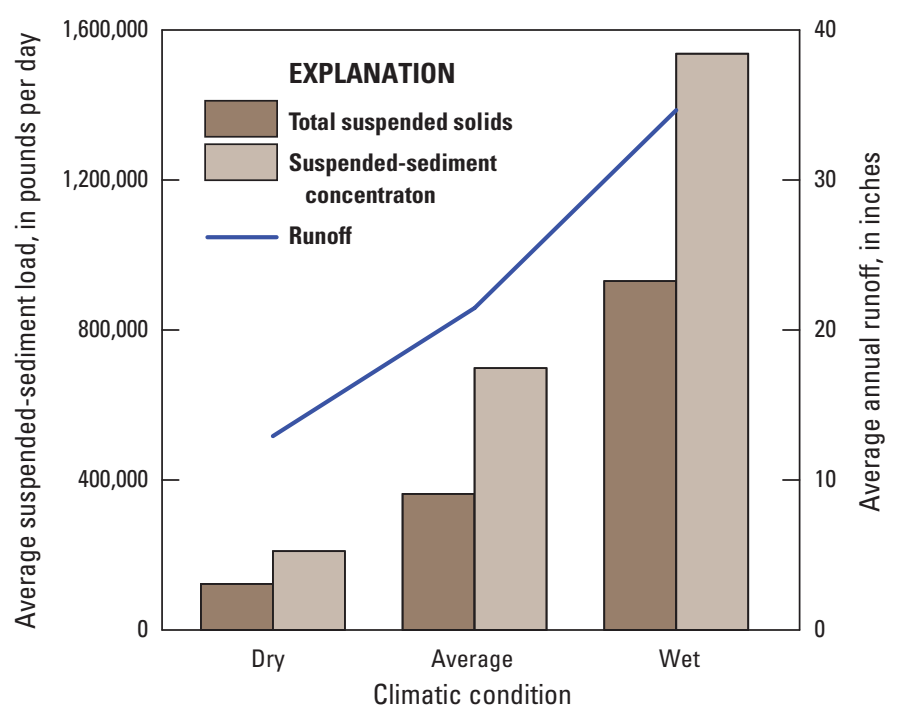

Figure 39. Average suspended-sediment loads and average annual runoff for years with dry (water years 2007, 2008, 2011, 2012), average (water years 2004, 2006, 2009, 2013-15), and wet (water years 2003, 2005, 2010) climatic conditions for water years 2003-15 for the LTTM program study area in Gwinnett County, Georgia.

acre per year (lb/acre/yr) as N, respectively; fig. 40). Average annual $\mathrm{NO}_{3}+\mathrm{NO}_{2}$ yields were highest for the Yellow River, Suwannee Creek, and North Fork Peachtree Creek watersheds $(6.36,3.96$, and $4.03 \mathrm{lb} / \mathrm{acre} / \mathrm{yr}$ as N). Yellow River and North Fork Peachtree Creek have the fourth and first highest percentages of impervious area (table 6; fig. 10). Sweetwater Creek, Brushy Fork Creek, Alcovy River, and Level Creek watersheds had the four lowest average annual TN and $\mathrm{NO}_{3}+\mathrm{NO}_{2}$ yields for the period. The Sweetwater Creek watershed, which is nested in the Yellow River watershed, had low nitrogen yields even though the Yellow River watershed had some of the highest nitrogen yields. This contrast illustrates how variable different parts of a larger watershed such as Yellow River can be. Overall, the $\mathrm{NO}_{3}+\mathrm{NO}_{2}$ fraction makes up 60.1 percent of TN loads.

Average annual TP and DP yields for WYs 2003-15 were highest for the North Fork Peachtree Creek watershed, 0.966 and $0.286 \mathrm{lb} /$ acre/yr as $\mathrm{P}$, respectively (fig. 41). Wheeler Creek, Richland Creek, Level Creek, and Crooked Creek watersheds also had higher TP and DP yields. The fact that these five watersheds had both higher TP and DP yields may indicate that TP and DP have similar sources, even though DP makes up a small portion of TP. Overall, the DP fraction makes up 18.9 percent of TP loads. High TP and DP yields appear to be related to high TSS yields, because these five watersheds also had the five highest average annual TSS yields. Richland Creek watershed had the highest basin slope of any of the 13 watersheds (fig. 5; table 5), while the Crooked Creek and North Fork Peachtree Creek watersheds had the two highest percentages of impervious area, 37.14 and 52.43 percent, respectively (fig. 10; table 6). 


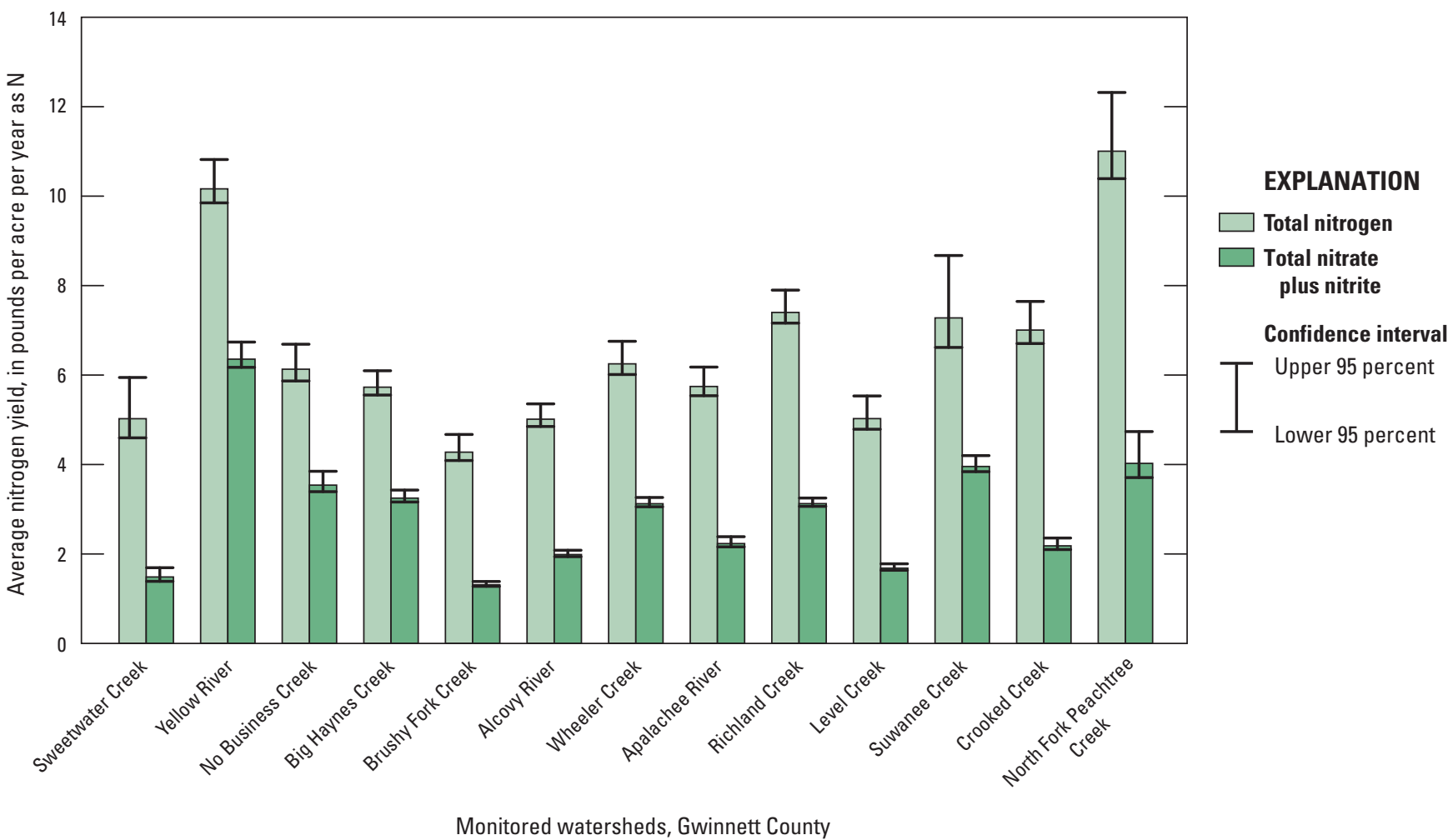

Figure 40. Average total nitrogen and total nitrate plus nitrite yields for 13 monitored watersheds in Gwinnett County, Georgia, for the period water years 2003-15. Sweetwater Creek watershed yields are for water years 2011-15.

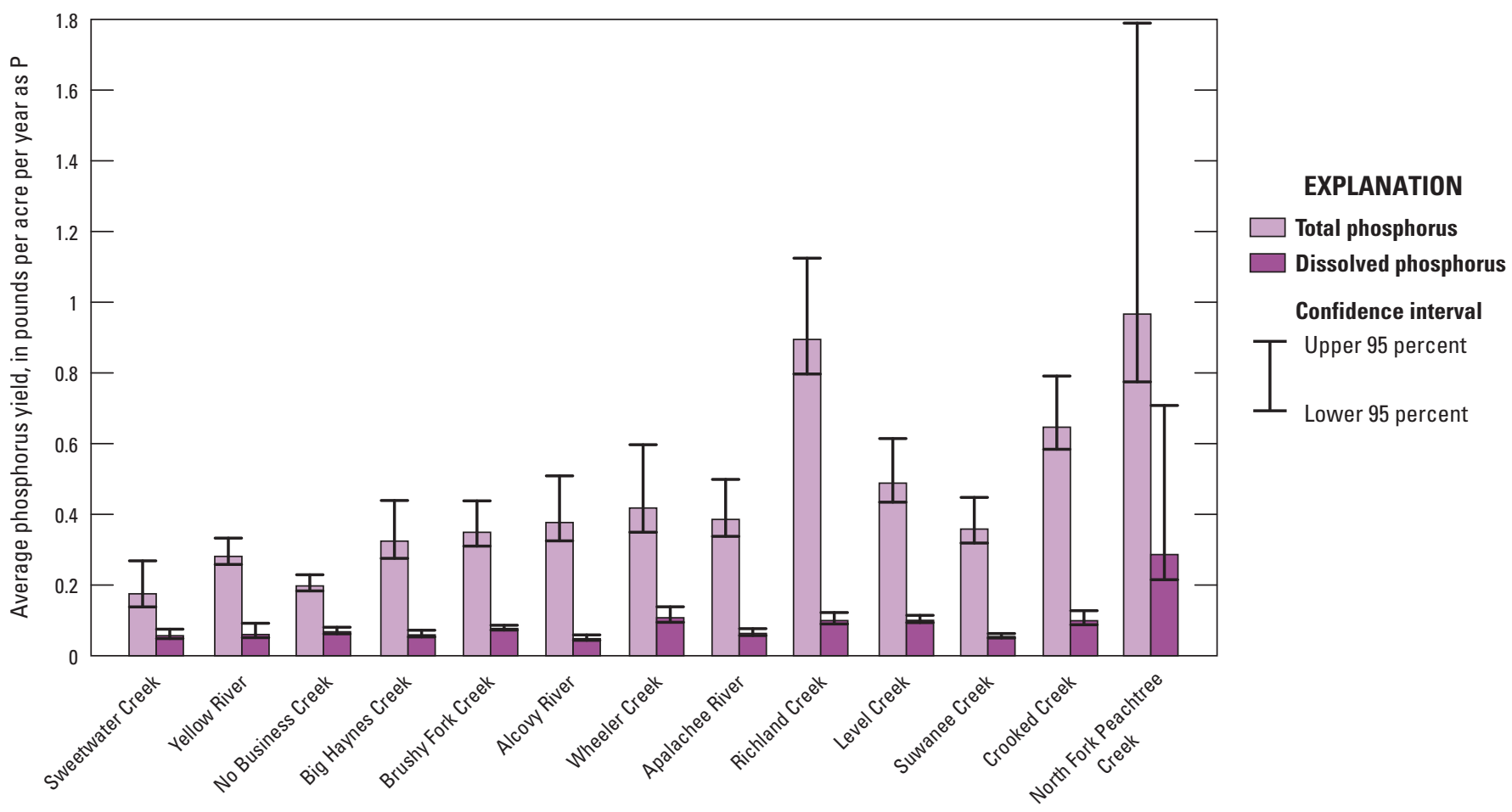

Monitored watersheds, Gwinnett County

Figure 41. Average total and dissolved phosphorus yields for 13 monitored watersheds in Gwinnett County, Georgia, for water years 2003-15. Sweetwater Creek watershed yields are for water years 2011-15. 
The Sweetwater Creek watershed had the lowest average annual TP yields ( $0.175 \mathrm{lb} / \mathrm{acre} / \mathrm{yr}$ as P) while the Alcovy River watershed had the lowest average annual DP yields (0.048 lb/acre/yr as P).

Average annual TOC yields for WYs 2003-15 were highest for Yellow River, Crooked Creek, and North Fork Peachtree Creek watersheds (18.9, 20.9 and 36.5 lb/acre/yr as carbon, respectively; fig. 42). These three watersheds had three of the four highest percentages of impervious area (fig. 5; table 5). The Alcovy River watershed has the lowest average annual TOC yield, $12.3 \mathrm{lb} / \mathrm{acre} / \mathrm{yr}$ as carbon. All the other watersheds had fairly similar TOC yields.

Average annual TSS yields for WYs 2003-15 were highest for the Richland Creek and Crooked Creek watersheds (2,720 and 1,790 lb/acre/yr, respectively; fig. 43). Richland Creek watershed had the highest basin slope (fig. 5; table 5), and Crooked Creek watershed had the second highest percentage of impervious area of the 13 watersheds (fig. 10; table 6). No Business Creek watershed had the lowest average annual TSS yield (434 lb/acre/yr) and had the fourth lowest percentage of high-density development (table 6).

Average annual SSC yields were highest for Apalachee River, Richland Creek, and Level Creek watersheds $(6,980,6,190$, and 4,410 lb/acre/yr, respectively) and lowest for the Suwanee Creek watershed (716 lb/acre/yr; fig. 43).
There was some inconsistency between which watersheds had the highest TSS versus SSC yields. Suspended-sediment concentration yields were notably higher than TSS yields. The ratio of SSC to TSS loads for all watersheds combined was about 1.77 , but this ratio varied widely by watershed: Suwanee Creek had the lowest ratio of 1.04, and Apalachee River had the highest ratio of 6.55. The watersheds with higher TSS and SSC yields generally had higher SSC to TSS ratios. Landers (2013) indicated that watersheds that have a higher percentage of sand-sized particles in stormflow runoff tend to have a greater discrepancy between SSC and TSS. The watersheds with the highest SSC yields had large confidence intervals, indicating that there was a lot of uncertainty in these estimates. Despite the differences between SSC and TSS, annual yields of TSS were used as the primary performance criterion for suspended sediment in the Gwinnett County Watershed Protection Plan (Gwinnett County Department of Public Utilities, 2000).

Average annual $\mathrm{Pb}$ yields for WYs 2003-15 were highest for Alcovy River and North Fork Peachtree Creek watersheds (0.073 and $0.069 \mathrm{lb} / \mathrm{acre} / \mathrm{yr}$, respectively), and average annual $\mathrm{Zn}$ yields were highest for North Fork Peachtree Creek, Crooked Creek, and Richland Creek watersheds (0.780, 0.395, and 0.291 lb/acre/yr, respectively, fig. 44). These three watersheds also had three of the four highest

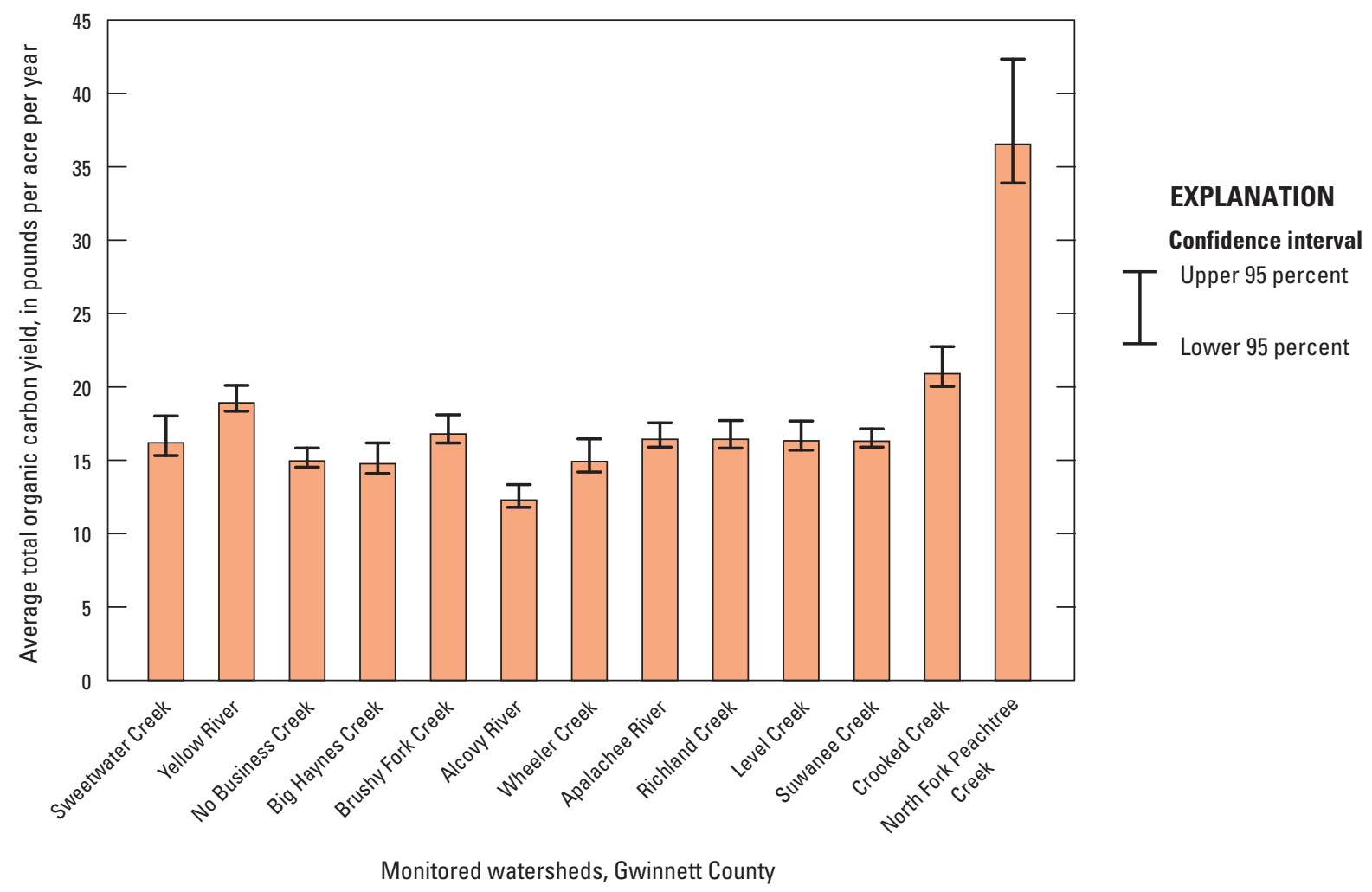

Figure 42. Average total organic carbon yields for 13 monitored watersheds in Gwinnett County, Georgia, for water years 2003-15. Sweetwater Creek watershed yields are for water years 2011-15. 


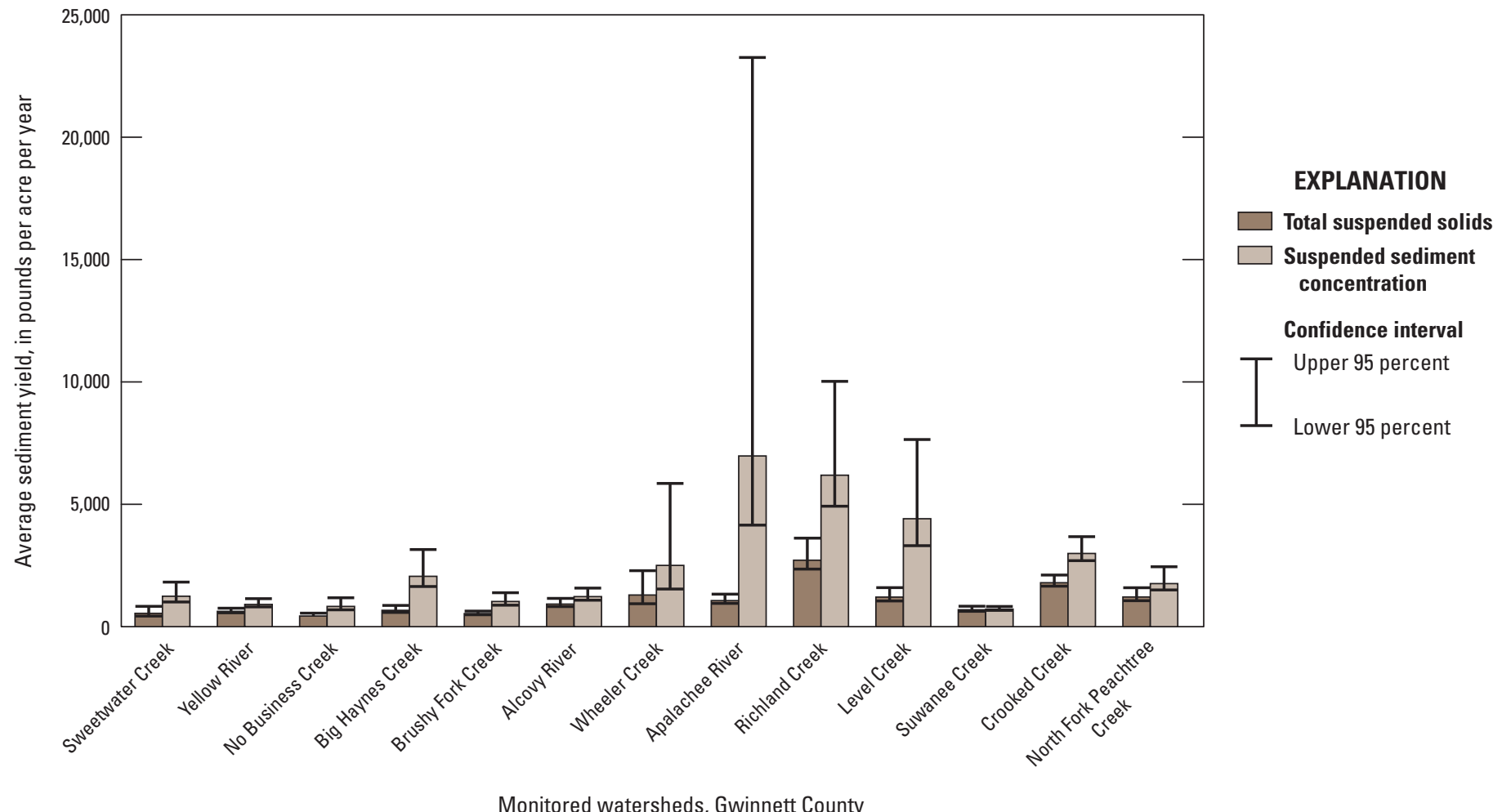

Figure 43. Average total suspended solids and suspended-sediment yields for 13 monitored watersheds in Gwinnett County, Georgia, for water years 2003-15. Sweetwater Creek watershed yields are for water years 2011-15.

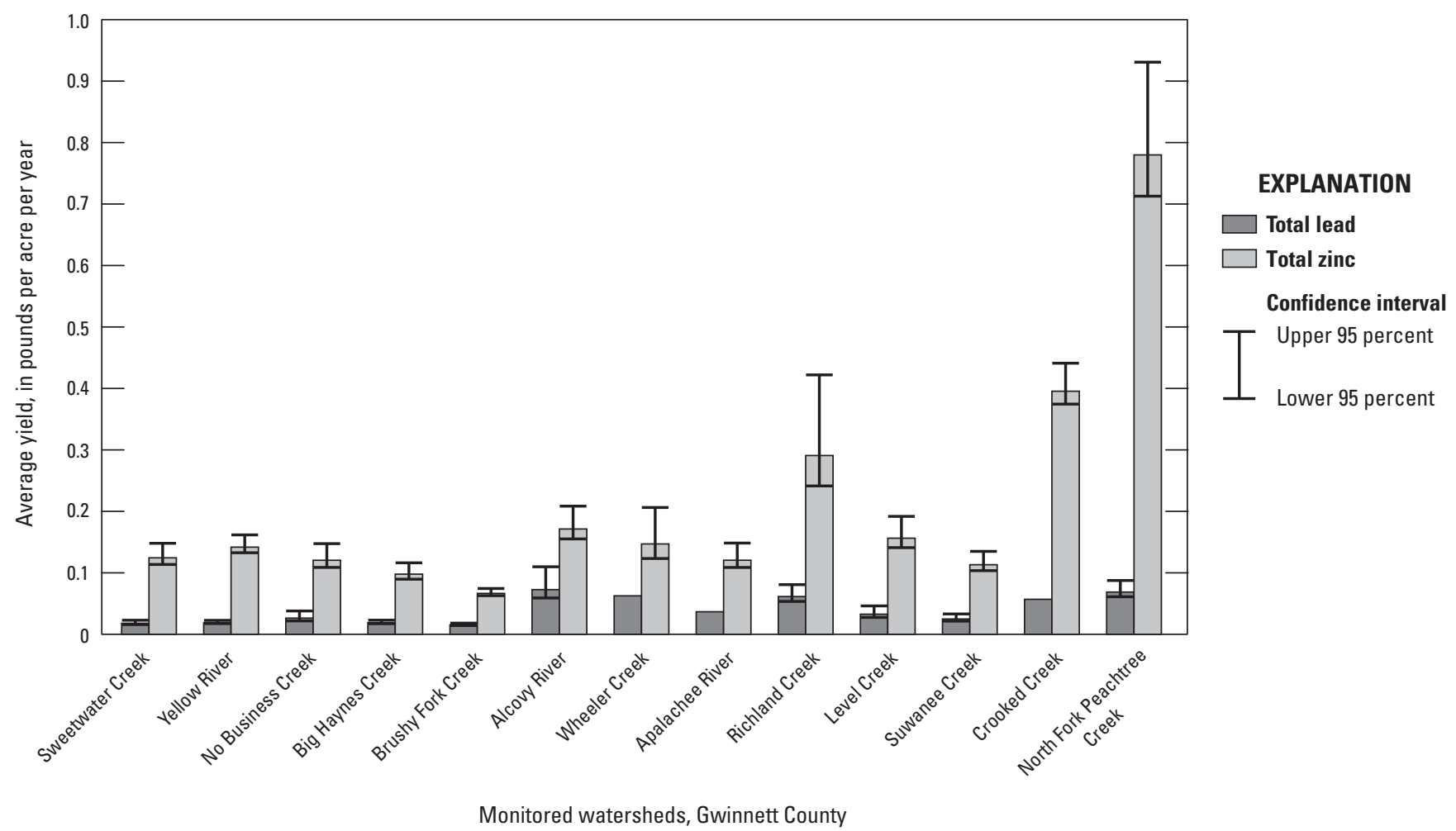

Figure 44. Average total lead and total zinc yields for 13 monitored watersheds in Gwinnett County, Georgia, for water years 2003-15. Sweetwater Creek watershed yields are for water years 2011-15. 
average annual TSS yields. Richland Creek watershed had the highest basin slope of any of the 13 watersheds (fig. 5; table 5), whereas Crooked Creek and North Fork Peachtree Creek had the two highest percentages of impervious area (fig. 10; table 6). The Brushy Fork Creek watershed had the lowest average annual $\mathrm{Pb}$ and $\mathrm{Zn}$ yields of 0.015 and $0.067 \mathrm{lb} / \mathrm{acre} / \mathrm{yr}$, respectively. The Brushy Fork watershed had the lowest mean basin slope, the second lowest percentage of impervious area, and the second lowest average annual TSS yields.

Average annual TDS yields for WYs 2003-15 were highest for North Fork Peachtree Creek and Yellow River watersheds (791 and $433 \mathrm{lb} / \mathrm{acre} / \mathrm{yr}$, respectively; fig. 45). North Fork Peachtree Creek and Yellow River watersheds had the first and fourth highest percentages of impervious area, respectively (fig. 10; table 6). Brushy Fork Creek watershed had the lowest average annual TDS yield of $196 \mathrm{lb} / \mathrm{acre} / \mathrm{yr}$ and had the lowest mean basin slope (fig. 5; table 5) and the second lowest percentage of impervious area.

\section{Differences with Previous Load Estimates}

Loads are estimated in this report for WYs 2003-15.

These loads are different than the loads estimated for WYs 2004-09 in Joiner and others (2014) for several reasons.
The calibration dataset used to fit the load estimation models in this report represented samples from WYs 2001-15, whereas the previous report used samples from WYs 1996-11. These periods likely had different average concentration responses. The load estimation regression models (eq. 2) were improved by including a term for base-flow discharge and a term to allow for a separate slope for discharge during base-flow conditions.

\section{Uncertainty in Load Estimates}

Confidence intervals for load estimates are provided for all annual loads. Errors are estimated on the basis of how well the load estimation regression model fits the observed data applied to the conditions observed during the estimation period. These confidence intervals are useful for determining whether differences between loads are meaningful and for assessing the magnitude of change that can be detected as a trend. Still, confidence intervals should be used as a guide, knowing errors could be larger, as there can be quite a bit of uncertainty in estimating errors.

The sources of error in the load estimation process can be numerous. Measurement errors include stream stage, the stage-discharge relation, the representativeness of the water-quality sampling, and the laboratory analytical analyses.

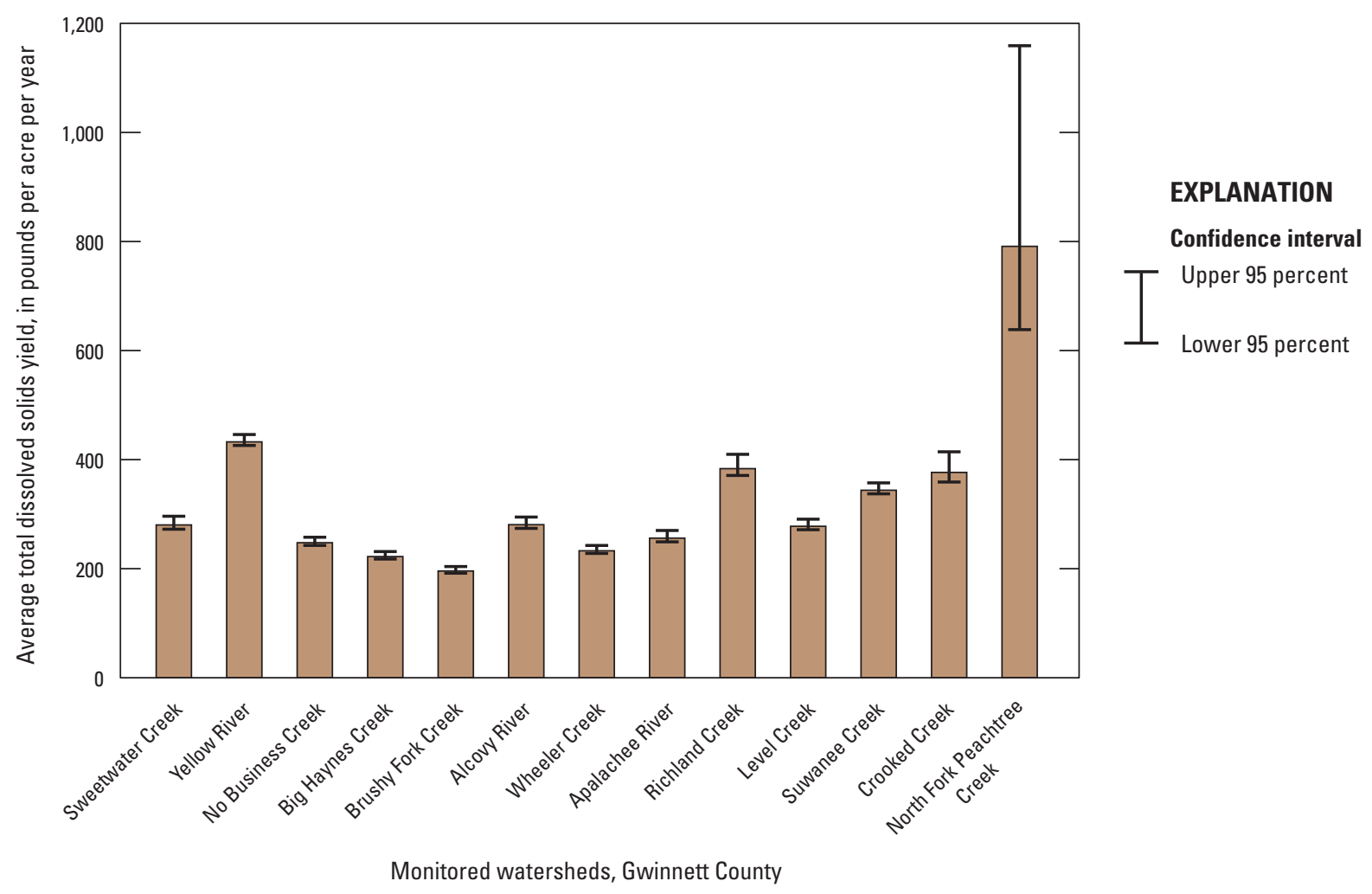

Figure 45. Average total dissolved solids yields for 13 monitored watersheds in Gwinnett County, Georgia, for water years 2003-15. Sweetwater Creek watershed yields are for water years 2011-15. 
The precision of these measurements results in model uncertainty, which is then incorporated into the errors estimated by the load models. Still, biases in any of these measurements would result in biases in the load estimates. The regressionmodel approach uses the inherent assumption that the variability in the model relations are due to errors in the predicted variables and that there are no errors in the explanatory variables. It is not possible for the regression model to accurately predict the confidence intervals for conditions observed in the estimation period that are not included in the calibration dataset. The calibration datasets used to model loads herein were sufficiently large that they represented the full range of flow conditions observed across all seasons. Although care was taken to ensure that the models were of sufficient quality such that residuals were identically distributed, any residual patterns could result in biases over particular ranges of flow or turbidity. Error estimates assume that deviations from the model are temporally random, but serial correlations are common, resulting in errors to be underestimated at shorter reporting periods (Aulenbach, 2013). The use of turbidity as a surrogate for many of the constituents may effectively remove serial correlation and alleviate its effects on error estimates for these models.

Load estimation errors were also introduced with the application of estimating loads on a time-step basis, which was a necessary accommodation to estimate loads from storm composite samples. Although the purpose of the time step was to capture the average storm streamflow (and turbidity) for which the storm composite samples are represented, the time step does not always function properly. Time-step average streamflows during storms can be lower than average event streamflows represented by storm composite samples due to (1) the time step splitting a single storm into two time periods, depending on the timing of the storm, and (2) storms having a duration shorter that the time step, thereby including adjacent base-flow streamflows. Time-step average streamflows that are higher than average event streamflows can likewise result if a storm with a duration greater than the length of the time step was split such that the time step represented the peak of the event. These differences in streamflows are important when the relation between concentration and discharge is not near linear, as the load estimates would be different depending on how the averages in the time steps compare to the observed average storm discharge. As the concentration-discharge relations were fit in logarithmic space, the fit is generally not linear, and models that contain the flow-squared term are likely to be more nonlinear. The effect of splitting events by time steps on load estimation is likely dependent on the particular model relations, and possible effects of this relation have not been fully assessed at this time. Despite this issue, the approach was superior to applying storm composite sample average concentrations to instantaneous discharges.

\section{Interpreting Aggregate Effects on Water Quality}

The water quality of streams in a watershed reflects and integrates the effects of watershed characteristics, hydrologic processes and variability, biogeochemical processes, and human influences. Although watershed characteristics including land use can indicate possible explanations for variations in water quality among watersheds, relations rarely reflect straightforward cause and effect. In some cases, there can be spurious relations where two unrelated variables appear related due to some other common response variable. For example, BMP implementation and constituent inputs could both be increasing in watersheds with higher development rates. Several factors can result in similar water-quality patterns; for example, in this study high impervious area and steep basin slope both appear to be related to greater transport and higher yields of TSS and SSC. A specific watershed characteristic may not always relate to a particular water-quality pattern in all cases because water quality is integrating all the processes within the watershed; for example, in this study the watersheds with the lowest $\mathrm{Zn}$ yields also had low percentages of high-density development, yet not all the watersheds with low percentages of high-density development had low $\mathrm{Zn}$ yields. There may be specific, unaccounted for human activities present within individual watersheds that result in point-source pollutants that affect water-quality constituents. Many watershed characteristics are also related to each other, whereas individual characteristics may be better at explaining particular relations in water quality. For example, the percentage area of high-density development and impervious area are correlated with each other, but high-density development may be more related to specific trace elements that might be the result of pollutants, while impervious area may be more related to the transport of TSS and SCC. Furthermore, Gwinnett County has long required BMPs to control and mitigate the effects of increases in impervious areas. The effectiveness of these measures is difficult to parse out because more BMPs are implemented in watersheds that have higher percentages of impervious area.

The effects of variations in climate can have large effects on water-quality concentrations, loads, and yields. These effects occur for any water-quality constituent that exhibits concentration variations with discharge or season, because climatic variations in the amount and distribution of runoff annually and seasonally will affect the concentrations observed. This is especially notable for constituents that are transported during storms that exhibit a strong relation of increasing concentration with discharge, such as sediment (TSS and SSC) and other sediment-related constituents (TP, Zn, and Pb). Dry years have less runoff (lower average 
annual discharges) with generally smaller hydrologic responses to storms (due to reduced base flow), which result in less opportunity for storm transport. Similarly, wet years have more runoff and greater hydrologic responses to storms, resulting in more transport. For constituents that exhibit dilution at higher discharge- $-\mathrm{TN}, \mathrm{NO}_{3}+\mathrm{NO}_{2}$, and TDS - annual average concentrations will be higher in dry years and lower in wet years (fig. 38). Although the amount of annual runoff is often the most important controlling factor determining the magnitude of annual loads, variations in concentrations related to variations in discharge can be as or more important, as observed for suspended-sediment loads for the LTTM program study area (fig. 39). Increases in average TSS and SSC loads between average and wet climatic conditions were 154 and 95 percent more than the percentage increase observed in runoff, respectively. Similarly, decreases in average TSS and SSC loads between average and dry climate conditions were 66 and 76 percent more than the percentage decrease observed in runoff, respectively. Removing the effects of climate can be further complicated if the concentration-discharge relation is altered by the climatic conditions. For example, some constituents can be retained during droughts and flushed when conditions return to average. It can be difficult to determine whether a change in the concentration-discharge relation over time is the result of climatic variability or human activity. Nevertheless, patterns in model residual concentrations (figs. 27-36) did not appear to vary with the multiple climatic cycles observed during this study period (fig. 16).

\section{Summary}

The U.S. Geological Survey (USGS), in cooperation with Gwinnett County Department of Water Resources, established a comprehensive Long-Term Trend Monitoring (LTTM) program in 1996 to monitor, analyze, and quantify the magnitudes of pollutants and the effects of urbanization on six watersheds. In 2001, six additional watersheds were added to the LTTM program. A thirteenth watershed was added in 2010. These 13 watersheds were continuously monitored for water level (stage), discharge, precipitation, and water-quality properties (water temperature, specific conductance [SC], and turbidity). For each season, summer (May-October) and winter (November-April), three stormcomposited samples were collected during storm events, and one sample was collected during base-flow conditions for a total of eight samples per year. Samples were analyzed for $\mathrm{SC}$, turbidity, nutrients (total nitrate plus nitrite $\left[\mathrm{NO}_{3}+\mathrm{NO}_{2}\right]$, total ammonia plus organic nitrogen [TKN], total phosphorus [TP], dissolved phosphorus [DP], and total organic carbon [TOC]), suspended sediment (total suspended solids [TSS] and suspended-sediment concentration [SSC]), trace metals (total lead $[\mathrm{Pb}]$ and total zinc $[\mathrm{Zn}]$ ), and total dissolved solids (TDS). The sampling scheme was designed to identify variations in water quality both hydrologically and seasonally.

Gwinnett County, an urban county of the Atlanta metropolitan area, is composed predominantly of headwater watersheds along the Eastern Continental Divide. Watershed mean basin slopes range from 7.4 to 16.7 percent. Gwinnett County has undergone rapid population growth from about 1980 to 2015, though growth had slowed somewhat during 2008-11. Land use has become more highly developed over time. Land use is summarized for each watershed for 2012. The percentage of impervious area has a large influence on hydrology and water quality. Changes in the percentage of impervious area are documented for 2000-14, with increases of varying extent observed within most watersheds.

Gwinnett County has a humid, subtropical climate with a mean annual precipitation of 54.7 inches and high evapotranspiration rates during the growing season. Several droughts occurred during the study period - water years (WY) 2002, 2007-08, and 2011-12. Study area runoff ratios, the percentage of precipitation that occurs as runoff, ranged from 28.4 to 55.1 percent for WYs 2002-15, with lower runoff ratios in low precipitation years. The watersheds with the highest percentage of impervious areas had the highest runoff ratios. Watershed base-flow indexes, the ratio of base-flow runoff to total runoff, were inversely correlated with watershed impervious area.

Selected flood-frequency statistics were calculated for 13 streamgages in the study area that have 10 or more years of annual peak flow data through WY 2015. Low-outlier and historic information were incorporated into the floodfrequency analysis. A Kendall's tau nonparametric test indicated that none of these streamgages exhibited a significant trend in the annual peak flow data. A comparison of base-flow and stormflow water quality indicate that turbidity, TKN, total nitrogen (TN), TP, TOC, TSS, SSC, Pb, and Zn concentrations increased with increasing discharge at all watersheds. Specific conductance decreased during stormflow at all watersheds, and TDS exhibited dilution at a few of the watersheds. Total suspended solids and SSC typically were two orders of magnitude higher in stormflow samples than in base-flow samples, turbidities were about 1.5 orders of magnitude higher, TP and $\mathrm{Zn}$ were about one order of magnitude higher, and TKN, TN, $\mathrm{TOC}$, and $\mathrm{Pb}$ were about twofold higher.

Seasonality and long-term trends were determined for 10 constituents (TN, $\mathrm{NO}_{3}+\mathrm{NO}_{2}, \mathrm{TP}, \mathrm{DP}, \mathrm{TOC}, \mathrm{TSS}, \mathrm{SSC}$, $\mathrm{Pb}, \mathrm{Zn}$, and TDS) for WYs 2001-15. Seasonal terms were significant in most load estimation models for TOC, TSS, $\mathrm{SSC}, \mathrm{Pb}$, and $\mathrm{Zn}$, and in slightly more than half of the models for $\mathrm{TN}, \mathrm{NO}_{3}+\mathrm{NO}_{2}$, TP, and DP. Seasonal patterns for these constituents were all fairly similar, with higher concentrations in the summer and lower concentrations in the winter. A linear long-term trend analysis of residual concentrations from the 
flow-only load estimation model (without time-trend terms) identified significant trends in 67 of the 130 constituentwatershed combinations. Seventy percent of the significant trends were negative. Constituents exhibiting predominantly positive trends included TOC (5 watersheds) and TDS (9 of the 10 trends were positive). Constituents exhibiting only negative trends included TP (10 watersheds), TSS ( 9 watersheds), SSC ( 7 watersheds), Pb (8 watersheds), and Zn (5 watersheds). The other constituents exhibited fewer trends, both positive and negative: TN (1 positive, 2 negative), $\mathrm{NO}_{3}+\mathrm{NO}_{2}$ ( 2 positive, 4 negative), and DP (3 positive, 1 negative). Of the five watersheds that exhibited large increases in impervious areas during WYs 2000-14 (Sweetwater Creek, Yellow River, Alcovy Creek, Wheeler Creek, and Apalachee River), Yellow River had a negative trend in TSS while Alcovy Creek and Wheeler Creek had negative trends in TSS and SSC. The fact that transport of suspended sediment is either remaining the same or declining at the watersheds that are experiencing the highest increases in impervious areas suggests that the implementation of best management practices (BMP) within these watersheds during this period is maintaining (within the ability to detect trends) and, in some cases, improving water quality.

Streamwater constituent loads were estimated for 10 water-quality constituents for the 13 -year period WYs 2003-15. These estimates represent the cumulative effects of watershed characteristics, hydrologic processes and variability, biogeochemical processes, and human influences on watershed water quality. Yields, in load per unit area, were used to compare loads from watersheds with different sizes. For the Gwinnett County LTTM program, storm samples were collected as a composite so the load estimation approach developed and used for the Gwinnett County LTTM program for 1998-2003 was adopted with some minor modifications. This approach employs the commonly used regression-model method, but employs a time-step estimation approach to simulate storm average discharges and allows for separate relations for base-flow and storm-based average concentrations versus discharge and turbidity model terms.

Although the amount of annual runoff was the primary factor in variations in annual loads, changes in constituent average annual concentrations that were related to climatic conditions were also important. This was especially evident for TSS and SSC loads in which increases in loads were attributed about equally to increases in concentration and runoff during wet years. Significant negative trends in loads were detected from linear trend lines fit between annual loads and time for 7 of the 10 constituents - TN, $\mathrm{NO}_{3}+\mathrm{NO}_{2}, \mathrm{TP}$, TSS, SSC, $\mathrm{Pb}$, and $\mathrm{Zn}$. The trend analysis indicated that TSS and SSC loads were decreasing by a rate of 57,000 and 87,000 pounds per day per year, respectively, which is substantial when considering that TSS and SSC loads averaged 420,000 and 742,000 pounds per day, respectively, during this same period.

Variations in constituent yields between watersheds appeared to be related to various watershed characteristics though relations rarely reflect straightforward cause and effect. Suspended sediment (TSS and SSC) along with constituents transported predominately in solid phase (TP, TOC, Pb, and $\mathrm{Zn}$ ), and TDS typically had higher yields from watersheds that had high percentages of impervious areas (Yellow River, Crooked Creek, and North Fork Peachtree Creek) or high basin slope (Richland Creek) than other watersheds. High TN yields, which have a significant dissolved component, were also associated with watersheds with high percentages of impervious areas. High percentages of impervious area results in increased runoff, flood magnitudes, and the "flashiness" of flooding (how rapidly streamflow responds to rainfall), which can result in increased land-surface erosion and stream transport of sediments. Low TN, TSS, $\mathrm{Pb}$, and $\mathrm{Zn}$ yields appear to be associated with watersheds that have a low percentage of high-density development, but this characteristic did not presuppose high yields. Watershed $\mathrm{Pb}$ and $\mathrm{Zn}$ yields were related to TSS yields. Total suspended solids and SSC yields differed, which is possibly the result of low-biased TSS concentrations for samples with sand fractions of greater than 25 percent.

Long-term, comprehensive records of climatic, hydrologic, and water-quality conditions can be used by watershed managers to evaluate, protect, and enhance rivers and streams. The monitoring stations used in this study represent a range of watershed conditions, including water-quality attainment status, point-source discharges, and other physical characteristics. The computation and analysis of constituent loads is a critical element and useful tool in the management and protection of the diverse watersheds in Gwinnett County, Georgia. The annual load of total suspended solids has been identified in the Gwinnett County Watershed Protection Plan as a target performance criterion. The Gwinnett County Department of Water Resources uses these computations along with the assessment of trends in imperviousness for the management and protection of aquatic habitat. 


\section{References Cited}

American Public Health Association, American Water Works Association, and Water Pollution Control Federation, 1995, Standard methods for the examination of water and wastewater (19th ed.): Washington, D.C., American Public Health Association, variously paged.

American Society for Testing and Materials (ASTM), 2000, Standard test methods for determining sediment concentration in water samples: D3977-97, v. 11.02 Water (II), p. 395-400.

Atlanta Regional Commission, 2012, 2012 Land use GIS dataset: Atlanta Regional Commission web page, accessed January 18, 2017, at http://www.atlantaregional.com/infocenter/gis-data-maps/gis-data.

Aulenbach, B.T., 2013, Improving regression-model-based streamwater constituent load estimates derived from serially correlated data: Journal of Hydrology, v. 503, p. 55-66.

Aulenbach, B.T., Burns, D.A., Shanley, J.B., Yanai, R.D., Bae, Kikang, Wild, A.D., Yang, Yang, and Yi, Dong, 2016, Approaches to stream solute load estimation for solutes with varying dynamics from five diverse small watersheds: Ecosphere, v. 7, no. 6, 22 p.

Aulenbach, B.T., Buxton, H.T., Battaglin, W.A., and Coupe, R.H., 2007, Streamflow and nutrient fluxes of the MississippiAtchafalaya River Basin and subbasins for the period of record through 2005: U.S. Geological Survey Open-File Report 2007-1080, accessed January 17, 2017, at https://pubs.usgs.gov/of/2007/1080/.

Aulenbach, B.T., and Joiner, J.K., 2017, Stream water-quality summary statistics and outliers, streamwater load models and yield estimates, and peak flow modeling parameters for 13 watersheds in Gwinnett County, Georgia: U.S. Geological Survey data release, https://doi.org/10.5066/F7639MXG.

Bornstein, Robert, and Lin, Qinglu, 2000, Urban heat islands and summertime convective thunderstorms in AtlantaThree case studies: Atmospheric Environment, v. 34, no. 3, p. 507-516.

Calhoun, D.L., Frick, E.A., and Buell, G.R., 2003, Effects of urban development on nutrient loads and streamflow, Upper Chattahoochee River Basin, Georgia, 1976-2001: Proceedings of the 2003 Georgia Water Resources Conference, held April 23-24, 2003, at the University of Georgia, Kathyrn J. Hatcher, editor, Institute of Ecology, The Univerisity of Georgia, Athens, Georgia.

Childress, C.J.O., Foreman, W.T., Connor, B.F., and Maloney, T.J., 1999, New reporting procedures based on long-term method detection levels and some considerations for interpretations of water-quality data provided by the U.S. Geological Survey National Water Quality Laboratory: U.S. Geological Survey Open-File Report 99-193, 19 p.
Cohn, T.A., Caulder, D.L., Gilroy, E.J., Zynjuk, L.D., and Summers, R.M., 1992, The validity of a simple statistical model for estimating fluvial constituent loads-An empirical study involving nutrient loads entering Chesapeake Bay: Water Resources Research, v. 28, no. 9, p. 2353-2363.

Cohn, T.A., DeLong, L.L., Gilroy, E.J., Hirsch, R.M., and Wells, D.K., 1989, Estimating constituent loads: Water Resources Research, v. 25, no. 5, p. 937-942.

Cohn, T.A., England, J.F., Berenbrock, C.E., Mason, R.R., Stedinger, J.R., and Lamontagne, J.R., 2013, A generalized Grubbs-Beck test for detecting multiple potentially influential low outliers in flood series: Water Resources Research, v. 49 , no. 8 , p. 5047-5058.

Cohn, T.A., Lane, W.L., and Baier, W.G., 1997, An algorithm for computing moments-based flood quantile estimates when historical flood information is available: Water Resources Research, v. 33, no. 9, p. 2089-2096.

Crawford, C.G., 1991, Estimation of suspended-sediment rating curves and mean suspended-sediment loads: Journal of Hydrology, v. 129, p. 331-348.

Dann, M.S., Lynch, J.A., and Corbett, E.S., 1986, Comparison of methods for estimating sulfate export from a forested watershed: Journal of Environmental Quality, v. 15, no. 2, p. 140-145.

DeGasperi, C.L., Berge, H.B., Whiting, K.R., Burkey, J.J., Cassin, J.L., and Fuerstenberg, R.R., 2009, Linking hydrologic alteration to biological impairment in urbanizing streams of the Puget Lowland, Washington, USA: Journal of the American Water Resources Association, v. 45, no. 2, p. 512-533.

Dixon, P.G., and Mote, T.L., 2003, Patterns and causes of Atlanta's urban heat island-Initiated precipitation: Journal of Applied Meteorology and Climatology, v. 42, p. 1273-1284, accessed February 3, 2017, at https://doi.org/ 10.1175/1520-0450(2003)042<1273:PACOAU>2.0.CO;2.

Feaster, T.D., Gotvald, A.J., and Weaver, J.C., 2014, Methods for estimating the magnitude and frequency of floods for urban and small, rural streams in Georgia, South Carolina, and North Carolina, 2011: U.S. Geological Survey Scientific Investigations Report 2014-5030, 104 p., accessed January 17, 2017, at https://pubs.usgs.gov/sir/2014/5030/.

Ferguson, R.I., 1986, River loads underestimated by rating curves: Water Resources Research: v. 22, no. 1, p. 74-76.

Gotvald, A.J., 2010, Surface-water quality-assurance plan for the U.S. Geological Survey Georgia Water Science Center, 2010: U.S. Geological Survey Open-File Report 2010-1263, 43 p.

Gray, J.R., Glysson, G.D., Turcios, L.M., and Schwarz, G.E., 2000, Comparability of suspended-sediment concentration and total suspended solids data: U.S. Geological Survey Water-Resources Report 2000-4191, 20 p. 
Gwinnett County Department of Planning and Development, 2006, Gwinnett County, Georgia, Stormwater systems and facilities installation standards and specifications: Gwinnett County, Georgia, last revised July 28, 2006, accessed May 31, 2016, at https://www.gwinnettcounty.com/static/ departments/planning/pdf/stormwater_review_stormwater_systems_design_manual.pdf.

Gwinnett County Department of Public Utilities, 2000, Gwinnett County watershed protection plan: Atlanta, Ga., CH2MHill, prepared in June 2000 for Gwinnett County, Georgia, 52 p., accessed May 31, 2016, at http://www. gwinnettcounty.com/static/departments/publicutilities/ pdf/Gwinnett-WPP.pdf.

Gwinnett County, Georgia, 2004, State of the county 04 Gwinnett County: Gwinnett County, 4 p., accessed January 31, 2014, at http://www.gwinnettcounty.com/ static/departments/boc/pdf/2004_state_county.pdf.

Gwinnett County, Georgia, 2005, State of the county 05 Gwinnett County: Gwinnett County, 4 p., accessed January 31, 2014, at http://www.gwinnettcounty.com/ static/departments/boc/pdf/2005_state_county.pdf.

Gwinnett County, Georgia, 2006, State of the county 06 Gwinnett County: Gwinnett County, 4 p., accessed January 31, 2014, at http://www.gwinnettcounty.com/ static/departments/boc/pdf/2006_SOC.pdf.

Gwinnett County, Georgia, 2007, 07 state of the county: Gwinnett County, 4 p., accessed January 31, 2014, at http://www.gwinnettcounty.com/static/departments/boc/ pdf/2007_state_of_the_county.pdf.

Gwinnett County, Georgia, 2008, 08 state of the county: Gwinnett County, 4 p., accessed January 31, 2014, at http://www.gwinnettcounty.com/static/departments/boc/ pdf/2008_SOC_handout.pdf.

Gwinnett County, Georgia, 2009, Gwinnett County state of the county, January 2009: Gwinnett County, 4 p., accessed January 31, 2014, at http://www.gwinnettcounty.com/static/ departments/boc/pdf/09_SOC_Handout.pdf.

Gwinnett County, Georgia, 2010, Gwinnett County state of the county, February 2010: Gwinnett County, 2 p., accessed January 31, 2014, at http://www.gwinnettcounty.com/static/ departments/boc/pdf/2010_SOC_Handout.pdf.

Gwinnett County, Georgia, 2012, State of the county, February 2012: Gwinnett County, 2 p., accessed January 31, 2014, at http://www.gwinnettcounty.com/static/pdf/2012_SOC_ Handout.pdf.

Gwinnett County, Georgia, 2013, State of the county, January 2013: Gwinnett County, 2 p., accessed January 31, 2014, at http://www.gwinnettcounty.com/static/departments/boc/ pdf/2013_SOC_Handout_FINAL.PDF.
Gwinnett County, Georgia, 2014, State of the county, January 2014: Gwinnett County, 2 p., accessed January 31, 2014, at http://www.gwinnettcounty.com/static/departments/boc/ pdf/2014_SOC_Handout.pdf.

Gwinnett County, Georgia, 2015, 2015 state of the county: Gwinnett County, 2 p., accessed January 17, 2017, at https://www.gwinnettcounty.com/static/departments/boc/ pdf/State_of_the_County_2015_WEB.pdf.

Gwinnett County, Georgia, 2016, State of the county 2016: Gwinnett County, 2 p., accessed January 17, 2017, at https://www.gwinnettcounty.com/static/departments/boc/ pdf/State_of_the_County_2016_Handout.pdf.

Helsel, D.R., and Hirsch, R.M., 1992, Statistical methods in water resources-Studies in Environmental Science 49: Amsterdam, The Netherlands, Elsevier Science, 529 p.

Hirsch, R.M., Alexander, R.B., and Smith, R.A., 1991, Selection of methods for the detection and estimation of trends in water quality: Water Resources Research, v. 27, no. 5 , p. $803-813$.

Hirsch, R.M., Moyer, D.L., and Archfield, S.A., 2010, Weighted regressions on time, discharge, and season (WRTDS), with an application to Chesapeake Bay river inputs: Journal of the American Water Resources Association, v. 46, no. 5, p. 857-880, accessed January 17, 2017, at https://doi.org/ 10.1111/j.1752-1688.2010.00482.x.

Hollis, G.E., 1975, The effect of urbanization on floods of different recurrence interval: Water Resources Research, v. 11 , no. 3 , p. $431-435$.

Horowitz, A.J., 2003, An evaluation of sediment rating curves for estimating suspended sediment concentrations for subsequent flux calculations: Hydrological Processes, v. 17, no. 17 , p. $3387-3409$.

Johnson, A.H., 1979, Estimating solute transport in streams from grab samples: Water Resources Research, v. 15, no. 5, p. $1224-1228$.

Joiner, J.K., Aulenbach, B.T., Landers, M.N., 2014, Watershed characteristics and water-quality trends and loads in 12 watersheds in Gwinnett County, Georgia: U.S. Geological Survey Scientific Investigations Report 2014-5141, 79 p. [Also available at https://doi.org/10.3133/sir20145141.]

Kendall, M., 1938, A new measure of rank correlation: Biometrika, v. 30 , no. $1-2$, p. $81-93$, accessed January 17,2017 , at https://doi.org/10.1093/biomet/30.1-2.81.

Kirchner, James, 2001, Data analysis toolkit \#5-Uncertainty analysis and error propagation: Analysis of Environmental Data Course, University of California, Berkeley, Calif., 8 p., accessed January 17, 2017, at http://seismo.berkeley.edu/ kirchner/eps_120/Toolkits/Toolkit_05.pdf. 
Knott, J.M., Glysson, G.D., Malo, B.A., and Schroeder, L.J., 1993, Quality assurance plan for the collection and processing of sediment data by the U.S. Geological Survey, Water Resources Division: U.S. Geological Survey Open-File Report 92-499, 18 p. [Also available at http://pubs.er.usgs.gov/pubs/ofr/ofr92499.]

Landers, M.N., 2013, Total suspended solids concentrations and yields for water-quality monitoring stations in Gwinnett County, Georgia, 1996-2009: U.S. Geological Survey Open-File Report 2013-1145, 10 p., accessed July 21, 2014, at http://pubs.usgs.gov/of/2013/1145/.

Landers, M.N., Ankcorn, P.D., and McFadden, K.W., 2007, Watershed effects on streamflow quantity and quality in six watersheds of Gwinnett County, Georgia: U.S. Geological Survey Scientific Investigations Report 2007-5132, 62 p., accessed January 17, 2017, at http://pubs.usgs.gov/sir/ 2007/5132/.

Larson, S.J., Capel, P.D., Goolsby, D.A., Zaugg, S.D., and Sandstrom, M.W., 1995, Relations between pesticide use and riverine flux in the Mississippi River basin: Chemosphere, v. 31, no. 5, p. 3305-3321.

Leopold, L.B., 1968, Hydrology for urban land planningA guidebook on the hydrologic effects of land use:

U.S. Geological Survey Circular 554, 18 p.

Likens, G.E., Bormann, F.H., Pierce, R.S., Eaton, J.S., and Johnson, N.M., 1977, Biogeochemistry of a forested ecosystem: New York, Springer-Verlag, 146 p.

Lim, K.J., Engel, B.A., Tang, Zhenxu, Choi, Joongdae, Kim, K.-S., Muthukrishnan, Suresh, and Tripathy, Dibyajyoti, 2005, Automated web GIS based hydrograph analysis tool, WHAT: Journal of the American Water Resources Association, v. 41, no. 6, p. 1407-1416.

MacDonald, L.H., 2000, Evaluating and managing cumulative effects-Process and constraints: Environmental Management, v. 26, no. 3, p. 299-315.

McCrary, Matt, 2011, Effects of topography on North Georgia (Atlanta, GA), Severe weather and tornadoes: theweather prediction.com, accessed July 12, 2011, at http://www. theweatherprediction.com/weatherpapers/122/index.html.

Mote, T.L., Lacke, M.C., and Shepherd, J.M., 2007, Radar signatures of the urban effect on precipitation distribution: A case study for Atlanta, Georgia: Geophysical Research Letters, v. 34, L20710, accessed February 3, 2017, at https://doi.org/10.1029/2007GL031903.

National Oceanic and Atmospheric Administration, National Climatic Data Center, 2014, 1981-2010 U.S. climate normals, accessed May 1, 2014, at http://www.ncdc.noaa.gov/oa/ ncdc.html.
Nippgen, Fabian, McGlynn, B.L., Emanuel, R.E., and Vose, J.M., 2016, Watershed memory at the Coweeta Hydrologic Laboratory - The effect of past precipitation and storage on hydrologic response: Water Resources Research, v. 52, p. 1673-1695.

Ogden, F.L., Pradhan, N.R., Downer, C.W., and Zahner, J.A., 2011, Relative importance of impervious area, drainage density, width function, and subsurface storm drainage on flood runoff from an urbanized catchment: Water Resources Research, v. 47, 12 p.

Poff, N.L., Allan, J.D., Bain, M.B., Karr, J.R., Prestegaard, K.L., Richter, B.D., Sparks, R.E., and Stromberg, J.C., 1997, The natural flow regime-A paradigm for river conservation and restoration: BioScience, v. 47, no. 11, p. 769-784.

Preston, S.D., Bierman, V.J., Jr., and Silliman, S.E., 1989, An evaluation of methods for the estimation of tributary mass loads: Water Resources Research, v. 25, no. 6, p. 1379-1389.

Rantz, S.E., and others, 1982a, Measurement and computation of streamflow-Volume 1, Measurement of stage and discharge: U.S. Geological Survey Water-Supply Paper 2175, $313 \mathrm{p}$.

Rantz, S.E., and others, 1982b, Measurement and computation of streamflow-Volume 2, Computation of discharge: U.S. Geological Survey Water-Supply Paper 2175, 373 p.

Richter, B.D., Baumgartner, J.V., Powell, Jennifer, and Braun, D.P., 1996, A method for assessing hydrologic alteration within ecosystems: Conservation Biology, v. 10, no. 4, p. 1163-1174.

Richter, B.D., Baumgartner, Jeffery, Wigington, Robert, and Braun, David, 1997, How much water does a River need?: Freshwater Biology, v. 37, no. 1, p. 231-249.

Rose, Seth, and Peters, N.E., 2001, Effects of urbanization on streamflow in the Atlanta area (Georgia, USA) - A comparative hydrological approach: Hydrological Processes, v. 15, p. 1441-1457, accessed February 3, 2017, at https://doi.org/10.1002/hyp.218.

Runkel, R.L., Crawford, C.G., and Cohn, T.A., 2004, Load estimator (LOADEST) - A FORTRAN program for estimating constituent loads in streams and rivers: U.S. Geological Survey Techniques and Methods, book 4, chap. A5, 69 p.

Sanford, W.E., and Selnick, D.L., 2013, Estimation of evapotranspiration across the conterminous United States using a regression with climate and land-cover data: Journal of the American Resources Association, v. 49, no. 1, p. 217-230.

Semkin, R.G., Jefferies, D.S., and Clair, T.A., 1994, Hydrochemical methods and relationships for study of stream output from small catchments, Chap. 7 of Moldan, B., and Cerny, J., eds. Biogeochemistry of small catchmentsA tool for environmental research: New York, John Wiley and Sons, p. 163-187. 
Shem, Willis, and Shepherd, Marshall, 2009, On the impact of urbanization on summertime thunderstorms in AtlantaTwo numerical model case studies: Atmospheric Research, v. 92 , no. 2, p. 172-189, accessed February 3, 2017, at https://doi.org/10.1016/j.atmosres.2008.09.013.

Shreve, E.A., and Downs, A.C., 2005, Quality-assurance plan for the analysis of fluvial sediment by the U.S. Geological Survey Kentucky Water Science Center Sediment Laboratory: U.S. Geological Survey Open-File Report 2005-1230, 28 p.

Swirepik, J.L., Burns, I.C., Dyer, F.J., Neave, I.A., O’Brien, M.G., Pryde, G.M., and Thompson, R.M., 2016, Establishing environmental water requirements for the Murray-Darling basin, Australia's largest developed river system: River Research and Applications, v. 32, no. 6, p. 1153-1165.

U.S. Census Bureau, 2004, U.S. Census Bureau website accessed December 31, 2004, at http://www.census.gov.

U.S. Census Bureau, 2011, Population of Gwinnett County, Georgia, accessed January 18, 2017, at http://www.census.gov/ quickfacts/table/PST045215/13135.

U.S. Census Bureau, 2012, American community survey 5-year estimates of 2006-2010 block group data: U.S. Census web page, accessed January 26, 2014, at http://www.census.gov/geo/maps-data/data/tiger-data.html.

U.S. Census Bureau, 2014, American community survey 5-year estimates of 2009-2013 block group data: U.S. Census web page, accessed January 17, 2017, at http://www.census.gov/geo/maps-data/data/tiger-data.html.

U.S. Department of Agriculture, 1986, Urban hydrology for small watersheds ( $2 \mathrm{~d}$ ed.): U.S. Department of Agriculture, Natural Resources Conservation Service, Conservation Engineering Division, Technical Release 55 [TR-55], 164 p.

U.S. Drought Monitor, 2014, U.S. drought monitor classification scheme, drought severity classification: The National Drought Mitigation Center web page, accessed April 28, 2014, at http://droughtmonitor.unl.edu/AboutUs/ ClassificationScheme.aspx.

U.S. Drought Monitor, 2016, U.S. drought monitor statistics graph for Gwinnett County, Georgia: The National Drought Mitigation Center web page, accessed February 23, 2016, at http://droughtmonitor.unl.edu/MapsAndData/Graph.aspx.

U.S. Environmental Protection Agency, 1971, Method 365.2Phosphorous, all forms (colorometric, ascorbic acid, single reagent): U.S. Environmental Protection Agency, 7 p.

U.S. Environmental Protection Agency, 1992, NPDES storm water sampling guidance document: U.S. Environmental Protection Agency, EPA 833-8-92-001, 123 p.
U.S. Environmental Protection Agency, 1993a, Method 353.2, Revision 2.0-Determination of nitrate-nitrite nitrogen by automated colorimetry: U.S. Environmental Protection Agency, $14 \mathrm{p}$.

U.S. Environmental Protection Agency, 1993b, Method 351.2, Revision 2.0 - Determination of total Kjeldahl nitrogen by semi-automated colorimetry: U.S. Environmental Protection Agency, 15 p.

U.S. Environmental Protection Agency, 1994, Method 200.8, Revision 5.4-Determination of trace elements in waters and wastes by inductively coupled plasma-mass spectrometry: U.S. Environmental Protection Agency, 57 p.

U.S. Environmental Protection Agency, 2000a, Criteria development guidance-Rivers and streams, in U.S. Environmental Protection Agency, Nutrient criteria technical guidance manual-Rivers and streams, EPA-822-B-00-002, accessed June 21, 2012, at http://water.epa.gov/scitech/swguidance/standards/ criteria/nutrients/rivers/index.cfm.

U.S. Environmental Protection Agency, 2000b, Overview of current total maximum daily load-TMDL—Program and regulations: U.S. Environmental Protection Agency, EPA 841-F-00-009, 4 p.

U.S. Environmental Protection Agency, 2010, Georgia water quality assessment report, Georgia cumulative TMDLs by pollutant: U.S. Environmental Protection Agency web page, accessed August 31, 2011, at http://ofmpub.epa.gov/ tmdl_waters10/attains_state.control?p_state $=\mathrm{GA}$.

U.S. Environmental Protection Agency, 2011, Secondary Drinking Water Regulations - Guidance for nuisance chemicals: U.S. Environmental Protection Agency 816-F-10-079, accessed October 26, 2011, at http://water.epa.gov/drink/ contaminants/secondarystandards.cfm.

U.S. Environmental Protection Agency, 2017, National recommended water quality criteria - aquatic life criteria table, accessed January 30, 2017, at https://www.epa.gov/ wqc/national-recommended-water-quality-criteria-aquaticlife-criteria-table.

U.S. Geological Survey, 2006, Collection of water samples (ver. 2.0): U.S. Geological Survey Techniques of WaterResources Investigations, book 9, chap. A4, September 2006, accessed July 21, 2014, at http://pubs.water.usgs.gov/twri9A4/.

U.S. Geological Survey, 2014, Geologic units in Gwinnett County, Georgia: U.S. Geological Survey mineral resources online spatial data, accessed May 16, 2014, at http://mrdata. usgs.gov/geology/state/fips-unit.php?code $=\mathrm{f} 13135$.

U.S. Geological Survey, 2016, National Water Information System-Web interface, accessed April, 2016, at https://doi.org/10.5066/F7P55KJN. 
Veilleux, A.G., Cohn, T.A., Flynn, K.M., Mason, R.R., and Hummel, P.R., 2014, PeakFQ Version 7.01, Flood frequency analysis based on Bulletin 17B and recommendations of the Advisory Committee on Water (ACWI) Subcommittee on Hydrology ( $\mathrm{SOH})$ Hydrologic Frequency Work Group (HFAWG), accessed March 18, 2016, at http://water.usgs.gov/ software/PeakFQ/.

Wagner, R.J., Boulger, R.W., Jr., Oblinger, C.J., and Smith, B.A., 2006, Guidelines and standard procedures for continuous water-quality monitors - Station operation, record computation, and data reporting: U.S. Geological Survey Techniques and Methods 1-D3, 51 p., 8 attachments.

Wilde, F.D., ed., 2004, Cleaning of equipment for water sampling (ver. 2.0): U.S. Geological Survey Techniques of Water-Resources Investigations, book 9, chap. A3, April 2004, accessed July 21, 2014, at http://pubs.water. usgs.gov/twri9A3/.
Wilde, F.D., Radtke, D.B., Gibs, Jacob, and Iwatsubo, R.T., eds., 2004 with updates through 2009, Processing of water samples (ver. 2.2): U.S. Geological Survey Techniques of Water-Resources Investigations, book 9, chap. A5, April 2004, accessed July 21, 2014, at http://pubs.water. usgs.gov/twri9A5/.

Yochum, S.E., 2000, A revised load estimation procedure for the Susquehanna, Potomac, Patuxent, and Choptank Rivers: U.S. Geological Survey Water-Resources Investigations, Report 00-4156, 49 p. 
Manuscript approved February 8, 2017

Prepared by the USGS Science Publishing Network Reston Publishing Service Center Edited by Kay P. Naugle Illustrations and layout by Caryl J. Wipperfurth

For additional information regarding this publication, please contact:

Director, South Atlantic Water Science Center

U.S. Geological Survey

720 Gracern Road

Stephenson Center, Suite 129

Columbia, SC 29210

(803) 750-6100

Or visit the South Atlantic Water Science Center website at

http://www.usgs.gov/water/southatlantic/ 
